\title{
LINHAS DIRETRIZES DA OCDE PARA AS EMPRESAS MULTINACIONAIS E SUA IMPLEMENTAÇÃO NO BRASIL
}

\begin{abstract}
Dissertação de Mestrado apresentada ao Departamento de Direito Internacional e Comparado da Faculdade de Direito da Universidade de São Paulo, como requisito parcial para obtenção do Título de Mestre em Direito Internacional, sob a orientação do Professor Doutor Pedro Bohomoletz de Abreu Dallari.
\end{abstract}

Universidade de São Paulo

Faculdade de Direito

São Paulo, 2012 
BANCA EXAMINADORA 


\section{AGRADECIMENTOS}

Agradeço ao meu Orientador. Prof. Dr. Pedro Bohomoletz de Abreu Dallari, e aos docentes vocacionados, pelo trabalho dedicado; e aos meus amigos e familiares, que suportaram comigo as preocupações desta pesquisa. 


\section{RESUMO}

ALLE, Saulo Stefanone. Linhas diretrizes da OCDE para as empresas multinacionais e sua implementação no Brasil. 2012. 211 f. Mestrado (Direito Internacional) - Faculdade de Direito da Universidade de São Paulo - FDUSP, São Paulo, 2013.

Este estudo visa analisar a implementação, no Brasil, das Linhas Diretrizes da OCDE para as Empresas Multinacionais, documento que integra a Declaração sobre o Investimento Internacional e as Empresas Multinacionais. De acordo com os termos estabelecidos nessa Declaração, os Estados devem promover essas Linhas Diretrizes, bem como instalar um Ponto de Contato Nacional (PCN) - mecanismo criado para consolidar os padrões de conduta e para receber reclamações atinentes à violação de seus termos por empresas multinacionais. A observância aos termos da Declaração é obrigatória para os Estadosmembros da Organização para Cooperação e Desenvolvimento Econômicos (OCDE) e condição para não membros participarem das atividades do Comitê de Investimentos situação na qual o Brasil se inclui. $\mathrm{O}$ ato internacional brasileiro de adesão à Declaração não se submeteu ao crivo parlamentar a que alude o artigo 49, inciso I, da Constituição Federal $(\mathrm{CF})$ e, além disso, as medidas adotadas internamente para implementar as Diretrizes - incluindo a instalação de PCN - foram ordenadas por uma "Portaria" -, que constitui ato do Ministério da Fazenda. Essas circunstâncias evidenciam como a cooperação e legitimidade fundada no consenso são base importante para que se promovam os direitos através das fronteiras sem desrespeitar a legislação brasileira, consoante este trabalho se propõe demonstrar.

Palavras-chave: Cooperação internacional. Atos de organizações internacionais. Padrões de conduta. Empresas multinacionais. OCDE. Direito brasileiro. 


\begin{abstract}
ALLE, Saulo Stefanone. The OECD Guidelines for Multinational Enterprises and their Implementation in Brazil. 2012. 211 f. Master's Degree (International Law) - Faculdade de Direito da Universidade de São Paulo - FDUSP, São Paulo, 2013.

This study analyses the implementation in Brazil of the OECD Guidelines for Multinational Enterprises, which constitute an integral part of the Declaration on International Investment and Multinational Enterprises. In accordance with the terms of the Declaration on International Investment and Multinational Enterprises, the states are to promote the Guidelines and install a National Point of Contact (NCP), the mechanism created to consolidate the Guidelines and receive complaints against the violation of their terms by multinational companies. Compliance with the terms of the Declaration is mandatory for the OECD member countries and the condition for non-members to participate in the activities of the Investment Committee like in the case of Brazil. The Brazilian international subscription act to the Declaration was not submitted to the approval of the parliament as per article 49, I of the Federal Constitution; in addition, the measures adopted internally to implement the Guidelines and install the NCP were ordered by "Decree"-an act within the competence of the Ministry. These circumstances show how cooperation and legitimacy founded on consensus are an important basis for the promotion of rights across borders without infringing Brazilian Law. This is what the present study proposes to discuss.
\end{abstract}

Key-words: International Cooperation. International organization acts. Standards of conduct. Multinational enterprises. OECD. Brazilian law. 


\section{RÉSUMÉ}

ALLE, Saulo Stefanone. Les principes directeurs de l'OCDE à l'intention des entreprises multinationales et leur application au Brésil. 2012. 211 p. Master (Droit International) Faculdade de Direito da Universidade de São Paulo - FDUSP, São Paulo, 2013.

Cette étude examine la mise en œuvre au Brésil des Principes Directeurs de l'OCDE à l'Intention des Entreprises Multinationales document faisant partie intégrante de la Déclaration sur l'investissement international et les entreprises multinationales. Selon les termes de la Déclaration sur l'investissement international et les entreprises multinationales, les états se doivent de promouvoir les principes directeurs et d'établir un Point de Contact National (PCN), mécanisme mis en place pour consolider les normes de conduite et recevoir les plaintes contre la violation de ses termes par les entreprises multinationales. L'application des termes de la Déclaration est obligatoire pour les états membres de l'OCDE et une condition pour la participation des états non membres aux activités du Comité de l'investissement, comme dans le cas du Brésil, par exemple. L'acte international brésilien d'adhésion à la Déclaration n'est pas passé au crible du parlement, conformément à l'article 49, I de la Constitution Fédérale, c'est, par ailleurs, sur ordonnance que les mesures ont été prises en interne en vue de la mise en œuvre des principes directeurs et de l'installation du PCN, un acte relevant du ministère. Ces circonstances montrent combien la coopération et la légitimité fondée sur un consensus sont le fondement de la promotion des droits à travers les frontières sans enfreinte à la législation brésilienne. Voilà ce que le présent travail se propose de démontrer.

Mots-clé: Coopération internationale. Actes d'organisations internationales. Normes de conduite. Entreprises multinationales. OCDE. Droit brésilien. 


\section{SUMÁRIO}

INTRODUÇÃ̃O

\section{CAPÍTULO 1 - A ORGANIZAÇÃO PARA COOPERAÇÃO E}

DESENVOLVIMENTO ECONÔMICOS ..................................................................................... 17

1.1 A Denominaçã̃o em Língua Portuguesa .............................................................................. 17

1.2 Apresentação Histórica da OCDE .......................................................................................... 19

1.2.1 Momento 1: Antes da Segunda Guerra Mundial ........................................................... 19

1.2.2 Momento 2: Após a Segunda Guerra Mundial ............................................................... 21

1.2.2.1 A Criação da OECE ........................................................................................................ 23

1.2.2.2 A Criação da OCDE e seu Mandato ……………………................................................. 25

1.3 A OCDE em Contexto: Aspectos Gerais sobre a Teoria das Organizações

Internacionais ..................................................................................................................... 26

1.4 Aspectos Práticos da Constituição e da Sucessão das Organizações Internacionais:

o Caso da OCDE ................................................................................................................................. 31

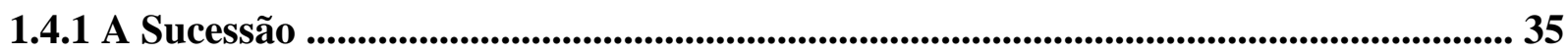

1.5 A Sistemática de Atuação da OCDE .............................................................................. 36

1.6 Estrutura da OCDE: Resolução Revisada do Conselho sobre uma Nova

Estrutura de Governança para a Organização ................................................................... 39

CAPÍTULO 2 - OS ATOS DA OCDE E O DIREITO BRASILEIRO ............................... 41

2.1 Atos das Organizações Internacionais no Contexto Cooperativo ................................... 41

2.2 Poderes das Organizações Internacionais ............................................................................. 46 
2.3 Os Atos da OCDE e sua Tipologia

2.4 A OECD perante o Direito Brasileiro: Personalidade e Capacidade para a Prática de Atos 57

2.5 Os Atos de Organização Internacional no Direito Brasileiro 60

\section{CAPÍTULO 3 - RELAÇÕES BRASIL-OCDE E VINCULAÇÃO ÀS LINHAS}

DIRETRIZES DA OCDE PARA AS EMPRESAS MULTINACIONAIS ........................ 65

3.1 Participação de Não Membros nas Atividades da OCDE .............................................. 65

3.2 A Regulamentação Atual: Resolution of the Council Concerning the

Participation of Non-Members in the Work of Subsidiary Bodies of the

Organization (C(2004)132/FINAL) 69

3.3 Do Estabelecimento de Relações entre A OCDE e o Brasil, um Não Membro 72

3.4 A Resolução da OCDE sobre Ampliação e Engajamento e o Contexto da

Participação Brasileira 76

CAPÍTULO 4 - DECLARAÇÃO SOBRE INVESTIMENTO INTERNACIONAL E AS EMPRESAS MULTINACIONAIS E O SEU ANEXO COM AS DIRETRIZES

DA OCDE PARA AS EMPRESAS MULTINACIONAIS 83

4.1 O Mandato do Comitê de Investimentos: a Declaração sobre o Investimento Internacional e as Empresas Multinacionais e o seu Anexo com as Diretrizes da OCDE para as Empresas Multinacionais 83

4.2 A Organização da Declaração e suas Emendas de Revisão (1976-2011) 84

4.3 As Revisões Periódicas das Linhas Diretrizes perante o Direito Brasileiro 86

4.4 O Conteúdo das Linhas Diretrizes da OCDE para as Empresas Multinacionais como Parte da Declaração 


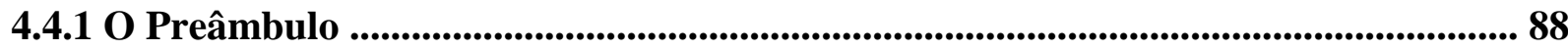

4.4.2 Conceitos e Princípios …………………....................................................................................... 90

4.4.3 Políticas Gerais …................................................................................................... 92

4.4.4 Divulgação ........................................................................................................................ 93

4.4.5 Direitos Humanos ............................................................................................................................... 94

4.4.6 Emprego e Relações Industriais ............................................................................................. 95

4.4.7 Meio Ambiente ........................................................................................................................ 95

4.4.8 Combate ao Suborno ...................................................................................................................... 96

4.4.9 Interesses dos Consumidores ............................................................................................... 97

4.4.10 Ciência e Tecnologia ................................................................................................................... 98

4.4.11 Concorrência ................................................................................................................................... 99

4.4.12 Fiscalidade ...............................................................................................................99

4.5 Natureza Jurídica das Linhas Diretrizes e o "Soft Law” '................................................. 100

CAPÍTULO 5 - O PONTO DE CONTATO NACIONAL (PCN) ....................................... 105

5.1 O Processo de Vinculação Brasileira à Declaração sobre o Investimento

Internacional e as Empresas Multinacionais e as Diretrizes da OCDE para as

Empresas Multinacionais no Brasil ........................................................................................... 105

5.2 Mecanismo de Controle: o Ponto de Contato Nacional ...................................................... 107

5.2.1 Modalidades Institucionais ................................................................................................ 110

5.2.2 Informação e Promoção ......................................................................................................... 111

5.2.3 Implementação em Circunstâncias Específicas ............................................................... 111

5.2.4 Elaboração de Relatórios ....................................................................................................... 111

5.3 Empresas Multinacionais: a Sujeição às Linhas Diretrizes .............................................. 112

5.4 A Prática das Diretrizes e do PCN ……………………......................................................... 115

5.5 Os Casos do PCN Brasileiro ……………...................................................................................... 117 
CAPÍTULO 6 - O PROBLEMA DAS DIRETRIZES NO BRASIL ................................. 122

6.1 Análise: a Implantação das Diretrizes e do PCN no Brasil ........................................ 122

6.2 O Problema das Diretrizes e do PCN perante o Direito Brasileiro .............................. 128

6.3 Consensualidade: o Conteúdo das Linhas Diretrizes .............................................. 130

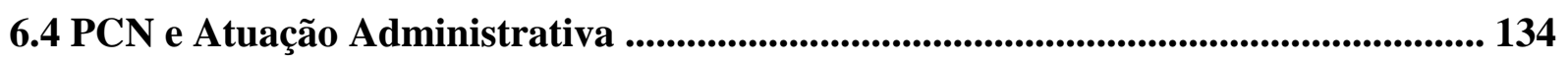

6.5 Diretrizes: Efetividade vs. Autoridade ................................................................. 137

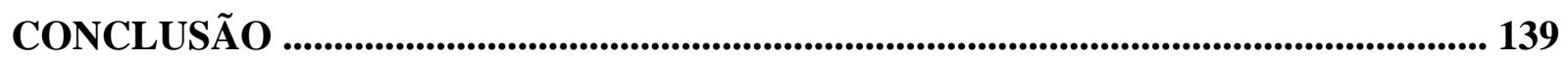

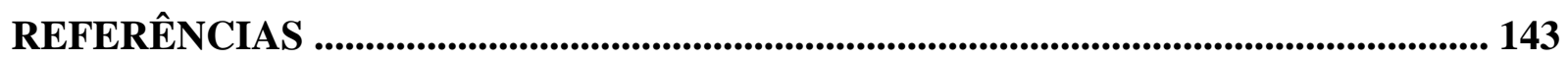

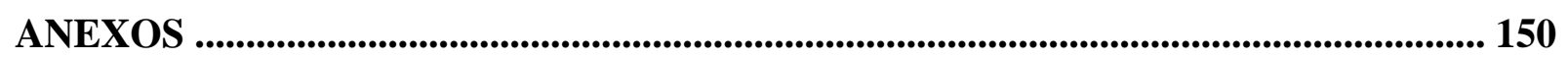




\section{INTRODUÇÃO}

As questões concernentes à implementação, no Brasil, das Linhas Diretrizes da OCDE para as Empresas Multinacionais evidenciam a necessidade de atenção a uma nova fronteira entre o direito interno e as normas jurídicas internacionais. Até agora os estudos alusivos à relação entre o direito interno e o Direito Internacional Público partiram - e não foram muito além - da mais clássica das fontes de direito internacional: os tratados.

O tema das relações entre o direito interno brasileiro e o Direito Internacional Público consolidou-se na jurisprudência, no que tange aos tratados internacionais; contudo, a integração entre o direito interno e o direito internacional, quando o assunto é atos de organização internacional e atividade de cooperação internacional, ainda depende do tratamento dispensado aos tratados. Nesse contexto, há os casos envolvendo a Corte Interamericana de Direitos Humanos, as Resoluções da Organização das Nações Unidas (ONU) e o Mercado Comum do Sul (Mercosul); mas a atipicidade de determinadas relações estabelecidas com a Organização para Cooperação e Desenvolvimento Econômicos $(\mathrm{OCDE})^{1}$ evidencia que o assunto deve avançar e assumir certa autonomia porque muitas relações de suma importância atinentes a direito internacional podem ser estabelecidas de forma saudável e compatível, em termos materiais, com objetivos constitucionalmente definidos. Ademais, entende-se que as relações havidas especialmente no campo cooperativo demandam um tratamento muito específico - dado que se intensificam no âmbito internacional, com grande velocidade, em face da demanda criada por assuntos que dependem da atuação orquestrada pelos Estados. Essa realidade, de modo especial, exige revisão dos paradigmas da relação entre o direito internacional e o direito interno brasileiro.

As Linhas Diretrizes da OCDE para as Empresas Multinacionais, por sua vez, constituem padrões de conduta direcionados a empresas privadas, e que integram um sistema gerido em uma das mais prestigiadas organizações internacionais, a OCDE. As Diretrizes fazem parte da Declaração sobre o Investimento Internacional e as Empresas Multinacionais, documento que os países-membros da OCDE têm o compromisso de promover em seu território.

\footnotetext{
${ }^{1}$ Ver, no Capítulo 1, item 1.1, a respeito do emprego dessa nomenclatura no Brasil, tradução dos textos oficiais em francês, l'Organisation de Coopération et de Développement Économiques (OCDE); e em inglês, Organisation for Economic Co-operation and Development (OECD).
} 
A ideia das Diretrizes pertence a um contexto em que atores internacionais - as empresas multinacionais - demandam um tratamento jurídico uniforme no plano internacional. Essas empresas estabelecem relações múltiplas, com ordenamentos jurídicos e realidades políticas diversas; além disso, detêm pujança econômica apta a influenciar de modo relevante a realidade de muitos dos Estados em que se instalam. Daí pensar-se que a criação de normas que permitissem uma homogeneização dessas relações, no que tange a fomentar o aprimoramento da qualidade das relações entre as sociedades locais e essas empresas, devesse ter lugar. Entretanto, essa iniciativa é mais bem conduzida partindo-se de uma organização internacional com condições de imprimir legitimidade a essas normas e de promover sua efetividade.

Essa organização internacional a que se alude neste estudo - a OCDE -, embora detentora de uma história e de um método que lhe conferem prestígio e reconhecido respeito - traduzindo-se em eficácia na busca de seus objetivos -, reunia um grupo muito seleto e restrito de Estados. Percebe-se de suas ações e decisões nas últimas décadas que a necessidade de ampliar sua atuação era indissociável do cumprimento de sua finalidade - até porque o mundo muda.

A herança histórica da Organização Europeia de Cooperação Econômica (OECE) é latente e determinante na natureza e no modus operandi da OCDE dos dias atuais. É com base nos princípios herdados que se pode compreender com maior profundidade os mecanismos adotados na atuação corriqueira da OCDE e, especialmente, nos instrumentos de formação e efetivação das Diretrizes. No entanto, a transformação da Organização Europeia em uma Organização para Cooperação e Desenvolvimento Econômicos global, embora tenha incorporado muito do know-how, pretendeu ampliar sua esfera de atuação. Da Europa para o mundo, a OCDE precisou reformular suas políticas e regras com vistas à abertura. Instituiu formas de participação que admitem os não membros - categoria em que o Brasil se enquadra no Comitê de Investimentos (responsável pelas Diretrizes).

O Brasil - não membro - foi admitido como observador no Comitê de Investimentos e aderiu à Declaração, assumindo o compromisso de implantar as Diretrizes. Essa relação estabelecida pelo País com o objetivo de aproximar-se da OCDE ainda sem um direcionamento político muito definido e coeso - originou uma série de implicações. Veja-se, por exemplo, que referida adesão significou um dado compromisso de observância de algumas decisões da OCDE, adotadas por seu Conselho, porque fazem parte do contexto do Comitê de Investimentos e da Declaração sobre Investimento 
Internacional e Empresas Multinacionais. Citem-se, a esse respeito, as mais recentes alterações incorporadas por uma Resolução do Conselho da OCDE, de maio de 2011, ao conteúdo das Diretrizes.

Além disso, o Brasil - ao aderir ao documento mencionado - comprometeu-se com uma decisão do Conselho da OCDE, de força vinculante aos membros da organização, que criou a figura do Ponto de Contato Nacional (PCN). Esse mecanismo deveria ser instalado, individualmente, pelos países aderentes para fiscalização e promoção da observância das Diretrizes. No Brasil, o PCN é um órgão instalado no Ministério da Fazenda, mas de colaboração interministerial. Na prática, o PCN deve adotar medidas de promoção das Diretrizes e servir como agente de resolução de questões que podem ser iniciadas por reclamação dirigida a um PCN, em face da conduta de uma empresa; nesse caso, um procedimento será instaurado, com apuração prévia, tentativa de composição das partes e emissão de um relatório final, dando publicidade ao problema e às posturas adotadas pela empresa reclamada.

Esse sistema expressa de forma muito aguda os princípios da OCDE, desde a definição das Diretrizes até a operacionalização do PCN. Nele, estão evidentes as preferências pelas decisões e soluções consensuais e da cobrança política pela efetivação dos compromissos assumidos.

A sistemática em referência mostra-se bastante apropriada para o caso. $\mathrm{O}$ tratamento das empresas multinacionais encontrou um meio muito eficaz e inteligente na adoção de códigos de conduta que evidenciam - até pelo que se observa da prática do PCN - certa legitimidade por expressarem valores consensualmente aceitos. Advirta-se, contudo, que não se está falando de nenhum tipo de vinculação legalista a determinado comportamento, mas exatamente à definição de altos padrões de observância da ordem jurídica interna.

A adesão à Declaração, com o consequente compromisso de implementar as Diretrizes que ela contém, assim como a condição de observador, assumida pelo Brasil, não estão, todavia, escudados em atos que tenham sido objeto de manifestação congressual, a teor do disposto no artigo 49, inciso I, da Constituição Federal. A adesão à Declaração, ao contrário, deu-se por mera troca de notas, e a implantação do PCN e das Diretrizes encontra respaldo apenas em uma "Portaria" do Ministério da Fazenda e uma tradução extraoficial das Diretrizes como instrumentos jurídicos de formalização dos compromissos - que afetam o Poder Público e os particulares - em ordem interna. 
No caso em foco, deve-se destacar que a relação estabelecida com a OCDE não é amparada pela adesão formal à sua Convenção, pelo Brasil. Não há manifestação congressual e recepção de normas nos moldes constitucionais, no que tange tanto à Convenção da OCDE como aos compromissos assumidos pelo Brasil perante essa Organização.

Ressalte-se, contudo, que as relações com a OCDE são de grande importância e que o Brasil tem posto em prática os compromissos assumidos sobre promoção e implementação das Diretrizes. A sociedade civil e as empresas, por sua vez, têm demonstrado respeito ao sistema do PCN (mecanismo do sistema das Diretrizes); várias questões envolvendo grandes empresas e as condutas previstas nas Diretrizes foram levadas ao PCN, sendo possível notar uma recepção positiva pelas entidades da sociedade civil e também das empresas, além de resultados úteis para a sociedade.

No Relatório Anual de 2010, o Brasil relata doze casos tratados pelo Ponto de Contato Nacional, relativos a denúncias de inobservância das Diretrizes pelas empresas instaladas no território nacional - um desses casos diz respeito a atividade desenvolvida em um país vizinho. Embora as informações não sejam todas de domínio público, já que parte do procedimento se dá de modo sigiloso, é possível afirmar que as questões envolvem empresas de grande porte, sempre em questões de especial relevância, notadamente relações com empregados e meio ambiente.

Infere-se que duas posturas podem ser adotadas, do ponto de vista jurídico: ou se aceita que a relação com a OCDE encontra respaldo na ordem interna, embora não se amolde à relação prevista pelo artigo 49, inciso I, da Constituição Federal, ou se admite que a relação e os compromissos assumidos são ilegítimos e inconstitucionais. A opção deve ser feita após a análise de alguns pontos, como a aplicação do princípio da cooperação (artigo 4º , inciso IX, da CF) e, sobretudo, a compreensão da nova realidade posta pelo direito internacional, diante dos desafios que se vão apresentando como relevantes.

Seja como for, o tratamento da implementação das Diretrizes no Brasil evidencia a necessidade de amadurecimento dessa nova possibilidade desenvolvida pelo direito internacional: a possibilidade da participação mais ativa das organizações internacionais como fontes da normatividade jurídica internacional e como adequada instância capaz de promover a organização cooperativa de determinadas relações havidas de forma transnacional. Essa questão expressa, portanto, uma nova fronteira do tema da integração entre o direito interno e o direito internacional. 
Nesse contexto, analisam-se as atipicidades do processo de implementação das Linhas Diretrizes no Brasil, avaliando-se qual fundamento constitucional legitima essas relações com a OCDE (estabelecidas pela aceitação da Declaração) e com as empresas multinacionais (pela promoção das Linhas Diretrizes e atuação do PCN). O trabalho, por sua vez, é estruturado em seis capítulos e desenvolvido centralmente com base na apreciação de documentos produzidos pela própria Organização, tanto relacionados ao seu funcionamento quanto à sistemática das Linhas Diretrizes, além do amparo da doutrina.

O primeiro capítulo dedica-se ao estudo da OCDE em si, em perspectiva histórica. Procura destacar os princípios de funcionamento da Organização, porque eles orientam e determinam a dinâmica das relações da OCDE com o Brasil. Além disso, esses princípios de funcionamento também definem a identidade da sistemática das Linhas Diretrizes, como se verá adiante. O segundo capítulo trata dos atos da OCDE, como atos de organização internacional. O interesse sobre esse assunto justifica-se, para este trabalho, do ponto de vista do direito brasileiro. Por esse motivo, o capítulo encerra-se abordando a relação entre o direito interno e os atos de organização internacional. Evidencia-se, já aqui, a importância do princípio cooperativo no contexto da implementação das Linhas Diretrizes no Brasil.

O terceiro capítulo examina as relações entre o Brasil e a OCDE, tanto sob uma análise das razões políticas e das tendências históricas, quanto sob um prisma jurídico. Destacam-se os documentos da OCDE que definem os parâmetros das relações com Estados não membros da Organização - condição do Brasil.

O quarto capítulo aborda objetivamente a Declaração sobre o investimento internacional e as empresas multinacionais, que contém as Linhas Diretrizes. Além da perspectiva histórica de revisões do documento, notadamente do ponto de vista do direito brasileiro, o capítulo dedica-se ao estudo do conteúdo das Linhas Diretrizes. O final é dedicado à natureza jurídica das Linhas Diretrizes.

O quinto capítulo trata do Ponto de Contato Nacional (PCN), que é o mecanismo de promoção das Linhas Diretrizes. Aborda, ainda, o Procedural Guidance (Guia de Procedimentos) que examina em pormenores a atuação dos PCNs e que decorre de uma decisão do Conselho da OCDE. O capítulo analisa, ainda, as questões relacionadas à sujeição às Linhas Diretrizes, pelas empresas, e sua função de harmonização de padrões internacionais com forte base no consenso.

O capítulo sexto aborda as questões relacionadas à implantação e funcionamento do PCN no Brasil. Esse capítulo resolve as questões pendentes, 
notadamente sobre a falta de procedimento formal de internalização das Linhas Diretrizes. Evidenciam-se, neste capítulo, o consenso e a cooperação como elementos de identidade das Linhas Diretrizes e, também, como legitimadores da sua implementação no Brasil.

Apresentam-se, por derradeiro, as conclusões alcançadas com a exegese do tema objeto de pesquisa. Há, ainda, os Anexos, que reúnem os principais documentos da OCDE abordados neste trabalho: a troca de notas entre o Brasil e a OCDE sobre a aceitação da Declaração e a participação brasileira como observador regular no Comitê de Investimentos - então denominado Comitê para Investimentos Internacionais e Empresas Multinacionais (Cime) -, a Declaração, a decisão do Conselho da OCDE, de maio de 2011, que definiu a nova redação das Diretrizes, além das decisões do Conselho da OCDE sobre sua estrutura de governança e ampliação, bem como sobre a participação de não membros. 


\section{CAPÍTULO 1}

\section{A ORGANIZAÇÃO PARA COOPERAÇÃO E DESENVOLVIMENTO ECONÔMICOS}

\subsection{A Denominação em Língua Portuguesa}

A questão da melhor nomenclatura a ser utilizada na língua portuguesa, para este trabalho, ao referir-se à OCDE, deve ser logo tratada, porque o nome é a primeira coisa que se define. Além disso, a inexistência de uma denominação oficial em idioma português, aliada à multiplicidade de variações de nomenclatura no português, inclusive em textos normativos oficiais brasileiros, indica que o assunto não é tão óbvio como se mostra à primeira vista, o que corrobora a necessidade de uma atenção prévia.

Os textos oficiais de criação da OCDE estão redigidos em inglês e em francês, com, respectivamente, as seguintes denominações à Organização: l'Organisation de Coopération et de Développement Économiques e Organisation for Economic Cooperation and Development. Vale mencionar que, embora Portugal seja um membro da OCDE, não há uma versão oficial do tratado de criação em idioma português - apesar da existência de documentos com tradução extraoficial para o português, elaborados pela própria OCDE. No texto das Diretrizes da OCDE para as Empresas Multinacionais, por exemplo, segundo a referida tradução extraoficial, a instituição é denominada Organização para a Cooperação e Desenvolvimento Económicos.

O Brasil, por sua vez, nas relações oficiais com a OCDE, produziu atos normativos (Decretos e Decretos Legislativos), nos quais empregou traduções variadas para a nomenclatura da organização internacional. Na Convenção sobre o Combate da Corrupção de Funcionários Públicos Estrangeiros em Transações Comerciais Internacionais (Decreto Legislativo $\mathrm{n}^{-}$125/2000 e Decreto $\mathrm{n}^{\underline{0}}$ 3.678/2000), utilizou Organização para a Cooperação Econômica e o Desenvolvimento, ao passo que no Decreto Legislativo n⿳ำ 33/1998 (Comitê do Carvão e do Aço) referiu-se a Organização para a Cooperação e o Desenvolvimento Econômico. Já na Resolução n⿳ำ 01/2007, do PCN brasileiro, instalado na estrutura do Ministério da Fazenda, a organização é referida como Organização para Cooperação e Desenvolvimento Econômico, expressão antes utilizada pela Portaria $\mathrm{n}^{\mathrm{o}}$ 92, de 12 de maio de 2003, que aprovou a criação do PCN. 
Sem grande aprofundamento linguístico, e mais em face de uma observação que atende à curiosidade despertada, pode-se concluir que a tradução mais literal do francês é apenas uma, mas do nome em inglês não. Do francês, a expressão l'Organisation de Coopération et de Développement Économiques aparentemente só poderia resultar em Organização para Cooperação e Desenvolvimento Econômicos; já do inglês, Organisation for Economic Co-operation and Development poderia ser traduzido como Organização para a Cooperação Econômica e Desenvolvimento ou Organização para Cooperação e Desenvolvimento Econômicos. Como se pode ver, a maior diferença, dessa perspectiva, residiria em saber a que o termo econômico se refere.

Do ponto de vista histórico, por sua vez, a tradução que se mostra mais sedimentada prefere OCDE e não OCED, e não leva o econômico ao plural, sem, contudo, evidenciar a que o termo econômico se refere, mas indicando fazer alusão ao desenvolvimento. E é nessa linha que a mencionada Portaria $n^{0}$ 92/2003 denota reportar-se à Organização, ao utilizar a nomenclatura Organização para Cooperação $e$ Desenvolvimento Econômico.

De fato, a primeira opção seria adotar diretamente a nomenclatura utilizada pela Portaria, como se tem feito, mas mostra-se correto - tanto pela observação linguística quanto pela tradução extraoficial proposta pela própria OCDE - relevar que o econômico diz respeito a ambos, ou seja, à cooperação e ao desenvolvimento. A opção mais adequada para o presente estudo científico inclina-se, portanto, para aquela que adiciona o " $s$ " ao econômico, corrigindo assim o uso corrente e oficial (no tocante à Portaria $n^{0}$ 92/2003) no sentido do que propõe a própria Organização, ainda que não oficialmente. Em face do exposto, este trabalho prefere empregar a nomenclatura Organização para Cooperação e Desenvolvimento Econômicos.

No que tange à Declaração sobre Investimento Internacional e Empresas Multinacionais (em inglês: Declaration on International Investment and Multinational Enterprises) e às Linhas Diretrizes da OCDE para as Empresas Multinacionais (em inglês: The OECD Guidelines for Multinational Enterprises), optou-se, no título, pela nomenclatura utilizada na tradução extraoficial pela própria OCDE (Linhas Diretrizes da OCDE para as Empresas Multinacionais). No entanto, durante o desenvolvimento do texto, por uma questão de objetividade e considerando a denominação empregada pela já referida Portaria $n^{0}$ 92/2003, será utilizada a expressão Diretrizes da OCDE para as Empresas Multinacionais. 
É relevante anotar que as expressões empregadas pela tradução extraoficial do documento, produzida pela própria OCDE, em português, equivalem às utilizadas pela Portaria em comento, exceto no tocante às Guidelines. Enquanto a OCDE utiliza a tradução Linhas Diretrizes - a mesma empregada no título do presente estudo, para facilitar eventuais pesquisas -, a Portaria nº 92/2003 refere-se apenas a Diretrizes. Linhas Diretrizes ou Diretrizes fazem alusão, portanto, ao mesmo documento.

Ao longo do trabalho, optou-se também por fazer menção abreviada aos documentos, referindo-se, eventualmente, apenas à Declaração ou às Diretrizes quando se quer reportar, respectivamente, à Declaração sobre Investimento Internacional e Empresas Multinacionais e às Linhas Diretrizes da OCDE para as Empresas Multinacionais.

\subsection{Apresentação Histórica da OCDE}

Um estudo que se proponha a analisar qualquer instrumento ou mecanismo ligado às atividades da OCDE passará, necessariamente, pela compreensão das circunstâncias históricas de sua concepção, em especial no que tange à conformação da Organização Europeia de Cooperação Econômica (OECE). É que sua identidade decorre deste aspecto: as realidades e necessidades responsáveis por plasmar a OECE explicam com mais propriedade as estruturas, o funcionamento e a finalidade da Organização.

Para melhor apreensão do que se propõe aqui apresentar como princípio geral de funcionamento da OCDE, em face de sua estruturação histórica, é adequado cindir a análise em dois momentos: o que antecede a Segunda Guerra Mundial e o que a sucede.

\subsubsection{Momento 1: Antes da Segunda Guerra Mundial}

O historiador Eric Hobsbawn escreve sobre o período de crise subsequente à Primeira Guerra Mundial, dando conta do comprometimento econômico que atingiu as mais diversas partes do globo após um primeiro momento de euforia:

Mas a Primeira Guerra foi seguida por um tipo de colapso verdadeiramente mundial, sentido pelo menos em todos os lugares em 
que homens e mulheres se envolviam ou faziam uso de transações impessoais de mercado ${ }^{2}$.

Os Estados Unidos, longe de serem imunes ao acontecimento, foram o epicentro, para utilizar o termo cunhado por Hobsbawn. E, a partir da América, a crise do capitalismo logo se ampliou, atingindo também o Velho Continente. Para dar uma medida do que se passava, o historiador exemplifica salientando que, "durante a Grande Depressão, até mesmo o fluxo internacional de capital pareceu secar. Entre 1927 e 1933, os empréstimos internacionais caíram mais de $90 \%$ "3.

Relacionada como motivo, mas também podendo ser compreendida como causa - um ciclo, talvez -, Hobsbawn menciona a autossuficiência perseguida por grandes economias como a americana e a britânica, no centro da estagnação da economia mundial ${ }^{4}$. Com isso, a onda de fechamento das economias se intensificou, afetando a economia mundial e sendo, por essa mesma onda, afetada. Pode-se dizer que a Grande Depressão teve o efeito de abalar a confiança internacional nas relações econômicas, concorrendo para um movimento de proteção das economias nacionais.

Dentre vários aspectos que poderiam acrescentar as matizes dessa crise que colaboraria para o cerramento das economias - junto com outros aspectos reunidos ao redor da eclosão da Guerra -, encontra-se a análise do setor agrícola. O economista Robert L. Heilbroner ${ }^{5}$, partindo de um ponto de vista americano, refere-se à fragilidade da propriedade agrícola, ao lembrar que o fator agrícola foi um dos elementos da Grande Depressão. Para ele, a prosperidade do setor, logo após a Primeira Grande Guerra, não se sustentou com a recuperação das economias europeias, gerando um quadro de saturada produção agrícola que acarretou um desequilíbrio sério nessa área tão estratégica ${ }^{6}$.

\footnotetext{
${ }^{2}$ HOBSBAWN, E. A era dos extremos: o breve século XX (1914-1991). São Paulo: Cia. das Letras, 1995. p. 91.

${ }^{3}$ Ibid., p. 93.

${ }^{4}$ Ibid., loc. cit.

${ }^{5}$ HEILBRONER, Robert. L. A formação da sociedade econômica. 5. ed. Rio de Janeiro: Guanabara, 1980. p. 186.

${ }^{6}$ Ibid., p. 192: ao analisar a situação da economia norte-americana, referida por Hobsbawn como epicentro da crise, Heilbroner escreve: "Na vulnerabilidade de uma economia atrelada a uma superestrutura financeira vacilante e especulativa, localizamos uma das razões da Grande Depressão - ou, mais especificamente, uma razão pela qual o colapso de Wall Street arrastou consigo tantas atividades empresariais. Mas estamos longe de esgotar as explicações para a própria depressão. Pois o colapso da Bolsa, no final das contas, poderia não ter sido pior que tantos outros desastres especulativos anteriores. Por que se dilatou e se converteu numa doença crônica e de profundas raízes? [...] Não há dúvida de que existia um desses setores preocupantes. Era o setor agrícola, especialmente a importantíssima área dos cereais. Durante toda a década de 1920, o agricultor foi o 'homem doente' da economia norte americana.". E, ainda, continua o economista: "De 1915 a
} 
Hobsbawn complementa os relatos e análises de Heilbroner, anotando que, diante da crise, os governos tiveram de adotar políticas sociais e protecionistas. Nas palavras do historiador:

[...] os governos não mais protegeram a agricultura, simplesmente com tarifas contra a competição estrangeira, embora, onde o tenham feito antes, erguessem barreiras tarifárias ainda mais altas. Durante a Depressão, passaram a subsidiá-la, assegurando preços agrícolas, comprando os excedentes ou pagando aos agricultores para não produzir, como nos EUA após $1933^{7}$.

Esse sistema protecionista contaminou, de fato, as economias, que mesmo depois da Guerra tiveram de insistir muito no vencimento desse antigo vício. O setor agrícola - o mesmo que tomamos como referência -, por exemplo, é uma prova viva da persistência dos sistemas protecionistas fortemente destacados no entreguerras. Assim, embora tenha sido uma das áreas de principal atuação da OECE, como será possível verificar adiante, permanecem os vestígios e debates recentes acerca do mencionado protecionismo agrícola.

\subsubsection{Momento 2: Após a Segunda Guerra Mundial}

Kissinger relata, no clássico Diplomacy, seu único encontro com o presidente Truman, dando conta de sua resposta à pergunta sobre como gostaria de ser lembrado:

Não hesitou: "Nós derrotamos completamente os nossos inimigos e fizemos com que se rendessem", ele observou. "Depois, ajudamos a se recuperarem, a tornarem-se democráticos, e a unirem-se novamente à comunidade das nações. Só os Estados Unidos poderiam ter feito isto."8.

De fato, sabe-se que o presidente Truman se refere ao projeto de reconstrução europeia do pós-Guerra, no qual se insere o Plano Marshall. Esse foi o plano de criação

\footnotetext{
1920, o agricultor prosperou porque a Primeira Guerra Mundial aumentou imensamente a demanda de seus produtos. [...] No entanto, quando a agricultura européia reiniciou sua produção, depois da guerra, as safras dos agricultores norte-americanos simplesmente saturaram o mercado." (HEILBRONER, Robert. L. A formação da sociedade econômica, p. 193).

${ }^{7}$ HOBSBAWN, E. A era dos extremos: o breve século XX (1914-1991), p. 99.

${ }^{8}$ KISSINGER, H. Diplomacy. 3. ed. Rio de Janeiro: Livraria Francisco Alves, 2001. p. 459.
} 
norte-americana para financiar a reconstrução europeia que, nas palavras de Hobsbawn, "assumiu mais a forma de verbas que de empréstimos".

Apenas a ajuda financeira não seria suficiente, já que o sucesso da reconstrução europeia dependeria de organização - era necessário o direcionamento racional dos recursos ou, em outros termos, havia a necessidade de gerenciamento dos recursos, com vistas a permitir o maior proveito. Importa lembrar adicionalmente que a herança da destruição causada pela Guerra e, sobretudo, das crises que colaboraram para a eclosão desta última, demandariam uma política de compromissos mútuos.

O problema todo não se resumia a reconstruir instalações e infraestrutura; era preciso também promover uma organização europeia receptiva à economia dinâmica, em que os investimentos pudessem efetivamente gerar riquezas. Para compreender melhor o problema a ser resolvido, convém lembrar-se da herança protecionista decorrente do enfraquecimento das economias e dos meios de produção, em face da destruição da Guerra, e também das estruturas viciadas que ainda permaneciam desde a Grande Depressão.

Enfraquecidas, acreditava-se que as economias europeias do pós-Guerra não poderiam enfrentar a concorrência de produtos estrangeiros, produzidos por estruturas preservadas e até aquecidas pela demanda da Guerra - portanto, que tinham vantagem competitiva. A saída natural e provável seria um incremento das políticas protecionistas o que a experiência anterior mostrou não ser salutar para a economia e para a paz mundial.

De qualquer forma, pretende-se evidenciar a crença de que o Plano Marshall, compreendido como o envio de recursos financeiros, por si só, não seria suficiente para a reconstrução das economias europeias. Entende-se ter ficado claro que seria fundamental a gerência estratégica do dinheiro do Plano, aliado ao direcionamento harmônico das políticas nacionais. Nesse contexto, a Organização Europeia de Cooperação Econômica foi criada em 1948:

L'Organisation Européenne de Coopération Économique (OECE) a été instituée le 16 avril 1948. Elle est issue du Plan Marshall et de la Conférence des Seize (Conférence de coopération économique européenne) qui a oeuvré pour l'établissement d'une organisation permanente chargée d'assurer la mise en oeuvre d'un programme de relèvement commun et, en particulier, de superviser la répartition de

\footnotetext{
${ }^{9}$ HOBSBAWN, E. A era dos extremos: o breve século XX (1914-1991), p. 237.
} 
l'aide. Le siège de l'Organisation a été fixé à Paris (France) au Château de la Muette ${ }^{10}$.

Os membros da Organização, inicialmente, foram dezoito: Áustria, Bélgica, Dinamarca, França, Grécia, Irlanda, Islândia, Itália, Luxemburgo, Noruega, Países-Baixos, Portugal, Reino Unido, Suécia, Suíça, Turquia e Alemanha Ocidental (pelas áreas sob administração dos Estados Unidos, Reino Unido e França), além do território autônomo de Trieste, posteriormente reincorporado pela Itália ${ }^{11}$.

\subsubsection{A Criação da OECE}

A criação da OECE visava, precipuamente, organizar e coordenar a distribuição dos recursos recebidos para a reconstrução ${ }^{12}$. Para essa primeira tarefa, além do Conselho da OECE, órgão de cúpula da qual participavam os representantes de cada um dos Estados, e cujas deliberações eram adotadas por unanimidade, havia comitês técnicos, que arbitravam sobre a aplicação do dinheiro em cada área.

Além das tarefas de organização estratégica da aplicação das verbas para a reconstrução da economia europeia, coube à OECE a função regulatória. Como salientado,

${ }^{10}$ Disponível em: <http://www.oecd.org/document/53/0,3343,fr_2649_201185_1876917_1_1_1_1,00.html〉. Acesso em: 6 abr. 2010. Tradução livre: “A Organização Europeia de Desenvolvimento Econômico (OEDE) foi instituída em 16 de abril de 1948. Ela era um instrumento do Plano Marshall e da Conferência de Seize (Conferência de cooperação econômica europeia) que foi aberta para o estabelecimento de uma organização permanente encarregada de assegurar a colocação em prática de um programa de recuperação comum e, em particular, de supervisionar a repartição da ajuda. A sede da Organização foi fixada em Paris (França) no Château de la Muette."

${ }^{11}$ Disponível em: <http://www.oecd.org>. Acesso em: 6 abr. 2010.

${ }^{12} \mathrm{Um}$ trabalho dedicado aos fundamentos históricos da OCDE demandaria especial profundidade. De qualquer maneira, não se pode furtar ao dever de mencionar brevemente que, como lembram Wendy Asbeek Brusse e Richard T. Griffiths, há um debate que opôs posições, algumas ditas tradicionalistas e outras revisionistas e, mais recentemente, pós-revisionistas a respeito do contexto de criação da OCDE. Os primeiros defendem que a criação da OCDE está relacionada diretamente com a contenção do comunismo; é uma posição bastante relacionável com o período da Guerra Fria. Os revisionistas - posição que emergiu nas décadas de 1960 e 1970 - também estabelecem grande relação, embora de modo diferente, entre o Plano Marshall e a Guerra Fria. Os pós-revisionistas, por sua vez, são mais reticentes a essa relação, preferindo a perspectiva de que o Plano Marshall e a criação da OCDE teriam decorrido, no contexto do Programa de Recuperação Europeia (ERP), do efetivo interesse de recuperação de economia europeia. De fato, Henry J. Bittermann, ao tratar do Banco Internacional para Reconstrução e Desenvolvimento (IBRD), reconhece que a expansão do comércio e do investimento seria importante para combater uma desaceleração na economia norte-americana no pós-Guerra e que, diante disso, era necessário enviar recursos para a reconstrução europeia (BRUSSE, Wendy Asbeek; GRIFFITHS, Richard T. Exploring the OEEC's past: the potentials and the sources. In: GRIFFITHS, Richard T. (Ed.). Explorations in OEEC history, OECD historical series. Paris: OECD, 1997, p. 15; BITTERMANN, Henry J. Negotiation of the Articles of Agreement of the International Bank for Reconstruction and Development. International Lawyers, v. 5, n. 1, 1979, p. 59). 
a Europa vinha de um período de grande fragilidade, o que provocou um movimento protecionista e de enfraquecimento tecnológico e científico de sua indústria. Nesse sentido, capacitar pessoal na área científica e tecnológica, além de promover mecanismos de liberalização do comércio - incluindo a superação das cotas de importação -, era de fundamental importância para os objetivos perseguidos pela Organização.

Por isso, em sua estruturação, a OECE contava com comitês especializados:

La structure opérationnelle de l'OECE consistait en quelque quinze comités techniques verticaux et cinq comités horizontaux chargés de domaines spécifiques: alimentation et agriculture, charbon, électricité, pétrole, sidérurgie, matières premières, équipement, métaux non ferreux, produits chimiques, bois, pâtes et papiers, textiles, transports maritimes et intérieurs, programmes, balance des paiements, échanges, paiements intra-européens et main-d'œuvre ${ }^{13}$.

Um dos resultados desse modo de atuação foi, logo nos primeiros anos, a criação de um sistema de pagamentos, absolutamente necessário para facilitar a circulação de riquezas dentro da Europa:

La création de l'Union européenne des paiements (UEP), en septembre 1950, sous les auspices de l'OECE, a représenté un autre acte remarquable de coopération. L'Union avait trois objectifs:

- lever l'obstacle de l'inconvertibilité des monnaies européennes,

- supprimer les restrictions quantitatives, et,

- mettre fin aux pratiques commerciales bilatérales ${ }^{14}$.

Sob essas circunstâncias, sobressaem não só os objetivos e princípios que pautam a Organização legatária (OCDE), mas também a metodologia de produção e difusão de conhecimentos e estratégias (think tank).

\footnotetext{
13 Disponível em: <http://www.oecd.org/.../0,3343,fr_2649_201185_1876917_1_1_1_1,00.html>. Acesso em: 6 abr. 2010. Tradução livre: "A estrutura operacional da OECE consistia de quinze comitês técnicos verticais e cinco comitês horizontais encarregados de questões específicas: alimentação e agricultura, carvão, eletricidade, petróleo, siderurgia, matérias-primas, equipamentos, metais não ferrosos, produtos químicos, florestas, papel e celulose, têxteis, transportes marítimos e interior, programas, balança de pagamentos, comércio, pagamentos intraeuropeus e mão de obra".

${ }^{14}$ Ibid. Tradução livre: “A criação da União Europeia de Pagamentos (UEP), em setembro de 1950, sob os auspícios da OECE, representou outro ato importante de cooperação. A União tinha três objetivos:
}

- levantar os obstáculos de inconvertibilidade das moedas europeias;

- $\quad$ suprimir as restrições quantitativas; e

- pôr fim às práticas comerciais bilaterais.” 
É pertinente salientar que a liberação de recursos sempre esteve ligada à necessidade de acompanhamento do emprego desses meios, bem como da cobrança pelos resultados efetivos. Essa demanda levou à instauração de um processo de acompanhamento ou fiscalização pelos demais membros da Organização, ou seja, de cobrança do cumprimento das metas traçadas por pressão dos pares. Só por esse sistema fiscalizatório, a aplicação dos recursos poderia ser tão eficaz quanto planejado.

E, por fim, resta lembrar que o fato de as decisões e conjunto normativo especialmente códigos de liberalização - decorrerem de decisões unânimes culminou com um sistema de elevada legitimidade, em que os membros tomam as normas como suas e, por isso mesmo, têm menos resistência em observá-las.

\subsubsection{A Criação da OCDE e seu Mandato}

A Organização Europeia de Cooperação Econômica (OECE) desempenhou suas funções, conforme previsto no ato constitutivo, até que, no final da década de 1960, já as havia esgotado. Com a economia europeia suficientemente reestruturada e capaz de caminhar por si própria, a estrutura e atuação da OECE, como inicialmente pensada, tornaram-se desnecessárias; além disso, os princípios perseguidos pela Organização já se haviam sedimentado na nova ordem europeia.

Ocorreu, assim, um caso típico de extinção de uma organização pelo cumprimento de sua finalidade. A causa que havia determinado a sua criação e a sua finalidade específica não se justificava mais - pelo menos no contexto europeu.

Como a fórmula adotada para a OECE alcançara excelentes resultados no contexto europeu, ela poderia ser aplicada para o resto do mundo. Seria necessário, para tanto, recriar a Organização, com vocação universal.

Daí que a Organização Europeia então criada para organizar e coordenar a distribuição dos recursos recebidos para a reconstrução europeia - arbitrada pelos Comitês Técnicos, que desempenhavam relevante função regulatória e de capacitação de pessoal na área científica e tecnológica, além de estabelecer mecanismos de liberalização do comércio - passou a ter uma finalidade muito mais ampla. As bases da nova OCDE esteiam-se em colaborar no desenvolvimento econômico mundial, sob a ideia de que desenvolvimento pressupõe cooperação.

O artigo primeiro da Convenção que criou a OCDE está assim redigido: 
L'Organisation de Coopération et de Développement Économiques (appelée ci-dessous l'«Organisation») a pour objectif de promouvoir des politiques visant:

a) à réaliser la plus forte expansion possible de l'économie et de l'emploi et une progression du niveau de vie dans les pays Membres, tout en maintenant la stabilité financière, et à contribuer ainsi au développement de l'économie mondiale;

b) à contribuer à une saine expansion économique dans les pays Membres, ainsi que non membres, en voie de développement économique;

c) à contribuer à l'expansion du commerce mondial sur une base multilatérale et non discriminatoire conformément aux obligations internationales ${ }^{15}$.

Com o legado da OECE, houve o incremento de sua vocação internacional, encaminhando o fomento ao liberalismo e o estímulo à cooperação entre os membros, em busca da estabilidade e do crescimento da economia mundial. Mantiveram-se, ainda, o método de trabalho e o conjunto de decisões normativas, como será possível ver adiante.

\subsection{A OCDE em Contexto: Aspectos Gerais sobre a Teoria das Organizações Internacionais}

Dentre tantas escolas teóricas, qual seria a mais adequada para uma análise sobre a OCDE como organização internacional? As organizações internacionais podem ser tratadas de pontos de vista diversos. Em apertada síntese, pode-se dizer que a abordagem funcionalista considera as organizações internacionais entes dotados de grande autonomia, produtores de direito, e não meros canais de convívio estatal. A ótica racionalista, por sua vez, aproxima-se da ótica funcionalista, envolvendo a ideia de desenvolvimento de um governo mundial, mas com estruturas mais rígidas (legalistas). Já o positivismo procura ser livre de valor, atendo-se à mera descrição sem juízo sobre a constituição de um governo mundial. Também atentos à realidade, e não às aspirações, os realistas diferem dos positivistas notadamente pelo foco nas relações de poder, mais do que sobre aspectos

\footnotetext{
${ }^{15}$ Disponível em: <http://www.oecd.org/document/44/0,3343,fr_2649_201185_1915884_1_1_1_1,00.html>. Acesso em: 6 abr. 2010). Tradução livre: “A Organização para Cooperação e Desenvolvimento Econômicos (doravante Organização) tem por objetivo a promoção de políticas visando: a) realizar a mais intensa expansão possível da economia e do emprego e uma progressão do nível de vida nos países-membros, a fim de manter a estabilidade financeira, e para contribuir assim com o desenvolvimento da economia mundial; b) contribuir com uma expansão econômica saudável nos países-membros, assim como nos não membros, em vista do desenvolvimento econômico; c) contribuir para a expansão do comércio mundial sobre uma base multilateral e não discriminatória conforme as obrigações internacionais."
} 
legais (positivistas) ${ }^{16}$. A escola crítica, de outra forma, procura combater as visões eurocentristas, que identifica nas demais escolas, considerando isso um vício histórico ao que antepõe a neutralidade ${ }^{17}$.

De fato, fosse outro o propósito deste trabalho, um capítulo inteiro poderia ser dedicado à análise da OCDE do ponto de vista de cada uma dessas escolas; contudo, como o objetivo aqui é proceder à análise das relações entre atos da Organização com o direito interno, e não aprofundar-se sobre a Organização em si, a sistematização detalhada tornase dispensável. Ater-se estritamente às posições de uma ou outra escola também não é mais útil a uma análise prática do que seria a um trabalho essencialmente teórico e didático. Nas palavras de José E. Alvarez:

[...] (the) description of major schools of thought is misleading to the extend it suggests hermetically self-contained alternatives. The competing frameworks elaborated above are best regarded as ideal types in the Weberian sense: generalized rubrics that might be useful for

${ }^{16}$ WHITE, N. D. The law of international organizations. Manchester: Manchester University Press, $1996 . \mathrm{p}$.
1-22: p. 3: "The functionalist approach adopted by international lawyers is characterized by a rejection of the
Idea that international organizations are simply 'vehicules for conference between the member nations'.
Instead, it is argued, they have a degree if autonomy. 'In particular, this school of thought advances the idea
that international organizations have the law-making capacity sometimes beyond that provided in their
constitutions. For example the UN Charter in Article 25 provides that decisions of the Security Council are
binding on member nations, in a different context under the 1957 Treaty of Rome and subsequent treaties,
legislation adopted by the Council of Minister and the Commission is directly binding on members of the
European Union. Whereas the formalist would argue that beyond this the United Nations or other
organizations do not have any greater law making capacity that literally found in their treaty make-up,
scholars like Professor Higgins argue that they do." p. 8: "According to the rationalist viewpoint, as international society evolves with the passage of time, it will increasingly move in the direction of world government. The difference between the rationalist approach and the functionalist approach can be seen in that rationalism predicts the development of international organizations towards world government whereas the functionalists see this as being achieved only if it is the final building block in the functional development of international organizations. In addition, rationalists see the development of international society moving towards more legal formalities and the rule of law - the idea that everybody in the system, government as well as governed, are subject to immutable and neutral legal principles. The functionalists, on the other hand, are keen to reduce the role of rigid legal structures which they see as getting in the way of international or regional agencies dealing effectively with common problems. In this respect the functionalists are nearer to the realist tradition reviewed below.

Rationalism must not be confused with positivism which advocates the systematic and scientific analysis of, in this case, international relations, in order to describe them and explain their working. Positivism, with its emphasis on a value-free, neutral approach to study, is not committed to the idea that international society is or ought to be developing towards world government."

p. 12: "In many ways the realists are like the positivists in that they are concerned with the world condition as it is rather than as it ought to be. Unlike the positivists, who in the main, concentrate on the legal situation, the realists are more concerned with what they see as the all-pervading struggle for power between States or blocs of States. World organizations are simply a reflection of this power struggle."

${ }^{17}$ ALVAREZ, José E. International organizations as law-makers. New York: Oxford University Press, 2006. p. 39. 
didactic purposes but that do not necessarily represent the views of any single scholar ${ }^{18}$.

Por isso, é relevante ter em mente a existência das escolas e da análise do fenômeno da organização internacional que se pode fazer com base nelas - até porque oferecem elementos bastante ricos e permitem uma dialética valiosa.

Mas, o que importa, centralmente, sobre organizações internacionais para a análise que se pretende desenvolver? Em primeiro lugar, é importante lembrar quais os elementos fundamentais caracterizadores de uma organização internacional, do ponto de vista jurídico. A esse propósito, a obra de Nguyen Quoc Dinh, Patrick Daillier e Alain Pellet lembra que a Convenção de Viena sobre o Direito dos Tratados (CVDT), de 1969, limita-se a relacionar a expressão "organização internacional" com "organização intergovernamental". Entretanto, os autores observam que uma definição proposta por Sir Gerald Fitzmaurice mereceria louros por conter os dois aspectos fundamentais na definição da organização internacional: fundamento convencional e natureza institucional ${ }^{19}$.

Outra valiosa contribuição prefere reforçar a tese de que todas as organizações internacionais têm em comum a personalidade jurídica. Assim se manifesta Mario Bettati:

Mais ce processus d'institutionnalisation se combine avec un autre caractère propre qui singularize les organisations internationales par rapport à d'autre êtres organiques voisins, c'est la personalité juridique international qui leur confère la qualité de sujet de droit international public (par. 2$)^{20}$.

A personalidade jurídica da organização internacional é, pois, um efeito de tratado - porque as organizações internacionais são constituídas por esse tipo de instrumento - que atinge terceiros não partes daquele tratado. Essa afetação à esfera

\footnotetext{
${ }^{18}$ ALVAREZ, José E. International organizations as law-maker, p. 45. Tradução livre: “[...] (a) descrição dada pelas principais escolas de pensamento é equivocada, na medida em que sugere realidades hermeticamente alternativas. Os quadros acima apresentados como concorrentes são considerados como os melhores tipos ideais no sentido weberiano: rubricas generalizadas que podem ser úteis para fins didáticos, mas que não representam necessariamente o parecer de qualquer estudioso."

${ }^{19}$ QUOC DINH, Nguyen; DAILLIER, Patrick; PELLET, Alain. Direito internacional público. 2. ed. Lisboa: Fundação Calouste Gulbenkian, 2003, p. 592, citando FITZMAURICE, Sir Gerald. A/CN.4/101, art. 3º Ann. C.D.I., 1956, v. II, p. 106.

${ }^{20}$ BETTATI, Mario. Création et personnalité juridique des organisations internationales. In: DUPUY, René Jean (Ed.). Manuel sur les organizations internationales. The Hague Academy of International Law Hage (Des Cours - Colloques, 87). Dordrecht: Martinus Nijhoff Publishers, 1998, p. 33. Tradução livre: "Mas esse processo de institucionalização é combinado com outra característica própria que singulariza as organizações internacionais em relação a outros entes semelhantes, é a personalidade jurídica internacional que lhes confere a qualidade de sujeito de direito internacional público (n. 2).”
} 
jurídica de terceiros é uma condição que denota contrariar uma regra geral de direito internacional e, inicialmente, foi objeto de discussões até sua atual sedimentação.

Zemanek discute o assunto em monografia de sua autoria. Após anotar que a “Opinião Consultiva da CIJ sobre Reparação por Lesões Sofridas pelas Nações Unidas"21 é comumente usada para imputar ao próprio ato constitutivo da Organização a atribuição não só de sua personalidade jurídica, mas de poderes e funções, levanta a questão dos efeitos dessas disposições voluntariamente admitidas pelos Estados celebrantes em relação aos Estados que não sejam parte. Zemanek lembra que um autor, Finn Seyersted, atribuiu ao direito costumeiro a verdadeira fonte da personalidade internacional das organizações. Zemanek esclarece que para Seyersted, em termos simplificados, as organizações intergovernamentais, desde que elas existem e porque elas existem, ipso facto, têm uma personalidade jurídica internacional lhes conferindo a inerente capacidade legal. A despeito de debates sobre o tema, Zemanek conclui que a prática tende a corroborar essa tese, quanto à capacidade jurídica, do que se pode extrair do Preâmbulo, artigo $2^{\underline{o}}, \S 1^{\underline{o}}$, alínea "j”, e artigo 6ำ da Convenção de Viena sobre o Direito dos Tratados, quando esses dispositivos são considerados em conjunto ${ }^{22}$.

É possível reconhecer, portanto, que a organização internacional é criada por um ato convencional, assumindo natureza institucional, dotada de personalidade jurídica. No tocante à personalidade jurídica, dispõe a Convenção relativa à OCDE, assinada em Paris, em 14 de dezembro de 1960:

Article 15

La reconstitution de l'Organisation Européenne de Coopération Économique prendra effet lors de l'entrée en vigueur de la Convention, et ses objectifs, organes, pouvoirs et nom seront dès lors ceux qui sont

\footnotetext{
${ }^{21}$ Tradução livre do original: “Advisory Opinion of the ICJ on Reparation for Injuries Suffered of the United Nations".

22 ZEMANEK, Karl. The legal foundations of the international system: general course on public international law. Recueil des Cours, v. 266, p. 88-90, 1997; p. 143: "For ages one writer, Finn Seyersted, has disputed this doctrine. To put it in simplified terms, he argues that intergovernmental organizations have, once they exist and because they exist, ipso facto objective international personality conferring inherent international legal capacity. Seyersted's submission implies that customary international law is the source of the legal personality of intergovernmental organizations, but he offers no positive proof of such a norm; his submission relies solely on the fact that, in practice, no intergovernmental organization has met with the objection that it lacked the necessary international capacity for its conduct or was transgressing express prohibitions in its statute."

Practice does tend rather towards Seyersted's submissions than towards the more restrictive doctrine. This is, at least, the conclusion that one may draw from the Preamble, Article 2, paragraph 1 (j), and Article 6 of the Vienna Convention on the Law of Treaties between States and International Organizations or between International Organizations (VCLTIO) of 1986 when they are considered together."
} 
prévus dans la Convention. La personnalité juridique que possède l'Organisation Européenne de Coopération Économique se continuera dans l'Organisation, mais les décisions, recommandations et résolutions de l'Organisation Européenne de Coopération Économique requièrent l'approbation du Conseil pour être applicables après l'entrée en vigueur de la présente Convention ${ }^{23}$.

Antes de tratar da constituição e, sobretudo, da sucessão - referida no artigo 15 supratranscrito -, faz-se oportuna uma breve reflexão sobre a finalidade de uma organização internacional.

Nesse sentido, respeitadas as posições mais específicas de escolas doutrinárias, mostra-se valiosa, mais uma vez, a proposição da obra de Quoc Dinh Nguyen, Patrick Daillier e Alain Pellet ${ }^{24}$ :

As crises e as tensões da sociedade internacional, ao demonstrarem as insuficiências da cooperação interestatal, obrigam a reforçar a rede das organizações e a confiar-lhes a solução de problemas cada vez mais agudos.

O trecho transcrito registra a constatação de que as organizações internacionais são instrumentos úteis ao tratamento de questões que afetam os Estados, mas que não poderiam ser eficientemente trabalhadas se não houvesse uma colaboração em certa medida mais intensa, com a formação de um único ente de atuação unívoca. Em razão disso, o trecho em comento é precedido da percepção de que "apesar de recuos temporários, a tendência geral é para uma coerência e uma eficácia acrescidas das organizações internacionais",25.

Em um cenário que propicie às organizações internacionais terem destaque, as relações entre seus atos e a ordem interna dos Estados intensificam-se, ao ponto de provocarem a reflexão sobre questões fundamentais - no caso deste estudo, a interação entre os atos de organizações internacionais e o direito interno brasileiro.

\footnotetext{
${ }^{23}$ Tradução livre: "Artigo 15. A reconstituição da Organização Europeia para a Cooperação Econômica produzirá efeitos com a entrada em vigor desta Convenção, e seus objetivos, órgãos, autoridade e nome serão aqueles previstos na Convenção. A personalidade jurídica da Organização Europeia para a Cooperação Econômica continuará na Organização, mas as decisões, recomendações e resoluções exigem a aprovação do Conselho para serem eficazes após a entrada em vigor da presente Convenção.".

${ }^{24}$ QUOC DINH, Nguyen; DAILLIER, Patrick; PELLET, Alain. Direito internacional público, p. 71.

${ }^{25}$ Ibid., p. 25.
} 


\subsection{Aspectos Práticos da Constituição e da Sucessão das Organizações Internacionais: o Caso da OCDE}

As organizações internacionais constituem um fenômeno complexo de direito internacional. As diversas conceituações que possam ser formuladas iniciam a sua compreensão, mas dificilmente abarcam todas as suas manifestações efetivas. É que, nesse campo, a pretensão de uma sistematização completa é tão mais frustrada pela realidade do que em qualquer campo do direito interno.

Essa conclusão sobre a complexidade do fenômeno, diante da insuficiência dos conceitos formulados, é de Mario Bettati, ao dizer que "eles são insuficientes para fazer frente ao fenômeno sob seus diferentes aspectos" ${ }^{26}$. O autor reconhece amplas possibilidades de formas, objetos e composições, mas admite que, em comum, toda organização internacional é dotada de personalidade jurídica de direito internacional público $^{27}$. Essa personalidade, por sua vez, decorre de um ato de direito internacional, isto é, de um tratado.

Seja como for, a organização internacional não é criação de um ato interno de um Estado, tampouco é ato individual e isolado de um Estado. A organização internacional, repise-se, decorre da concorrência de vontades de pessoas jurídicas de direito internacional, formalizada segundo as regras de direito internacional; portanto, criase por convergência de intenções, mediante celebração de ato escrito (tratado), praticado por pessoas jurídicas de direito internacional, segundo as regras gerais do direito internacional.

Segundo Mario Bettati, nada impede que a iniciativa de criação de uma organização internacional surja de um órgão interno de determinado Estado. O autor ilustra com o exemplo do Conselho Nórdico, cuja iniciativa de criação foi dos parlamentares nacionais, mas que se tornou uma efetiva organização internacional pela participação dos demais Estados. E aproveita para lembrar que as organizações internacionais se

\footnotetext{
${ }^{26}$ BETTATI, Mario. Création et personnalité juridique des organisations internationales. In: DUPUY, René Jean (Ed.). Manuel sur les organizations internationales. The Hague Academy of International Law Hage (Des Cours - Colloques, 87), p. 36. Tradução livre do seguinte original: "elles sont insuffisantes pour rendre compte du phénomène sous ses different aspects".

${ }^{27}$ WHITE, N. D. The law of international organizations, p. 27 e ss. faz uma análise interessante sobre a personalidade jurídica das OIs, lembrando-se de que o reconhecimento dessa personalidade não induz necessariamente todos os direitos e deveres próprios do regime internacional (p. 28). De fato, adiante serão analisadas as ideias decorrentes do princípio da especialidade.
} 
diferenciam das organizações não governamentais, geradas segundo o ordenamento jurídico interno de um Estado, ainda que tenham atuação internacional ${ }^{28}$.

Assim, se a organização internacional é criada em conformidade com as regras gerais de direito internacional, pela concorrência de Estados, por ato de celebração formal, então se aplicam a sua constituição as normas sobre direito dos tratados. E, de fato, é o que ocorre. A Convenção de Viena sobre Direito dos Tratados (CVDT), de 1969, recepcionada pelo Brasil, nos termos do Decreto $\mathrm{n}^{\mathrm{o}}$ 7.030, de 14 de dezembro de 2009, dispõe no artigo $5^{\text {o. }}$

A que presente Convenção aplica-se a todo tratado que seja o instrumento constitutivo de uma organização internacional e a todo tratado adotado no âmbito de uma organização internacional, sem prejuízo de quaisquer normas relevantes da organização.

A celebração de um tratado de criação de uma organização internacional está, portanto, sujeita às regras gerais do direito dos tratados, notadamente as consignadas na CVDT de 1969, por disposição expressa. Mario Bettati lembra que algumas particularidades devem ser respeitadas, ante a natureza peculiar e complexa das organizações internacionais:

La conclusion du traité constitutif se distingue donc de celle prévue pour le droit des traités par la nature particulière de la constitution de l'organisation internationale qui contient à la fois des dispositions normative (comme dans tous les traités) et des disposition institutionelles mettant en place des organes investis de fonctions internationales ellesmêmes génératrices de normes dérivées ${ }^{29}$.

Em outras palavras, o autor em comento e a doutrina ${ }^{30}$, de modo geral, lembram que a celebração de um tratado internacional de criação de uma organização

\footnotetext{
${ }^{28}$ BETTATI, Mario. Création et personnalité juridique des organisations internationales. In: DUPUY, René Jean (Ed.). Manuel sur les organizations internationales. The Hague Academy of International Law Hage (Des Cours - Colloques, 87), p. 36.

${ }^{29}$ Ibid., p. 36. Tradução livre: “A conclusão do tratado constitutivo se distingue, então, daquela previsão geral pelo direito dos tratados pela natureza particular da constituição da organização internacional, que contém as disposições normativas (como a de todos os tratados) e as disposições institucionais envolvendo os órgãos investidos de funções internacionais de geração de normas derivadas."

${ }^{30}$ No mesmo sentido, por exemplo, MARTINS, Margarida Salema D'Oliveira; MARTINS, Afonso D’Oliveira. Direito das organizações internacionais. 2. ed. Lisboa: Associação da Faculdade de Direito de Lisboa, 1996, v. I, p. 92. "O regime jurídico dos tratados instituidores das Organizações Internacionais apresenta, no entanto, especificidades em matérias tais como as da admissão de reservas e da sua entrada em vigor, interpretação e modificação."
} 
internacional vai além da imposição de respeito às normas daquele mesmo tratado. A participação em uma organização internacional induzirá ainda a observância de outras normas e comandos que venham a ser criados no seio da própria organização nascitura. É que o tratado, nesse caso em particular, poderá instituir órgãos dotados de competências normativas, executivas e judiciárias - para usar as expressões mais comuns na doutrina.

Ademais, ainda no que tange ao conteúdo do ato constitutivo, o tratado poderá prever a interação gradual dos Estados com as normas estatuídas ou até mesmo a derrogação de algumas normas em especial com relação a determinado membro. É o que ocorre, por exemplo, no tocante às Comunidades Europeias. Além disso, há especiais restrições à faculdade de reservas ao ato constitutivo, a bem da preservação da uniformidade de regime jurídico de que depende o bom funcionamento da organização. De fato, para além da doutrina crítica às reservas nesse tipo de tratado ${ }^{31}$, a CVDT, no artigo $20, \S 3$, estabelece que, "quando o tratado é um ato constitutivo de uma organização internacional, a reserva exige a aceitação do órgão competente da organização, a não ser que o tratado disponha diversamente".

A esse propósito, é pertinente mencionar a existência de Cartas que vedam a possibilidade de reservas, como, por exemplo, o Tratado de Montevidéu, de 18 de fevereiro de 1960. Esse documento, ao criar uma zona de livre comércio e instituir a Associação Latino-Americana de Livre Comércio, dispõe, no artigo 55, que o "Tratado não poderá ser assinado com reservas, nem estas poderão ser feitas por ocasião de sua ratificação ou adesão".

Superada essa etapa, cumpre avaliar o marco de sua entrada em vigor - com o nascimento efetivo da organização. A mais esse aspecto aplicam-se, igualmente, as regras gerais do direito dos tratados, que, a teor do artigo 24, estabelecem:

1. Um tratado entra em vigor na forma e na data previstas no tratado ou acordadas pelos Estados negociadores.

2. Na ausência de tal disposição ou acordo, um tratado entra em vigor tão logo o consentimento em obrigar-se pelo tratado seja manifestado por todos os Estados negociadores.

\footnotetext{
${ }^{31}$ MARTINS, Margarida Salema D'Oliveira; MARTINS, Afonso D’Oliveira. Direito das organizações internacionais, p. 94; BETTATI, Mario. Création et Personnalité Juridique des Organisations Internationales. In: DUPUY, René Jean (Ed.). Manuel sur les organizations internationales. The Hague Academy of International Law Hage (Des Cours - Colloques, 87), p. 35.
} 
Sabe-se, ademais, que, em face da disposição do $\S 1^{\underline{0}}$ do artigo 24 da CVDT, há possibilidade de cumulação de outras condições especiais, como a adesão de determinado Estado, particularmente relevante no que concerne ao objeto da Organização.

Outra questão bastante interessante e de especial relevância diz respeito à possibilidade de aplicação provisória de um tratado criador de organização internacional. Isso porque a Convenção que criou a Organização Europeia de Cooperação Econômica (OECE) - antecessora da OCDE - continha previsão nesse sentido (artigo 24, "b"). A esse propósito, Mario Bettati remete à disposição do artigo 25 da CVDT, que admite a hipótese de aplicação provisória, desde que o tratado disponha nesse sentido ou se os Estados interessados assim acordarem por outra forma ${ }^{32}$.

Ainda a respeito do tratado constitutivo, merece apreciação a questão das emendas. Na esteira dos demais aspectos, pode-se dizer, em princípio, que a regra geral aplicável ao direito dos tratados é igualmente aplicável ao regime das emendas às Cartas das organizações; entretanto, algumas especificidades devem ser acrescentadas.

A regra geral enuncia que os efeitos dos tratados só são aplicáveis em relação aos Estados que tenham aceitado a emenda, nos termos dos artigos 40.4 e 30.4.b da CVDT de 1969; contudo, no caso das organizações internacionais, a necessidade de efetiva convergência de interesses para a manutenção da unidade de regimes jurídicos e para o bom funcionamento da organização demanda que o ato constitutivo traga regras mais específicas acerca das emendas.

Daí abrirem-se três possibilidades, sendo a primeira da manutenção das regras gerais da CVDT de 1969; a segunda, do condicionamento à unanimidade; e a última, da vinculação de todos à vontade majoritária. Na síntese de Mario Bettati, "estas regras gerais devem ser completadas pelas disposições pertinentes aos atos constitutivos que preveem expressamente os processos de revisão ou emendas" ${ }^{\text {"33 }}$. Esse autor lembra, ainda, que essas disposições exprimem um equilíbrio entre a necessidade de perenizar o texto original e conferir flexibilidade ao texto segundo as circunstâncias e mudanças.

\footnotetext{
${ }^{32}$ BETTATI, Mario. Création et personnalité juridique des organisations internationales. In: DUPUY, René Jean (Ed.). Manuel sur les organizations internationales. The Hague Academy of International Law Hage (Des Cours - Colloques, 87), p. 41: 'L'application de l'acte constituif à titre provisoire est exceptionel. Il est assez rare que l'acte constituif s'applique à titre provisoire bien qu'une telle possibilité soit licite (Convention de Vienne, art. 25), et qu'elle ait fait l'objet de dispositions particulières pour l'OECE: 'en attendant l'entrée en vigueur de la Convention, [...] les signataires conviennent, afin d'éviter tout délai dans son exécution, de La mettre en application dès sa signature, à titre provisoire.' (art. 24 b))."

${ }^{33}$ Ibid., p. 42. Tradução livre do seguinte original: "ces règles générales doivent être complétées par les dispositions pertinentes des actes constitutifs qui prévoient expressément leurs procédures de révision ou d'amendment."
} 


\subsubsection{A Sucessão}

A Organização para Cooperação e Desenvolvimento Econômicos (OCDE) surgiu a partir da Organização Europeia de Cooperação Econômica (OECE). Mas seria esse um caso de sucessão?

A esse propósito, importa lembrar, com a doutrina, algumas formas pelas quais é possível considerar haver uma sucessão entre organizações internacionais. Essa sucessão será reconhecida pela identidade de funções, de nome, de agentes ou de patrimônio, e poderá ocorrer com o aparecimento da sucessora e o simultâneo desaparecimento da sucedida, ou com o aparecimento de uma dissociada da dissolução da outra.

Além disso, uma sucessão pode ocorrer por meio de acordos de sucessão entre os próprios Estados envolvidos; ou pode ser por atos de transferência emanados do seio das próprias organizações interessadas ${ }^{34}$.

Nesse último caso, reconhece-se a necessidade de concordância dos Estados que sejam parte da organização sucedida. Mario Bettati lembra, por exemplo, da sucessão da Sociedade das Nações pela Organização das Nações Unidas (ONU) ${ }^{35}$.

Naquele caso em particular, o tratamento do assunto se deu segundo os acordos formalmente estabelecidos pelos Estados envolvidos - embora nem sempre seja assim. Na ausência de regras estipuladas em cada caso específico, problemas de interpretação podem surgir, uma vez que não há regras gerais de direito internacional a respeito desse tema diferente do que se tem para o caso da sucessão entre Estados ${ }^{36}$.

\footnotetext{
${ }^{34}$ BETTATI, Mario. Création et personnalité juridique des organisations internationales. In: DUPUY, René Jean (Ed.). Manuel sur les organizations internationales. The Hague Academy of International Law Hage (Des Cours - Colloques, 87), p. 45.

${ }^{35}$ Ibid., p. 46: 'Deux ensemble peuvent être distingués: i) D'abord une combinaison d'actes uni- et bilateraux de transfert comprenant des résolution associées à des accords interorganisation. Ainsi, pour le transfert SDN/ONU on trouve successivement: à l'ONU la résolution A 24 [1] du 12 février 1946; à la SDN la résolution parallèle du 18 avril 1946: puis l'accord SDN/ONU du 19 juillet 1946, l'arrangement du 31 juillet 1946 et le Protocole du 1er août 1946, concernentles biens mobiliers et immobiliers, les dettes et les créances, enfin les résolutions d'approbation de ces accords par l'Assemblée générale des Nations Unies; résolution 79 [1] du 7 décembre 1946; ii) Ensuite une combination d'actes uni- et multilatéraux de transfert comme pour la substituition de l'UAMCE à l'UAM, issue de la résolution adoptée par les chefs d'Etat et de gouvernement de l'UAM à Dakar le 10 mars 1964, suivie du paraphe de la Charte de l'UAMCE à Nouakchott le 30 avril 1964, puis la creation de l'OCAM, décidée par un comunique final de la conferénce de Nouakchott, en février 1965, OCAM dont le traité constituif n'a été signé que le 26 juin 1966".
}

${ }^{36}$ CAMPOS, João Mota et al. Teoria geral das organizações internacionais. Lisboa: Fundação Calouste Gulbenkian, 1999. p. 72. 
Salienta-se, assim, nas palavras de Campos, que "cada caso terá de ser considerado de 'per se' com base em acordos formais dos Estados-membros ou dos órgãos competentes das OI em causa".

No caso da Organização para Cooperação e Desenvolvimento Econômicos, os Estados da Organização Europeia de Cooperação Econômica celebraram uma Convenção, cujo texto fala em reconstituição - a teor do artigo 15 da Convenção assinada em Paris, em 14 de dezembro de 1960, transcrita no subitem 1.3, e conforme menção preambular.

Poder-se-ia indagar, então: essa reconstituição é uma mera mutação ou uma efetiva sucessão? Mario Bettati trata o caso como uma verdadeira sucessão; já o autor português João Mota Campos refere-se a ele, inicialmente, sob o título de mutação. Do ponto de vista prático, as aproximações se equivalem, especialmente a considerar que a Convenção de 1960 regulou de maneira cuidadosa o processo. Tanto é assim que, mais adiante, João Mota Campos inclui o exemplo da OECE-OCDE dentre as hipóteses de sucessão ${ }^{37}$.

A doutrina trata, portanto, a relação da OECE-OCDE como se fosse tanto uma sucessão como uma transformação - inclusive no contexto de que a transformada é, na verdade, sucessora da que se transformou. Do ponto de vista prático, não há o que justifique alongar-se no debate, pois as relações estão detalhadamente definidas na Convenção de 1960.

\subsection{A Sistemática de Atuação da OCDE}

O método de trabalho da OCDE é, certamente, um dos principais legados da OECE, já que dela decorreu inegável eficácia na implantação das políticas e dos princípios propostos pela Organização, na década seguinte à da Segunda Guerra, na Europa.

\footnotetext{
${ }^{37}$ CAMPOS, João Mota et al. Teoria geral das organizações internacionais, p. 65. No entanto, o mesmo autor, pouco adiante, refere-se ao caso como sucessão: p. 69: "Foi o que sucedeu, por exemplo, no caso da substituição da OECE pela OCDE. Os Estados-membros da primeira previram a sucessão e regularam as questões daí resultantes: a novel OCDE foi instalada na sede da extinta OECE, no Palácio de La Muete, no Bosque de Bolonha, em Paris; e ficou a dispor de uma estrutura orgânica idêntica à da sua antecessora, para a qual transitaram os bens e serviços da organização extinta. A nova engrenagem institucional passou por isso a funcionar sem solução de continuidade e sem sobressaltos, no serviço de objetivos predefinidos. E sem sequer a participação de novos Estados-membros, extraeuropeus, representou um fator de perturbação no funcionamento da OI, até porque alguns deles lhe estavam já ligados na qualidade de associado (caso dos Estados Unidos e do Canadá).”.
} 
Nas palavras do diplomata brasileiro Denis Fonte de Souza Pinto, a capacidade da OCDE de transformar a teoria, resultado de séria reflexão, em prática com resultados é um ponto a merecer destaque: "a OCDE tem a capacidade de temperar a teoria acadêmica com a análise factual e gerar recomendações de políticas que correspondam às necessidades dos países-membros" ${ }^{\text {"38. }}$.

A sistemática da OCDE caracteriza-se, nesse sentido, pela associação do think tank (produção de conhecimentos), rule maker (elaboração de normas) e do peer pressure (pressão dos pares). Esses três aspectos, como bem identificados por Denis Fonte de Souza Pinto, envolvem a atividade de pesquisa e formulação de estratégias, aliados à coordenação de posições e ao acompanhamento constante - como era necessário nos primeiros anos da OECE.

Além disso, OCDE atua, de certo modo, como uma espécie de tribunal das políticas dos países. Importa mencionar, a esse respeito, que a OCDE evita envolver, em suas matérias, cortes internacionais, preferindo a resolução negociada internamente. Essa é mais uma aplicação do princípio de se buscar sempre decisões consensuais e à base da persuasão.

Ressalte-se, contudo, que toda a atividade e eficácia das ações da OCDE não têm como fundamento o poder financeiro, já que, embora reúna economias centrais, não possui poder financeiro comparado ao Banco Mundial ou mesmo ao Fundo Monetário Internacional (FMI); no mesmo sentido, como lembra Denis Fonte de Souza Pinto ${ }^{39}$, também não tem competência supranacional, tal qual a União Europeia, e, muito menos, poder vinculatório, como o órgão de solução de controvérsias da Organização Mundial do Comércio (OMC).

Mas a OCDE tem, a seu favor, esse sistema fundado na persuasão. É nele que são construídos o consenso e a observância de normas eleitas e desejadas por seus membros, individualmente. Além disso, não é só a forte legitimidade da norma que convida a sua observância; a herança da função fiscalizadora, fundada no acompanhamento e cobrança do cumprimento de compromissos, é uma nota distintiva do sistema da OCDE.

A função fiscalizadora, como se sabe, foi um mecanismo pensado na OECE para dar conta dos resultados esperados pela aplicação dos recursos, segundo arbitrado

\footnotetext{
${ }^{38}$ Think tank, peer pressure e rule maker são três das características destacadas por Denis Fontes de Souza Pinto (OCDE: uma visão brasileira. Brasília: IRBR, 2000. p. 19).

${ }^{39}$ Ibid., p. 18.
} 
pelos Comitês Técnicos, envolvendo a função regulatória; portanto, de modo geral, podese dizer que o processo de atuação da OCDE envolve a fiscalização sobre atos emanados do consenso, sob ampla discussão desenvolvida com base em conhecimentos técnicos produzidos internamente.

Como será possível verificar adiante, há diferentes atos emanados pela Organização, com suas características de vinculação ou não. Num primeiro caso, por exemplo, tem-se um processo que se desenvolve com base em estudos técnicos e circulação desses conhecimentos, inclusive em instâncias confidenciais. Esse processo culmina com a emissão de relatórios expressando consenso, aprovado pelos membros de determinado Comitê, que podem ser complementados com recomendações. O documento final, por sua vez, pode não ser de cumprimento obrigatório, mas tem elevado grau de cobrança dos outros países. Nisso consiste o peer pressure, que conta com mecanismos de acompanhamento e fiscalização mesmo para o caso de relatórios.

Ressalte-se que a maioria dos atos emanados da OCDE tem a natureza de recomendações ${ }^{40}$, não sendo, por isso, de caráter obrigatório - muito embora sujeitos ao acompanhamento e à pressão própria do sistema. As recomendações apresentam muitas vantagens, já que permitem certa margem de manobra na sua negociação, privilegiando a adaptabilidade. Essas características são de central relevância no contexto da construção de consenso e, ainda, no incentivo às posturas corretivas dos Estados, com vistas a atingir um patamar ideal ou sedimentado.

As recomendações apontadas, por essa última característica enunciada, são úteis especialmente em setores pouco regulados. É que a construção de normas e padrões depende, quase sempre, da iniciativa incipiente e gradual.

Outro aspecto a ser mencionado diz respeito à possibilidade de haver reservas/condicionantes ${ }^{41}$ nos atos da OCDE, embora não desejadas:

[...] Essa flexibilidade, entretanto, não deixa de ser paulatinamente restringida pelos mecanismos de acompanhamento e de exame característicos da Organização e que têm no peer pressure seu instrumento por excelência ${ }^{42}$.

\footnotetext{
${ }^{40}$ Cf. item 2.3, adiante.

41 Os Estados podem "qualificar sua aceitação" quanto a determinado ato, durante a apreciação pelo Conselho. Nesse sentido: PINTO, Denis Fontes de Souza. OCDE: uma visão brasileira, p. 24.

${ }^{42}$ Ibid., loc. cit.
} 
A OCDE procura construir sua legitimidade sobre o consenso fundado em pesquisa e sobre valores sempre compartilhados, acompanhando as providências dos membros e contando com a pressão dos pares - mesma sistemática com a qual sua antecessora, a OECE, obteve efetivos resultados.

\subsection{Estrutura da OCDE: Resolução Revisada do Conselho sobre uma Nova Estrutura de Governança para a Organização}

A OCDE tem como estrutura básica um Conselho, um Secretariado e vários Comitês Temáticos. Como se disse, a Organização funciona pautada na interação dessas três categorias, cabendo aos Comitês o desenvolvimento temático, com base nas pesquisas, ao Secretariado a análise e proposição dos assuntos e ao Conselho a supervisão e a direção estratégica. Essa montagem é também uma herança da OECE.

O Conselho é o órgão de direção e supervisão da OCDE, composto por representantes dos Estados-membros e da Comissão Europeia ${ }^{43}$, e suas decisões são tomadas por consenso. O órgão se reúne com regularidade, pela composição dos representantes permanentes, mas uma vez ao ano há uma reunião ministerial, na qual são discutidos os principais problemas e as prioridades de trabalho ${ }^{44}$.

Dos Comitês participam não apenas os representantes dos Estados-membros, mas também de outros participantes não membros ${ }^{45}$. Os Comitês são os responsáveis pela discussão e pela implementação das políticas adotadas pela OCDE, notadamente pelas decisões do Conselho. Além dos Comitês, podem ser criados Grupos de Trabalho e Grupos

\footnotetext{
${ }^{43}$ O artigo 231 do Tratado de Roma (1957) estabelece uma relação de proximidade entre as organizações: "ARTICLE 231 - The Community shall establish close co-operation with the Organisation for European Economic Co-operation, the details to be determined by common accord." Nesse sentido, o documento denominado Supplementary Protocol No. 1 to the Convention on the OECD assim dispõe:

"1. Representation in the Organisation for Economic Co-operation and Development of the European Communities established by the Treaties of Paris and Rome of 18th April, 1951, and 25th March, 1957, shall be determined in accordance with the institutional provisions of those Treaties.

2 The Commissions of the European Economic Community and of the European Atomic Energy Community as well as the High Authority of the European Coal and Steel Community shall take part in the work of that Organisation." Esse tratado foi alterado pelos Tratados de Maastricht (1992) e Nice (2003) resultando na União Europeia, que, nesses termos, sucedeu a posição da Comunidade Econômica Europeia. A Comissão Europeia, por sua vez, é o órgão executivo da União Europeia e representa os interesses da Europa.

44 Disponível em: <http://www.oecd.org/pages/0,3417,fr_36734052_36761791_1_1_1_1_1,00.html>. Acesso em: 14 jun. 2011.

${ }^{45}$ Cf. item 3.1, no Capítulo 3 deste estudo.
} 
de Especialistas, para tratar de assuntos específicos, desenvolvendo ideias e "revendo o progresso em áreas de políticas específicas" "46 . São mais de 250 Comitês e Grupos.

O Secretariado mantém estrita relação de trabalho com os Comitês, cabendo a ele levar a cabo as tarefas designadas pelo Conselho com colaboração deles. O Secretariado é composto por um Secretário Geral e outros denominados Secretários Gerais adjuntos, além de Diretores, organizados por área, e uma equipe de apoio de cerca de 2,5 mil profissionais das mais variadas áreas de formação ${ }^{47}$.

A lista dos Comitês e Grupos da OCDE pode ser consultada diretamente no sítio eletrônico da instituição. Vale anotar que o Comitê de Investimentos é um desses, sendo composto por representantes dos 34 Estados-membros da OCDE, e ainda por Brasil e Argentina como observadores. Integram também o Comitê de Investimentos antigamente referido como Comitê de Investimentos e Empresas Multinacionais (Cime) o Fundo Monetário Internacional (FMI), a Conferência das Nações Unidas para Comércio e Desenvolvimento (Unctad), o Banco Mundial (BM) e a Organização Mundial do Comércio (OMC).

Em dezembro de 2010, o Conselho da OCDE aprovou as mais recentes alterações à Resolução C(2006)78/VER/FINAL, denominada Revised Resolution of the Council on a New Governance Structure for the Organization. Esse documento, por sua vez, adota um anexo contendo quatro capítulos. O primeiro deles trata da orientação política, com ênfase para as diretivas relacionadas à ampliação das ações da organização com vistas ao futuro. O capítulo seguinte trata da estrutura de governança da OCDE, abordando os temas relacionados à Convenção da OCDE, ao Conselho, às reuniões dos chefes de delegação, ao Secretário Geral, aos comitês temáticos, às relações entre o Conselho e os comitês temáticos, aos procedimentos escritos e relatórios orais e às gerências do tempo e das reuniões. O capítulo 3 trata da estrutura e dos mecanismos de processos decisórios. Por fim, como é costume na OCDE, há um capítulo dispondo sobre as revisões e a implementação dos compromissos.

\footnotetext{
${ }^{46}$ PINTO, Denis Fontes de Souza. OCDE: uma visão brasileira, p. 24.

${ }^{47}$ Ibid., loc. cit.
} 


\section{CAPÍTULO 2}

\section{OS ATOS DA OCDE E O DIREITO BRASILEIRO}

\subsection{Atos das Organizações Internacionais no Contexto Cooperativo}

$\mathrm{O}$ artigo $1^{\underline{0}}$, item 3, da Carta das Nações Unidas ${ }^{48}$ afirma o princípio da cooperação internacional como meio para resolver os problemas internacionais e, centralmente, para promover e estimular o respeito aos direitos humanos e às liberdades fundamentais. De fato, o pós-Guerra é marcado por uma evidente mudança de paradigma: se por um lado a Sociedade das Nações tinha como meta fundamental a garantia da paz e da segurança entre as nações, por outro, a Carta da ONU é mais profunda e se pauta pela promoção dos direitos fundamentais como objetivo central ${ }^{49}$.

Nesse contexto, Peter Häberle defende que a realização internacional conjunta de valores tidos como fundamentais e universais é um imperativo jurídico ${ }^{50}$; ademais, na lição de Dan Sarooshi, na mesma linha, no pós-Guerra as fronteiras soberanas não podem constituir um obstáculo para a resolução de questões que não podem ser tratadas isoladamente pelos Estados, individualmente ${ }^{51}$.

\footnotetext{
${ }^{48}$ A cooperação internacional é decorrência de uma opção política, historicamente justificada, dos Estados signatários da Carta de São Francisco, em 26 de junho de 1945. O documento que criou a Organização das Nações Unidas (ONU) e recebeu inúmeras adesões nos anos seguintes menciona, expressamente, entre seus propósitos e princípios, o de "Conseguir uma cooperação internacional para resolver os problemas internacionais de caráter econômico, social, cultural ou humanitário, e para promover e estimular o respeito aos direitos humanos e às liberdades fundamentais para todos, sem distinção de raça, sexo, língua ou religião".
}

${ }^{49}$ A esse respeito: DALLARI, P. B. de Abreu. Atualidade da Declaração Universal dos Direitos Humanos. Política Externa, USP, v. 17, p. 55-65, 2008.

${ }^{50}$ HÄBERLE, Peter. Estado constitucional cooperativo. São Paulo: Renovar, 2007.

${ }^{51}$ SAROOSHI, Dan. International organizations and their exercise of sovereign powers. New York: Oxford University Press, 2005. p. 119: "The contestations between States over rival conceptions of sovereignty within international organizations are often the very same contestations of sovereignty that have been, and are still, occurring within nation-State. They are about the central problem of sovereignty: what powers are reserved to government; who exercises which of them, and how should they be exercised? In this respect, international organizations play an important role as a forum, transcendental to the State, where sovereign values that constrain the exercise of sovereign powers can be contested and developed. The challenge for international organizations exercising broad powers of government is to develop these values in conjunction with, rather than instead of, States and their organs of government." Tradução livre: “A contestação entre os Estados sobre as concepções rivais de soberania no âmbito das organizações internacionais são muitas vezes a mesma contestação de soberania que têm ocorrido no âmbito do Estado-nação. Elas versam sobre o problema central da soberania: que poderes são reservados para o governo, quem exerce qual deles, e como devem ser exercidos? A esse respeito, as organizações internacionais desempenham um papel importante como um fórum, transcendental para o Estado, onde os valores soberanos que restringem o exercício de poderes soberanos podem ser contestados e desenvolvidos. O desafio para as organizações internacionais que 
De fato, o zelo pela efetividade de sistemas jurídicos construídos sobre bases de respeito aos direitos fundamentais e à dignidade humana é um objetivo que guarda identidade com os princípios da Carta da ONU. Guarda, igualmente e no mesmo sentido, relação com os tratados internacionais sobre direitos humanos. E, nesses termos, os limites territoriais, como barreiras intransponíveis para a realização desses valores, tornam a soberania e a jurisdição um obstáculo, em vez de um meio.

Nesse contexto, a ideia de cooperação internacional demanda uma visão do conceito de soberania conformado mais pelo poder-dever do que pelo poder-afirmação. Assim é que a visão proposta por Häberle nega a ideia de soberania como conceito estático - prestigiando um conceito útil ao contexto da cooperação, que exige interação das questões internas e externas. Em outras palavras: não se trata mais de entender o dever de um Estado por cooperar como enfraquecimento de sua soberania, por limitação de suas possibilidades de se negar a tanto; ao contrário, a cooperação significa uma reafirmação estatal de suas finalidades de promoção dos valores essenciais, de forma coletiva. Implica, dessa maneira, compreender a importância das interações estatais na afirmação da soberania estatal, enquanto instrumento para a realização de valores universais ${ }^{52}$.

Para alinhar as relações entre os Estados, no anseio de realizar objetivos comuns, a criação de uma organização internacional é uma ferramenta muito eficiente. $\mathrm{E}$, de fato, a história mostra que a atuação da OECE foi decisiva para a reconstrução econômica, com reflexos importantes na promoção dos direitos fundamentais. Nesse aspecto, a atuação da OECE foi sucedida pela atuação da OCDE, cujos atos, em muitos casos, vinculam os Estados-membros. Isso significa que há interação dos atos da organização internacional com o direito interno, e que essa relação é ainda mais marcante quando envolve - como no caso em estudo - um Estado não membro da organização.

É inegável, nesse sentido, que as relações de cooperação - especialmente sob determinadas formas - acabam atingindo um ponto em que as condições do sistema jurídico interno são intensamente confrontadas com os compromissos cooperativos assumidos pelo Estado. Haverá, nisso, um problema de soberania?

exercem amplos poderes de governo é desenvolver esses valores em conjunto com, ao invés de, os Estados e seus órgãos de governo."

${ }^{52}$ A esse propósito: ARAÚJO, N. A importância da cooperação jurídica internacional para a atuação do Estado brasileiro no plano interno e internacional. In: DEPARTAMENTO DE RECUPERAÇÃO DE ATIVOS E COOPERAÇÃO JURÍDICA INTERNACIONAL - DRCI. Manual de cooperação jurídica internacional e recuperação de ativos- matéria civil. Brasília: Secretaria Nacional de Justiça, Ministério da Justiça, 2008. 
A cooperação internacional pode levar - mais cedo ou mais tarde - ao problema de oposição entre os elementos de soberania e a interferência externa em questões domésticas. Se, por um lado, Häberle propõe uma nova aproximação da ideia de soberania, por outro, Anne-Marie Slaughter ${ }^{53}$ desenvolve ainda mais o assunto. Segundo o ponto de vista deste último, os Estados só podem ter um "governo" efetivo se cooperarem ativamente com outros Estados e se reservarem coletivamente o poder de intervir em assuntos de outros estados.

Pode-se dizer que esse pensamento é absolutamente compatível com a concepção de uma organização internacional - como instância coletiva. Nesse contexto, Slaughter ${ }^{54}$ defende que a soberania deve ser tida como a capacidade de participar nos regimes internacional e transnacional - agora necessária para permitir ao governo conseguir, por meio da cooperação mútua, o que eles apenas esperariam conseguir agindo isoladamente em um território definido.

Mas a relação cooperativa envolve múltiplas partes e, portanto, múltiplos Estados com seus ordenamentos jurídicos e, ainda, em rigor, uma norma internacional que pode ser, inclusive, a carta de criação de determinada organização internacional.

Pois bem, há algumas vias para a cooperação internacional, mas a relação primordial de direito internacional é a que decorre dos tratados; tanto é assim, que o Estatuto da Corte Internacional de Justiça, no artigo 38, indica, em primeiro lugar, "as convenções internacionais, quer gerais, quer especiais, que estabeleçam regras expressamente reconhecidas pelos Estados".

Importa observar que essa é, certamente, uma herança da concepção voluntarista do direito internacional. Seja como for, e a despeito da extrema importância do costume e dos princípios gerais de direito, a celebração de um tratado internacional é uma fonte nuclear do direito e, do mesmo modo, instrumento para a cooperação jurídica internacional. No sistema jurídico brasileiro, por exemplo, a relação entre o direito interno e o direito internacional é quase sempre problematizada em decorrência dos tratados.

A esse propósito, note-se que o sistema constitucional brasileiro lida com a relação entre direito interno e direito internacional de maneira bastante sucinta, para um texto constitucional de caráter predominantemente analítico. As disposições que tratam da sistemática de incorporação de normas internacionais são apenas o artigo 84, inciso VIII,

${ }^{53}$ SLAUGHTER, Anne-Marie, Sovereignty and power in a networked world order. Stanford Journal of International Law, n. 40, p. 283-327, 2004.

54 Ibid. 
que determina sobre a competência do Presidente da República para celebrar tratados, e o artigo 49, inciso I, além do artigo $5^{\circ}$, $\S 3^{\circ}$, todos da Constituição Federal hodierna.

Nesse campo, da recepção e internalização de atos internacionais, a jurisprudência exerce um papel importante, exatamente por conta da exiguidade com que o tema é tratado no texto constitucional. Isso lhe confere, sob certa medida, uma mutabilidade mais intensa, já que não está cercada pelos muros da regra.

Em síntese, verifica-se a existência de um sistema constitucional com tratamento analítico bastante limitado, no tocante às relações entre direito interno e direito internacional. Destaque-se, a esse respeito, que a OCDE é uma organização de cooperação, da qual o Brasil não é membro, mas com a qual mantém relações importantes - como no caso objeto do presente trabalho. No entanto, a sua compreensão perante as regras constitucionais não se mostram óbvias. Pode-se dizer até mesmo que essa situação revela um contexto de limitações e dificuldades decorrentes da crescente intensificação das relações internacionais do Brasil, diante dessa cultura constitucional analítica, mas com insuficientes disposições sobre o assunto. Daí, duas soluções serão possíveis: a revisão do texto, ou a aplicação mais ativista do disposto no artigo $4^{\circ}$ da Constituição Federal.

$\mathrm{O}$ artigo $4^{\mathrm{o}}$ da Constituição Federal $^{55}$, por sua vez, é o dispositivo que evidencia os princípios da República nas relações internacionais. Destaque-se, a propósito do tema ora tratado, o princípio da “cooperação entre os povos para o progresso da humanidade",56.

\footnotetext{
55 “Art. 4․ A República Federativa do Brasil rege-se nas suas relações internacionais pelos seguintes princípios:

I - independência nacional;

II - prevalência dos direitos humanos;

III - autodeterminação dos povos;

IV - não-intervenção;

$\mathrm{V}$ - igualdade entre os Estados;

VI - defesa da paz;

VII - solução pacífica dos conflitos;

VIII - repúdio ao terrorismo e ao racismo;

IX - cooperação entre os povos para o progresso da humanidade;

$\mathrm{X}$ - concessão de asilo político.

Parágrafo único. A República Federativa do Brasil buscará a integração econômica, política, social e cultural dos povos da América Latina, visando à formação de uma comunidade latino-americana de nações."

${ }^{56}$ A esse respeito: DALLARI, P. B. de Abreu. Constituição e relações exteriores. São Paulo: Saraiva, 1994, p. 179: "A abordagem constitucional do princípio da cooperação entre os povos salienta a contradição
} 
O Ministro Gilmar Mendes, ao apontar essa questão, mas sem inovar, assim escreve em decisão monocrática, liminar em Ação Cautelar:

O texto constitucional admite a preponderância das normas internacionais sobre normas infraconstitucionais e claramente remete o intérprete para realidades normativas diferenciadas em face da concepção tradicional do direito internacional público.

Refiro-me aos arts. $4^{\underline{0}}$, parágrafo único, e $5^{\circ}$, parágrafos $2^{\circ}, 3^{\circ}$ e $4^{\circ}$, da Constituição Federal, que sinalizam para uma maior abertura constitucional ao direito internacional e, na visão de alguns, ao direito supranacional $^{57}$.

Verifica-se, dessa maneira, que o desenvolvimento do direito interno, no tocante às demandas de sua relação com o direito internacional, requer um exercício hermenêutico intenso, tanto mais hoje perante a ausência de normas mais variadas e

presente na ausência de referência às organizações internacionais. Isto porque tem-se dado fundamentalmente por meio delas a materialização de sistemas de ajuda mútua no plano internacional."

${ }^{57}$ BRASIL. Supremo Tribunal Federal. AC 2.436, Rel. Min. Gilmar Mendes, julgamento em 3 set. 2009. Há, ainda, de interesse, o seguinte trecho complementar, da lavra do referido Ministro: "Não se pode ignorar que os acordos internacionais demandam um extenso e cuidadoso processo de negociação, de modo a conciliar interesses e concluir instrumento que atinja os objetivos de cada Estado, com o menor custo possível.

Essa complexa cooperação internacional é garantida essencialmente pelo pacta sunt servanda. No atual contexto da globalização, o professor Mosche Hirsch, empregando a célebre Teoria dos Jogos (Game Theory) e o modelo da Decisão Racional (Rational Choice), destaca que a crescente intensificação (i) das relações internacionais; (ii) da interdependência entre as nações, (iii) das alternativas de retaliação; (iv) da celeridade e acesso a informações confiáveis, inclusive sobre o cumprimento por cada Estado dos termos dos tratados; e (v) do retorno dos efeitos negativos (rebounded externalities) aumentam o impacto do desrespeito aos tratados e privilegiam o devido cumprimento de suas disposições (HIRSCH, Mosche. 'Compliance with International Norms' in The Impact of International Law on International Cooperation. Cambridge: Cambridge University Press, 2004. p. 184-188). Tanto quanto possível, o Estado Constitucional Cooperativo demanda a manutenção da boa-fé e da segurança dos compromissos internacionais, ainda que em face da legislação infraconstitucional, pois seu descumprimento coloca em risco os benefícios de cooperação cuidadosamente articulada no cenário internacional. Importante deixar claro, também, que a tese da legalidade ordinária, na medida em que permite às entidades federativas internas do Estado brasileiro o descumprimento unilateral de acordo internacional, vai de encontro aos princípios internacionais fixados pela Convenção de Viena sobre o Direito dos Tratados, de 1969, a qual, em seu art. 27, determina que nenhum Estado pactuante 'pode invocar as disposições de seu direito interno para justificar o inadimplemento de um tratado'. Ainda que a mencionada convenção ainda não tenha sido ratificada pelo Brasil, é inegável que ela codificou princípios exigidos como costume internacional, como decidiu a Corte Internacional de Justiça no caso Namíbia [Legal Consequences for States of the Continued Presence of South África in Namíbia (South West África) notwithstanding Security Council Resolution 276 (1970), First Advisory Opinion, ICJ Reports 1971, p. 16, §§ 94-95]. A propósito, defendendo a interpretação da constituição alemã pela prevalência do direito internacional sobre as normas infraconstitucionais, acentua o professor Klaus Vogel que 'de forma crescente, prevalece internacionalmente a noção de que as leis que contrariam tratados internacionais devem ser inconstitucionais e, consequentemente, nulas' (Zunehmendsetztsichinternational die Auffassungdurch, dassGesetze, die gegenvölkerrechtliche Verträgeverstoßen, verfassungswidrigunddahernichtigseinsollte) (VOGEL, Klaus. 'Einleitung' Rz. 204-205 in VOGEL, Klaus \& LEHNER, Moris. Doppelbesteuerungsabkommen. 4. ed. München: Beck, 2003. p. 137-138). Portanto, parece evidente que a possibilidade de afastar a aplicação de normas internacionais por meio de legislação ordinária (treaty over ride), inclusive no âmbito estadual e municipal, está defasada com relação às exigências de cooperação, boafé e estabilidade do atual cenário internacional e, sem sombra de dúvidas, precisa ser revista por essa Corte." 
específicas. Esse movimento deve fundar-se na preocupação por dar efetividade ao princípio da cooperação internacional - previsto na Carta da ONU e na Constituição Federal brasileira - e em uma nova concepção de soberania, mas sem preterir a segurança jurídica. De fato, por não se tratar de algo óbvio, sua construção demanda muita ponderação.

\subsection{Poderes das Organizações Internacionais}

Discutir o tema dos poderes de uma organização internacional permite fazer aproximações distintas - embora relacionadas. Do ponto de vista da teoria das relações internacionais, por exemplo, as várias escolas se ocupam das relações de poder em si, enquanto, do ponto de vista jurídico, sob forte influência positivista, a maioria dos autores se preocupa em sistematizar as expressões do poder das organizações internacionais, mas sem se esquecer do estudo de sua efetividade - estritamente relacionada com as teorias das relações internacionais.

A esse propósito, é valioso considerar que, a tomar o ponto de vista de escolas realista e marxista, a organização internacional não passará, essencialmente, de uma arena de discussões; um foro de encontro e balanço de poder ${ }^{58}$. De fato, essa visão determinará, por consequência, certa aproximação no que toca aos poderes de uma organização internacional, em que o ente não é dotado de qualquer autonomia e, ao que se pode entender, não deteria efetivo poder normativo. A noção de poderes da organização, nesse caso, é relativizada e restrita.

De modo não muito diferente, a visão funcionalista entende que as organizações internacionais são instrumentos de utilidade dos Estados, por eles dirigidas ${ }^{59}$. Mesmo os mandatos conferidos pelos Estados às organizações internacionais, incluindo aqueles que limitam a atuação estatal, não se afiguram como efetiva renúncia ou forma de cessão de soberania estatal, mas verdadeira afirmação de soberania estatal. São os interesses do Estado que o levam a aceitar determinado mandato ou poder da organização internacional, que poderia ser simplesmente recusado. Sob esse enfoque, a noção de poder da organização internacional é também restritiva.

\footnotetext{
${ }^{58}$ WHITE, N. D. The law of international organizations, p. 37.

${ }^{59}$ ALVAREZ, José E. International organizations as law-makers, p. 24.
} 
De fato, as nuances de cada escola podem ser bastante sutis, e as percepções podem ser úteis para as análises práticas. Ainda que se pretenda que o comando do artigo 2(4) da Carta da ONU seja um direito cogente, vinculante, a experiência sinaliza que essa cogência pode ser relativizada segundo o poder de determinado Estado. O passado recente mostra que a invasão americana ao Iraque prescindiu de aprovação do Conselho de Segurança da ONU, de modo a comprovar certa razão à teoria realista, por exemplo.

No que tange à Organização para Cooperação e Desenvolvimento Econômicos (OCDE), sabe-se, conforme reiterado ao longo deste trabalho, que é sucessora da OECE (Organização Europeia de Cooperação Econômica). A OECE surgiu de uma necessidade específica: organizar e coordenar os esforços e a aplicação dos investimentos para a recuperação do continente, no pós-Guerra ${ }^{60}$. Àquela altura, concluiu-se que o déficit de efetividade dos valores liberais era um problema - que inclusive teria contribuído para as crises que concorreram para a eclosão da guerra. Nesse contexto, a OECE foi dotada de poderes de decisões vinculantes, segundo ato de seus próprios membros; e a sua sucessora - a OCDE - carregou consigo essa característica, considerada eficaz e valiosa exatamente porque fundada no consenso. Assim, a gênese do poder da OCDE está relacionada com a consensualidade; trata-se de uma organização fundada no consenso, contando, com isso, com grande legitimidade e eficiência - elementos que podem ser associados a um grau de poder elevado.

No entanto, o que se percebe com mais facilidade, ao se avaliar a atuação da OCDE, é o seguinte: embora a organização busque promover os valores liberais, e apesar de sua antecessora ter obtido inegável sucesso em seus objetivos, denotando grande poder de influência sobre os membros, é certo que esse poder - no sentido aqui aplicado - não foi e nem é absoluto. Um fato que exemplifica bem o limite de poder (capacidade de interferir na realidade dos membros promovendo seus valores) da OECE/OCDE é a permanência de políticas de subsídios agrícolas (elevados, aliás), aparentemente conflitantes com os propósitos da Organização e dos compromissos que os Estados assumem perante a Organização.

Isso pode levar a uma conclusão bem traduzida por um dito popular: não se pode ser mais realista do que o rei. O direito, no âmbito interno ou externo, é uma ciência social, e dialoga constantemente com a sociedade; não é um trilho rigoroso e perfeito, e sua realização não pode ser confiada apenas ao poder de coação. Ao contrário, percebe-se,

\footnotetext{
${ }^{60}$ Sem esquecer, conforme comentário anteriormente lançado em nota de rodapé, a existência de posição tradicionalista que destaca os interesses políticos de combate ao comunismo como razão de ser da OCDE.
} 
modernamente, que o poder pode ser mensurado pela legitimidade e pela efetividade e que, nesse contexto, a força da adesão voluntária e a construção consensual de normas são um elemento que confere especial eficácia ao direito (e poder a uma organização) - o que é salutar. O direito deve, nessa realidade, ser relacionado não simplesmente ao poder de coação, mas também ao poder de influência e de alteração da realidade ${ }^{61}$.

Daí evidenciar-se uma importante questão: as organizações internacionais detêm poder de fonte do direito? Para um positivismo clássico, como lembra José E. Alvarez $^{62}$, o direito internacional emana da vontade dos Estados, e não da organização internacional. Aliás, é esse o mandado do artigo 38 do Estatuto da Corte Internacional de Justiça (CIJ), aceito classicamente como o rol oficial de fontes do direito internacional.

Isso, no entanto, não encerra a questão. O Estatuto da CIJ decorre de um documento produzido antes mesmo da Segunda Guerra Mundial - pautado no Estatuto da Corte Permanente de Justiça Internacional (CPJI) ${ }^{63}$. Sua concepção é a de uma realidade já bastante alterada. Os próprios princípios norteadores da Sociedade das Nações e da ONU são fundamentalmente diversos e impactam (ou devem impactar) a leitura do dispositivo e da compreensão das fontes de direito internacional. A Carta da ONU é um documento que afirma, em primeiro plano, a função primordial dos Estados por promover, de maneira cooperativa, os direitos humanos - em contrapartida, o Pacto da Sociedade das Nações focava-se na manutenção da paz e da segurança como objetivos (no caso da ONU, são verdadeiros meios).

Por sua vez, uma perspectiva pautada na cooperação para a promoção dos direitos fundamentais deve se preocupar menos com o poder superior coator e mais com a efetividade de sua atuação. Seu foco privilegia a promoção dos valores eleitos e a ação efetiva dos Estados, desejando a adesão e o consenso e legando o uso da força à última instância.

A noção de cooperação existe no ambiente de uma comunidade internacional e pressupõe determinada caracterização do conceito de soberania. No esteio das ideias já referidas ao abordar o posicionamento de Peter Häberle e de Anne-Marie Slaughter,

\footnotetext{
${ }^{61} \mathrm{O}$ mais importante é a promoção de um direito e não a sua justificação.

${ }^{62}$ ALVAREZ, José E. International organizations as law-makers, p. 48.

${ }^{63}$ Conforme ensinam os professores Accioly, Nascimento e Silva e Casella: "Em reconhecimento ao monumental trabalho realizado pela CPJI, foi decidido que o projeto da nova Corte deveria ser ou a adaptação do Estatuto da CPJI, mantida em vigor com as modificações julgadas necessárias, ou novo Estatuto para cuja redação deveria servir de base o da CPJI. Esta última opção acabou por prevalecer: [...]" (ACCIOLY, Hildebrando; NASCIMENTO E SILVA; G. E. do; CASELlA, P. B. Manual de direito internacional público. 18. ed. São Paulo: Saraiva, 2010. p. 422).
} 
entende-se viável afirmar que a soberania pode ser encarada como o poder-dever dos Estados, ou seja, a soberania existe em virtude da promoção dos direitos fundamentais dos indivíduos. Dessa perspectiva, nega-se a ideia de soberania como conceito estático, para a qual a cooperação implica a interferência externa em questões internas - ainda que por ato volitivo prévio do Estado demandado. Trata-se, nesse sentido, não de entender a insuperável necessidade de o Estado cooperar ou acatar as decisões de uma organização internacional pelo viés do enfraquecimento de sua soberania ou por limitação de suas possibilidades de se negar a tanto; ao contrário, há o fortalecimento de sua soberania à medida que a participação cooperativa promove as suas finalidades - promoção dos valores fundamentais com que o Estado (soberania) está comprometido. Com isso, compreende-se de maneira positiva a importância das interações estatais na afirmação da soberania estatal, enquanto instrumento para a realização de valores universais.

Desse ponto de vista, os poderes de uma organização internacional são poderes instituídos; podem ser criados de modo explícito, no tratado de constituição, ou de modo implícito. Tanto em um caso como no outro, são atribuídos pelos Estados e se relacionam com as finalidades de cada organização. Em qualquer perspectiva, ademais, os poderes das organizações internacionais são conferidos e delimitados pelos Estados - daí que não se possa dizer que as organizações internacionais lhes sejam superiores de alguma maneira. Não há completa derrogação de soberania.

Convém mencionar, a esse respeito, que a doutrina reconhece a existência de um princípio que pode ser chamado de princípio da especialidade. Esse princípio consiste, conforme ensina João Manuel de Campos, na ideia de que uma organização é criada por ato volitivo para atendimento de objetivos definidos, e que os "particularismos de seu regime jurídico e a extensão das suas competências justificam-se e definem-se em função desses objetivos" $" 64$.

Os poderes que forem expressamente definidos o serão, portanto, em decorrência do princípio da especialidade e com base nele serão deduzidos os poderes implícitos. Isso porque, como o tratado de criação de uma organização internacional nem sempre é capaz de descrever em pormenores todas as competências, há sempre margem para interpretação. Essa interpretação, contudo, deve respeitar o "domínio reservado dos Estados $" 65$.

\footnotetext{
${ }^{64}$ CAMPOS, João Mota et al. Teoria geral das organizações internacionais, p. 91.

${ }^{65}$ Ibid., p. 92.
} 
A ideia de domínio reservado dos Estados dá a dimensão de que a soberania estatal é que limita os poderes das organizações internacionais; além disso, é o ato volitivo de soberania estatal que confere poderes a essas organizações.

O princípio da especialidade faz que os poderes de uma organização internacional sejam interpretados segundo as suas finalidades. Do ponto de vista prático, essa observação conduz à percepção de que uma organização internacional é sempre criada em decorrência da necessidade específica dos Estados por lidarem com determinado problema no âmbito internacional. O exemplo clássico da ONU dá essa dimensão: uma organização necessária à manutenção da paz e, sobretudo, à promoção dos direitos humanos, suprindo uma necessidade notada no contexto destruidor da Segunda Guerra Mundial. Os poderes atribuídos à organização, por sua vez, são os que se considerou apropriados para a execução de suas funções. Nesse sentido, é dotada de poderes de ordem vinculante aos membros e até de intervenção, em determinadas circunstâncias, segundo decisão do Conselho de Segurança. Outras organizações detêm poderes mais limitados. Destaque-se, contudo, que este trabalho não tem como propósito sustentar que as organizações sempre detêm os poderes necessários para o perfeito desempenho de suas funções - de fato, a Sociedade das Nações demonstra ter fracassado também em função de um déficit de poder, e de inoperância. Mesmo assim, a observação prática aponta para uma relação lógica necessária entre poder e dever, no âmbito das organizações internacionais.

Desse ponto de vista jurídico, qualquer análise deve relevar a forte influência voluntarista, notadamente do positivismo jurídico. E para um positivismo clássico, o direito internacional tem como fonte exclusiva o consentimento voluntário de cada soberania estatal, tendo o artigo 38 da CIJ sido elaborado sob essa ótica, e sem mencionar os atos de organizações internacionais como fonte de direito internacional.

Como lembra José E. Alvarez ${ }^{66}$, da perspectiva do positivismo clássico, a missão de produção de padrões e soft law não é uma tarefa jurídica, porque esses elementos normativos não teriam caráter de direito. Esse tipo de aproximação, segundo essa escola, abalaria o conceito de obrigação legal e lançaria insegurança jurídica.

A ocorrência de mudanças de paradigma conduziu a um debate intenso sobre o voluntarismo no direito e no direito internacional. Há um visível movimento de restauração

${ }^{66}$ ALVAREZ, José E. International organizations as law-makers, p. 49. 
axiológica do direito, que se apresenta como um contramovimento ao positivismo puro clássico. Essa ideia é apresentada pelo professor Fábio Konder Comparato ${ }^{67}$, ao asseverar:

\begin{abstract}
A bem dizer, o avanço ético faz-se sempre por reação a esses períodos de avania social. A cada grande surto de violência aniquiladora, os homens recuam, horrorizados, à vista da ignomínia, e compreendem afinal o sentido da dignidade humana. É a confirmação da sabedoria expressa pela máxima grega: sofrer para compreender (too patheimathos).
\end{abstract}

Nesse contexto, visões construtivistas do direito ganharam relevância ${ }^{68}$, com o aparecimento do que José E. Alvarez identifica como uma nova geração de institucionalistas, que valoriza o diálogo entre a teoria das relações sociais e o direito. Sobre essa base, pode-se pensar que as organizações servem, como se disse, para a promoção de valores e a solução de problemas determinados que não o poderiam ser por um Estado agindo isoladamente - pelo menos não com a mesma eficiência. Dessa perspectiva, a criação de uma organização internacional insere-se no contexto da cooperação internacional, mas assumindo também uma função de produtora de direito inovação sobre o artigo 38 do Estatuto da CIJ. Pode ser, portanto, encarada como um facilitador da cooperação, mas com poderes decorrentes de sua finalidade e do próprio princípio cooperativo que a anima, que a tornam, inclusive, instância produtora de instrumentos normativos com alto grau de legitimidade destinados a resolver problemas globais.

\title{
2.3 Os Atos da OCDE e sua Tipologia
}

Toda organização internacional retira competências de sua Carta criadora, conferidas pelos Estados. Essas competências podem ser explícitas, uma vez que expressamente mencionadas no texto, ou implícitas, quando decorrentes do princípio da especialidade. As competências, ademais, podem se referir ao funcionamento interno da organização, de modo que os atos praticados no exercício desse tipo de competência só

\footnotetext{
${ }^{67}$ COMPARATO. Fábio Konder. A humanidade no século XXI: a grande opção - Conferência pronunciada na Faculdade de Direito da Universidade de Coimbra, em 16 fev. 2000. Disponível em: <http://www.hottopos.com/convenit2/compara.htm>. Acesso em: 4 out. 2006.

${ }^{68}$ ALVAREZ, José E. International organizations as law-makers, p. 55: "The rise of constructivism in political science coincides with the end of the Cold War and the rise in confidence in policy circles in the power of such ideas as the free market, democracy, and human rights".
} 
geram efeitos nesse mesmo âmbito e entre os membros da organização. Pode ocorrer, contudo, que os atos das organizações passem a afetar não membros, em esfera que extrapole a ordem legal da organização.

José E. Alvarez ${ }^{69}$ lembra que o Conselho de Segurança tem poderes para praticar atos cujos efeitos efetivos podem ser direcionados a um Estado que não seja membro da organização; ademais, uma organização pode ter competências para expedir atos de caráter consultivo ou de recomendação que podem ser direcionados a não membros. No tocante à OCDE, vale lembrar que podem emanar decisões vinculantes e recomendações, conforme salienta José E. Alvarez:

The Council of the OECD, which comprises all of its 29 members, has the power to take both binding decisions and hortatory recommendations, but decisions must be based on a unanimous vote (although members are permitted to abstain, without precluding decisions from being adopted and becoming binding on others members ${ }^{70}$.

Outro aspecto dos atos das organizações internacionais que merece destaque refere-se aos sujeitos desses atos. Como regra, um ato de organização internacional, tomado como ato de direito internacional, dirige-se a outros sujeitos de direito internacional; no entanto, é possível que esses atos impliquem a subordinação de atores privados e indivíduos ${ }^{71}$. A esse propósito, importa frisar que os atos da OCDE relativos à Declaração sobre o Investimento Internacional e as Empresas Multinacionais é objeto de adesão estatal, mas acaba subordinando de modo bastante imediato a atuação de particulares.

De qualquer maneira, a doutrina, em rigor, sistematiza os atos de organização internacional partindo de um paralelo comum no estudo dos poderes estatais; no entanto, alguns elementos são somados para procurar atender mais especificamente às particularidades das organizações internacionais.

Os autores portugueses Margarida Martins e Afonso Martins, por exemplo, referem-se à função administrativa, política, normativa e jurisdicional ${ }^{72}$. Haverá, nesse sentido, uma caracterização do ato da organização, de acordo com a função que esteja

\footnotetext{
${ }^{69}$ ALVAREZ, José E. International organizations as law-makers, p. 62.

${ }^{70}$ Ibid., p. 117.

${ }^{71}$ CAMPOS, João Mota et al. Teoria geral das organizações internacionais, p. 102.

${ }^{72}$ MARTINS, Margarida Salema D’Oliveira; MARTINS, Afonso D'Oliveira. Direito das organizações internacionais, p. 268.
} 
desempenhando. É preciso, contudo, ter em mente que as categorias não podem ser consideradas de modo estanque; a função jurisdicional, por exemplo, também implica atividade normativa.

João Mota de Campos, também de Portugal, propõe uma sistematização que distingue os atos de natureza legislativa ou regulamentar - genéricos e obrigatórios; os atos administrativos diversos - sobre questões de funcionamento e administração da organização; os atos relativos às relações com os Estados-membros - como a admissão, por exemplo; e os atos de caráter consultivo e jurisdicional - adotados pelos órgãos de consulta ou tribunais.

Esse tipo de classificação - que certamente mereceria uma reflexão crítica não se mostra como o de maior interesse para o presente trabalho. Outra perspectiva apresenta-se, aqui, mais útil, pois, de fato, é possível observar que há uma espécie de ato que só interessa ao plano administrativo e interno das organizações internacionais; e há outro tipo de ato que interessa a sua relação com os Estados, podendo restringir-se aos membros, ou ampliar-se aos não membros, também. Veja-se, nesse sentido, que um ato que tenha caráter de solucionador de controvérsia pode ser de ordem interna ${ }^{73}$ ou externa daí o fato de ser chamado de jurisdicional não se mostrar tão relevante à análise que se propõe desenvolver neste trabalho.

Importa evidenciar a relação entre um direito da organização internacional que só interesse ao plano interno da própria instituição e outro que interesse ao plano externo que afeta a ordem jurídica de Estados-membros ou terceiros. Essa sistematização apresenta-se mais adequada para a delimitação do objeto deste trabalho, que se propõe a avaliar a afetação do Estado brasileiro e do direito pátrio no que tange a atos de uma organização internacional - a OCDE - da qual não é membro.

Outro aspecto que chama atenção, no que toca aos atos de organização internacional, é a potencialidade de vincular os Estados, apenas, e o de também ser diretamente aplicável nos territórios, gerando uma afetação das esferas de direitos dos particulares. O exemplo clássico é o caso europeu. A esse respeito, Karl Zemanek destaca não só a distinção do caso europeu no tocante à vinculação dos Estados-membros às decisões da organização, mas também no que tange à aplicação imediata das respectivas normas no âmbito interno:

\footnotetext{
${ }^{73}$ É o caso das sentenças de tribunais administrativos de organizações internacionais. Sobre o assunto, ver: DALLARI, P. B. de Abreu. Atualidades dos tribunais administrativos de organizações internacionais. 2009. Trabalho (Livre-Docência) - Universidade de São Paulo - USP, São Paulo, 2009.
} 
Only in the EC Pillar of the European Union do the Council and the Commission have powers to adopt regulations which are not only binding on the member States but directly applicable in their territories. Directives adopted by the same organ bind the member State with respect to the result which they must achieve through their own legislative action; directive become, however, directly applicable if a member State fails to implement them in the specified time ${ }^{74}$. (grifos do original)

No caso da OCDE, as Diretrizes formam um documento com ordens direcionadas a particulares; no entanto, são os Estados que assumem a obrigação de implementar essas diretrizes. O Brasil - que, conforme salientado, não é membro da OCDE - assumiu, por adesão à Declaração sobre o Investimento Internacional e as Empresas Multinacionais, o compromisso de implementar tais Diretrizes para Empresas Multinacionais. O País não produziu qualquer espécie normativa interna que reproduzisse as Diretrizes e, mesmo assim, assumiu que deveriam ser observadas pelas empresas. As questões a serem colocadas são: o Brasil agiu como se o ato da OCDE afetasse diretamente a atuação dos particulares? Essa postura é válida e comportada pelo ordenamento jurídico?

Trata-se de questões de difíceis respostas, cuja elucidação depende ainda da compreensão de vários aspectos da OCDE, da Declaração e das Diretrizes.

Por ora, interessa ao presente estudo compreender sucintamente os atos emanados pela OCDE. De modo geral, os principais tipos de atos estão previstos no artigo $5^{0}$ da Convenção de 1960. Ela trata das decisões que, salvo disposição em contrário, são vinculantes aos membros, das recomendações e dos acordos a serem celebrados com Estados-membros, não membros e organizações internacionais ${ }^{75}$; no entanto, há outras

\footnotetext{
${ }^{74}$ ZEMANEK, Karl. General course on public international law. R.C.A.D.I., t. 266, 1997-1998, p. 202. Tradução livre: "Somente no pilar da Comunidade Europeia, da União Europeia, o Conselho e a Comissão têm poderes para adotar regulamentos que não apenas vinculam os Estados-membros, mas que são diretamente aplicáveis em seus territórios. As diretivas aprovadas por tal órgão vinculam o Estado-membro em relação ao resultado que devem alcançar por meio de sua própria ação legislativa; a diretiva torna-se, no entanto, diretamente aplicável se um Estado-membro deixar de implementá-las no tempo especificado.”

75 Segundo o material informativo da OCDE: “The Organisation's governing body, the Council, has the power to adopt legal instruments, usually referred to as 'the OECD Acts'. These Acts are the result of the substantive work carried out in the Organisation's Committees. They are based on in-depth analysis and reporting undertaken within the Secretariat and cover a wide range of topics from Anti-Corruption to Environment.

The end products include international norms and standards, best practices and policy guidelines. Some of them, such as the Codes of Liberalisation, date back to the beginning of the Organisation.

Decisions are legally binding on all those Member countries which do not abstain at the time they are adopted. While they are not international treaties, they do entail the same kind of legal obligations as those subscribed to under international treaties. Members are obliged to implement Decisions and they must take the measures necessary for such implementation.
}

Recommendations are not legally binding, but practice accords them great moral force as representing the political will of Member countries and there is an expectation that Member countries will do their utmost to 
espécies, sobre as quais o embaixador Denis Fontes de Souza Pinto publicou obra, única da doutrina nacional, em que fez uma análise muito útil e eficaz do assunto ${ }^{76}$.

Nesse contexto, verifica que as decisões podem ter caráter interno ou externo, sendo as primeiras denominadas, ainda, resoluções. Já as decisões de ordem externa são aquelas que se aplicam aos Estados-membros, determinando os mecanismos de cooperação de caráter permanente e obrigatório.

A violação de uma decisão equivale, assim, à violação da própria Convenção da OCDE, com os reflexos que a violação do Direito dos Tratados, definido pela Convenção de Viena, trazem.

Importa relembrar que a OCDE não costuma delegar a cortes internacionais a solução de controvérsias envolvendo suas resoluções. Isso se deve à própria principiologia da Organização, que tem garantido especial legitimidade a suas normas e ações. Dessa maneira, o principal mecanismo de controle e sanção, no âmbito de suas normas, é de natureza política e moral.

Um último aspecto fundamental, sobre as características do sistema de Decisões da OCDE, é que esses atos geram a vinculação imediata do Estado-membro, não dependendo de nenhuma espécie de ratificação ${ }^{77}$ :

No plano interno, os países-membros não necessitam recorrer ao processo de ratificação, exigido de um tratado internacional, a não ser que assim o declare, quando da reunião do Conselho que aprovou o projeto de decisão. Segundo o artigo 5 da Convenção, o país-membro que aceita uma decisão tem a obrigação de pô-la em prática, em prazo razoável. [...]

fully implement a Recommendation. Thus, Member countries which do not intend to do implement a Recommendation usually abstain when it is adopted.

Other legal instruments are also developed within the framework of the Organisation:

Declarations: solemn texts setting out relatively precise policy commitments are subscribed to by the governments of Member countries. They are not formal Acts of the Organisation and are not intended to be legally binding, but they are noted by the OECD Council and their application is generally monitored by the responsible OECD body.

Arrangements and Understandings: instruments, negotiated and adopted in the framework of the Organisation by some Member countries. They are not Acts of the Organisation and are not legally binding, but they are noted by the OECD Council and their implementation is monitored.

International Agreements: concluded in the framework of the Organisation, they are legally binding on the Parties." (Disponível em: <http://www.oecd.org/document/46/0,3746,en_21571361_38481278_40899182 _1_1_1_1,00.html>. Acesso em: 27 nov. 2011.)

${ }^{76}$ PINTO, Denis Fontes de Souza. OCDE: uma visão brasileira, p. 59 e ss.

${ }^{77}$ Ibid., p. 25. 
Se a decisão contiver artigos de natureza facultativa - o que é possível -, então terá a denominação decisão recomendação ${ }^{78}$.

Por fim, importa mencionar que, embora os atos da OCDE objetivem diretamente os Estados-membros, a vocação universal da organização permite outras interações. Nesse sentido, é plenamente admissível a adesão de países não membros a decisões, ou a decisões recomendações. O regime a que estarão sujeitos esses aderentes equivale ao dos países-membros, exatamente como ocorre em relação aos países não membros participantes de comitês específicos - conforme será analisado com mais pormenores, adiante.

As recomendações são atos de natureza não vinculante, mas que possuem potencial de cobrança em face do comprometimento dos membros para adotar as medidas. Cabe aos Comitês específicos, nesse sentido, examinar as dificuldades na implementação das medidas e fazer sugestões. No tocante às recomendações, é salutar esclarecer:

\begin{abstract}
A aplicação da recomendação pode exigir a elaboração de nova legislação interna sobre a questão. Na maioria das vezes, entretanto, visa basicamente harmonizar práticas e procedimentos entre os países ou uniformizar métodos de interpretação. Em alguns casos, tem como finalidade encorajar empresas privadas a respeitar normas de conduta em território de país membro, como por exemplo, os princípios diretores das empresas multinacionais ${ }^{79}$.
\end{abstract}

Ao tratar dos demais atos, o embaixador Denis Fontes de Souza Pinto anota que a declaração ministerial se refere a uma verdadeira agenda. Os acertos têm caráter técnico, com regras detalhadas de conduta, e sua adoção, em rigor, acaba assumindo caráter informal. A principal finalidade dos avisos e relatórios, por fim, é facilitar a interpretação e a aplicação dos princípios e atos da $\mathrm{OCDE}^{80}$.

\footnotetext{
${ }^{78}$ Também na síntese do material informativo: "The Organisation's governing body, the Council, has the power to adopt legal instruments, usually referred to as 'the OECD Acts'. These Acts are the result of the substantive work carried out in the Organisation's Committees. They are based on in-depth analysis and reporting undertaken within the Secretariat and cover a wide range of topics from Anti-Corruption to Tax.

The main types of Acts are Decisions and Recommendations.

Other legal instruments are also developed within the framework of the Organisation such as Declarations, Arrangements and Understandings and International Agreements." (Disponível em: <http://webnet.oecd.org/oecdacts/>. Acesso em: 27 nov. 2011.) Também a esse respeito, ver: PINTO, Denis Fontes de Souza. $O C D E$ : uma visão brasileira, p. 59 e ss.

${ }^{79}$ PINTO, Denis Fontes de Souza. OCDE: uma visão brasileira, p. 30.

${ }^{80}$ De modo geral, os atos normativos da OCDE, como aqui comentados, podem ser assim sistematizados: decisões, resoluções, tratados, recomendações, declaração ministerial, acertos (arrangements), avisos e relatórios, comentários e esclarecimentos.
} 
Além desses atos, há os comentários do Comitê de Assuntos Fiscais relativos à aplicação e interpretação dos modelos de convenções fiscais da OCDE e os esclarecimentos do Cime (atual Comitê de Investimentos - CI) acerca dos princípios diretores atinentes a empresas multinacionais, que constituem compilações do entendimento compartilhado para países-membros sobre o alcance dos princípios. "Esses comentários e esclarecimentos emanados dos comitês servem também a expandir o alcance dessas normas, quando adotadas por países não-membros" ${ }^{\prime 81}$.

\subsection{A OCDE perante o Direito Brasileiro: Personalidade e Capacidade para a Prática de Atos}

No direito brasileiro, os atos jurídicos podem ser emanados de entes personalizados ou despersonalizados; tanto é assim que o Código Civil brasileiro, no artigo 104, utiliza a expressão agente capaz, preterindo outras mais restritivas, como pessoa capaz, por exemplo. De fato, o direito brasileiro reconhece a capacidade para a prática de atos jurídicos a entes despersonalizados como o condomínio e a massa falida, entre outros. No que tange à OCDE, organização internacional da qual o Brasil não é parte, e cujos atos pretende-se que gerem efeitos na ordem interna, entende-se apropriado resolver uma questão antes de avançar o estudo sobre seus atos: qual seria o fundamento para o reconhecimento da personalidade jurídica da OCDE, pelo Brasil, no plano do direito interno.

Conforme já investigado, a criação de uma organização internacional decorre de ato volitivo de pessoas jurídicas de direito internacional, que, pela celebração de um tratado, lhe atribuem personalidade. A esse propósito, além do direito costumeiro, aplicamse as normas da CVDT de 1969, conforme se pode verificar adiante. Pode-se dizer, de início, que o reconhecimento da personalidade jurídica de determinada organização internacional se dá, no plano internacional, pelo próprio ato de vinculação ao tratado de criação.

Saliente-se, que, contudo, as relações entre os Estados e as organizações internacionais - assim como entre os Estados - não se resume ao campo do direito internacional. No contexto interno de cada Estado, há relações estabelecidas que se

\footnotetext{
${ }^{81}$ PINTO, Denis Fontes de Souza. OCDE: uma visão brasileira, p. 33.
} 
submetem à ordem interna de um dos Estados e, nesse contexto, é lógico que haja um tratamento do direito interno sobre o reconhecimento da personalidade desses entes dotados de personalidade jurídica de direito internacional - até para que seja possível avaliar a validade e os efeitos dos atos jurídicos desses entes no âmbito interno.

No Brasil, o tratamento das pessoas jurídicas de direito público se dá por disposições do Código Civil (CC), pelos artigos 40 a 43. Esses dispositivos fixam o reconhecimento de duas categorias de pessoas jurídicas de direito público (internas e externas), classificando as internas e dizendo, a respeito das externas, que "São pessoas jurídicas de direito público externo os Estados estrangeiros e todas as pessoas que forem regidas pelo direito internacional público" (artigo 42 do $\mathrm{CC}$ ).

Pode-se considerar, portanto, ser esta a norma - artigo 42 - que orienta o reconhecimento da personalidade jurídica de entes de direito externo, pelo direito brasileiro. Assim, embora haja menções da Constituição Federal às relações com organizações internacionais (artigo 21, I, ou mesmo artigo 105, II, “c") ou dispositivo que permita deduzir o reconhecimento lógico da personalidade jurídica de determinada organização (artigo $5^{\circ}, \S 4^{\underline{0}}$ ), está na legislação civil a norma explícita pela qual a personalidade jurídica de um ente externo é incontroversamente reconhecida na ordem interna.

Esclarece-se que, todavia, o mencionado artigo 42 do Código Civil não se refere diretamente à organização internacional, mas apenas a Estados estrangeiros e "todas as pessoas que forem regidas pelo direito internacional público". Por essa disposição, a ordem jurídica interna delega integralmente à ordem internacional dizer o que tem e o que não tem personalidade jurídica de direito internacional. E conforme seja assim reconhecido, o direito brasileiro admitirá igualmente a personalidade.

É, no entanto, imperativo relembrar que o direito internacional ainda carrega intenso viés voluntarista, de modo que seria adequado dizer que é um ato do governo brasileiro que reconhecerá um novo Estado (por modo direto ou implícito) - ou deixará de reconhecê-lo; e, nessa linha, seria após a assinatura de um tratado de criação de organização internacional, com a sua vinculação, que o Brasil reconheceria a personalidade jurídica do ente criado -, pelo menos em uma primeira e mais estrita aproximação. 
A despeito de discussões sobre a adoção do monismo ou do dualismo, no direito brasileiro ${ }^{82}$, há um conjunto de normas de direito internacional, a respeito das quais se reconhece imperatividade - diferente da regra geral em termos de normas internacionais decorrentes de adesão voluntária dos Estados. A própria CVDT de 1969 lembra, no artigo 53, a existência dessa classe de normas imperativas, ou jus cogens. Referidas normas são de natureza fundamental, Higher Law, como os princípios atinentes aos direitos humanos, que dispensam qualquer ato volitivo do Estado para que sejam consideradas direito a ser observado.

Há, portanto, um tipo de direito internacional que dispensa qualquer formalidade interna para ser reconhecido como direito para o Estado, com efeitos lógicos na ordem jurídica nacional. Não se pode dizer, assim, que o reconhecimento do direito internacional pela ordem interna está condicionado necessariamente a atos formais de reconhecimento.

É possível que a literalidade do artigo 42 do Código Civil pátrio seja cotejada sob outros ângulos.

O primeiro, ainda em um contexto mais voluntarista, permitiria dizer que assim como o reconhecimento de um Estado dispensa qualquer iter procedimental envolvendo o Congresso Nacional, também o reconhecimento de uma organização internacional, como dotada de personalidade jurídica internacional, também o dispensaria, bastando, inclusive, que o Estado brasileiro agisse como reconhecedor.

O segundo, já mais afastado da doutrina voluntarista, e aparentemente mais compatível com o espírito prático das relações internacionais, relevaria o direito costumeiro. Se, por um lado, a CVDT propõe que um tratado não atingirá um Estado que dele não faça parte e, como se viu, nesses termos, o reconhecimento da personalidade jurídica de uma organização internacional dependeria da adesão do Estado à respectiva Carta, por outro, verifica-se que o direito costumeiro internacional induz ao reconhecimento da personalidade jurídica das organizações devidamente constituídas pelos terceiros Estados não vinculados à referida Carta - conforme tratado no item 1.3.

O artigo 42 do Código Civil brasileiro traz o fundamento de reconhecimento da personalidade das pessoas jurídicas de direito internacional, e que não depende, na verdade, da adesão brasileira ao tratado. Isso se dá, seja porque o reconhecimento da

\footnotetext{
${ }^{82}$ Destaque-se que a posição apontada é a que prevalece no âmbito do Supremo Tribunal Federal (STF), sem prejuízo da existência de opiniões relevantes divergentes. Nesse contexto, ver: DALLARI, P. B. de Abreu. Constituição e tratados internacionais. São Paulo: Saraiva, 2003. p. 13.
} 
condição de organização internacional dotada de personalidade é ato que dispensa o iter procedimental do artigo 49, inciso I, da Constituição Federal, seja porque o direito internacional retira, do direito costumeiro, a possibilidade de reconhecimento da personalidade de uma organização internacional, a despeito da adesão ao seu tratado constitutivo.

\subsection{Os Atos de Organização Internacional no Direito Brasileiro}

A participação do Estado brasileiro em um tratado de organização internacional seguirá, em rigor, o rito constitucionalmente previsto, com edição do Decreto presidencial de promulgação, ao final. Por consequência, as disposições que criem vinculação do Estado a normas e decisões emanadas pela organização internacional são igualmente recepcionadas, criando uma espécie de mandato. Em face disso, também, são legítimas as ações do Brasil, em âmbito interno, para a execução de decisões tomadas no seio das organizações de que faça parte - quando o tratado assinado, ratificado e internalizado assim prevê.

No caso da ONU, por exemplo, há duas realidades principais. A primeira é a relacionada às decisões da Assembleia Geral, cuja previsão do artigo 18 da Carta da ONU trata de recomendações, ou de questões de ordem interna da Organização. Não há, em rigor, nenhum tipo de decisão vinculatória dos Estados. Outro é o caso das decisões do Conselho de Segurança a respeito das quais, nos termos do artigo 25 da Carta, "os membros das Nações Unidas concordam em aceitar e executar as decisões do Conselho de Segurança, de acordo com a presente Carta”. Nesse sentido, ilustrativo o caso da Resolução no 1.970/2011 ${ }^{83}$, do Conselho de Segurança da ONU. Esse documento trata de vários assuntos relacionados ao regime do ditador Muammar Gadafi (ou Kadafi), ordenando a proibição de viagens e o congelamento de fundos de determinadas pessoas inclusive da família do ditador. Por meio de um Decreto - ato do poder executivo, portanto

\footnotetext{
${ }^{83}$ Decreto $\mathrm{n}^{\mathrm{o}}$ 7.460/2011, relativo à Resolução CS/ONU n.1970/2011: “O VICE-PRESIDENTE DA REPÚBLICA, no exercício do cargo de Presidente da República, usando da atribuição que lhe confere o art. 84, inciso IV, da Constituição, de acordo com o artigo 25 da Carta das Nações Unidas, promulgada pelo Decreto no 19.841, de 22 de outubro de 1945, e

Considerando a adoção da Resolução n⿳o 1.970 pelo Conselho de Segurança das Nações Unidas, em 26 de fevereiro de 2011, a qual, entre outras providências, estabelece o embargo de armas e a remessa da situação da Jamahiriya Árabe da Líbia ao Tribunal Penal Internacional, além de estabelecer proibição de viagens e congelamento de fundos de indivíduos especificamente designados; $[\ldots]$ ”.
} 
-, o presidente brasileiro à época, com fundamento em sua competência determinada pelo artigo 84, inciso IV, da Constituição Federal, bem como no dispositivo do artigo 25 da Carta da ONU, recepcionada pelo direito brasileiro consoante teor do Decreto $\mathrm{n}^{\mathrm{o}}$ 19.841/1945, estabeleceu a obrigatoriedade das autoridades brasileiras ao cumprimento dos termos de referida Resolução.

Verifica-se, in casu, que o fato de o Brasil já ter se obrigado nos termos da Carta das Nações Unidas, a qual foi formalmente recepcionada pelo direito brasileiro, induz à observância do seu artigo 25, o qual, por sua vez, determina que as decisões do Conselho de Segurança sejam acatadas pelos membros. Nesse sentido, a Resolução $\mathrm{n}^{\mathrm{o}}$ 1.970, a exemplo de outras, não se sujeitou ao procedimento congressual de internalização (artigo 49, I, da CF), e sua executoriedade deveu-se diretamente à adoção de seus termos por mero decreto presidencial.

Trata-se, portanto, do caso clássico em que o comando decorrente do ato de uma organização internacional extrai seu potencial de produção de efeitos internamente a partir da base lançada pela recepção do próprio tratado da organização internacional.

É imperativo mencionar, embora não diretamente ligado ao objeto central do presente trabalho, que as organizações internacionais também produzem atos concernentes à resolução de determinados conflitos - referidos como atos jurisdicionais. A relação desses atos com o direito brasileiro pode demandar um estudo específico e aprofundado, mas alguns aspectos servirão para ilustrar bem a perspectiva brasileira da relação entre direito interno e internacional nesse campo, e que poderá ser útil para a compreensão da cultura jurídica atual, na qual se insere a relação entre as Diretrizes e o direito brasileiro.

Nesse sentido, muito se pode observar da mais famosa casuística da relação entre o Brasil e as Cortes Internacionais: a referência é aos casos envolvendo os atos da Corte Interamericana de Direitos Humanos (CIDH) e do Tribunal Penal Internacional (TPI).

Anote-se, a esse respeito, que no caso do TPI há uma disposição expressa do artigo $5^{\circ}, \S^{\circ}$, da Constituição Federal, além da efetiva recepção nos termos do Decreto $n^{0}$ 4.388/2002. Ainda no que tange ao TPI, uma questão relativa aos efeitos dos seus atos em face da ordem jurídica brasileira tem especial relevância. É que o Brasil, comprometido a observar as decisões da Corte, estará obrigado à detenção e à entrega de quem solicitado, inclusive se nacional (artigo 59 do Tratado de Roma).

Surge, assim, uma questão relativa à distinção entre a entrega e a extradição. Isso porque a Constituição Federal recusa a extradição de nacional (artigo $5^{\circ}$, LI, da CF) e, 
por esse motivo, a eventual ordem do Tribunal dirigida ao Estado brasileiro, para que detenha e entregue nacional, teria suposta inconstitucionalidade.

Na verdade, os conceitos envolvidos no problema são objeto da Petição 4.625, oferecida perante o STF. O caso trata do pedido de detenção e entrega de Omar Al Bashir, sujeito à jurisdição do Tribunal por conta de atos praticados na presidência do Sudão ${ }^{84}$. Nesse contexto, o STF indica distinguir a entrega da extradição, apontando para a provável solução da questão da suposta inconstitucionalidade retromencionada - de modo que o Brasil se sujeitaria ao pedido de entrega.

Seja como for, o TPI é uma organização internacional, dotada de personalidade, e que expede atos a cuja observância o Brasil está vinculado, embora algumas questões de ordem constitucional possam eventualmente ser suscitadas. A relação entre o TPI e o Estado brasileiro é efetiva e já foi, inclusive, problematizada nos termos da Petição 4.625 referida há pouco.

Já no tocante à CIDH, casos que culminaram com a condenação brasileira ao pagamento de indenizações, tal qual o de Ximenes Lopes e de Gilson Nogueira, marcaram a aceitação brasileira da jurisdição obrigatória, como bem lembrado pelo professor André de Carvalho Ramos ${ }^{85}$.

Anote-se que a Convenção relativa ao sistema interamericano de proteção aos direitos humanos foi recepcionada em momento anterior à Emenda Constitucional $\mathrm{n}^{\mathrm{o}}$ 45/2004. Essa emenda pretendeu resolver a questão sobre a equivalência à norma constitucional dos tratados em matéria de direitos humanos - equivalência essa que se pretendia deduzir da redação ao artigo $5^{\circ}, \S 2^{\underline{o}}$, da Constituição Federal ${ }^{86}$. Em sentido diverso, entendeu-se que a Convenção celebrada antes daquela emenda ( $\left.n^{\circ} 45 / 2004\right)$, em

\footnotetext{
${ }^{84}$ No caso, de Relatoria da Ministra Ellen Gracie, uma decisão proferida pelo Ministro Celso de Melo, em 17 de julho de 2009, lembra alguns elementos básicos do sistema, tal qual o caráter supraestatal desse organismo judiciário, a incidência do princípio da complementaridade (ou da subsidiariedade) sobre o exercício, pelo Tribunal Penal Internacional, de sua jurisdição, a obrigação geral de cooperação e auxílio que se impõe aos estados-partes do Estatuto de Roma (artigo 86), para enfim lançar a questão da distinção entre os institutos da entrega (surrender) e da extradição, que considera questão prejudicial pertinente ao reconhecimento, ou não, da competência originária do Supremo Tribunal Federal para examinar o pedido de cooperação internacional. Outros pontos são ainda relevados, todos em torno do seguinte tema: a compatibilidade de determinadas cláusulas do Estatuto de Roma em face da Constituição do Brasil. O $\S 4^{\circ}$ do artigo $5^{\circ}$ da Constituição, introduzido pela Emenda Constitucional nº 45/2004: cláusula constitucional aberta destinada a legitimar, integralmente, o Estatuto de Roma?

${ }^{85}$ RAMOS, André de Carvalho. A execução das sentenças da Corte Interamericana de Direitos Humanos no Brasil. In: CASELLA, P. B. et al. (Orgs.). Direito internacional, humanismo e globalidade - amicorum discipulorum liber: homenagem a Guido Fernando Silva Soares. São Paulo: Atlas, 2008.

86 “ $\$ 2^{2}$ - Os direitos e garantias expressos nesta Constituição não excluem outros decorrentes do regime e dos princípios por ela adotados, ou dos tratados internacionais em que a República Federativa do Brasil seja parte."
} 
rigor, se submete ao texto constitucional e, em caso de conflito com aquele, não prevalece. Esse foi mesmo o entendimento do STF no julgamento do RE $n^{\circ}$ 466.343-1.

Surge, nesse ponto, uma questão relevante sobre os efeitos das decisões da Corte Interamericana de Direitos Humanos sobre o direito interno. É que as decisões de natureza condenatória da Corte, que imputam ao Estado brasileiro dever de indenizar, devem ser obrigatoriamente cumpridas. No entanto, a Constituição brasileira prevê, no artigo 100, que os pagamentos devidos pelas Fazendas Públicas devem obedecer a uma ordem cronológica - salvo exceções que menciona. Referido dispositivo institui o precatório.

No caso das condenações da Corte Interamericana, os pagamentos determinados, pela forma e prazo nela especificados, mostram-se incompatíveis com o sistema preconizado pelo mencionado artigo 100 da Constituição Federal - mesmo assim, as decisões têm sido cumpridas ${ }^{87}$.

\footnotetext{
${ }^{87}$ O professor André de Carvalho Ramos explica que a simples justificação de descumprimento de obrigação - inclusive em prazo razoável - imposta pela Corte fundada em dispositivos constitucionais é "inócua", porque são compreendidos pela Corte como "meros fatos praticados pelo Estado" (RAMOS, André de Carvalho. A execução das sentenças da Corte Interamericana de Direitos Humanos no Brasil. In: CASELLA, P. B. et al. (Orgs.). Direito internacional, humanismo e globalidade - amicorum discipulorum liber: homenagem a Guido Fernando Silva Soares, p. 451-468). Disso resulta que a obrigação - sendo obrigação legal do Estado brasileiro - deva ser cumprida espontaneamente. No caso de Damião Ximenes Lopes, por exemplo, o Decreto n⿳ำ 6.185/2007 autorizou o cumprimento da Decisão, nos seguintes termos:
}

“DECRETO № 6.185, DE 13 DE AGOSTO DE 2007

Autoriza a Secretaria Especial dos Direitos Humanos da Presidência da República a dar cumprimento à sentença exarada pela Corte Interamericana de Direitos Humanos.

O PRESIDENTE DA REPÚBLICA, no uso da atribuição que lhe confere o art. 84, inciso IV, da Constituição, e

Considerando a sentença da Corte Interamericana de Direitos Humanos no caso Damião Ximenes Lopes;

Considerando a existência de previsão orçamentária para pagamento de indenização a vítimas de violação das obrigações contraídas pela União por meio da adesão a tratados internacionais de proteção dos direitos humanos;

\section{DECRETA:}

Art. 1ํㅜ Fica autorizada a Secretaria Especial dos Direitos Humanos da Presidência da República a promover as gestões necessárias ao cumprimento da sentença da Corte Interamericana de Direitos Humanos, expedida em 4 de julho de 2006, referente ao caso Damião Ximenes Lopes, em especial a indenização pelas violações dos direitos humanos aos familiares ou a quem de direito couber, na forma do Anexo a este Decreto.

Art. $2^{\underline{ }}$ Este Decreto entra em vigor na data de sua publicação.

Brasília, 13 de agosto de 2007; 186o da Independência e $119^{\circ}$ da República.

LUIZ INÁCIO LULA DA SILVA

Dilma Rousseff". 
Há, ainda, a questão das condenações de natureza não pecuniária, as quais podem envolver obrigações de fazer e de não fazer, como investigar, libertar, sancionar responsáveis etc.. Em um ou em outro caso, no entendimento do Professor André de Carvalho Ramos, é necessário o desenvolvimento de legislação específica (enabling legislation). Nesse sentido, de acordo com o Professor, seria ideal que as iniciativas legislativas procurassem instituir formas de cumprimento espontâneo e de concretização de comandos das decisões vinculantes ao Brasil - em especial das recomendações da Comissão, evitando-se as condenações ${ }^{88}$.

Uma última observação mostra-se pertinente: as decisões de organizações internacionais, ainda que assumam essa natureza de sentença, nunca estão sujeitas à homologação pelo STF, porque são atos de direito internacional. Ao contrário, a homologação de sentença estrangeira é procedimento reservado às sentenças proferidas por órgãos jurisdicionais de outros Estados, exclusivamente, que são atos de outras soberanias.

${ }^{88}$ RAMOS, André de Carvalho. A execução das sentenças da Corte Interamericana de Direitos Humanos no Brasil. In: CASELLA, P. B. et al. (Orgs.). Direito internacional, humanismo e globalidade - amicorum discipulorum liber: homenagem a Guido Fernando Silva Soares, p. 451-468. 


\section{CAPÍTULO 3}

\section{RELAÇÕES BRASIL-OCDE E VINCULAÇÃO ÀS LINHAS DIRETRIZES DA OCDE PARA AS EMPRESAS MULTINACIONAIS}

\subsection{Participação de Não Membros nas Atividades da OCDE}

Conforme salientado, o Brasil não é membro da Organização para Cooperação e Desenvolvimento Econômicos (OCDE), embora tenha praticado uma política de aproximação que o levou a participar ativamente de suas atividades a partir de 1997. A compreensão do conjunto de relações estabelecidas - de modo não uniforme e por vezes atípico - entre a OCDE e o Estado brasileiro é caminho necessário para a compreensão das questões relacionadas à implementação das Diretrizes no Brasil, conforme será analisado detalhadamente adiante. Além disso, ela passa necessariamente, e com relevante proveito teórico, pela compreensão dos níveis de participação admitidos pela OCDE, e de como esse assunto evoluiu internamente na Organização.

A esse propósito, vale salientar que a OCDE é uma instituição de identidade muito definida, cujas ações são estritamente orientadas pelo seu mandato; contudo, seus objetivos - de natureza econômica - foram repensados de um contexto no início europeu (OECE) para um contexto global. Essa ampliação de horizontes também demandou uma ampliação de relações.

Em uma primeira aproximação pode-se imaginar que a ampliação mencionada se dá pela inclusão de novos membros, mas essa inclusão é a última etapa da cadeia. O propósito é criar uma aproximação, uma compatibilização de princípios para só então haver o efetivo ingresso do novo membro. Esse metódico processo de intensificação gradual do relacionamento visa proteger as bases de uma Organização que surgiu para perpetuar métodos e um grau de comprometimento rigoroso entre seus participantes. Isso justifica que o assunto da participação de não membros deva ser objeto de zeloso tratamento.

Além do exposto, a posição da OCDE, como uma organização de destaque e geradora de conhecimento sobre o contexto econômico global, induz ao necessário 
estabelecimento de relações com Estados não membros. Há muitos assuntos que são debatidos internamente na OCDE e que podem se beneficiar da participação mais próxima de um representante de determinado Estado ou organização que viva a experiência direta daquele assunto.

Seja como for, a participação de não membros nas atividades da OCDE decorre do texto da Convenção de sua criação, assinado em Paris, em 14 de dezembro de 1960. Segundo esse texto, mais precisamente pela norma estabelecida pelo artigo 12, alínea "c", de acordo com as condições determinadas pelo Conselho da Organização, ela poderia convidar Estados não membros e organizações para participar de suas atividades.

De fato, o artigo 12 da Convenção da OCDE é seguido e regulamentado pelas Regras de Procedimento ${ }^{89}$ (artigo 9, “a”) ${ }^{90}$, cuja redação permite concluir que o Conselho tem, de fato, esse mandato para convidar não membros à participação.

Diante da questão atinente à possibilidade de participação de outros entes que não apenas Estados soberanos, produziu-se, no âmbito do Conselho, uma Resolução. A referida Resolução C(98)211, à qual havia sido dado o caráter de confidencial, tem o seguinte título: Participation of Non-Members in the Activities of the Organization: Legal Aspects of the Issue ${ }^{91}$, e o documento suscita outro argumento valioso para o reconhecimento do poder do Conselho para convidar qualquer pessoa física ou jurídica.

Com isso, considera que a disposição do artigo 12 não é, por si só, nem suficiente, nem o necessário elemento justificador, para possibilitar o convite a pessoas naturais ou jurídicas. O documento objeto de análise suscita a ideia de que não seria necessário que um instrumento constitutivo de organização internacional contivesse uma provisão específica nesse sentido, para que esse poder de convite à participação fosse

\footnotetext{
${ }^{89}$ Segundo o preâmbulo: "The Rules of Procedure of the Organization were adopted by the Council on 30 September 1961 [OECD/C(61)21] and amended since that date by the Resolutions of the Council of 24 July 1962 [C(62)115(Final)], 24 July 1965 [C(65)87], 29 September 1970 [C(70)133(FINAL)] and 17 April 2008 [C(2007)14/FINAL]." Tradução livre: “As Regras de Procedimento da Organização foram adotadas pelo Conselho em 30 de setembro de 1961 [OECD/C(61)21] e emendadas a partir de então pelas Resoluções do Conselho de 24 de julho de 1962 [C(62)115(Final)], de 24 de julho 1965 [C(65)87], de 29 de setembro de 1970 [C(70)133(Final)] e de 17 de abril de 2008 [C(2007)14/FINAL]."

90 "Rule 9: a) The Council may invite a non-Member or an international organisation to be represented by an observer at meetings, or parts of meetings, of all or certain bodies of the Organisation." Tradução livre: "Regra 9: a) O Conselho deve convidar um não membro ou uma organização internacional para ser representada por observadores em uma reunião, ou partes de reunião, de todos ou de alguns órgãos da Organização."

91 Tradução livre: "Participação de Não membros nas Atividades da Organização: Aspectos Legais da Questão."
} 
possível. Denota-se, aqui, provável alusão ao poder decorrente da natureza institucional e da persecução da finalidade da organização.

Daí a Resolução concluir, sem espaço a dúvidas, que o Conselho poderia, como de fato pode, decidir livremente sobre a pessoa natural ou jurídica que deve participar das atividades da Organização, tanto quanto determinar as condições que devem ser atendidas ${ }^{92}$.

É pertinente salientar que o documento trata também de uma questão muito relevante, qual seja, o alcance dos efeitos de um ato internacional - considerados interpretativos. Para tanto, inicia a construção do raciocínio aludindo à disposição da CVDT, mais especificamente o teor do no artigo 31. Nesse sentido, são lançadas as bases da boa-fé na interpretação dos tratados, segundo seu objetivo e finalidade.

Amparado nessas bases do primeiro parágrafo do artigo $31^{93}$, e ainda mencionando os parágrafos segundo e terceiro, o documento conclui que a Resolução C(96)64/REV1/FINAL consiste em uma interpretação autêntica da Convenção da OCDE, vinculando todos os envolvidos. Vale dizer, o parágrafo terceiro, do artigo 31, da Convenção de Viena alude à necessidade de se considerar, no processo de interpretação de um tratado, qualquer acordo ou prática entre as partes ou regras de Direito Internacional aplicáveis à relação como meio para se definir a interpretação do tratado. E, a partir disso, o documento recorre ao entendimento da Comissão de Direito Internacional para reconhecer que

[...] an agreement as to the interpretation of a provision reached after the conclusion of the treaty represents an authentic interpretation by the

\footnotetext{
${ }^{92} \mathrm{C}(98) 211: 8$. "This means that the Council is free to decide which natural or legal persons may participate in the activities of the Organization, as well as to determine the conditions on which they may do so." Tradução livre: "Isso significa que o Conselho é livre para decidir quais pessoas naturais ou jurídicas participarão das atividades da Organização, assim como para determinar as condições em que elas se darão.”

93 Artigo 31: Regra Geral de Interpretação: “1. Um tratado deve ser interpretado de boa-fé segundo o sentido comum atribuível aos termos do tratado em seu contexto e à luz de seu objetivo e finalidade.
}

2. Para os fins de interpretação de um tratado, o contexto compreenderá, além do texto, seu preâmbulo e anexos: a) qualquer acordo relativo ao tratado e feito entre todas as partes em conexão com a conclusão do tratado; b) qualquer instrumento estabelecido por uma ou várias partes em conexão com a conclusão do tratado e aceito pelas outras partes como instrumento relativo ao tratado.

3. Serão levados em consideração, juntamente com o contexto: a) qualquer acordo posterior entre as partes relativo à interpretação do tratado ou à aplicação de suas disposições; b) qualquer prática seguida posteriormente na aplicação do tratado, pela qual se estabeleça o acordo das partes relativo à sua interpretação; c) quaisquer regras pertinentes de Direito Internacional aplicáveis às relações entre as partes.

4. Um termo será entendido em sentido especial se estiver estabelecido que essa era a intenção das partes." 
parties which must be read into the treaty for purpose of its interpretation $^{94}$.

A Resolução C(96)64/REV1/FINAL - o documento então vigente -, intitulada Resolution of the Concil Concerning the Participation of Non-member Economies in the Work of Subsidiary Bodies of the Organization ${ }^{95}$, é, assim, considerada uma linha interpretativa válida para a Convenção da OCDE. Desse modo, e com amparo no mandato implícito da OCDE, no texto expresso do artigo 12 da Convenção da OCDE, assim como no artigo 9 das Regras de Procedimento, admite-se, agora de forma definitiva, que a participação de não membros nas atividades da OCDE abrange Estados soberanos, além de outras pessoas físicas e jurídicas ${ }^{96}$.

Seja como for, a Convenção da OCDE possui um fundamento legal compatível com o mandato implícito de uma organização internacional, para permitir o relacionamento participativo com não membros - inclusive os que não sejam Estados soberanos. Ademais, as Regras de Procedimento da OCDE, adotadas pelo Conselho, são sua expressão legítima, decorrendo de um poder reconhecidamente atribuído ao Conselho, de forma especial, para definir o regulamento para a participação dessas pessoas que não sejam membros nas atividades da OCDE. Trata-se do poder da organização de produzir normas jurídicas sobre a sua organização interna, no cumprimento das finalidades da organização (cooperação) $)^{97}$.

\footnotetext{
${ }^{94}$ YEARBOOK of the International Law Comission, 1966. v. II, p. 41, Parágrafo 14, cuja tradução livre é: "um acordo para a interpretação de uma previsão obtido após a conclusão de um tratado representa uma interpretação autêntica das partes que deve ser lida no tratado para os propósitos de sua interpretação".

95 Tradução livre: "Resolução do Conselho concernente à Participação de Economias Não Membros nos Trabalhos dos Órgãos Subsidiários da Organização”.

${ }^{96} \mathrm{C}(98) 211: 20$. Consequently, the Secretary-General invites the Council to adopt the folowing draft entry in its summary record: THE COUNCIL a) noted document $\mathrm{C}(98) 211$; b) confirmes that the OECD Convention does not restrict the participation of non-members in activities of the Organization solely to sovereign States and that in particular Resolution C(96)64/REV1/FINAL - which constitutes an authentic interpretation of the relevant provisions of the Convention - explicitly encompasses the participation of non-member countries or economies in the subsidiary bodies of the Organization without any implied bearing as to the legal and political status of the economy concerned. Tradução livre: "Conseqüentemente, o Secretário-Geral convida o Conselho a adotar o seguinte projeto em seu registro de resumo: O CONSELHO a) anotado o documento C (98) 211 ; b) confirma que a Convenção da OCDE não restringe a participação de não membros em atividades da Organização em relação somente aos Estados soberanos e que, na Resolução C (96) 64/REV1/FINAL que constitui uma interpretação autêntica das disposições pertinentes da Convenção - explicitamente abrange a participação de terceiros países ou economias em órgãos subsidiários da Organização, sem qualquer influência implícita em relação ao estatuto jurídico e político da economia em causa."

${ }^{97}$ Vale lembrar que, a despeito da uma posição clássica, atualmente se reconhecem duas dimensões do direito que emana da organização internacional: "Deux conceptions de cet ordre juridique sont possibles. Deux conceptions de cet ordre juridique sont possibles. D'après la première, le droit interne concerne exclusivamente les règles relatives aux structures et au foctionnement de l'organization internationale: règlements internes des organes, du personnel, crèation d'organes, etc. [...] Cepedant, rien ne justifie
} 
Por fim, é oportuno destacar que, após os documentos C(96)64/REV1/FINAL e C(98)211, o assunto retornou à pauta do Conselho, e o documento C(96)64/REV2/FINAL, datado de setembro de 2000, sob o título Resolution of the Council Concerning the Participation of Non-Members Economies in the Work of Subsidiary Bodies of the Organization foi sucedido pelo documento C(2004)132/FINAL, de agosto de 2004, denominado Resolution of the Council Concerning the Participation of NonMembers in the Work of Subsidiary Bodies of the Organization ${ }^{98}$, que atualmente regulamenta o assunto.

\subsection{A Regulamentação Atual: Resolution of the Council Concerning the Participation of Non-Members in the Work of Subsidiary Bodies of the Organization (C(2004)132/FINAL)99}

O fundamento normativo para a Resolução está no artigo 12 da Convenção da $\mathrm{OCDE}^{100}$. Esse é o dispositivo que trata do mandato da Organização para estabelecer relações com os Estados não membros ou organizações e convidá-los a participar de atividades da Organização.

Essa Resolução deve ser compreendida no contexto de ampliação da Organização, ao lado do propósito de divulgá-la. Importa frisar, a esse respeito, que esse

théoriquement l'exclusion de normes destinées à influencer le comportement de ses sujets et particulièrement des Etats membres en vue de la réalisation des buts pour lesquels une organisation a été créée. [...]". Tradução livre: "Duas concepções desta ordem jurídica são possíveis. De acordo com a primeira, o direito interno concerne exclusivamente às regras de estruturas e funcionamento da organização internacional: regulamentos internos dos órgãos, dos funcionários, criação de organismos etc. [...] Contudo, teoricamente, não há justificativa para a exclusão desse contexto das normas de influência do comportamento dos sujeitos, especialmente, os Estados-Membros, para alcançar os fins para os quais uma organização foi criada.” (CAHIER, Philippe. L'ordre juridique interne des organisations internationales. In: DUPUY, René-Jean (Ed.). Manuel sur les organizations internationales. The Hague Academy of International sur les Organization Internationales. Hague Academy of International Law Hage (Des Cours - Colloques, 87), p. 388).

${ }^{98}$ Igualmente, a tradução livre é: "Resolução do Conselho concernente à Participação de Economias Não Membros nos Trabalhos dos Órgãos Subsidiários da Organização".

${ }^{99}$ Idem: preferiu-se manter a nomenclatura oficial, no idioma inglês, no corpo do texto, porque é assim que o documento efetivamente é identificado.

100 "Article 12. Upon such terms and conditions as the Council may determine, the Organisation may: (a) address communications to non-member States or organisations; (b) establish and maintain relations with non-member States or organisations; and; c) invite non-member Governments or organisations to participate in activities of the Organisation." Tradução livre: "Artigo 12. Nos termos e condições que o Conselho determinar, a Organização pode: (a) Endereçar comunicação para Estados não membros ou organizações; (b) Estabelecer e manter relações com Estados não membros ou organizações; e c) convidar governos de não membros ou organizações para participar das atividades da Organização." 
objetivo de ampliação tem dois sentidos: o primeiro, reforçar a qualidade do trabalho da Organização, pela colaboração externa; e, o segundo, levar adiante o projeto da Organização em termos de moldar a ordem econômica mundial e promover o desenvolvimento, de modo geral.

Como é elemento característico da OCDE, herança da então Organização Europeia de Cooperação Econômica, os mecanismos de avaliação e supervisão constituem um ponto fundamental a ser zelado nas atividades da Organização. Daí que a Resolução tenha se preocupado, de forma central, com a organização dos processos de admissão, supervisão e avaliação da participação de não membros. Tudo isso, é claro, com o fim de se manter o padrão de efetividade e, especialmente, avaliar os não membros selecionados como potenciais futuros membros.

Sobre as regras trazidas pelo documento, elas se organizam em um texto de doze pontos, contendo a Decisão, que adota dois Anexos. O primeiro Anexo é designado Guidelines for Subsidiary Bodies on the Development of a Pro-active Strategy for the Participation of Non-Members e, o segundo, Guidelines on Participation by Non-Members in the Work of Subsidiary Bodies of the Organization. Ou seja, o primeiro Anexo traz as regras e os procedimentos para a participação (convite-ingresso), enquanto o segundo trata das normas atinentes à participação em si. A decisão, por sua vez, é um texto de caráter mais amplo e principiológico, que se encontra traduzido em termos mais práticos pelos respectivos anexos. Conforme será verificado com mais detalhes adiante, é a Decisão que determina sob que possibilidades de tipificação a participação de não membros é possível, cabendo ao Anexo I descrever o que cada forma de participação significa.

O Anexo I, conforme adiantado, trata, por assim dizer, das regras para a admissão, determinando quais os valores a serem considerados para que um convite seja tido por apropriado. De modo geral, os critérios revelam a preocupação central com a contribuição que o convidado pode trazer à Organização, aos seus valores e ao cumprimento de seu mandato. Há menções a respeito do grau de quanto a participação do não membro pode beneficiar o mandato e o programa de trabalho do órgão subsidiário, do grau de benefício que a associação com o não membro pode trazer para a Organização, do nível de influência da riqueza ou do crescimento econômico dos membros por aquele não membro enquanto o know-how do não membro pode acrescentar ao processo de produção normativa. 
Existem ainda os critérios práticos, como os que relevam a relação entre a quantidade de membros e não membros em determinado órgão, ou mesmo as consequências para a aplicação de métodos de trabalho.

De modo geral, pode-se sintetizar esse Anexo por um valor enunciado na última das alíneas ${ }^{101}$. Trata-se de clara menção à aplicação das estruturas da Organização no que concerne à participação de não membros de modo a maximizar benefícios e mitigar desvantagens.

Sem tom de crítica ou elogio, mas de mera observação científica, é importante anotar que o convite a um participante não membro é julgado conveniente ou inconveniente não segundo o critério dos interesses ou benefícios individualmente tomados, mas sim do ponto de vista dos objetivos da organização, denotando, mais uma vez, a orientação conceitual muito marcante da Organização. O objetivo de maximização de benefícios, com a melhor aplicação de cada recurso e estrutura, também denota traduzir bem a OCDE.

O Anexo II, por sua vez, trata da forma de participação em si, dos não membros. Esse texto aborda as formas de possível cooperação e da participação em sessões oficiais de órgãos subsidiários.

Sobre as formas de possível cooperação, o texto do Anexo II indica que o órgão deve buscar a melhor forma de relação, que pode ser a participação em atividades específicas, abertas pela Organização para não membros, ou a participação direta em sessões oficiais como observador ad hoc, observador regular, ou mesmo como participante pleno. Admite-se, ainda, outra forma de cooperação que se mostre apropriada.

Os observadores ad hoc têm atuação mais restrita, para reuniões específicas, e para as quais possa contribuir com a discussão. Já os observadores regulares são admitidos para assistir as reuniões de um órgão subsidiário - mas não necessariamente aqueles em nível Ministerial, ou mesmo que envolvam outros órgãos e seus órgãos subsidiários -, com o compromisso de colaborar ativamente para os trabalhos. Destaque-se que o observador regular guarda essa condição a título precário, havendo menção expressa à possibilidade de sua suspensão, inclusive em caso de não pagamento de taxas devidas - já que cabe ao observador regular contribuir financeiramente com a Organização.

101 "[...] h) a consideration of the full range of vehicles to engage non-Members in the work of the Organization and the subsidiary body concerned, as well as the limits and forms of the participation of nonMembers which appear desirable and most useful, to maximize the benefits and reduce any disadvantages." 
Já o participante pleno é uma condição reservada aos não membros capazes de corresponder à disciplina da Organização, com contribuições muito mais relevantes do que a de um observador. O participante pleno deve aderir aos instrumentos que formam a base de trabalho do órgão subsidiário e estão obrigados a colaborar plenamente com os trabalhos do órgão de que participam, inclusive com a troca de informações. Destaque-se, sob esse último aspecto, a natureza da Organização quanto à formulação de políticas estratégicas, em que o trânsito de informações confidenciais é um aspecto que merece destaque especial.

E, como não poderia ser diferente, o não membro participante pleno deve fazer contribuições compatíveis com a sua condição para a manutenção do órgão de que participa, e sua relação não é precária como a do não membro observador, muito embora possa ser suspenso ou excluído sob fundamentos razoáveis.

Os participantes plenos tomam parte nas atividades de seus órgãos subsidiários como se fossem membros, mas nunca participam de assuntos que envolvam as relações da Organização com os não membros.

Enfim, a identidade da OCDE é bastante definida e bem-expressa, inclusive em suas normas atinentes à participação de não membros. A natureza da Organização ressalta o interesse coletivo representado pela própria OCDE, legando os interesses individuais de cada Estado a uma consequência. Daí, certamente, que a participação de um não membro dependa e esteja orientada mais para a contribuição que essa participação possa dar ao conjunto, decorrendo do resultado dessa cooperação o atendimento aos interesses do Estado.

\subsection{Do Estabelecimento de Relações entre A OCDE e o Brasil, um Não Membro}

O embaixador Denis Fontes de Souza Pinto relata, na obra OCDE: uma visão brasileira, que a relação entre o Brasil e a Organização para Cooperação e Desenvolvimento Econômicos (OCDE) só se estabeleceu de modo relevante a partir da década de 1990. O marco da relação entre Brasil e OCDE teria sido a ida da Missão Brasileira à OCDE, em junho de 1991. Dentre as justificativas para se destacar esse momento, estão tanto a "eleição de novo governo no Brasil comprometido com o 
aprimoramento das relações com o Primeiro Mundo"102 quanto a intenção manifesta da OCDE em promover sua abertura para a relação com novos Estados.

Ainda segundo o diplomata, essa primeira aproximação teria o propósito de coletar informações que permitissem refletir um modo de iniciar relações, sem se objetivar a finalidade de ingresso como um membro da Organização. Ademais, pensou-se em áreas nas quais a participação seria mais interessante e acessível, excluindo-se, por exemplo, "em um primeiro momento, aquelas áreas nas quais teria de assumir obrigações legais, que não estava em condições de cumprir" ${ }^{\prime 103}$. Privilegiou-se, portanto, o início de uma relação gradual, com maior troca de informações e prestigiando-se o conhecimento mútuo, sem a assunção de obrigações legais de maior impacto.

É relevante, ainda, compreender o momento brasileiro sob mais um enfoque. Em 1995, na gestão de governo do presidente Fernando Henrique Cardoso, foi aprovada, pelo Congresso Nacional, a Emenda $\mathrm{n}^{-0}$, que alterou dispositivos da ordem econômica. $\mathrm{O}$ inciso IX do artigo 170 foi alterado, e o artigo 171 foi revogado, sendo a redação, à época, dos dispositivos a seguinte:

\footnotetext{
Art. 170: [...]

IX - tratamento favorecido para as empresas brasileiras de capital nacional de pequeno porte.

[...]

Art.1 71. São consideradas:

I - empresa brasileira a constituída sob as leis brasileiras e que tenha sua sede e administração no País;

II - empresa brasileira de capital nacional aquela cujo controle efetivo esteja em caráter permanente sob a titularidade direta ou indireta de pessoas físicas domiciliadas e residentes no País ou de entidade de direito público interno, entendendo-se por controle efetivo da empresa a titularidade da maioria de seu capital votante e o exercício de fato e de direito, do poder decisório para gerir suas atividades.

$1^{0}$ - A lei poderá, em relação à empresa brasileira de capital nacional:

I - conceder proteção e benefícios especiais temporários para desenvolver atividades consideradas estratégicas para a defesa nacional ou imprescindíveis ao desenvolvimento do País;

$[\ldots]$
}

Com as mudanças, a distinção entre empresas de capital nacional e de capital estrangeiro, do artigo 171, desaparece; e, com relação ao artigo 170, inciso IX, o

\footnotetext{
${ }^{102}$ PINTO, Denis Fontes de Souza. OCDE: uma visão brasileira, p. 97: "De fato, conforme cita o autor, com a devida referência, o texto em destaque é parte da informação ao presidente da República, de 21 de novembro de 1990, assinada pelo então ministro de Estado, Francisco Rezek."

${ }^{103}$ Ibid., p. 99.
} 
tratamento favorecido passa a se referir a empresas de pequeno porte, seja qual for o seu capital, nos seguintes termos:

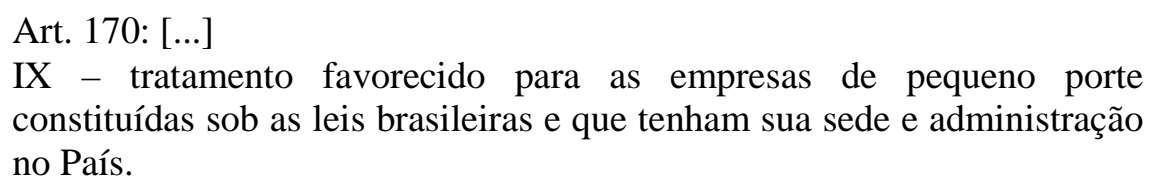
constituídas sob as leis brasileiras e que tenham sua sede e administração no País.

Sob essas novas regras, segundo as palavras de José Afonso da Silva, passa a haver

[...] empresas brasileiras e empresas não-brasileiras, com diferença exclusivamente formal entre elas, pois basta que a empresa estrangeira ou multinacional (ou parte dela) se organize aqui segundo as leis brasileiras e tenha sede aqui para ser reputada brasileira, pouco importando a nacionalidade de seu capital e a nacionalidade, domicílio e residência das pessoas que detêm o seu controle $[\ldots]^{104}$.

Essa reforma no texto constitucional ${ }^{105}$ mostra bem a dimensão da reorientação política do momento, mais compatível com as pretensões de inserção brasileira no contexto internacional e de efetiva abertura de sua economia. O objetivo declarado da emenda era eliminar a distinção entre empresa brasileira e empresa brasileira de capital nacional e o tratamento preferencial a esta concedido, com o fim de viabilizar a atração de investimentos estrangeiros para os setores de mineração e energia elétrica ${ }^{106}$. De fato, a própria Declaração menciona o compromisso do tratamento nacional - tratamento equitativo a todas as empresas atuantes em seu território, independentemente do seu capital.

No tocante à aproximação brasileira da OCDE, no contexto dessa reorientação política, o embaixador Denis Pinto indica que, em um primeiro momento, o governo definiu as áreas de interesse, em termos de participação nas atividades da Organização. Essas áreas eram, inicialmente, o Departamento Econômico, o Comitê de Revisão Econômica e de Desenvolvimento, o Comitê de Administração Pública, o Comitê de Meio Ambiente, o Comitê de Indústria e, de forma mais expressiva, o Comitê do Aço. Importa

\footnotetext{
${ }^{104}$ SILVA, José Afonso da. Curso de direito constitucional positivo. 16. ed. São Paulo: Malheiros, 1998. p. 772.

105 TRÂMITE da Emenda Constitucional n. 32/1995. Disponível em: <http://www.senado.gov.br/ atividade/materia/detalhes.asp?p_cod_mate=18480>. Acesso em: 15 nov. 2011.

${ }^{106}$ Mencionem-se, ainda, as privatizações das empresas concessionárias de serviços públicos.
} 
mencionar, a respeito do Comitê de Aço, que o Brasil já havia sido convidado a participar dele, em 1978, no momento de sua criação, embora não tenha levado adiante a ideia - o convite justificava-se já que era um país de relevante atividade siderúrgica.

A aproximação brasileira no que tange às atividades da OCDE deu-se, em 1992, em relação ao Comitê de Meio Ambiente, ao Comitê de Administração Pública e ao Comitê de Indústria, como observador regular; no tocante ao Comitê do Aço ${ }^{107}$, a OCDE admitiu que o Brasil o integrasse como participante efetivo, o que só ocorreria em 1996, após o processo de privatização do setor. É oportuno salientar, a esse propósito, que na Exposição de Motivos $n^{0}$ 425/1996, que conduziu a aprovação do Decreto Legislativo $n^{0}$ 33/1998 - aprovação congressual à integração do referido Comitê do Aço -, o diplomata Sebastião do Rego Barros aponta, dentre diversas outras razões, o fato de a aproximação pretendida com a OCDE encontrar ainda conformação plena da "legislação e (d)a política brasileiras relacionados com o setor siderúrgico nacional às diretrizes e aos objetivos do Comitê" ${ }^{\prime 108}$. Em 1994, foi aprovado o ingresso brasileiro como membro pleno do Centro de Desenvolvimento. Mencione-se também o envolvimento brasileiro em diversos seminários e reuniões, já nesse primeiro período, cuja continuidade é muitas vezes comprometida pela falta de estruturação e, em alguns casos, até pela "ausência de clara definição sobre a representação brasileira nessas reuniões"109.

A propósito do Comitê de Investimentos e Empresas Multinacionais (Cime), o Brasil passou a integrá-lo como observador a partir de 1997, após cerca de dois anos participando de algumas de suas atividades. Como destaca o embaixador Denis Fontes de Souza Pinto, esse é um Comitê de especial relevância para a OCDE, motivo pelo qual o ingresso como observador requer um processo mais rigoroso de seleção, implicando, inclusive, a necessidade de adesão à Declaração sobre Investimento Internacional $e$ Empresas Multinacionais ${ }^{110}$.

\footnotetext{
${ }^{107}$ PINTO, Denis Fontes de Souza. OCDE: uma visão brasileira, p. 101/102.

${ }^{108}$ BRASIL. Câmara dos Deputados. Diário da Câmara dos Deputados, 12 out. 1996, p. 26.564.

109 PINTO, Denis Fontes de Souza. Op. cit., p. 99: "No que diz respeito às providências práticas e administrativas que dariam respaldo à atuação brasileira na Organização, duas linhas de ação foram mencionadas: criação de núcleo na Embaixada em Paris e na Secretaria de Estado e estabelecimento de 'pontos focais na administração brasileira para estudo dos documentos e a participação nos trabalhos da OCDE'. Essas sugestões não foram, infelizmente, implementadas a contento, deficiência que tem em muito limitado, nos últimos anos, a atuação do Brasil na Organização e o efetivo aproveitamento do esforço empreendido e dos recursos alocados." Ver, ainda, ibid., p. 115.

${ }^{110}$ Ibid., loc. cit.
} 


\subsection{A Resolução da OCDE sobre Ampliação e Engajamento e o Contexto da Participação Brasileira}

Em maio de 2007, o Conselho da OCDE, em nível Ministerial ${ }^{111}$, adotou a Resolução C/MIN(2007)4/FINAL, denominada Council Resolution on Enlargement and Enhanced Engagement ${ }^{112}$. O documento insere-se no contexto de um processo para ampliação da Organização, fazendo referência a diversos outros documentos, como a Resolution to Estabilish a Mechanism to Identify Countries for Potential Accession and Countries for Enhanced Engagement with OCDE (C(2006)73/FINAL; C/M(2006)) e os Reports denominados A Strategy for out Reach and Enlargement (C(2004)60) e Enhanced Engagement: Report by the External Relations Committee $(\mathrm{C}(2007) 42)^{113}$. Faz, também, menção expressa à necessidade de se expandir o alcance global da OCDE, seu impacto político e sua relevância.

Dentre os pontos de que trata, está o processo já avançado de admissão de novos membros, nominalmente identificados, definição de novos espaços que merecerão atenção com a finalidade de obter novos integrantes e decisões de caráter financeiro.

Nesse contexto, importa que, logo no primeiro item de suas resoluções, o Secretario Geral convida a se fortalecer a cooperação com o Brasil, além de China, Índia, Indonésia e África do Sul, sempre objetivando uma possível preparação para o ingresso como membro ${ }^{114}$ da Organização.

Em artigo no jornal Valor Econômico ${ }^{115}$, o jornalista Cristiano Romero sintetiza importantes aspectos sobre a relação com a Organização, depois de ter participado de visita à instituição, selecionado pela própria OCDE. Dentre os aspectos principais do texto, intitulado Brasil resiste a aderir ao "clube dos ricos", o autor salienta a declaração

\footnotetext{
${ }^{111}$ Refere-se ao Conselho composto pelos Ministros de cada Estado-membro.

112 Tradução livre: Resolução do Conselho sobre ampliação e intensificação do engajamento.

113 Tradução livre: Resolução estabelecendo um mecanismo para identificar potenciais candidatos à adesão e os países para intensificação do envolvimento com OCDE (C (2006) 73/FINAL; C / M (2006) 9)) Relatórios: Uma estratégia para a divulgação e ampliação (C (2004) 60) e Intensificação do engajamento: Relatório do Comitê de Relações Exteriores (C (2007) 42).

${ }^{114}$ A reunião de 2007 inseriu-se em um contexto de direcionamento das relações da OCDE, objetivando a aproximação de Brasil, China, Indonésia, Índia e África do Sul; no entanto, como lembra Carlos Márcio Cozendey, Diretor do Departamento Econômico do Itamaraty, a realidade dos países em desenvolvimento demanda, deles, muita cautela diante dos compromissos que uma eventual adesão como membros vai implicar. (COZENDEY, Carlos Márcio. O Brasil e a OCDE: não é de hoje, não é para amanhã. International Centre for Trade and Sustainable Development and Sustainable Development. Pontes, v. 3, n. 4, ago. 2007. Disponível em: <http://ictsd.org/i/news/12438/>. Acesso em: 17 mar. 2011.)
}

${ }^{115}$ ROMERO, Cristiano. Brasil resiste a aderir ao "clube dos ricos". Valor Econômico, 22 jun. 2009, p. A14. 
de um diplomata da Organização que pede o anonimato, na qual reconhece estar a relevância da OCDE dependente da participação de Brasil, China, Índia, Indonésia e África do Sul - isso se mostra coerente com o conteúdo da Resolução C/MIN(2007)4/FINAL. Cristiano Romero destaca, no entanto, a resistência desses países em aderir à Organização.

De fato, a relação entre o Brasil e a OCDE evidencia ter evoluído do interesse brasileiro e sua falta de preparo para o preparo brasileiro e sua falta de interesse ${ }^{116}$. Se em um primeiro momento o governo brasileiro considerava necessário caminhar em direção à OCDE, como a busca de um selo de qualidade, posteriormente o mesmo desenvolvimento brasileiro que o tornou interessante à OCDE fez desaparecer aquela necessidade. Assim que, para o Ministério das Relações Exteriores do segundo mandato do governo Lula, a despeito de algumas iniciativas ainda dedicadas do Ministério da Fazenda em sentido de aproximação, as relações do Brasil com a OCDE deixariam de ser priorizadas.

Importa anotar que as relações com a OCDE foram, de fato, sendo estabelecidas de modo fragmentado, ao longo do tempo, até o Decreto $\mathrm{n}^{\mathrm{o}}$ 17/2005, que pretendeu organizar a atuação brasileira. Vários órgãos do governo brasileiro foram estabelecendo relações sem uma unidade de escopo - pelo menos aparentemente - e, em fevereiro de 2005, o presidente Luís Inácio Lula da Silva editou um decreto sem numeração, em que atribui ao Ministério das Relações Exteriores a centralização das relações com a $\mathrm{OCDE}^{117}$.

\footnotetext{
${ }^{116}$ Em artigo publicado na imprensa, o ex-embaixador Rubens Barbosa propõe que a adesão brasileira seria uma alternativa adequada, tal qual a opção mexicana. (BARBOSA, Rubens. O Brasil e a OCDE. O Estado de S. Paulo, 27 dez. 2005. Disponível em: <www.eagora.org.br/arquivo/O-Brasil-e-a-OCDE〉. Acesso em: 17 mar. 2011.)

117 Disponível em: <http://www.planalto.gov.br/ccivil_03/_Ato2004-2006/2005/Dnn/Dnn10445.htm.>. Acesso em: 31 maio 2011:
}

"Decreto de 17 de fevereiro de 2005

Cria, no âmbito do Ministério das Relações Exteriores, o Grupo Interministerial de Trabalho para os fins que especifica.

O PRESIDENTE DA REPÚBLICA, no uso da atribuição que lhe confere o art. 84, inciso VI, alínea a, da Constituição, DECRETA:

Art. 1ํㅜ Fica criado, no âmbito do Ministério das Relações Exteriores, o Grupo Interministerial de Trabalho para funcionar como núcleo de coordenação e acompanhamento da atuação brasileira junto à Organização para a Cooperação e o Desenvolvimento Econômicos - OCDE.

Art. $2^{\circ} \mathrm{O}$ Grupo terá por objetivo, entre outros:

I - analisar estudos da OCDE;

II - elaborar estudos acerca de temas específicos de interesse para as relações do Brasil com a OCDE;

III - examinar a compatibilidade dos instrumentos da OCDE com a política e a legislação brasileiras;

IV-- coordenar a participação brasileira em órgãos da OCDE; 
A participação brasileira deu-se, assim, com os Comitês da OCDE, de modo fragmentado, mas implicando a assunção de compromissos, inclusive de aportes financeiros, além das despesas normais do engajamento de pessoal. Foram praticados atos diversos, na ordem internacional, conduzidos algumas vezes por órgãos distintos (Ministérios), que acabaram por formar um feixe de relações entre o Brasil e a OCDE.

A rigor do texto constitucional, seria possível considerar que o ingresso do Brasil em atividades da OCDE demandaria, sob uma análise inicial, a manifestação congressual específica, nos termos do artigo 49, inciso I, da Constituição Federal ${ }^{118}$. Isso

V - colaborar na organização de eventos da OCDE no Brasil, bem como em outras iniciativas dela de interesse do País;

VI - fornecer subsídios para a elaboração de políticas afetas ao relacionamento com a OCDE; e

VII - contribuir para a promoção das relações entre o Brasil e a OCDE e para a divulgação de estudos por ela realizados no País.

Parágrafo único. O Grupo Interministerial poderá criar grupos técnicos para a execução das atividades de que tratam os incisos I a VII.

Art. 3ำ O Grupo Interministerial será coordenado pelo Subsecretário-Geral para Assuntos Econômicos e Tecnológicos do Ministério das Relações Exteriores e integrado por um representante de cada órgão a seguir indicado:

I - Casa Civil da Presidência da República;

II - Ministério da Fazenda;

III - Ministério do Desenvolvimento, Indústria e Comércio Exterior;

IV - Ministério da Agricultura, Pecuária e Abastecimento;

V - Ministério da Ciência e Tecnologia; e

VI - Ministério do Planejamento, Orçamento e Gestão.

Parágrafo único. Os membros de que tratam os incisos I a VI, inclusive seus suplentes, serão indicados pelos titulares dos órgãos representados e designados pelo Ministro de Estado das Relações Exteriores.

Art. 4ํㅡㅁ Grupo Interministerial poderá solicitar a participação e cooperação de outros Ministérios e órgãos públicos, bem assim estabelecer formas e canais de colaboração com centros de pesquisa e entidades da sociedade civil que tenham interesse direto nas questões de que trata a OCDE.

Art. $5^{\circ}$ Caberá ao Departamento Econômico do Ministério das Relações Exteriores o exercício da atribuição de secretaria-executiva do Grupo Interministerial.

Art. $6^{0}$ A participação no Grupo Interministerial não será remunerada, mas considerada prestação de serviço público relevante.

Art. $7^{\mathrm{o}} \mathrm{O}$ Ministro de Estado das Relações Exteriores, mediante proposta do Coordenador do colegiado, poderá declarar extinto o Grupo Interministerial criado por este Decreto.

Art. $8^{\circ}$ Este Decreto entra em vigor na data de sua publicação.

Brasília, 17 de fevereiro de 2005; $184^{\circ}$ da Independência e $117^{\circ}$ da República.

\section{LUIZ INÁCIO LULA DA SILVA}

Celso Luiz Nunes Amorim

Este texto não substitui o publicado no D.O.U. de 18.2.2005"

118 “Art. 49. É da competência exclusiva do Congresso Nacional: 
porque as relações estabelecidas no âmbito internacional, que geram ônus, dependeriam desse aval parlamentar - especialmente no tocante a uma Organização Internacional da qual o Brasil não participa por adesão à sua Carta constitutiva.

Com efeito, o ato de aceitação brasileira em participar das atividades de determinado Comitê de Organização Internacional implica direitos e deveres - ainda que se pudesse argumentar, há tanto o ônus do engajamento quanto o ônus financeiro da contribuição contínua -, e sob o rigor literal da regra constitucional não escapariam ao iter procedimental adotado, inclusive, por ocasião do ingresso brasileiro no Comitê do Aço, como será possível observar adiante.

A esse propósito, verifica-se, por exemplo, do documento intitulado "Relatório de Avaliação do Plano Plurianual 2004-2007”, no Caderno 14, relativo ao Ministério das Relações Exteriores, que foram realizadas despesas atinentes a ações perante a OCDE. Sobre isso, o Anexo I traz, sob a ação n⿳ 0 0865, a informação de que de 2004 a 2006 foi prevista, anualmente, uma despesa orçamentária de $\mathrm{R} \$ 128.711,00$, valor que saltou para uma previsão, no ano de 2007, de $\mathrm{R} \$ 457.000,00$. Em cada um desses anos, com exceção de 2004, a execução aproximou-se dos valores previstos.

Já no tocante ao posto de representação mantido, o documento mostra um decréscimo nas previsões, que vão de $\mathrm{R} \$ 3.123 .315,00$, em 2004, a $\mathrm{R} \$ 500.000,00$, em 2007. De igual modo, a execução vai de R \$ 1.763.369,00, em 2004, a nenhum centavo gasto, em 2007.

Também podem ser encontradas menções, na obra do embaixador Denis Fontes de Souza Pinto, a respeito dos compromissos financeiros que o Brasil assumiu perante a Organização, no contexto do estreitamento de laços e da participação em suas atividades.

Aos se partir dessas premissas, seria de se esperar que de alguma maneira houvesse manifestação congressual sobre os atos internacionais onerosos implicados na relação estabelecida com a OCDE; contudo, uma breve pesquisa aponta para certa variação e inconstância de procedimentos envolvendo os atos brasileiros concernentes às relações com a OCDE.

I - resolver definitivamente sobre tratados, acordos ou atos internacionais que acarretem encargos ou compromissos gravosos ao patrimônio nacional; $[\ldots]$ " 
Veja-se, a esse propósito, que, segundo o sítio eletrônico ${ }^{119}$ do Ministério da Fazenda, o Brasil participa das seguintes atividades na $\operatorname{OCDE}^{120}$ :

- como membro pleno: Grupo de Trabalho sobre Diretrizes para Empresas Multinacionais; Centro de Desenvolvimento; Comitê do Aço; Grupo de Trabalho sobre Corrupção; Força Tarefa para Ação Financeira;

- como membro observador: Comitê do Comércio; Comitê de Gestão Pública, a partir do corrente ano; Comitê de Investimento Internacional e Empresas Multinacionais; Comitê de Legislação e Política da Concorrência; Comitê de Agricultura; e do Grupo de Trabalho sobre Transportes Marítimos;

- Fórum sobre Economias de Mercados Emergentes; seminários no âmbito do "Diálogo da OCDE com Economias Dinâmicas de Países Não Membros" e outras reuniões de interesse, realizadas pela Organização.

Sobre o Centro de Desenvolvimento, o embaixador Denis Fontes de Souza Pinto faz o seguinte comentário em nota de rodapé n. 138 de seu livro ${ }^{121}$ :

Os EUA, até 1997, contribuíam anualmente com $25 \%$ do orçamento, em torno de US $\$ 2,4$ milhões do total de cerca de US\$ 10 milhões. O Japão contribui também com 25\%, seguido da Alemanha com 11,89\%, da França com 7,5\%, da Itália, com 5,68\%, do Canadá, com 2,88\%, da Espanha, com 2,86\% e do Brasil, com 2,76\%. (sem grifo no original)

$\mathrm{O}$ autor ainda menciona, na nota de n. 148 da referida obra ${ }^{122}$, que a contribuição brasileira ao Comitê do Aço seria de US\$ 9.000,00 por ano, e ao Comitê de Comércio, no qual é observador, de US\$ 6.000,00 anuais. Por fim, no que tange ao Comitê de Investimentos Internacionais e Empresas Multinacionais, a contribuição, segundo a nota n. $154^{123}$, seria, anualmente, de US\$6.000,00.

Sabe-se, portanto, que a participação nos Comitês implica ônus financeiro ${ }^{124} \mathrm{e}$, em rigor, assunção de compromissos - como é o caso do compromisso de implementação

\footnotetext{
${ }^{119}$ Sítio destinado a tratar do Ponto de Contado Nacional, no contexto das Linhas Diretrizes, o qual, como será possível verificar, está instalado no interior da organização do Ministério da Fazenda (http://www.fazenda.gov.br/sain/pcnmulti/ocde.asp).

${ }^{120}$ Disponível em: <http://www.fazenda.gov.br/sain/pcnmulti/ocde.asp>. Acesso em: 23 abr. 2011.

${ }^{121}$ PINTO, Denis Fontes de Souza. OCDE: uma visão brasileira, p. 107.

${ }^{122}$ Ibid. p. 113.

${ }^{123}$ Ibid. p. 115.

${ }^{124}$ Importa anotar que não é a despesa de participação em si, um elemento de ônus do art. 49, inciso I, da Constituição Federal; mas sim o contexto das contribuições obrigatórias periódicas, para manutenção das atividades da própria organização internacional, conjugado com os demais deveres decorrentes de tal participação, como observância de normas e implantação de decisões em geral, fornecimento de informações entre outros.
} 
da Declaração sobre Investimento Internacional e Empresas Multinacionais, com o dever de instalação do Ponto de Contato Nacional $(\mathrm{PCN})$, que constitui condição para participação do Comitê de Investimentos. É sabido, ainda, que há previsão orçamentária para fazer frente às obrigações do País perante a OCDE - conforme demonstram as informações do Relatório de Avaliação do Plano Plurianual de 2004-2007. Veja-se que a situação não demonstra se afigurar como um problema do ponto de vista administrativofinanceiro, porque não se pode dizer, de antemão e à vista das informações ora apresentadas, que houve realização de despesas sem a devida previsão orçamentária, mas uma questão de organização institucional.

É inegável haver uma questão de suma importância sobre as formalidades constitucionais para a prática de atos internacionais relacionados à participação brasileira em atividades de órgãos da OCDE e, principalmente, sobre uma linha uniforme de atuação a esse respeito. Essa questão fará tanto mais sentido quanto se observe, mais uma vez, uma das notas de rodapé da já mencionada importante obra do embaixador Denis Fontes de Souza Pinto. Trata-se, mais precisamente, da nota $\mathrm{n}$. 132, que lembra ter sido o ingresso do Brasil no Comitê do Aço antecedido de manifestação formal do Congresso Nacional ${ }^{125}$ com a aprovação do Poder Legislativo, a qual se deu pelo Decreto Legislativo $\mathrm{n}^{\mathrm{o}}$ 33/1998 ${ }^{126}$-, nos termos do artigo 49, inciso I, da Constituição Federal:

Em decorrência de parecer, o Brasil só pôde formalizar a participação como membro pleno, após a ratificação pelo Congresso Nacional do acordo por troca de notas, em razão do Brasil não ser membro da OCDE e ter de passar a contribuir financeiramente. Formalmente, o Brasil é membro pleno do Comitê do Aço só a partir de maio de 1998, quando da

\footnotetext{
${ }^{125}$ Destaque-se, por oportuno, não ter havido edição de decreto presidencial, a seguir da aprovação do Congresso Nacional, tratando do assunto.

126 “O Congresso Nacional decreta:

Art. $1^{\mathrm{o}}$ É aprovado o texto do Acordo por Troca de Notas relativo ao ingresso do Brasil, na qualidade de membro pleno, no Comitê do Aço da Organização para a Cooperação e o Desenvolvimento Econômico OCDE, celebrado entre o Governo da República Federativa do Brasil e aquela Organização, em Paris, em 17 de junho de 1996.

Parágrafo único. São sujeitos à aprovação do Congresso Nacional quaisquer atos que possam resultar em revisão do referido Acordo, bem como quaisquer ajustes complementares que, nos termos do art. 49, I, da Constituição Federal, acarretem encargos ou compromissos gravosos ao patrimônio nacional.
}

Art. $2^{\underline{0}}$ Este Decreto Legislativo entra em vigor na data de sua publicação.

SENADO FEDERAL, EM 7 DE ABRIL DE 1998

Senador ANTONIO CARLOS MAGALHÃES

Presidente do Senado Federal" 
comunicação da aprovação pelo Congresso Nacional, apesar de ter, na prática, participado plenamente desde março de 1996. [... $]^{127}$

É verdade que no Comitê do Aço o Brasil ingressou como participante pleno, diferente de sua condição no Comitê de Investimentos, no qual é considerado observador regular. Há, realmente, diferença no nível de comprometimento na relação, mas isso não elide o fato de que a participação no Comitê de Investimentos acarreta ônus ao Brasil como se tem visto com recorrência, notadamente pela obrigação de implantação do PCN.

Mesmo assim, e a despeito das várias frentes de relacionamento entre o Brasil e a OCDE, não se encontrou nenhuma outra manifestação congressual ou assemelhada na pesquisa empreendida, no que diz respeito à participação brasileira em qualquer outro dos Comitês ou Grupos - diferente, aparentemente, da regra adotada por ocasião do ingresso brasileiro no Comitê do Aço, embora a condição do País nesse Comitê seja diversa.

Do ponto de vista prático, o relacionamento entre o Brasil e o Comitê de Investimentos pode ser entendido como uma aproximação própria da atividade rotineira de relações exteriores (mais fundada no artigo 84, VII, da CF, do que no inciso seguinte, VIII), diferente do efetivo ingresso no Comitê do Aço - em que o Brasil ingressou como participante efetivo e não como mero observador. Não se pode negar que há níveis de relacionamento e de comprometimento que devem ser distinguidos. E encarar o relacionamento brasileiro com o Comitê de Investimentos de modo excessivamente formalista teria a desvantagem de condicionar a atividade a uma incerta e talvez demorada espera por uma manifestação parlamentar, obstando de forma pouco razoável - ante a ausência de prejuízos efetivos - o prestígio aos ditames constitucionais de cooperação.

${ }^{127}$ PINTO, Denis Fontes de Souza. OCDE: uma visão brasileira, p. 102. 


\title{
CAPÍTULO 4
}

\section{DECLARAÇÃO SOBRE O INVESTIMENTO INTERNACIONAL E AS EMPRESAS MULTINACIONAIS E O SEU ANEXO COM AS DIRETRIZES DA OCDE PARA AS EMPRESAS MULTINACIONAIS}

\author{
4.1 O Mandato do Comitê de Investimentos: a Declaração sobre o Investimento \\ Internacional e as Empresas Multinacionais e o seu Anexo com as Diretrizes da \\ OCDE para as Empresas Multinacionais
}

O Comitê de Investimentos foi criado em março de 2004, e tem seu mandato atual conferido pela Resolution of the Council on the Terms of Reference of the Investment Committee [C(2008)169 and C/M(2008)20, item 286, ii]. Há termo final previsto para dezembro de 2013, para o mandato em questão, com possibilidade de o Conselho da OCDE prorrogar esse prazo.

A missão do Comitê, nos termos da Resolução que lhe outorga o mandato, é promover o investimento para o crescimento e para o desenvolvimento sustentável no mundo, por meio da cooperação internacional e de reformas políticas. O documento inclui os objetivos de zelar pelos valores relacionados a investimentos, movimentos de capital e serviços e, de modo especial para este trabalho, à promoção da condução responsável dos negócios em uma economia globalizada (promoting responsible business conduct in a globalising economy).

Nesse contexto, está a Declaração sobre o Investimento Internacional e as Empresas Multinacionais (C(76)99/FINAL, de 21 de junho de 1976), composta por quatro partes (dos quatro assuntos de que trata a Declaração): Diretrizes da OCDE para as Empresas Multinacionais, The National Treatment Instrument, International Investiments Incentives and Disincentives e Conflicting Requirements ${ }^{128}$. As Diretrizes da OCDE para as Empresas Multinacionais, por sua vez, acompanham uma Decisão do Conselho, de junho de 2000, que trata da implementação e eficácia das Diretrizes, determinando que os

\footnotetext{
${ }^{128}$ Tradução livre, respectivamente: Instrumento sobre Tratamento Nacional, Incentivos e Desincentivos ao Investimento Internacional e Requisitos de Conflitantes.
} 
países aderentes instalem os PCNs, como instrumentos de fiscalização e controle reproduzindo o sistema de peer pressure.

Ao se considerar, nesse sentido, que a Declaração sobre o Investimento Internacional e as Empresas Multinacionais (Declaração) é um documento pertinente às atividades do Comitê de Investimentos, então compete logicamente ao órgão a fiscalização e a promoção da Declaração e das Diretrizes que ela contém, inclusive no tocante a Estados não membros que a ela tenham se vinculado. A esse propósito, destacam-se as disposições dos itens "a" e "b", do tópico (ii) Method, da Resolução C(2008)169 and $C / M(2008) 20$, item 286, ii:

In order to achieve these objectives, the Committee shall:

a. act as a forum for peer surveillance of policy developments and multilateral dialogue on best practices in the fields of international investment and multinational enterprises, capital movements, and international financial and other services covered by the OECD investment instruments;

b. actively engage with major emerging and other non-Member economies, in particular through non-Members adherence to existing OECD investment instruments, close association in the design of new or revised instruments, policy dialogue and assistance from the Committee; $[\ldots]^{129}$

Ainda que a conclusão não fosse tão acessível, como de fato é, a Decisão do Conselho (C(2000)96/FINAL), emendada pela Decisão do Conselho (C/MIN(2011)11, trata expressamente do papel do Comitê de Investimentos, atribuindo-lhe funções relativas à implementação das Diretrizes e ao funcionamento dos PCNs.

\subsection{A Organização da Declaração e suas Emendas de Revisão (1976-2011)}

A Declaração sobre Investimento Internacional e Empresas Multinacionais é, conforme salientado, um documento de 21 de junho 1976, então já estruturado do modo como é conhecido hoje, abordando as Linhas Diretrizes para as Empresas Multinacionais,

129 Tradução livre: "Para alcançar estes objetivos, a Comissão deve:

a. atuar como um fórum para a vigilância dos pares da evolução da política e do diálogo multilateral sobre as melhores práticas em matéria de investimento internacional e as empresas multinacionais, movimentos de capital e financeiro internacional e outros serviços abrangidos pelos instrumentos de investimento da OCDE;

b. ativamente com as principais economias emergentes e outras economias não membros, em particular pela adesão de não membros a instrumentos de investimento existentes da OCDE, à participação no projeto de novos instrumentos ou revistos, o diálogo de políticas e assistência do Comitê; [...]”. 
Tratamento nacional, Requisitos contraditórios, Incentivos e desincentivos ao investimento internacional e Procedimentos de consulta ${ }^{130}$, além da disposição sobre sua própria revisão periódica. Lembre-se que a menção às Diretrizes, na Declaração, faz remissão ao Anexo I, que contém a descrição pormenorizada dessas Diretrizes, organizada por assuntos, conforme será visto adiante.

As Diretrizes para Empresas Multinacionais, por sua vez, como recomendações para condução de atividades responsáveis no contexto global, também tiveram preservadas as suas linhas originais, sofrendo pequenas atualizações e ajustes que a tornaram mais objetivas e contemporâneas. Para exemplificar, pode-se mencionar a inclusão de referências ao e-commerce e às relações em ambiente de Internet, presentes após a revisão de 2011.

Vale complementar que o texto original da Declaração passou por revisões em 1979, 1984, 1991, 2000 e 2011, mas que nunca chegaram a promover alterações muito drásticas; ao contrário, elas ocorreram em geral em termos de ajustes de redação, inclusão de assuntos que surgiram com o passar do tempo (como o e-commerce) e supressão e restabelecimento de tópicos (como o relativo a Direitos Humanos, conforme apontado adiante).

A aceitação brasileira deu-se nos termos do documento como revisto até 27 de junho de 2000, mas atualmente a redação é determinada segundo a revisão de 25 de maio de $2011^{131}$. Nesse contexto, as Resoluções adotadas pelo Conselho da OCDE em matéria atinente às Diretrizes afetam todos os Estados que tenham se obrigado a implementá-las, aderindo à Declaração que as contém.

A Resolução de maio de 2011, que alterou disposições das Diretrizes, é um exemplo de ato da Organização que gera efeitos para o Brasil; no entanto, conforme será analisado adiante com maior profundidade, dado que as alterações não são de tal magnitude que provoquem especial alteração nos valores propostos pelas Diretrizes e tendo em vista os padrões de conduta não chegam a inovar obrigações legais para as empresas, essa sujeição não demonstra representar verdadeiro problema - e, ainda que representasse, a saída seria simples: a retirada brasileira das atividades do Comitê de Investimentos.

\footnotetext{
${ }^{130}$ Guidelines for Multinational Enterprises, National Treatment, Conflicting Requirements, International Investment Incentives and Disincentives e Consultation Procedures - além do balanço de revisão previsto.

${ }^{131}$ A cronologia e referência dos documentos é a seguinte: 21 June 1976 - C(76)99/FINAL Amendedon13 June 1979 - C(79)102/FINAL; 17 May 1984 - C/M(87)7 Part II(FINAL), Item 111.II c); 4 June 1991 C/M(91)12/FINAL, Item 111.II c); 27 June 2000 - C/M(2000)17; 25 May 2011 - C/MIN(2011)11.
} 


\subsection{As Revisões Periódicas das Linhas Diretrizes perante o Direito Brasileiro}

As Linhas Diretrizes sofrem revisões periódicas. Essa previsão é expressa no seu próprio texto e tem sido observada pelos países-membros. Tanto é assim que em maio de 2011 uma Resolução do Conselho da OCDE aprovou alterações no texto então em vigor desde 2000 - ao qual o Brasil havia aderido.

Há uma assimetria no modelo de alteração das Linhas Diretrizes. As alterações no texto são propostas pelo Comitê de Investimentos, mas aprovadas por um Conselho formado por membros da OCDE. Mas as adesões dos países não membros se referem tão somente ao texto anterior; ademais, como não se trata de países-membros da OCDE, não há base jurídica para supor a sua vinculação ao ato de revisão das Linhas Diretrizes.

No caso de Estado-parte da Convenção da OCDE, o desrespeito às decisões vinculantes do Conselho equivale ao desrespeito ao tratado - nos termos da CVDT; entretanto, dentre os países aderentes à Declaração sobre Investimentos, e meros participantes do Comitê de Investimentos - como é o caso do Brasil - não se pode inferir uma vinculação automática ao novo texto.

Como o texto ao qual o Brasil originalmente aderiu contava com a previsão de revisão - e participando o País do Comitê de Investimentos -, não há o que induza a pensar que o novo texto não possa ser admitido como parâmetro de atuação do $\mathrm{PCN}$, em particular se encarado como um instrumento que reflete uma espécie de consenso, consoante referida anteriormente, e de unidade de desígnios.

Em outras palavras: o Brasil aderiu a um texto, sem ressalvas, que previa a revisão periódica de seus termos. Nesse sentido, admitiu as revisões e, com isso, assumiu o compromisso de se submeter a elas. Entende-se que não há grandes questões a esse respeito, dado que, em primeiro lugar, os ajustes ao texto são, em geral, suficientemente amplos e compatíveis com uma linha de princípios comum aos valores constitucionais brasileiros (o conteúdo das Diretrizes será analisado adiante); em segundo lugar, a não aceitação do Brasil, relacionada a determinada revisão, pode acarretar o seu afastamento do Comitê - compatível com o nível de comprometimento assumido de parte a parte. De fato, este último efeito é uma sanção de natureza jurídica. 


\subsection{O Conteúdo das Linhas Diretrizes da OCDE para as Empresas Multinacionais como Parte da Declaração}

O preâmbulo da Declaração sobre Investimento Internacional e Empresas Multinacionais enuncia dentre suas premissas as necessidades de "fomentar a contribuição positiva que as empresas multinacionais possam trazer ao progresso econômico, social e ambiental, e minimizar e resolver as dificuldades que possam surgir em decorrência das atividades destas empresas”. Daí que, reputando ser benéfica a cooperação internacional mantida em um "quadro de trabalho equilibrado e com instrumentos estreitamente ligados”, os Estados recomendam às empresas em operação em seus ou de seus territórios, a observância das Diretrizes da OCDE para as Empresas Multinacionais:

I. That they jointly recommend to multinational enterprises operating in or from their territories the observance of the Guidelines, set forth in Annex 1 hereto, having regard to the considerations and understandings that are set out in the Preface and are an integral part of them; $[\ldots]^{132}$

O Anexo I a que se refere a Declaração é o próprio texto das Diretrizes da OCDE para as Empresas Multinacionais e contém, atualmente, os Procedimentos de Implementação (integrada pela mais recente Decisão do Conselho da OCDE a respeito das Diretrizes da OCDE para as Empresas Multinacionais, de maio de 2011, conforme será explicado com mais clareza, adiante). O texto desse Anexo I, portanto, é composto por uma mensagem preambular explicativa sobre as Diretrizes, seguido pelo tratamento pontual de onze tópicos, sendo o primeiro sobre Conceitos e Princípios e os outros dez, sobre os seguintes temas: Políticas Gerais, Divulgação, Emprego e Relações Industriais, Direitos Humanos, Meio Ambiente, Combate ao Suborno, Interesses do Consumidor, Ciência e Tecnologia, Concorrência, Fiscalidade e Direitos Humanos ${ }^{133}$. Em continuidade, há o tratamento da implantação do PCN nos diversos países e da atribuição de função ao Comitê de Investimentos - antes referido como Cime -, contendo orientações de procedimento alusivas ao PCN. Importa mencionar, ainda, a previsão de revisão periódica

\footnotetext{
${ }^{132}$ Tradução extraoficial (OCDE): "I. Que recomendam conjuntamente às empresas realizando operações a nível nacional e internacional observarem estas Diretrizes, definidas no Anexo 1 da presente, tendo em conta as considerações e os conhecimentos expostos no Prefácio e que são parte integrante destas.”

${ }^{133}$ Os termos utilizados são da síntese das Diretrizes, publicadas pela OCDE, mas sem caráter de texto oficial; traduzem-se para o texto oficial em inglês como: General Policies, Disclosure, Employment and Industrial Relations, Environment, Combating Bribery, Consumer Interests, Consumer Interests, Science and Technology, Competition e Taxation.
} 
das Diretrizes (Anexo I); de fato essa revisão é sempre aprovada por uma Decisão do Conselho Ministerial. A Decisão Ministerial de maio de 2011, é pertinente adiantar, fez ajustes no texto e restabeleceu o tópico Direitos Humanos aos assuntos tratados nas Diretrizes.

Por fim, importa dizer que o Brasil utiliza uma tradução extraoficial das Diretrizes, produzida pela própria OCDE, mas cuja referência é o texto das Diretrizes conforme a Decisão do Conselho da OCDE de junho de 2000 (anterior à mais recente, portanto).

\subsubsection{O Preâmbulo}

A mensagem preambular apresenta as Diretrizes como recomendações dos aderentes às empresas multinacionais, como princípios de adesão voluntária e padrões de conduta compatíveis com a legislação oficial. São apresentadas, ainda, como uma forma de promoção da harmonia entre as atividades empresariais e as políticas governamentais, de modo a estabelecer um contexto de benefícios mútuos para o Estado, a sociedade e as empresas e os investidores. Há, inclusive, alusão ao investimento sustentável e aos objetivos de preservação do clima para investimentos internacionais.

As Diretrizes e a evolução de seu conteúdo são ainda justificadas com base na observação das particularidades das empresas multinacionais. Segundo o documento, as empresas multinacionais ampliaram a complexidade de suas relações e a relevância para as economias nacionais - inclusive nos países em desenvolvimento; além disso, há destaque para o elo que essas empresas representam entre os países da OCDE e o resto do mundo, evidenciando-se não só a preocupação sobre os benefícios que elas devam gerar aos países receptores, mas também no tocante à proteção ao retorno sobre os investimentos realizados nos países receptores.

Outro valor expressamente presente no texto, além de desenvolvimento sustentável e retorno dos investimentos - englobando aspectos sociais, econômicos e ambientais -, é o contexto de mercado aberto, concorrencial e adequadamente regulado. Veja-se, entretanto, que esses valores são apresentados como elementos intensamente relacionados e simbióticos, com a finalidade última de melhorar o padrão de vida de todos.

As Diretrizes são, conforme salientado, padrões de conduta não obrigatórios, alimentando, nesse sentido, práticas de boa governança corporativa. O documento, ainda 
no preâmbulo, aborda diretamente esse aspecto de sua própria natureza, com uma informação empírica apontando uma vantagem para o crescimento pela aplicação de boas práticas, uma vez que "muitas empresas multinacionais têm demonstrado que o respeito pelos altos padrões de conduta nos negócios pode intensificar o crescimento"134.

De fato, importa lembrar que a OCDE é conhecida como uma importante produtora de conhecimento e pesquisas, de modo que uma afirmação dessa natureza tem um peso bastante relevante. Além disso, o parágrafo complementa-se com a informação de que as pressões competitivas e as elevadas exigências legais podem levar algumas companhias a buscar um diferencial descuidando-se de padrões e princípios adequados, com comprometimento do ambiente concorrencial e consequente deterioração do mercado.

Muitas empresas privadas, como lembra o próprio documento analisado, já adotam correntemente programas internos de instalação e promoção de boas práticas, mas as Diretrizes são apresentadas, nesse contexto, como expectativas compartilhadas, ponto de referência para as empresas e complemento e reforço às iniciativas privadas:

As Diretrizes esclarecem as expectativas compartilhadas sobre a conduta empresarial dos governos aderentes a essas Diretrizes, e fornecem às empresas um ponto de referência. Por conseguinte, as Diretrizes vêm completar e reforçar os esforços privados para definir e implementar uma conduta empresarial responsável ${ }^{135}$.

Ao finalizar essa apresentação prévia das Diretrizes, o texto aponta as relações de identidade das Diretrizes e da atuação da OCDE no campo dos negócios com documentos e organizações internacionais como a Declaração Universal dos Direitos Humanos e a Organização Internacional do Trabalho (OIT).

As Diretrizes elencam, ainda, obrigações governamentais concorrentes à realização dos objetivos pretendidos pelos princípios e padrões designados às empresas. Nesse conjunto citam-se exemplificativamente a importância de políticas macroeconômicas estáveis, tratamento não discriminatório, funcionamento dos tribunais, respeito às leis, entre outros. A compatibilização das leis internas com os padrões das

\footnotetext{
${ }^{134}$ Tradução livre do seguinte original: "many multinational enterprises have demonstrated that respect for high Standards of business conduct can enhance growth."

${ }^{135}$ Tradução extraoficial (OCDE) do seguinte original: "The Guidelines clarify the shared expectations for business conduct of the governments adhering to them and provide a point of reference for enterprises and for other stakeholders. Thus, the Guidelines both complement and reinforce private efforts to define and implement responsible business conduct."
} 
Diretrizes é outro ponto bastante relevante no que toca aos compromissos estatais, a ser examinado adiante.

\subsubsection{Conceitos e Princípios}

O primeiro ponto a merecer destaque é a enunciação de que a observância das Diretrizes não é legalmente exigível (not legally enforceable) - para as empresas, e não no que tange à sua implementação para os Estados. De acordo com o texto, no entanto, seu atendimento deve ser encorajado pelos governos; e não só em relação às empresas multinacionais e às entidades que a possam compor, sejam públicas, privadas ou de capital misto, mas em relação às empresas domésticas também - respeitando-se as particularidades de cada caso. Há, nesse sentido, evidente intento de construção de um ambiente propício às atividades empresariais, com a adesão voluntária das próprias empresas, sob o incentivo dos governos aderentes. Há, assim, contaminação dos princípios gerais que norteiam a própria atuação da OCDE sobre os princípios que pautam as Diretrizes no que há de fundamental: a busca da legitimidade com a adesão voluntária dos envolvidos e o comprometimento individual com os valores coletivos.

Outro ponto de vital importância é o tratamento da cooperação internacional, sob a visão de que as soberanias nacionais - expressas nos limites territoriais - não devem constituir um obstáculo à promoção de direitos, mas um instrumento para sua promoção. Daí que os Estados tenham o compromisso de promover a observância das práticas pelas empresas que operam em seus Estados, em cada território em que essas empresas estiverem atuando:

3. Since the operations of multinational enterprises extend throughout the world, international co-operation in this field should extend to all countries. Governments adhering to the Guidelines encourage the enterprises operating on their territories to observe the Guidelines wherever they operate, while taking into account the particular circumstances of each host country ${ }^{136}$.

\footnotetext{
${ }^{136}$ Tradução extraoficial (OCDE): "Na medida em que as operações realizadas por empresas multinacionais crescem pelo mundo, a cooperação internacional neste campo deverá alcançar todos os países. Os governos aderentes a essas Diretrizes encorajam as empresas realizando operações no seu território a observarem as Diretrizes onde atuarem, tendo sempre em conta as circunstâncias específicas de cada país hóspede.”
} 
Incluem-se, ainda, disposições destinadas à proteção dos interesses das empresas multinacionais, de forma geral. Nesse sentido, há vedação de aplicação das Diretrizes como instrumento de protecionismo e previsão de tratamento equitativo e segundo as normas internacionais, pelos governos locais. Outro aspecto a ser aqui mencionado diz respeito ao compromisso dos governos aderentes de procurar solucionar, de boa-fé, eventuais conflitos legislativos capazes de afetar as empresas multinacionais que devam observar leis de sua sede contrárias às leis de seu local de atuação.

O tópico trata da solução de controvérsias e conflitos, incentivando a adoção de sistemas arbitrais entre empresas e governos - aspecto bastante interessante a considerar-se a assimetria da relação. Saliente-se que o estabelecimento de PCNs e a participação em procedimentos de revisão e consulta também são mencionados como meios de aprimorar a interpretação das Diretrizes.

Por fim, a revisão de 2011 reafirma, no contexto da natureza das Diretrizes, que elas não se prestam a substituir ou se sobrepor à organização interna dos Estados:

2. Obeying domestic laws is the first obligation of enterprises. The Guidelines are not a substitute for nor should they be considered to override domestic law and regulation. While the Guidelines extend beyond the law in many cases, they should not and are not intended to place an enterprise in situations where it faces conflicting requirements. However, in countries where domestic laws and regulations conflict with the principles and standards of the Guidelines, enterprises should seek ways to honour such principles and standards to the fullest extent which does not place them in violation of domestic law ${ }^{137}$.

A esse propósito, as Diretrizes propõem o diálogo e o máximo esforço por observar os seus princípios sem violar a legislação doméstica.

\footnotetext{
${ }^{137}$ Tradução livre: "2. Cumprir as leis nacionais é a primeira obrigação das empresas. As Diretrizes não são um substituto nem devem ser considerados como substitutas do direito interno. Embora as orientações se estendam além da lei em muitos casos, elas não devem e não são destinadas a colocar uma empresa em situações de exigências conflitantes. No entanto, em países onde as leis nacionais e regulamentos conflitem com os princípios e normas das Diretrizes, as empresas devem buscar meios para honrar tais princípios e as normas em toda a sua extensão, de modo a não os colocar em situação de violação do direito interno."
} 


\subsubsection{Políticas Gerais}

Sob o título de políticas gerais são enunciados valores como desenvolvimento sustentável e direitos humanos, além de uma séria de recomendações iniciais. Essas recomendações iniciais partem do convite ao desenvolvimento das capacidades locais e do capital humano, de modo que as empresas multinacionais sejam efetivamente agentes promotores do desenvolvimento local e cheguem às prevenções no tocante à necessidade de se zelar pela efetividade e respeito às Diretrizes.

O documento reitera a importância das boas práticas de governança e da necessidade de se promover as Diretrizes entre outros envolvidos no processo de negócio, e das iniciativas espontâneas de autorregulação, apontando o objetivo de construção de um ambiente de confiança nas relações empresariais e com a sociedade. Nesse contexto, faz colocações direcionadas também ao envolvimento dos trabalhadores com as Diretrizes, com a ressalva de que os empregados não devem ser coagidos, de nenhuma forma, ao apontarem transgressões às Diretrizes. Trata-se de uma previsão natural - embora pudesse mostrar-se óbvia - que, pela redação e contexto, denote reafirmar as Diretrizes mais como um instrumento de colaboração mútua do que como uma arma para conflitos de interesses patrão-empregador:

8. Promote employee awareness of, and compliance with, company policies through appropriate dissemination of these policies, including through training programmes.

9. Refrain from discriminatory or disciplinary action against employees who make bona fide reports to management or, as appropriate, to the competent public authorities, on practices that contravene the law, the Guidelines or the enterprise's policies ${ }^{138}$.

O tópico dedica, complementarmente, dois parágrafos a importantes aspectos das relações com os Estados. O texto, por exemplo, estabelece que as empresas devem recusar benefícios e exceções que possam lhe ser oferecidos, relativos ao cumprimento de normas concernentes a meio ambiente, saúde, segurança, trabalho, impostos, incentivos financeiros, entre outros, e que não sejam compatíveis com a regulamentação oficial.

\footnotetext{
${ }^{138}$ Tradução extraoficial (OCDE): “8. Promover a sensibilização dos trabalhadores quanto à política empresarial mediante a apropriada difusão desta política, recorrendo inclusive a programas de formação profissional.

9. Abster-se de ação discriminatória ou disciplinar contra os empregados que fizerem relatórios sérios à diretoria ou, quando apropriado, às autoridades públicas competentes, sobre as práticas, transgredindo a lei, as Diretrizes ou a política empresarial."
} 
Entende-se que, aparentemente, o objetivo é evitar as relações estabelecidas com base em negociações assimétricas e que possam levar a concessões danosas ao Estado e seus nacionais em troca do estabelecimento de determinada unidade empresarial. $O$ outro parágrafo traz uma disposição simples e direta a respeito da impropriedade de envolvimento nas atividades políticas locais: “Abstain from any improper involvement in local political activities"139.

Faz-se oportuno mencionar, ainda, que o texto é direcionado a condutas que devem ser tanto observadas como encorajadas pelas empresas. Dentre as medidas a serem encorajadas, o texto atual traz menções à cooperação de esforços para promover a liberdade no ambiente da Internet, no tocante à liberdade de expressão e outros direitos civis congêneres: "support, as appropriate to their circumstances, cooperative efforts in the appropriate fora to promote Internet Freedom through respect of freedom of expression, assembly and association online" ${ }^{, 140}$.

\subsubsection{Divulgação}

O objetivo do tópico é promover a transparência das atividades empresariais, criando-se uma série de obrigações relacionadas à alta qualidade na produção das informações e à integridade na respectiva publicação. Há referência à composição do capital social e controle, relatórios ambientais e sociais.

No que concerne à divulgação de informações, é comum um conflito natural entre a necessidade de transparência e a importância de preservação de certas estratégias. Nesse contexto, a parte final do parágrafo primeiro prevê uma razoável ponderação que, sem esvaziar o sentido das orientações acerca da transparência, preserva a confidencialidade: "disclosure policies of enterprises should be tailored to the nature, size and location of the enterprise, with due regard taken of costs, business confidentiality and other competitive concerns"

\footnotetext{
139 Tradução livre: "Abster-se de qualquer envolvimento abusivo nas atividades políticas locais."

${ }^{140}$ Tradução livre: “Apoio, conforme as circunstâncias, aos esforços de cooperação em instâncias adequadas para promover a liberdade da Internet, pelo respeito da liberdade de expressão, reunião e associação on-line."

${ }^{141}$ Tradução extraoficial (OCDE): “As políticas de divulgação das empresas deverão ser adaptadas à natureza, porte e localização da empresa, levando plenamente em conta os custos, a confidencialidade empresarial e outras questões concorrenciais."
} 
Pode-se constatar, mais uma vez, que a aplicação de conceitos de equilíbrio e ponderação é central na correta interpretação das Diretrizes - ou seja, não se trata de meras regras para aplicação por simples silogismo. Mesmo assim, os comandos são bem definidos no que se refere a deveres e incentivos. A esse propósito, por exemplo, o texto apresenta disposições sobre divulgação de riscos da empresa e, segundo o parágrafo quarto, as empresas devem divulgar informações sobre os riscos materiais existentes, mas, no que toca às informações sobre as formas de gerenciar riscos, são apenas incentivadas a apresentá-las.

\subsubsection{Direitos Humanos}

Este tópico foi reinserido pela revisão datada de 25 de maio de 2011 e reafirma a obrigação dos Estados pela proteção dos direitos humanos, e que nesse contexto as empresas devem ter um papel ativo e colaborador acerca dos instrumentos internacionalmente reconhecidos em todos os Estados em que mantenham operações. Dentre os compromissos objetivamente delineados, exemplificam-se:

2. Within the context of their own activities, avoid causing or contributing to adverse human rights impacts and address such impacts when they occur.

3. Seek ways to prevent or mitigate adverse human rights impacts that are directly linked to their business operations, products or services by a business relationship, even if they do not contribute to those impacts ${ }^{142}$.

Pode-se pensar, de antemão, que essas disposições, mesmo singelas, tenham impacto muito efetivo no tocante a empresas multinacionais que desenvolvam atividades produtivas em Estados com reconhecido déficit de observância dos direitos internacionalmente reconhecidos.

\footnotetext{
${ }^{142}$ Tradução livre: "2. No contexto de suas atividades, evite causar ou contribuir para impactos adversos aos direitos humanos e gerencie esses impactos, quando eles ocorrem.

3. Buscar formas de prevenir ou mitigar os impactos adversos de direitos humanos que estão diretamente ligados às operações de seus negócios, produtos ou serviços por uma relação de negócios, mesmo que não tenham contribuído para esses impactos."
} 


\subsubsection{Emprego e Relações Industriais}

Ao tratar do assunto emprego e relações industriais, as diretrizes partem diretamente da afirmação da necessidade de observância das normas locais, acrescentando, a seguir, recomendações compatíveis com padrões internacionais. A esse propósito, a necessidade de respeito às vias de negociações, consultas e diálogo - incluindo sindicatos -, com atenção à transparência nas informações, além da abolição do trabalho infantil, do trabalho forçado e da discriminação entre trabalhadores.

No que tange ao respeito nas relações de trabalho, há menção à preservação da saúde e segurança no trabalho, à promoção do capital humano e investimento na formação da mão de obra, mas há ainda uma disposição que merece destaque, por indicar a adoção de um padrão trabalhista não menos favorável àquele aplicado pelos demais empregadores no mesmo país.

Outro ponto que merece destaque é a disposição concernente à boa-fé nas negociações, com a condenação da prática de ameaça de transferência das operações da empresa para outro país ou medidas do gênero, como forma de pressão.

\subsubsection{Meio Ambiente}

Ao se referir às normas internas e internacionais, e, de modo expresso, ao desenvolvimento sustentável, as Diretrizes tratam da necessidade de se implantar um sistema de gerenciamento ambiental adequado - envolvendo coleta de informações, monitoramento permanente e definição de metas -, além de práticas relacionadas à transparência nesse assunto. Tanto a publicidade de informações e relatórios ambientais como a relação de proximidade com as comunidades envolvidas são, assim, valores defendidos pelas Diretrizes.

O documento aproveita-se, ainda, de princípios internacionais comuns ao direito internacional do meio ambiente, como o do poluidor pagador, da prevenção e da precaução. A respeito deste último, a disposição é especialmente interessante:

4. Consistent with the scientific and technical understanding of the risks, where there are threats of serious damage to the environment, taking also into account human health and safety, not use the lack of full scientific 
certainty as a reason for postponing cost-effective measures to prevent or minimise such damage ${ }^{143}$.

$\mathrm{O}$ incentivo à pesquisa e desenvolvimento, bem como à necessidade de promoção e sensibilização dos consumidores, adotando-se um projeto de aprimoramento ambiental de longo prazo, denota, de forma especial, que as Diretrizes não são meros comandos de abstenção, mas convites muito objetivos de adoção de uma postura ativa, nesse campo. Complementam esse aspecto as disposições sobre formação (educação) dos empregados e contribuição para o desenvolvimento das políticas públicas.

\subsubsection{Combate ao Suborno}

O assunto do combate à corrupção tem um grau de relevância tão grande, que acabou sendo objeto de uma Convenção específica, da própria OCDE - e que contou com a adesão do Brasil ${ }^{144}$. O conceito do que seja corrupção e a sua incompatibilidade com todo sistema moral, ético ou jurídico é de tal ordem forte, que qualquer disposição específica a esse respeito pode soar como uma obviedade. Mesmo assim, a sua enunciação é sempre importante, porque reafirma um valor fundamental para a saúde de qualquer sistema e procura prevenir discursos que, à custa de criatividade, tentem revestir certas práticas de típica corrupção como regulares.

As Diretrizes são diretas e objetivas; atacam inicialmente aspectos gerais do combate ao suborno, pautando o compromisso de "combate" e não meramente de abstenção. Resta evidenciado, também, que o combate se dá pela prevenção, de forma direta e indireta:

Enterprises should not, directly or indirectly, offer, promise, give, or demand a bribe or other undue advantage to obtain or retain business or

\footnotetext{
${ }^{143}$ Tradução extraoficial (OCDE): “4. Quando houver ameaça de sérios prejuízos para o meio ambiente, conforme a avaliação científica e técnica dos riscos, e levando também em consideração a saúde e segurança humanas, não aproveitar a falta de certeza científica para diferir medidas de prevenção ou para minimizar esses prejuízos."

${ }^{144}$ Convenção sobre o Combate da Corrupção de Funcionários Públicos Estrangeiros em Transações Comerciais Internacionais, concluída em Paris, em 17 de dezembro de 1997, promulgada pelo Decreto $\mathrm{n}^{\mathrm{o}}$ 3.678 , de 30 de novembro de 2000.
} 
other improper advantage. Enterprises should also resist the solicitation of bribes and extortion ${ }^{145}$.

Uma lista de compromissos pontuais também é apresentada em complemento, procurando abranger aspectos em geral envolvidos em cenários de corrupção. São mencionadas as relações contratuais com funcionários públicos e seus familiares, que costumam encobrir acertos ilegais, a necessidade de incremento na transparência e divulgação das políticas de gestão, a adoção de mecanismos de controle que inibam a criação de contas paralelas, bem como a necessidade de se assegurar que os seus agentes tenham remuneração apenas para serviços legítimos, entre outros detalhes.

Por fim, importa trazer a lume o último dos parágrafos do tópico:

7. Not make illegal contributions to candidates for public office or to political parties or to other political organisations. Contributions should fully comply with public disclosure requirements and should be reported to senior management ${ }^{146}$.

Embora as Diretrizes procurem bloquear interferências inapropriadas nas políticas locais - conforme parte geral, nos deveres contidos nas General Policies -, percebe-se que as relações transparentes e que observem as normas locais são tidas por legítimas. Desse modo, não há pleno engessamento nas relações que as empresas possam adotar com os poderes públicos e com as forças políticas locais - embora o desenvolvimento dessas relações mereça especial zelo.

\subsubsection{Interesses dos Consumidores}

Os princípios gerais das relações com os consumidores são enunciados como boas práticas empresariais, comerciais e publicitárias, além da adoção de medidas de garantia da segurança e qualidade dos bens e serviços fornecidos. Já no tratamento pontual da matéria, as Diretrizes determinam a garantia de observância das normas legais e

\footnotetext{
${ }^{145}$ Tradução extraoficial (OCDE): “As empresas não deverão, direta ou indiretamente, oferecer, prometer, dar ou pedir suborno ou qualquer outra vantagem indevida para obter ou conservar um negócio ou outra vantagem abusiva. Também deverão resistir à solicitação de suborno ou extorsão."

${ }^{146}$ Tradução extraoficial (OCDE): "Não fazer contribuições ilegais aos candidatos à administração pública ou a partidos políticos ou outras organizações políticas. As contribuições deverão satisfazer plenamente os requisitos de divulgação pública e deverão ser comunicadas aos dirigentes.”
} 
contratuais, especialmente em relação a saúde e segurança, além da preservação da privacidade do consumidor.

Ainda no tocante à conduta específica, as Diretrizes determinam uma relação de informação e transparência, seja quanto aos riscos, conteúdo e tudo o mais que permita a adequada decisão pelo consumidor, seja quanto aos canais de comunicação e reclamações. Ainda nesse contexto, mencione-se a prevenção de práticas desonestas e fraudulentas.

A cooperação com os órgãos governamentais locais novamente é pauta das Diretrizes no que concerne às relações com consumidores, notadamente para prevenção e eliminação de riscos para a saúde e segurança pública relacionados aos seus produtos.

Ressalte-se, por fim, a inclusão de referência ao $e$-commerce, pela revisão feita em 2011: "Take into consideration, in applying the above principles, i) the needs of vulnerable and disadvantaged consumers and ii) the specific challenges that e-commerce may pose for consumers" ${ }^{147}$.

\subsubsection{Ciência e Tecnologia}

O emprego do verbo should ${ }^{148}$, em inglês, denota a força do comando, pelo qual as empresas devem harmonizar suas práticas com as políticas locais de ciência e tecnologia, contribuindo para o desenvolvimento e inovação locais. As empresas são chamadas, ainda, a promover a rápida difusão de tecnologias - resguardados os direitos de propriedade intelectual -, com disposições razoáveis nos termos de licenças e transferências, de modo a promover o desenvolvimento nos países em que estejam instaladas. Ainda nessa linha, as empresas devem realizar trabalhos de desenvolvimento tecnológico nos países em que estiverem instaladas, relacionando-se com as universidades locais, quando for o caso.

\footnotetext{
147 Tradução livre: "Levem em consideração, na aplicação dos princípios acima, i) as necessidades dos consumidores vulneráveis e desfavorecidos e ii) os desafios específicos que o e-commerce pode representar para os consumidores."

${ }^{148}$ Segundo o Concise Oxford American Dictionary: "1 used to indicate obligation, duty, or correctness, typically when criticizing someone's actions [...]" - Tradução livre: "1 usado para indicar obrigação, dever, ou correção, normalmente ao criticar as ações de alguém [...].” (CONCISE Oxford American Dictionary. New York: Oxford University Press, 2006.)
} 


\subsubsection{Concorrência}

Como regra, as Diretrizes reafirmam a necessidade de observância da regulamentação local. Com base nisso, fixa determinados valores, dentre os quais condena a iniciativa ou participação em acordos anticoncorrenciais, caracterizados notadamente pela determinação de preços, manipulação de procedimentos de oferta, restrições ou cotas de produção ou divisão de mercado.

As Diretrizes inserem um conceito importante, lembrando que o impacto no ambiente concorrencial não deve ser relevado unicamente a partir de determinado território, mas além dele também:

Carry out their activities in a manner consistent with all applicable competition laws and regulations, taking into account the competition laws of all jurisdictions in which the activities may have anti-competitive effects $^{149}$.

Uma postura ativa também é cobrada das empresas, que devem cooperar com as autoridades locais e promover o valor do ambiente concorrencial, inclusive entre os seus empregados.

\subsubsection{Fiscalidade}

De modo bastante sintético, o tópico enuncia o princípio da justiça tributária, ao afirmar que as empresas devem contribuir para as finanças públicas dos países hóspedes, segundo as normas locais. É estabelecida, ainda, uma relação direta entre as práticas fiscais e o equilíbrio concorrencial.

\footnotetext{
${ }^{149}$ Tradução extraoficial (OCDE): "Conduzir todas suas atividades de maneira consistente com as leis aplicáveis em matéria de concorrência, levando em conta a aplicabilidade das leis concorrenciais nas jurisdições cujas economias possam ser prejudicadas pelas atividades anticoncorrenciais destas empresas."
} 


\subsection{Natureza Jurídica das Linhas Diretrizes e o "Soft Law"}

A Declaração sobre Investimento Internacional e Empresas Multinacionais é um documento que contém normas enunciativas de compromissos dos Estados aderentes, em primeiro lugar. A Declaração proclama o compromisso dos Estados em seis principais tópicos: Diretrizes da OCDE para as Empresas Multinacionais, tratamento nacional, requisitos contraditórios, incentivos e desincentivos ao investimento internacional, procedimentos de consulta e balanço.

No caso do primeiro tópico, a Declaração tem um caráter vinculatório aos Estados aderentes (na medida em que a inobservância dos compromissos assumidos na Declaração, pelos Estados, acarreta sua retirada do Comitê de Investimentos), para que promovam a observância das Diretrizes pelas empresas multinacionais - como especificação de valores enunciados no preâmbulo da Declaração ${ }^{150}$ e relacionados à ordem interna de cada Estado.

Mesmo as disposições alusivas a tratamento nacional, requisitos contraditórios e balanço contam com construções gramaticais imperativas (deverão, cooperarão e realizarão); ademais, vale lembrar, os membros da OCDE estão obrigados a observar seus termos, e os não membros podem ser expulsos do Comitê se não cumprirem os compromissos decorrentes da adesão à Declaração.

Nesse sentido, o último dos tópicos da Declaração - que contém, ainda, as Diretrizes - refere-se ao Balanço. Sob esse título, há a disposição de que os Estados

[...] realizarão um balanço periódico dos pontos acima citados na intenção de melhorar a eficácia da cooperação econômica internacional entre os governos aderentes, para as questões ligadas ao investimento internacional e às empresas multinacionais.

Essas normas decorrem de uma formação plurilateral ${ }^{151}$ responsável por certa materialidade política diferenciada e que implicam especial legitimidade e eficácia. Note-

\footnotetext{
${ }^{150}$ Releva mencionar que o preâmbulo da Declaração elege como princípios e valores: o investimento nacional como relevante para a economia mundial e para o desenvolvimento; a importância das empresas multinacionais no processo de investimento; a cooperação internacional para o aprimoramento do investimento estrangeiro e da contribuição positiva que as empresas multinacionais possam trazer ao progresso econômico, social e ambiental, entre outros aspectos.

${ }^{151}$ A esse propósito, ver: TRU, Nguyen Huu. Les codes de conduite, un bilan. Revue General de Droit International Public, 1992, p. 48: "Il's agit non d'un acte emanant d'une entité internationale sans puissance pulique mais d'um acte plurilateral résultant des volontés concordantes des Etats avec tout ce que cela represente en termes de pouvoir de contraint politiques et économiques." Tradução livre: "Não se trata de um
} 
se que não se trata de uma autoridade sancionadora a sustentar a norma, mas a colaboração e a aceitação pelos Estados - e até a sua aceitação pelas empresas - marcando uma característica especialmente presente no contexto da governança global, relacionada por Bodansky a uma autoridade de fato, a influenciar as normas internas dos Estados envolvidos ${ }^{152}$.

É verdade que se, por um lado, a Declaração é um documento cuja vinculação é absolutamente voluntária, pelos Estados, e que congrega enunciados decorrentes de forte consenso mesmo entre os entes privados, por outro, sua implementação é acompanhada de um mecanismo de fiscalização e pressão. Trata-se do PCN, a ser examinado em detalhes adiante, mas cuja instalação decorre de um compromisso considerado obrigatório para os Estados participantes do Comitê de Investimentos da OCDE.

Faz-se oportuno adiantar, a esse respeito, que a adesão à Declaração é uma condição para o ingresso no Comitê de Investimentos, e que os Estados participantes desse Comitê se sujeitam às decisões do Conselho. O Conselho da OCDE, por sua vez, decidiu determinar aos países aderentes a "criação" do PCN, para observar o cumprimento das Diretrizes pelas empresas atuantes em seu território e para facilitar a consulta entre os Estados aderentes. Os PCNs visam, portanto, à efetividade das Diretrizes, conforme análise mais detalhada, adiante.

A esse propósito o Conselho da OCDE, que adota atos de natureza vinculante, decidiu pela necessidade de criação dos PCNs. Essa decisão incrementa a força das disposições, dado que os Estados aderentes passam a ter compromissos mais efetivos e práticos (menos vagos), e as empresas passam a ser efetivamente cobradas.

Há, portanto, o seguinte desenho: a Declaração proclama valores e compromissos dos Estados, inclusive o de promover as Diretrizes, as quais são detalhadas em um anexo. As Diretrizes, por sua vez, enunciam padrões de conduta a serem observados pelas empresas multinacionais, sob pena de, como será possível ver adiante, serem submetidas a um procedimento de apuração e divulgação das condutas.

ato emanado de uma entidade internacional sem autoridade pública, mas de um ato plurilateral resultante de vontades concordantes dos Estados com tudo aquilo que isso representa em termos de poder de coação política e econômica."

${ }^{152}$ BODANSKY, Daniel. The legitimacy of international governance: a coming challenge for international environmental law? The American Journal of International Law, v. 93, n. 3, p. 596-624, Jul. 1999, p. 597.

Nesse texto, o autor trata de governança corporativa e meio ambiente e sugere que "has raised questions about the de facto authority of the WTO to override domestic environmental and health laws." É essa autoridade de fato, observada por ele, que se entende, neste estudo, manifestar-se também no caso sob análise. 
Seja como for, importa, neste momento, retomar que as Diretrizes da $O C D E$ para as Empresas Multinacionais se inserem no contexto internacional, mas não são como as demais normas em geral. Isso porque, elas estão afetas à esfera público-privada, envolvendo atores diversos; não possuem elemento sancionador oficial, utilizando-se de mecanismos inovadores de aplicação e de efetividade; expressam valores consensualmente admitidos, num sistema auto-organizado; e até sua internalização, no caso brasileiro, possui particularidades. Há, nesse sentido, uma patente integração entre atores interessados em fortalecer uma sociedade civil global, sob a aplicação de conceitos modernos em direito internacional, com ênfase na promoção de mudanças, muito mais do que em manter a estabilidade do sistema.

Nesses termos, a eficácia das normas da OCDE constitui um fenômeno de notável interesse ao lado da legitimidade, já que são esses os aspectos aglutinadores das demais características, e se relacionam íntima e logicamente entre si, como dizia Weber, lembrado por Bodansky: "As Weber emphasized, the more an institution is perceived as legitimate, the more stable and effective it is likely to be" ${ }^{, 153}$.

Mas a questão que se pretende responder é: esse tipo de normatização, típica de códigos de conduta, configura soft law ${ }^{154}$ ? A pergunta justifica-se à vista da opinião de importantes autores.

Em determinadas matérias, especialmente naquelas que envolvam economia, pode haver resistência na criação de obrigações de forma aberta e individualizada. Nesse sentido, as normas internacionais, paralelamente ao debate dos naturalistas e voluntaristas, desenvolveu uma categoria denominada soft law. A soft law é um tipo de norma consensualmente admitida pelos sujeitos de direito internacional, como padrão necessário de comportamento, ou, como trata Antonio Cassese:

They lay down standards of action that States, international organizations, corporations, and individuals should pursue. Although they are not binding (except when they codify or crystallize general

\footnotetext{
${ }^{153}$ BODANSKY, Daniel. The legitimacy of international governance: a coming challenge for international environmental law? The American Journal of International Law, v. 93, n. 3, p. 603. Tradução livre: "Como Weber enfatizava, quanto mais uma instituição é considerada legítima, mais estável e efetiva ela tende a ser."

${ }^{154}$ NASSER, Salem H. Fontes e normas do direito internacional: um estudo sobre a Soft Law. 2. ed. São Paulo: Atlas, 2006, p. 135: "Ainda no que diz respeito aos comportamentos recomendados que têm por destinatários os Estados ou outros atores, é necessário fazer menção aos códigos de conduta. Mais uma vez, deve-se notar que um tal código pode ser obrigatório se assim decidirem seus autores. O mais comum é, no entanto, que se trate de instrumentos não obrigatórios e, portanto, de natureza recomendatória”.
} 
principles or rules), they evince the consensus of the international community on the path to be taken to tackle environmental issues ${ }^{155}$.

É importante lembrar que, embora a questão da soft law tenha especial relevo em matéria de Direito Internacional do Meio Ambiente, é igualmente destacada em questões econômicas:

O Direito econômico internacional constitui um terreno privilegiado do que se propôs qualificar como "direito suave" (soft law os Anglosaxônicos). As obrigações estão enunciadas de forma frequentemente vaga, e mais sob a forma de compromissos de comportamento do que de resultado ${ }^{156}$.

A caracterização da soft law relaciona-se, assim, à normatividade relativizada ${ }^{157}$ que, segundo Salem Nasser, diz respeito "à sua flexibilidade, sua imprecisão, sua força" $" 158$.

Entende-se, neste estudo, que essa não demonstra ser a real característica da Declaração e das Diretrizes, no que se refere tanto aos Estados quanto às empresas. É que os comandos são todos bastante precisos, determinados, e seu desrespeito acarreta sanção tanto aos membros da OCDE, nos termos de suas normas internas, quanto aos não membros (que podem ser excluídos do respectivo Comitê), como, ainda, das empresas (que se sujeitam ao procedimento dos PCNs e à divulgação de suas condutas - tidas como desfavoráveis à imagem).

155 CASSESE, Antonio. International law. 2th ed. New York: Oxford University Press, 2005. p. 491. Tradução livre: "Eles estabelecem padrões de ação que os Estados, as organizações internacionais, as empresas e os indivíduos devem observar. Apesar de não serem vinculativos (exceto quando codificam ou cristalizam princípios gerais ou regras), evidenciam o consenso da comunidade internacional sobre o caminho a ser seguido para resolver questões ambientais."

${ }^{156}$ QUOC DINH, Nguyen; DAILLIER, Patrick; PELLET, Alain. Direito internacional público, p. 1.074.

${ }^{157}$ NASSER, Salem H. Fontes e normas do direito internacional: um estudo sobre a Soft Law, p. 96.

${ }^{158} \mathrm{O}$ autor pondera que, a partir do conceito proposto pelos idealizadores da Legalization, seria de se relevar os elementos da precisão e da delegação. Além disso, apesar de respeitar debates e nuanças a respeito, reconhece a juridicidade do soft law: "Para Weil, e nisto concordamos, não se pode falar em normatividade relativa que signifique a possibilidade da existência de um 'mais direito' e de um 'menos direito'. Aceitamos, com ele, a idéia da unicidade do fenômeno jurídico dentro de um ordenamento dado, ainda que complexo. É nesse sentido que se fala em limiar normativo (seiul de normativité), pois o direito precisa ser identificável como tal. Quando, no entanto, se tem a normatividade relativa como algo inerente ao direito internacional, está se falando, na verdade, da relatividade da força constringente das normas desse direito, de seu alcance variável, do maior ou menor grau de certeza quanto a obrigações e direitos dela decorrentes, da existência e dos tipos de consequências previstas para o caso de descumprimento das mesmas. Não se está falando, portanto, do problema da validade dessas normas, entendida esta como o seu pertencimento ao ordenamento jurídico." (Ibid., p. 95.) 
Complemente-se que, como bem ressalta Salem Nasser ${ }^{159}$ :

A Declaração se apresenta, nos seus próprios termos, como uma declaração dos Estados membros. Tecnicamente, não é, portanto, uma decisão da organização. Isso ilustra a dificuldade de diferenciar os atos adotados pelos Estados enquanto membros da instituição daqueles que, apesar de negociados no seio daquelas, são atribuíveis à vontade concertada dos Estados na qualidade de entes soberanos e independentes.

Conclui-se, em face dos comandos e das consequências previstas para as normas expressas na sistemática envolvendo a Declaração, que não demonstra ser compatível a sua classificação como soft law.

${ }^{159}$ NASSER, Salem H. Fontes e normas do direito internacional: um estudo sobre a Soft Law, p. 136. 


\section{CAPÍtULO 5}

\section{O PONTO DE CONTATO NACIONAL (PCN)}

\subsection{O Processo de Vinculação Brasileira à Declaração sobre o Investimento Internacional e as Empresas Multinacionais e as Diretrizes da OCDE para as Empresas Multinacionais no Brasil}

A participação brasileira no Comitê de Investimentos demandava um processo de afinamento com os objetivos desse Comitê da OCDE. Como se viu, a participação de Estados não membros é permeada de rigores e condições que não poderiam dispensar o engajamento do Estado participante com os objetivos do Comitê em que pretende ingresso, o que justifica a necessidade de adesão brasileira à Declaração, no contexto de referida participação.

Esse contexto da adesão brasileira à Declaração sobre o Investimento Internacional e as Empresas Multinacionais, contudo, não está inserido em uma política uniforme de engajamento, tampouco foi conduzida segundo as formalidades que evidenciavam ser mais adequadas. É que as relações com a Organização foram sendo conduzidas pelos ministérios afetos às áreas de convergência, passando por fases de maior ou menor interesse de parte a parte.

De fato, conforme observado anteriormente, o relacionamento com a OCDE se construiu dessa maneira, até que em 2005 o então presidente, Luís Inácio Lula da Silva, editou um Decreto sem numeração que centralizava no Ministério das Relações Exteriores a coordenação dessas diversas áreas. A medida foi bastante adequada, pautando-se no conceito da coordenação, e não do comando ou monopólio, já que essas atividades da Organização têm características muito técnicas - mais do que políticas - que demandam um envolvimento direto de secretarias, departamentos e ministérios tecnicamente especializados.

Entende-se que, embora esse relacionamento técnico seja o elemento fundamental perante a OCDE, a participação do Ministério das Relações Exteriores como coordenador geral e, sobretudo, como organizador e patrono das formalidades mostra-se fundamental. É que a solução utilizada para o caso da adesão e implementação das Diretrizes para Empresas Multinacionais no Brasil destoa da prática adotada em linhas 
gerais e não encontra direta correspondência normativa. Em outras palavras, houve inovação no tocante aos cuidados com a forma e a uniformidade institucional que merecem estudo detido.

Importa lembrar, nesse sentido, que o a aproximação do Brasil com o Comitê de Investimentos se deu capitaneado pelo Ministério da Fazenda - direto interessado nos resultados que essa relação poderia gerar. Foi por intermédio do Ministério, também, que o Brasil manifestou sua aceitação à Declaração - com valor de adesão, do ponto de vista da OCDE. Essa aceitação, todavia, não foi objeto de nenhum procedimento formal, de âmbito administrativo ou legislativo, no Brasil. Anote-se, ademais, que essa omissão no procedimento não encontra justificativa em nenhuma norma expressa brasileira - seja relacionada à pratica de um ato internacional, seja no que diz respeito à integração das normas decorrentes da Declaração ao direito interno.

O Ministério da Fazenda, por sua vez, menciona, em material informativo, uma justificativa para prescindir de trâmites mais complexos e manifestação congressual. Essa justificativa era de que a Declaração e seus instrumentos, dentre os quais as Diretrizes, seriam meros atos da OCDE - atos da organização, portanto - e que não integrariam o ordenamento jurídico brasileiro. Isso explica ter prescindido da aprovação congressual, havendo apenas, a seu respeito, a Portaria n⿳⺈ 92/2003 (ato administrativo) de criação do PCN:

Com relação à Declaração sobre Investimento Internacional e Empresas
Multinacionais, o Brasil trocou correspondências com a OCDE,
manifestando a intenção de adotar aquele e outros instrumentos correlatos
da Organização. Anexas à Declaração estão as Diretrizes para as
Empresas Multinacionais, de caráter voluntário, cuja nova versão foi
aprovada pelo Governo Brasileiro em junho de 2000. A Consultoria
Jurídica concluiu, em julho corrente, que a Declaração e os demais
instrumentos acima mencionados podem prescindir da aprovação do
Congresso Nacional, por serem atos da OCDE que não integrarão o
ordenamento jurídico brasileiro. Estão sendo realizados contatos, no
momento, com entidades governamentais e não-governamentais, com
vistas à implementação do chamado "Ponto de Contato Nacional" -
mecanismo de coordenação previsto nas Diretrizes ${ }^{160 .}$

Veja-se, a esse propósito, que a Declaração até poderia ser considerada um ato não vinculativo, em um primeiro momento, e que não geraria, por si, ônus a demandar a manifestação congressual, nos termos do artigo 49 da Constituição Federal. Ocorre que há

${ }^{160}$ Disponível em: <http://www.fazenda.gov.br/sain/pcnmulti/ocde_defini.htm\#adesao>. Acesso em: 28 out. 2008. 
uma regulamentação própria da OCDE, tanto no tocante aos rigores de observância das regras aceitas pelos observadores quanto no que se refere à vinculação à Decisão do Conselho da OCDE que determina, de modo obrigatório (em certa medida), a instalação do PCN - que são mecanismos de controle da aplicação das Diretrizes.

Verifica-se, portanto, que a justificativa apresentada pelo Ministério da Fazenda não encontra amparo técnico - tanto pelo fato de que a Declaração, em si, não é estritamente um ato da OCDE (embora se relacione a atos da OCDE), quanto pelo fato de que a adesão gera compromissos onerosos ao Brasil (dentre os quais a implantação do PCN). Além disso, outras variáveis são igualmente relevantes, como o fato de que as Diretrizes geram compromissos e ônus às próprias empresas multinacionais - particulares -, sujeitando-as a uma espécie de atuação oficial (do Estado) para sua promoção e fiscalização, por meio do PCN, sem qualquer suporte legislativo.

Trata-se, contudo, não de se considerar que o sistema seja incompatível com a ordem jurídica brasileira, nem que os procedimentos adotados tornem o conteúdo da Declaração um corpo estranho e ilegítimo. Faz-se mister, sim, perceber que há relações que encontram sua legitimidade em elementos de consenso, de cooperação, muito embora o sistema jurídico brasileiro pudesse fornecer um ferramental mais explícito para que se pudesse lidar com essas demandas cooperativas.

\subsection{Mecanismo de Controle: o Ponto de Contato Nacional}

A Declaração sobre o Investimento Internacional e as Empresas Multinacionais, conforme disposto em detalhes nas Linhas Diretrizes da OCDE para as Empresas Multinacionais, referia-se à implementação das Diretrizes do ponto de vista prático - conforme os princípios de funcionamento da própria OCDE. Na redação original, de 1976:

11. Governments adhering to the Guidelines will implement them and encourage their use. They will establish National Contact Points that promote the Guidelines and act as a forum for discussion of all matters relating to the Guidelines. The adhering Governments will also participate in appropriate review and consultation procedures to address issues concerning interpretation of the Guidelines in a changing world ${ }^{161}$.

\footnotetext{
${ }^{161}$ Tradução livre: “11. Os signatários das Diretrizes deverão implementá-las e incentivar o seu uso. Eles vão
} estabelecer Pontos de Contato Nacionais que promovam as Diretrizes e atuarão como um fórum para a 
O documento fazia alusão ao estabelecimento do Ponto de Contato Nacional $(\mathrm{PCN})$.

Como já explanado, as Diretrizes são objeto de revisões periódicas, tendo o Brasil manifestado aceitação à versão emendada em junho de 2000. Nesse documento o assunto Ponto de Contato Nacional recebeu especial atenção, ganhando um texto específico, distinto daquele da enunciação das Linhas Diretrizes. Assim, sob o título Procedimentos de Implementação, a decisão do Conselho da OCDE, de junho de 2000, dispôs:

1. Adhering countries shall set up National Contact Points to further the effectiveness of the Guidelines by undertaking promotional activities, handling enquiries and contributing to the resolution of issues that arise relating to the implementation of the Guidelines in specific instances, taking account of the attached procedural guidance. The business community, worker organisations, other non-governmental organisations and other interested parties shall be informed of the availability of such facilities ${ }^{162}$.

Sobre o Comitê de Investimentos, ficou decidido que deveria promover diálogos periódicos sobre as Diretrizes e sobre os Pontos de Contato Nacionais, havendo a possibilidade de convite ao Comitê Consultivo da OCDE para as Empresas e Indústria (Biac) e ao Comitê Consultivo Sindical (Tuac), além de outras organizações e de países não membros ${ }^{163}$. Cabe ao Comitê ser o órgão de processamento das informações atinentes à implementação das Diretrizes, para emissão de relatórios ao Conselho da OCDE.

Mencione-se, ainda, a previsão de que o Comitê de Investimentos passaria a ser o ente responsável pelos esclarecimentos apresentados a respeito das Diretrizes.

discussão de todos os assuntos relacionados com as Diretrizes. Os signatários também participarão de procedimentos adequados de revisão e consulta para tratar de questões relativas à interpretação das Diretrizes em um mundo em mudança."

${ }^{162}$ Conforme tradução extraoficial da própria OCDE: “1. Os países aderentes criarão Pontos de Contato Nacionais para levar a efeito atividades promocionais, responder a pedidos de informação, participar em discussões com as partes envolvidas sobre todas as matérias abrangidas pelas Linhas Diretrizes, de modo a contribuírem para a resolução de problemas que possam surgir neste âmbito, tendo em devida conta as orientações de procedimento adiante anexadas. A comunidade empresarial, as organizações sindicais e as outras partes interessadas serão informadas sobre a disponibilidade das atividades desenvolvidas."

${ }^{163}$ O texto emendado em 2011 mantém essas disposições, nos seguintes termos: "The Committee shall periodically invite the Business and Industry Advisory Committee to the OECD (BIAC), and the Trade Union Advisory Committee to the OECD (TUAC) (the 'advisory bodies'), OECD Watch, as well as other international partners to express their views on matters covered by the Guidelines. In addition, exchanges of views with them on these matters may be held at their request." 
No tocante aos PCNs, a decisão determina a sua criação, pelos países aderentes, como mecanismo de promoção, solução de questão, desenvolvimento de atividades e partilha de experiência com outros $\mathrm{PCNs}^{164}$.

Em maio de 2011, o assunto foi objeto de nova revisão, aprovada por decisão do Conselho da OCDE, que em seu texto reiterou o compromisso de instalação do PCN pelos países aderentes, individualmente, como mecanismo central de promoção das Diretrizes sob várias formas de ação, dentre as quais, receber denúncias de violações, por empresas multinacionais, de princípios e valores definidos nas Diretrizes.

É salutar reiterar que o Ponto de Contato Nacional (PCN) é um mecanismo montado em cada país aderente, formando uma rede, que tem por função promover os valores reputados fundamentais pela OCDE e descritos nas Diretrizes.

Após a Decisão do Conselho da OCDE de junho de 2000, as Diretrizes vêm acompanhadas por um documento denominado Guia de Procedimentos (Procedural Guidance), que trata pormenorizadamente da atuação dos PCNs. Segundo esse documento, a função do PCN é promover a eficácia das Diretrizes, atuando segundo critérios de visibilidade, acessibilidade, transparência e responsabilidade.

As orientações de procedimento do PCN contêm instruções organizadas em quatro tópicos: Modalidades institucionais, Informação e Promoção, Implementação em Circunstâncias Específicas e Elaboração de Relatórios ${ }^{165}$. Ao final do Guia de Procedimentos, há ainda um tópico tratando da atuação específica do Comitê de Investimentos (antigo Cime), ao qual caberá prestar assistência aos PCNs, especialmente no que tange à interpretação das Diretrizes, e análise dos relatórios, além do controle da atuação do PCN em cada país.

\footnotetext{
${ }^{164} \mathrm{O}$ documento dispõe: "1. Adhering countries shall set up National Contact Points for undertaking promotional activities, handling inquiries and for discussions with the parties concerned on all matters covered by the Guidelines so that they can contribute to the solution of problems which may arise in this connection, taking due account of the attached Procedural Guidance. The business community, employee organisations, and other interested parties shall be informed of the availability of such facilities.

2. National Contact Points in different countries shall co-operate if such need arises, on any matter covered by the Guidelines relevant to their activities. As a general procedure, discussions at the national level should be initiated before contacts with other National Contact Points are undertaken.

3. National Contact Points shall meet annually to share experiences and report to the Committee on International Investment and Multinational Enterprises."

165 Tradução livre do seguinte original: "Institutional Arrangements, Information and Promotion, Implementation in Specific Instances e Reporting."
} 
A respeito desses tópicos sobre o $\mathrm{PCN}$, nos termos da Decisão $\mathrm{C} / \mathrm{MIN}$ (2011)11, que aprovou a última das revisões das Linhas Diretrizes ${ }^{166}$, devem-se relevar: as modalidades institucionais, a informação e promoção, a implementação em circunstâncias específicas, a elaboração de relatórios.

\subsubsection{Modalidades Institucionais ${ }^{167}$}

O arranjo institucional do PCN é de livre deliberação pelo Estado comprometido com sua instalação. Isso significa, na prática, que pode ser montado dentro da estrutura oficial, ou mesmo com a participação de outras organizações e da sociedade civil. Isso explica que, como exemplificado pelo próprio documento, o PCN possa ser um funcionário do governo, ou um serviço comandado por um funcionário do governo, ou mesmo ser estruturado como um órgão colegiado.

Como se trata de um mecanismo adotado para tratar da efetividade das Diretrizes para Empresas Multinacionais, demanda que estabeleça relações próximas e de diálogo constante com os atores diretamente envolvidos, como os sindicatos, as organizações e associações empresariais e de trabalhadores, entre outros.

O Relatório Anual de 2010 traz alguns exemplos de conformação dos PCNs no período 2009-2010. Relata a existência de vinte PCNs compostos por departamentos governamentais singulares, oito de departamentos governamentais múltiplos, dois PCNs compostos pelo governo e por representantes das empresas, nove compostos por governo, empresas e sindicatos, um composto por governo, empresas, sindicatos e organizações não governamentais - e, ainda, dois PCNs mistos, compostos por especialistas independentes e representantes dos governos ${ }^{168}$.

\footnotetext{
${ }^{166}$ Documento denominado OECD Guidelines For Multinational Enterprises: update 2011.

${ }^{167}$ Tradução livre de Institutional Arrangements.

${ }^{168}$ L1. Report by the Chair of the 2010 Annual Meeting of NCPS, p. 14.
} 


\subsubsection{Informação e Promoção ${ }^{169}$}

Cabe aos PCNs a ampla divulgação das Diretrizes, inclusive nos idiomas locais. De fato, é oportuno reiterar a existência tanto de um documento oficial, nos idiomas francês e inglês, como também da síntese em idioma português ${ }^{170}$, que, embora considerada uma tradução extraoficial do documento, é um exemplo de meio de divulgação utilizado pelo PCN.

Outro aspecto é o relacionamento que se espera seja desenvolvido pelo PCN, de modo a manter diálogo próximo e constante com a sociedade civil, com outros PCNs e mesmo com governos de países não aderentes. É do PCN a responsabilidade por atender pedidos de informações desses atores.

\subsubsection{Implementação em Circunstâncias Específicas ${ }^{171}$}

O Guia de Procedimentos dedica o assunto tratado neste tópico às medidas que devem ser adotadas pelo PCN a fim de implementar as Diretrizes, garantindo sua efetividade. Refere-se a uma instância específica que, por sua vez, é o mecanismo definido para que os PCNs atuem na solução de controvérsias e questões que possam surgir da aplicação concreta e efetiva das Diretrizes. Essa instância se baseia fundamentalmente na negociação e composição das partes, com previsão de relatórios sobre o desenlace dos casos que cheguem a essa instância.

\subsubsection{Elaboração de Relatórios ${ }^{172}$}

Cabe ao PCN relatar anualmente toda a atividade desenvolvida ao Comitê de Investimentos. De acordo com o Guia de Procedimentos, o relatório deve conter

\footnotetext{
169 Tradução livre de Information and Promotion.

${ }^{170}$ Elaborada pela própria OCDE e disponível no sítio eletrônico do PCN brasileiro, de responsabilidade do Ministério da Fazenda (http://www.fazenda.gov.br/sain/pcnmulti/ocde.asp).

${ }^{171}$ Tradução livre de Implementation in specific instances.

${ }^{172}$ Reporting.
} 
informações sobre a natureza e os resultados das atividades do PCN, especialmente as atividades de implementação em instâncias específicas.

De fato, há uma série de obrigações do PCN no tocante à emissão de relatórios sobre as instâncias específicas, que se prestam a alimentar o sistema com informações sobre o seu desenvolvimento e efetividade, mas cujo efeito é de mecanismo de pressão sobre as empresas.

\subsection{Empresas Multinacionais: a Sujeição às Linhas Diretrizes}

A compreensão do alcance da expressão empresas multinacionais é relevante na medida em que define os destinatários das Linhas Diretrizes. De fato, a definição de empresa multinacional é tema já bastante debatido na doutrina internacionalista, sendo referência, aqui, o exemplo do trabalho de Cláudia Perrone-Moisés ${ }^{173}$.

Ao reconhecer a inexistência de uma categoria específica de enquadramento, a autora sugere uma análise econômica prévia. Nesse sentido, menciona Charles Leben, R. Vernon, Ghertman e Michalet ${ }^{174}$, desenvolvendo ideias pautadas na análise de três critérios de definição econômica: o quantitativo, o de gestão e o de abordagem prospectiva da empresa. O primeiro atém-se, por exemplo, a número de filiais ou faturamento, o segundo envolve critérios de subordinação ao passo que o terceiro reúne uma série de características ideais. Após problematizar suficientemente a questão, Cláudia Perrone-Moisés coloca em pauta a opinião de Celso Lafer, para quem a maioria dos conceitos tradicionais relacionados à pessoa jurídica é de "modelos jurídicos que não abarcam o conceito econômico da empresa multinacional" ${ }^{, 75}$, concluindo:

\footnotetext{
${ }^{173}$ PERRONE-MOISÉS, Cláudia. O código de conduta da ONU para as empresas multinacionais instrumento jurídico de regulamentação das relações econômicas internacionais. 1991. Dissertação (Mestrado) - Departamento de Direito Internacional da Faculdade de Direito da Universidade de São Paulo FDUSP, São Paulo, 1991.

${ }^{174}$ LEBEN, Charles. Problème de définition juridique. In: GOLDMAN, Berthold (Org.). L'Entreprise Multinationale face au droit. Paris: LItec, 1977, p. 44-73; VERNON, Raymond. Les Entreprises Multinationales. Paris: Calman-Lévy, 1973, p. 20; GERTHMAN, Michel. Les multinationales. Paris: PUF, 1985, p. 4; MICHALET, Charles-Albert. Le capitalisme mondial. Paris: PUF, 1985, p. 11, todos mencionados por PERRONE-MOISÉS, Cláudia. Op. cit., p. 25.

${ }^{175}$ LAFER, Celso. Comércio e relações internacionais. São Paulo: Perspectiva, 1977, p. 26. In: PERRONEMOISÉS, Cláudia. Op. cit., p. 36.
} 
[...] entendemos que o conceito de empresa multinacional deve ser tratado com certa flexibilidade, tendo em vista as manifestações e funções dessas empresas no sistema econômico internacional, sem tentar enquadrar o fenômeno dentro de determinada categoria estrutural-formal uma vez que, dificilmente será suficiente para abarcar todas as facetas que o mesmo pode apresentar.

Com esteio em uma perspectiva evidentemente prática, o professor Peter $\mathrm{T}$. Muchlinski ${ }^{176}$ lembra que os membros da OCDE - que classifica como o mais homogêneo grupo de Estados - acordaram uma definição, já na primeira versão das Linhas Diretrizes, em 1976. O Professor faz aqui referência ao item “4”, dos Conceitos e Princípios (I), que ainda permanece, na versão 2011 (item “3”, 2000), com a seguinte redação:

[...] They usually comprise companies or other entities established in more than one country and so linked that they may co- ordinate their operations in various ways. While one or more of these entities may be able to exercise a significant influence over the activities of others, their degree of autonomy within the enterprise may vary widely from one multinational enterprise to another. Ownership may be private, State or mixed. The Guidelines are addressed to all the entities within the multinational enterprise (parent companies and/or local entities). According to the actual distribution of responsibilities among them, the different entities are expected to co-operate and to assist one another to facilitate observance of the Guidelines ${ }^{177}$.

Ressalve-se que a disposição mencionada é precedida de uma relevante observação. As Linhas Diretrizes, antes de apresentarem essa sintética, prática e útil noção de empresas multinacionais - de inegável ânimo econômico - previne que "não é necessário definir precisamente as empresas multinacionais para os objetivos destas Linhas

\footnotetext{
${ }^{176}$ MUCHLINSKI, Peter T. Multinational enterprises and the law. 2th ed. New York: Oxford University Press, 2007, p. 6: "the politically and economically more homogeneous group of states belonging to the OECD arrived, in 1976, at an agreed definition of the MNE, for the purposes of the OECD Guidelines on Multinational Enterprises. [...] The crucial characteristic of a MNE is, according to this definition, the ability to coordinate activities between enterprises in more than one country. Other factors are not decisive. [...]". Tradução livre: "o grupo política e economicamente mais homogêneo, de Estados pertencentes à OCDE, chegou, em 1976, a uma definição consensual do MNE, para efeitos das Diretrizes da OCDE sobre Empresas Multinacionais. [...] A característica essencial de um MNE é, de acordo com esta definição, a capacidade de coordenar as atividades entre as empresas em mais de um país. Há outros fatores que não são decisivos. [...]”.

177 Tradução livre: “4(3). [...] Designam habitualmente firmas ou outras entidades estabelecidas em mais de um país e ligadas de tal modo que possam coordenar suas atividades de várias maneiras. Embora uma ou mais dessas entidades possa exercer influência significativa nas atividades das outras entidades, seu grau de autonomia dentro da empresa pode variar consideravelmente de uma empresa multinacional para outra. Podem ser de domínio privado, público ou misto. As Linhas Diretrizes são dirigidas a todas as entidades que compõem uma empresa multinacional (controladoras e/ou unidades locais). Segundo a repartição de responsabilidades entre elas, espera-se das diversas entidades cooperação e assistência recíproca para facilitar a observância das Linhas Diretrizes.”
} 
Diretrizes. [...]"178. De fato, uma ideia aproximada, com referência sumária à coordenação de atividades em mais de um país, já se mostra suficiente para indicar o cerne da preocupação do documento; ademais, pode-se dizer que é absolutamente compatível com a visão da professora Perrone-Moisés, e também com o consenso atingido na definição contida no Código de Conduta apresentado à negociação no contexto da ONU, mais genérica e ampla ${ }^{179}$.

Outro ponto a ser mencionado relaciona-se à disposição contida no item “4”(2000, ou “5”, 2011):

The Guidelines are not aimed at introducing differences of treatment between multinational and domestic enterprises; they reflect good practice for all. Accordingly, multinational and domestic enterprises are subject to the same expectations in respect of their conduct wherever the Guidelines are relevant to both ${ }^{180}$.

O comando é amenizado pelo item seguinte, reconhecendo que empresas pequenas e médias podem não ter as mesmas capacidades que as maiores ${ }^{181}$. Mesmo assim,

${ }^{178}$ Tradução do seguinte texto original: "A precise definition of multinational enterprises is not required for the purposes of the Guidelines. These enterprises operate in all sectors of the economy. [...]"

179 PERRONE-MOISÉS, Cláudia. O código de conduta da ONU para as empresas multinacionais instrumento jurídico de regulamentação das relações econômicas internacionais, p. 32.

Além disso, convém mencionar que, na versão de 1983, a redação do projeto é a seguinte:

“1. (a) [The term 'transnational corporations' as used in this Code means an enterprise, comprising entities in two or more countries, regardless of the legal form and fields of activity of these entities, which operates under a system of decision-making, permitting coherent policies and a common strategy through one or more decision-making centres, in which the entities are so linked, by ownership or otherwise, that one or more of them may be able to exercise a significant influence over the activities of others, and, in particular, to share knowledge, resources and responsibilities with the others.]

[The term 'transnational corporation' as used in this Code means an enterprise whether of public, private or mixed ownership, comprising entities in two or more countries, regardless of the legal form and fields of activity of these entities, which operates under a system of decision-making, permitting coherent policies and a common strategy through one or more decision-making centres, in which the entities are so linked, by ownership or otherwise, that one or more of them [may be able to] exercise a significant influence over the activities of others, and, in particular, to share knowledge, resources and responsibilities with the others.]" (Disponível em: <http://unctad.org/sections/dite/iia/docs/Compendium/en/13\%20volume\%201.pdf>. Acesso em: 30 out. 2012).

${ }^{180}$ As Linhas Diretrizes não almejam estabelecer diferenças de tratamento entre empresas multinacionais e domésticas; refletem práticas adequadas para todos. Por conseguinte, empresas multinacionais e domésticas são sujeitas às mesmas expectativas relativas à sua conduta em todo lugar onde as Linhas Diretrizes forem aplicáveis a ambas as categorias.

181 “5. Os governos desejam encorajar a maior observância possível dessas Linhas Diretrizes. Embora seja admitido que pequenas e médias empresas possam não ter as mesmas capacidades que empresas maiores, os governos aderentes às Linhas Diretrizes lhes aconselham seguir as recomendações das Linhas Diretrizes tão amplamente quanto possível." - Tradução livre do seguinte original: "5. Governments wish to encourage the widest possible observance of the Guidelines. While it is acknowledged that small - and medium-sized 
há um evidente convite aos Estados para que envolvam mesmo as empresas não caracterizáveis como multinacionais no processo de promoção das Diretrizes. De fato, essa orientação faz sentido no contexto da promoção de um mercado mais saudável e equilibrado.

Nesses termos, verifica-se que as Linhas Diretrizes objetivam um espectro amplo e genérico de empresas, induzindo os Estados aderentes a assumir uma nova função que combine a harmonização da legislação interna com a promoção de um comportamento determinado por padrões internacionalmente definidos. A questão que permanece é: terá o Estado legítima estrutura jurídico-normativa para assumir oficialmente a referida missão, que afeta interesses privados?

\subsection{A Prática das Diretrizes e do PCN}

Segundo a Decisão do Conselho da OCDE C/MIN(2011)11, o PCN tem o encargo de resolver as questões que possam surgir, envolvendo a implementação das Diretrizes. Os princípios lançados pelo documento são os da imparcialidade, previsibilidade, equidade, além da compatibilidade com os princípios e padrões das Diretrizes. Nesse contexto, tem-se a expectativa que o PCN desempenhe a função de fórum e assistente dos atores envolvidos - comunidade empresarial, organizações, inclusive as de trabalhadores, entre outros.

As ações do PCN no desenvolvimento de sua missão devem se dar, por disposição expressa, em face de questões originadas em países aderentes ou não, conforme item "5", da letra "C", "I", do Guia de Procedimentos: "5. If issues arise in non-adhering countries, take steps to develop an understanding of the issues involved, and follow these procedures where relevant and practicable" ${ }^{, 182}$.

Em termos práticos, espera-se que o PCN faça uma avaliação inicial das questões que lhe sejam levadas, declarando as razões pelas quais o PCN considere que elas mereçam ou não ser examinadas. No caso de se considerar pertinente determinada questão, o PCN deve oferecer-se para ajudar as partes a chegar a uma solução negociada. Trata-se,

enterprises may not have the same capacities as larger enterprises, governments adhering to the Guidelines nevertheless encourage them to observe the Guidelines' recommendations to the fullest extent possible."

${ }^{182}$ Tradução extraoficial (OCDE): "5. Se as questões forem suscitadas em países não aderentes, tomará medidas para se alcançar o entendimento sobre as questões envolvidas, seguindo os presentes procedimentos quando relevante e praticável." 
nesse sentido, de uma sugestão inicial de aproximação e solução negociada, compatível com os princípios básicos que norteiam a atuação da OCDE. Nessa fase, admite-se a colaboração de outros atores relevantes, especialistas ou até do PCN de outro país. Para os casos de dúvidas na interpretação das Diretrizes, o Comitê de Investimentos pode ser acionado.

Se a questão não for resolvida nessa primeira fase, caberá ao PCN oferecer acesso a outras soluções também pautadas no consenso, embora mediadas. Nesse rol estão a conciliação e a mediação ${ }^{183}$, segundo concordância das partes envolvidas.

Concluído um procedimento de conciliação, os resultados devem ser publicados, relevando-se a necessidade de proteger informações empresariais confidenciais e as que afetem terceiros. Também ficam condicionadas as informações atinentes aos acordos celebrados entre as partes, que só serão divulgadas com a anuência dos envolvidos.

No caso de um acordo pôr fim a uma questão, o relatório do PCN deverá conter, no mínimo, as questões abordadas, os procedimentos iniciados pelo PCN e a obtenção do acordo.

Já nos casos em que não se chegue a um acordo, o Guia de Procedimentos determina que uma declaração emitida pelo PCN, contendo a descrição das questões envolvidas, as razões pelas quais foram consideradas merecedoras de mais exames e quais as providências adotadas pelo sistema. Conforme o caso, além de fazer recomendações para a observância das Diretrizes, o PCN deve abordar os motivos pelos quais o acordo não foi possível - a isso será atribuído publicidade.

Dada a relação entre o Comitê de Investimentos e os PCNs, o Guia de Procedimentos faz ainda uma importante recomendação: o "PCN notificará os resultados de seus procedimentos de instâncias específicas ao Comitê de Investimentos"184.

Embora o PCN tenha a função de apurar de forma transparente, e de comunicar os eventos relevantes envolvendo as Diretrizes, há uma disposição no Guia de Procedimentos restritiva da publicidade. Na verdade, o Guia de Procedimentos prevê que, enquanto a questão estiver sendo resolvida ao nível da solução negociada entre as partes,

\footnotetext{
${ }^{183} \mathrm{O}$ texto assim se refere: "Offer, and with the agreement of the parties involved, facilitate access to consensual and non-adversarial means, such as conciliation or mediation, to assist the parties in dealing with the issues" (sem grifo no original).

${ }^{184}$ O texto diz: "The NCP will notify the results of its specific instance procedures to the Committee in a timely manner". Nos termos do documento de junho de 2000: "1. Cada Ponto de Contato Nacional relatará anualmente suas atividades ao Comitê”.
} 
naquela fase em que é possível o envolvimento de outros atores relevantes, especialistas ou até do PCN de outro país, o caso não será levado ao conhecimento público, assumindo o caráter de confidencial. As partes só estão liberadas para tornar público o caso se ao final dessa etapa não houver nenhum acordo, e ainda assim, como regra, desde que não revelem informações de outra parte cujo acesso decorreu do procedimento. De modo geral, pode-se dizer que a divulgação de informações sobre o caso levado ao PCN deve servir à saúde do sistema. Pretende-se, com isso, preservar a confiança no sistema, de modo que possam dialogar de forma aberta e favorável ao consenso.

As fases da atuação do PCN podem ser classificadas em fase prévia, de apreciação da pertinência do caso; se aceito, o PCN deve atuar na aproximação das partes para que se componham de forma negociada, com a possível colaboração de outros atores; não havendo sucesso nessa fase de negociação, cabe ao PCN promover uma apuração detalhada do caso, elaborando, em qualquer caso, um relatório específico.

\subsection{Os Casos do PCN Brasileiro}

Segundo o Relatório Anual, duzentas e vinte e quatro instâncias específicas procedimento para apuração de denúncias sobre inobservância das Diretrizes - já haviam sido instauradas em todo o mundo perante o PCN e, dessas, doze foram no PCN brasileiro $^{185}$.

185 OECD. Annual Report on the OECD Guidelines for Multinational Enterprises 2010 - Corporate Responsibility: Reinforcing a Unique Instrument, Structure of National Contact Points, p. 25. As reclamações relatadas em 2010 são as doze seguintes, às p. 218/219 do documento:

"1. Representação dos trabalhadores nos sindicatos

26-09-2003

IV. Employment and Industrial Relations, art. 1

Queixa resolvida - Declaração final

2. Construção de uma barragem afetando o meio ambiente e as populações locais

2004

V. Environmental

Em andamento, impasse na negociação

3. Questões trabalhistas e ambientais

8-05-2006

V. Environmental, art. 1 e 3 
Após uma longa mediação, o PCN Brasileiro decidiu encerrar o caso envolvendo a Shell com um abrangente Relatório em português

Declaração final

4. Dispensa de trabalhadores

26-09-2006

IV. Employment and Industrial Relations, art. 6

Concluído - declaração final

5. Recusa de negociação com sindicato

6-03-2007

IV. Employment and Industrial Relations, art.1(a), 2(a,b,c), 3 e 8

Em andamento

Lista de questões respondidas pela empresa; fase de manifestação do sindicato

6. Dispensa de trabalhadores

07-03-2007

II. General Policies, art. 2; IV. Employment and Industrial Relations, art. 1(a), 2(a), 4(a), 7 e 8

Em andamento

Conclusão do procedimento aguarda decisão judicial

7. Recusa de negociação com sindicatos

19-04-2007

IV. Employment and Industrial Relations, art. 1(a,d), 2(a,b,c), 3, 4 (a,b) e 6

Em andamento

8. Demissão de representante sindical sem justa causa

Abril, 2007. Essa reclamação tem como especificidade o fato de que o problema tratado pelo PCN brasileiro ocorreu no Paraguai.

II. General Policies, IV. Employment and Industrial Relations

Em andamento

9. Falta de negociações para acordo de trabalho

Julho, 2007

IV. Employment and Industrial Relations

Em andamento

10.Impedimento de manifestação de greve bancária

Setembro, 2009

IV. Employment and Industrial Relations, art. 7 e 8

Em andamento - sobanálise do Grupo Interministerial do PCN Brasileiro

11. Uso de brechas legais para impedir a presença de lideres sindicais no banco

Setembro, 2009

I., Concepts and Principles, art.7; IV. Employment and Industrial Relations, 8

Em andamento - sob análise do Grupo Interministerial do PCN Brasileiro

12. Impedimento de dialogo entre sindicato e companhia em caso de demissão de um empregado

Abril, 2010 
Os casos mais recentes apresentados por entidades sindicais e aceitos pelo PCN brasileiro foram classificados como Reclamações PCN n ${ }^{\text {os }}$ 01/2010, 02/2010 e 03/2010. As duas primeiras foram opostas contra bancos, sendo um deles um banco brasileiro (fundado e formado por brasileiros no Brasil) e o outro, a operação brasileira de uma instituição europeia (que iniciou seus investimentos pela aquisição de outros bancos nacionais). Ambas as instituições estão entre as cinco maiores no País. Já a terceira reclamação foi oposta contra uma multinacional alemã.

Todos os casos referem-se a reclamações de entidades sindicais contra posturas das empresas que seriam injustamente limitadoras do exercício do direito de greve. As reclamações fundaram-se no tópico IV das Linhas Diretrizes (Emprego e relações industriais), mais especificamente no que refere-se a atividade e representação sindical. Na última das reclamações, há insurgência contra a interposição de instrumento judicial denominado Interdito Proibitório - instrumento utilizado para impedir a turbação da posse. O caso foi assim fundamentado, segundo Declaração de Encerramento de Alegação de Inobservância (Caso BASF (22.06.10) - Reclamação PCN nº 03/2010):

De acordo com os alegantes, a empresa alemã utilizou brechas jurídicas, denominadamente o Interdito Proibitório, para impedir a presença de dirigentes sindicais em suas unidades, e não utilizou do Diálogo Social na ocasião de demissão por justa causa de um Representante dos Trabalhadores/as legitimamente eleito.

Ressalte-se que o caso foi encerrado à vista do pedido dos reclamantes, que apresentaram um documento de acordo celebrado com a reclamada, cujo teor era o seguinte, segundo a Declaração de Encerramento da Alegação:

\footnotetext{
Dentre os compromissos firmados entre a multinacional BASF S.A. e os trabalhadores estão melhores condições de diálogo com os representantes dos trabalhadores em caso de advertência e/ou suspensão dos representantes ou mesmo em casos de demissões por justa causa e participação da Rede de Trabalhadores na integração de novos trabalhadores, quando houverem reuniões de integração.
}

Verifica-se, com isso, que o PCN tem ganhado relevância, notadamente da perspectiva das relações de emprego, já que a maioria das reclamações processadas referese a essa matéria. Nesse contexto, destaca-se a atuação de sindicatos que utilizam o PCN

IV. Employment and Industrial Relations

Em andamento - sob análise do Grupo Interministerial do PCN Brasileiro.” 
como mais um instrumento de pressão no processo de afirmação dos interesses que consideram adequados.

Interessa, ademais, mencionar que o PCN nº 01/2006, à semelhança do $\mathrm{n}^{\mathrm{o}}$ 03/2010, tem como particularidade referir-se a situações que já envolvem tratamento judicial. No caso do PCN n⿳o 01/2006, dentre as alegações da principal empresa envolvida está a de que as responsabilidades sobre os fatos relacionados são objeto de tratamento judicial; no caso do PCN n⿳ำ 03/2010, por sua vez, a insurgência envolve a não aceitação de se recorrer a ação judicial para solucionar um conflito trabalhista.

Com efeito, no caso do PCN n⿳o 03/2006, em que já há um relatório final, é possível constatar haver respeito à organização institucional:

Com relação aos pontos aportados pela Shell, o Ponto de Contato Nacional (PCN) considerou pertinentes as alegações da Shell a respeito da inconveniência de uma atuação do órgão em relação às questões em apreciação na justiça e em outras esferas administrativas competentes. $\mathrm{O}$ PCN deve pautar sua atuação buscando não interferir nas investigações levadas a cabo pela justiça, fato que poderia inclusive ensejar inconvenientes situações de conflito institucional entre poderes, justamente o objetivo contrário das "Diretrizes da OCDE para Empresas Multinacionais" $" 186$.

A despeito do apontado, o PCN procura fazer recomendações, com o propósito de colaborar da melhor forma para a solução do caso, prestigiando as Linhas Diretrizes:

Não obstante essa constatação, julgou-se que havia espaço para atuação do PCN no presente caso, de maneira a representar um possível foro de diálogo entre as partes opostas, reduzindo conseqüentemente os antagonismos e ajudando-os a encontrar alternativas possíveis para remediar a situação-problema que foi apresentada ${ }^{187}$.

O PCN procurou, nesse sentido, mediar um diálogo entre as partes, embora não tenha sido capaz de produzir um resultado concreto, dado que os reclamantes - segundo o relatório - propuseram soluções muito genéricas. Mesmo assim, o PCN reforçou as recomendações de boas práticas:

Ressalta-se, por derradeiro, que em virtude das supracitadas conversações e reuniões efetuadas com gerentes da Shell em que o PCN estimulou e ressaltou a importância de ações de responsabilidade sócio-corporativa da

\footnotetext{
${ }^{186}$ BRASIL. PCN. Relatório Final da Reclamação $n^{\circ}$ 01/2006.

${ }^{187}$ Ibid.
} 
multinacional rumo à população de Vila Carioca e à região do entorno, foram realizados os projetos sociais abaixo discriminados, patrocinados pela Shell. Embora esses projetos não estejam vinculados à questão objeto da Reclamação, o PCN julgou que o estímulo a empreendimentos de responsabilidade sócio-corporativa direcionados à população de Vila Carioca representaria uma maneira de amainar os antagonismos e as diferenças existentes entre os pólos antagônicos na presente Reclamação, contribuindo, portanto, para que se pudesse iniciar um processo de conversações. [...] $]^{188}$

Veja-se que, de fato, há movimentação do PCN brasileiro. Nesse sentido, no ano de 2010, houve três reclamações novas, em que uma delas foi objeto de relatório final em agosto de 2011 (Reclamação PCN no 03/2010) ${ }^{189}$. Ademais, é notório que os sindicatos têm considerado o mecanismo um meio interessante de estabelecer diálogo e até mesmo ao que demonstra - exercer pressão sobre as companhias.

\footnotetext{
${ }^{188}$ BRASIL. PCN. Relatório Final da Reclamação no 01/2006.

${ }^{189}$ As proponentes CUT e Rede de Trabalhadores(as) na BASF América do Sul apresentaram pedido de cancelamento da reclamação, conforme consigna o respectivo Relatório: "Em 28/08/2011, foi recebida pelo PCN carta formal da Central Única dos Trabalhadores (CUT) e da Rede de Trabalhadores(as) na BASF América do Sul solicitando a suspensão e o cancelamento da reclamação realizada em desfavor da multinacional BASF S.A. Junto às cartas, também foi enviada carta de compromissos da BASF S.A. assumidos com os representantes da Rede INTRAB (Intersindical Nacional dos Trabalhadores na BASF)."
} 


\section{CAPÍtULO 6}

\section{O PROBLEMA DAS DIRETRIZES NO BRASIL}

\subsection{Análise: a Implantação das Diretrizes e do PCN no Brasil}

Conforme já avaliado, a formação plurilateral da Declaração que contém as Diretrizes lhe dá uma materialidade política diferenciada, importando em consequências relevantes no tocante à sua legitimidade e eficácia. Anote-se que se trata não de uma autoridade a sustentar a norma, mas sim da colaboração e aceitação pelas partes, conforme já comentado ao se fazer referência a Bodansky ${ }^{190}$.

A corroborar a força decorrente dessa natureza das Diretrizes, tem-se a sistemática da OCDE, na fiscalização de sua implementação pelo PCN. Como se sabe, o comportamento dos particulares em relação às Diretrizes é fiscalizado pelos PCNs, e os próprios PCNs relatam suas atividades ao Comitê de Investimentos, de modo que se estrutura um mecanismo de pressão - típico da OCDE.

Esse sistema - Diretrizes e PCN - existe no Brasil, onde exerce uma função aparentemente acatada pelas empresas multinacionais (não há notícia de insurgência judicial contra o referido sistema), sem, contudo, uma identidade jurídica clara. Ou melhor, sabe-se que há aceitação voluntária aos termos da Declaração sobre o Investimento Internacional e as Empresas Multinacionais, a despeito de não contar com um ato oficial que expresse essas normas em idioma nacional - o documento traduzido é considerado extraoficial e está disponível no já mencionado sítio do Ministério da Fazenda, sem um ato oficial transcrevendo seus termos.

Há, além da questão sobre a forma de integração desse direito instituído pelas Diretrizes (conteúdo), outra pendente, alusiva à criação do PCN, no Brasil, que se deu simplesmente pela edição da Portaria nº 92/2003 (ato administrativo), na estrutura do Ministério da Fazenda.

O Brasil, nesse sentido, comprometeu-se, perante a OCDE, a observar os termos da Declaração e implantar o PCN para a promoção das Diretrizes. Esse compromisso foi assumido no contexto de sua participação no Comitê de Investimentos.

\footnotetext{
${ }^{190}$ BODANSKY, Daniel. The legitimacy of international governance: a coming challenge for international environmental law? The American Journal of International Law, v. 93, n. 3, p. 596-624.
} 
Se, por um lado, da perspectiva da ordem internacional o ato foi eficaz, no que tange à assunção do compromisso e à participação do Brasil no referido Comitê da OCDE; por outro, do ponto de vista da ordem interna, algumas questões merecem análise.

Em primeiro lugar, a assunção de compromissos onerosos na ordem internacional, pelo Brasil, depende de manifestação congressual. Nesse caso, é discutível a regularidade do ato de participação brasileira em referido Comitê ante a disposição do artigo 49, inciso I, da Constituição Federal (conforme visto no Capítulo 3) - seja a disposição adequada ou não para esses casos, ela existe. Em segundo lugar, a Declaração contém o compromisso, dos aderentes, de promover aqueles valores (das Diretrizes) em seu território, sendo um compromisso forte no que se refere à instalação do PCN. Ou seja: se, por um lado, é às empresas que as normas Diretrizes estão destinadas, por outro, é do Estado o compromisso de criar o PCN e de promover as Diretrizes.

A considerar, contudo, o instrumental normativo e jurisprudencial contemporâneo, a legitimidade das Diretrizes, assim como o ato de adesão à Declaração (ato internacional) não encontrariam sustentação imediata no direito brasileiro, considerando-se a preterição daquelas formalidades constitucionais que incluem aprovação congressual e expedição de decreto presidencial. Com isso, mesmo considerando-se que o ato materialmente representa manifesta convergência de intenções com a sociedade civil global, e é materialmente compatível com o sistema constitucional e normativo brasileiro, ainda haveria uma questão fundamental a ser analisada: quais os parâmetros e normas para orientar a interação de um ato de organização internacional como esse, no sistema de direito brasileiro?

De fato, é conveniente pensar nas formas de ampliação das hipóteses para além da literalidade do artigo 49, inciso I, da Constituição Federal. Nesse contexto, é oportuno lembrar que há, como refere boa doutrina, uma posição defensora de tratados que dispensam o processo de apreciação pelo Congresso Nacional, no Brasil; mas mesmo essa posição abrange restritas hipóteses, como a do acordo executivo, previamente autorizado pelo Congresso, ou o de pequeno impacto jurídico e político, como ressalta Dallari ${ }^{191}$ - por recurso à interpretação constitucional. Por isso, convém esclarecer que:

Assim, do ponto de vista da realidade das relações internacionais do Brasil, pode-se concluir de forma pacífica que a exigência do rito apresentado inicialmente - que contempla a apreciação das normas

${ }^{191}$ DALLARI, P. B. de Abreu. Constituição e tratados internacionais, p. 92. 
convencionais internacionais pelo Congresso Nacional - alcança senão todos, a quase-totalidade dos tratados celebrados pelo Brasil, em especial aqueles que, por estatuírem normas de natureza geral e abstrata, vão ter relevância maior no trato do tema da relação entre o Direito Internacional Público e o direito interno ${ }^{192}$.

A lógica da coparticipação legislativa no processo de celebração de atos internacionais é a forma predominante e, como ensina Dallari, "aparentemente, não se vislumbra a perspectiva de alteração dessa fórmula, de resto mais consentânea com a preocupação atual do constitucionalismo brasileiro de evitar a hipertrofia do Poder Executivo" $" 193$.

As Diretrizes têm um potencial marcante, com influência direta na atuação dos agentes privados e, à primeira vista, seria temerário incluí-las sumariamente entre os que dispensam o processo congressional. E, embora as Diretrizes instituam apenas normas de conduta, e que sejam "consistentes" com a legislação aplicável, trata-se de normas inseridas em um sistema de relevante pressão - elas se tornam quase um dever jurídico. Destaque-se, ainda, que a observância pelos particulares será fiscalizada por um mecanismo (PCN) instalado em um órgão da Administração Pública federal, em um processo que pode ser considerado de natureza sancionatória - ainda que não nas formas típicas de coação jurídica com restrição patrimonial ou de liberdade, mas de verdadeira censura. Em razão disso, deve haver um procedimento contraditório de apuração que, a despeito da formalidade ou não, prestigie o princípio constitucional do devido processo legal formal e material.

Importa comparar, nesse sentido, o sistema do PCN e das Diretrizes ao Código de Ética Profissional do Servidor Público Civil do Poder Executivo Federal, instituído pelo Decreto $\mathrm{n}^{\mathrm{o}} 1.171 / 1994$ e alterado pelo Decreto $\mathrm{n}^{\mathrm{o}}$ 6.029/2007. Isso porque esse Código de Ética contém normas de conduta que são, na verdade, padrões de observância a preceitos jurídicos já determinados pelo ordenamento. É exemplificativo o item "b", alínea XIV, que expressa senão o princípio da eficiência:

b) exercer suas atribuições com rapidez, perfeição e rendimento, pondo fim ou procurando prioritariamente resolver situações procrastinatórias, principalmente diante de filas ou de qualquer outra espécie de atraso na prestação dos serviços pelo setor em que exerça suas atribuições, com o fim de evitar dano moral ao usuário; [...]

\footnotetext{
${ }^{192}$ DALLARI, P. B. de Abreu. Constituição e tratados internacionais, p. 92.

${ }^{193}$ Ibid., loc. cit.
} 
A disposição também encontra paralelo na Lei $n^{0}$ 8.112/1990, notadamente no artigo 116:

Art. 116. São deveres do servidor:

I - exercer com zelo e dedicação as atribuições do cargo;

$[\ldots]$

$\mathrm{V}$ - atender com presteza:

a) ao público em geral, prestando as informações requeridas, ressalvadas as protegidas por sigilo;

b) à expedição de certidões requeridas para defesa de direito ou esclarecimento de situações de interesse pessoal;

c) às requisições para a defesa da Fazenda Pública.

Assim como as Diretrizes, as normas apontadas não inovam em termos de obrigações legais, mas instituem uma nova instância de controle, apta a adotar uma medida de caráter sancionatório - não é efetiva privação patrimonial ou de direitos, mas é dirigida contra os interesses do envolvido. A esse propósito, ressalte-se que o Código de Ética prevê a censura, enquanto o PCN prevê a publicidade às posturas adotadas pela empresa multinacional, seja no que tange à conduta contrária às Diretrizes e que tenha justificado a abertura da Reclamação, seja a respeito da postura da empresa em termos de tratamento da questão - do diálogo e das disposições em resolver - perante o PCN.

Sobre o Código de Ética, o Decreto que o instituiu prevê a criação de Comissões de Ética, nos seguintes termos:

\section{$[\ldots]$}

XVI - Em todos os órgãos e entidades da Administração Pública Federal direta, indireta autárquica e fundacional, ou em qualquer órgão ou entidade que exerça atribuições delegadas pelo poder público, deverá ser criada uma Comissão de Ética, encarregada de orientar e aconselhar sobre a ética profissional do servidor, no tratamento com as pessoas e com o patrimônio público, competindo-lhe conhecer concretamente de imputação ou de procedimento susceptível de censura.

Por fim, anote-se que o artigo 12 do Decreto $\mathrm{n}^{\mathrm{o}}$ 6.029/2007 reafirma os valores da garantia à ampla defesa e ao contraditório, estabelecendo parâmetros básicos para a promoção desses princípios. Nesse contexto, entende-se plenamente compatível o modelo processual do PCN com o modelo do referido Decreto, uma vez que o devido processo legal não depende exclusivamente da legalidade.

Saliente-se que, se, por um lado, há legitimidade na forma adotada para implementação das Diretrizes e do PCN, por outro, as relações cooperativas brasileiras, 
como a de que trata este estudo, poderiam ser excessivamente engessadas por uma desnecessária apreciação parlamentar.

Como se tem proposto ao longo deste trabalho, o relacionamento com a OCDE, notadamente com o Comitê de Investimentos, se estabeleceu após uma tentativa de aproximação mútua, uma decisão política; e essa decisão política requer uma adequação das políticas e dos sistemas internos do Estado para que, cumpridos os parâmetros mínimos, as relações com a OCDE possam ser elevadas em níveis de participação efetiva ou de membro. Nesse contexto, o atual nível de relacionamento com a OCDE conduz à adoção de medidas de aprimoramento das políticas e regras internas, não como uma inovação nas obrigações legais das empresas, mas como promoção de excelente padrão de respeito à legislação interna.

Destaque-se que o relacionamento estabelecido com o Comitê de Investimentos se insere em fase preparatória a uma eventual assunção efetiva de obrigações internacionais perante a OCDE - que pode acontecer ou não. E essa circunstância - embora conduza à formalização de compromissos que, se desatendidos, implicarão o rompimento de relações com a OCDE - não deve ser comparada com o ato de adesão efetiva - como participante de um Comitê (e não mero observador), ou membro da organização. São níveis diferentes, sendo o primeiro de construção e preparação e o segundo de assunção de ônus mais concretos e efetivos. $O$ tratamento e a visão jurídica devem ser, portanto, distintos.

Em outras palavras, deve-se admitir que a atuação brasileira no âmbito internacional não se resume à celebração de tratados - sempre sujeitos ao rito congressual, como já se sustentou neste estudo com amparo em Dallari -; e que ao lado deles há atos que não dependem da aprovação congressual, permitindo maior dinâmica nas relações internacionais sem, contudo, conferir poderes excessivos ao Executivo. É que, segundo construção que pode ser considerada coerente, o artigo $4^{\underline{o}}$, inciso IX, da Constituição Federal, que enuncia o princípio da cooperação internacional - e os atos de verdadeira cooperação dispensariam um controle tão cerrado pelo Poder Legislativo -, pode servir de base para o estabelecimento de relações com Estados estrangeiros e Organizações internacionais que não gerem inovações jurídicas. Ao contrário, as relações estabelecidas nesses moldes serviriam para dar efetividade aos valores jurídicos já enunciados no ordenamento brasileiro e que sejam comuns com Estados estrangeiros e organizações internacionais. 
Retoma-se assunto já abordado neste trabalho, a propósito de o princípio cooperativo estar entre os fundamentos da Carta da ONU, para salientar posição defendida por Peter Häberle, segundo o qual “o ‘direito comum de cooperação’ recebe dos direitos fundamentais os mais fortes impulsos, integra-os para 'tarefas da comunidade' e tem neles um garante confiável" ${ }^{\text {"194 }}$. Lembre-se que a Carta da ONU foi recepcionada pela ordem interna, e a integra. Para Häberle, a realização internacional conjunta de valores tidos como fundamentais e universais é um imperativo jurídico - como já tratado neste estudo. O autor opõe a utilização das fronteiras como um meio de subtração ao direito, pela maliciosa defesa do respeito à soberania. Considera, nesse sentido, que o direito estatal deve refletir valores humanitários comuns, os quais são sempre incompatíveis com a permissão que alguém se subtraia da aplicação do direito exatamente se escondendo da atuação estatal, sob o argumento de que as fronteiras limitam o poder soberano de persecução.

Nesse contexto, a Declaração, com suas Diretrizes, poderia ser encarada como parte de um esforço de afinamento ${ }^{195}$ entre os Estados em termos não de inovação legal, mas de efetivação de esforços conjuntos de promoção dos valores comuns tidos pelos ordenamentos jurídicos dos Estados, em relação às empresas multinacionais. Isso dar-se-ia de maneira a atenuar o aproveitamento dos limites territoriais como forma de escapar de maior efetividade na aplicação de um direito comum.

Desse ponto de vista, seria o caso não de se negar genericamente a necessária manifestação congressual, mas de se admitir outras formas de se estabelecer relações no âmbito internacional.

Trata-se, nesse caso, não de enxergar o que não foi dito, mas de relevar os conceitos de supranacionalidade, e mesmo encarar os conceitos principiológicos que procuram estabelecer as relações constitucionais entre o direito interno e o internacional como ponto de partida para desenvolvimento de uma teoria sensata e compatível com ideias muito atuais de constitucionalismo.

Entende-se, portanto, dispensável que atos internacionais de reafirmação e de promoção da efetividade do direito interno, perante instâncias internacionais, sejam objeto de manifestação congressual em termos de observância do artigo 49, inciso I, da

\footnotetext{
${ }^{194}$ HÄBERLE, Peter. Estado constitucional cooperativo, p. 70.

${ }^{195}$ Umberto Celli, ao se referir a Bela Balassa, faz uma observação útil e interessante: "Para autores clássicos como Bela Balassa, a cooperação incluiria várias medidas destinadas a harmonizar políticas econômicas e diminuir a discriminação entre os países." (CELLI JUNIOR, U. Teoria geral da integração: em busca de um modelo alternativo. In: MERCADANTE, A. A.; CELLI JUNIOR, U.; ARAÚJO, L. R. (Orgs.). Blocos econômicos e integração na América Latina, África e Ásia. Curitiba: Juruá, 2008. v. 1, p. 22).
} 
Constituição Federal. Isso porque não inovam a ordem jurídica, nem criam novo dever; ao contrário, só tornam mais efetiva e evidente a soberania interna na medida em que colaboram para a observância e cumprimento do direito interno. Os atos que inovem a ordem jurídica, ou que criem nova obrigação no plano internacional, por sua vez, devem seguir a regra geral, com a necessária participação parlamentar.

\subsection{O Problema das Diretrizes e do PCN perante o Direito Brasileiro}

Mesmo admitindo-se que o ato praticado pelo Brasil internacionalmente não chega a ser uma inovação na ordem jurídica, mas um compromisso de promover altos padrões de observância da legislação interna pelas empresas multinacionais, como uma forma cooperativa de promover o direito e de fortalecer sua própria soberania, ainda assim resta uma questão importante: os padrões de conduta, que partem do compromisso de respeito à ordem jurídica interna de forma categórica e sob interpretações morais e conservadoras, encontram-se expressos em um documento sem uma versão oficial em idioma português.

$\mathrm{Na}$ prática isso não chega a ser um problema, porque a tradução é suficientemente clara e precisa no tocante aos valores enunciados - já que não chega a haver regras detalhadas de comportamentos, mas diretrizes, não restando margem a dúvidas relevantes sobre o texto. E, como as empresas multinacionais são as principais envolvidas, é inegável que o idioma inglês seja acessível ao seu corpo diretivo.

De qualquer maneira, trata-se de uma situação bastante excepcional, sendo de se considerar que seria mais compatível com o ordenamento jurídico nacional se o documento tivesse uma tradução oficial em idioma português para fins de atuação do PCN brasileiro. Isso porque, embora não se esteja aqui falando de lei, trata-se de um conjunto normativo promovido e fiscalizado por um mecanismo instalado e operado por um órgão administrativo oficial.

Além disso, a propósito da criação do PCN, no Brasil, deve-se admitir que se trata de um compromisso decorrente da Declaração. E de fato é, mas a sua instalação em estrutura administrativa oficial não seria algo que dependesse ordinariamente de lei. Deuse, no entanto, por simples Portaria Ministerial, como uma função existente dentro do Ministério da Fazenda, com atuação segundo um procedimento criado pelo próprio PCN: há a Resolução PCN nº 01/2007. 
Há, de fato, uma base constitucional compatível com uma iniciativa dessa natureza. Nesse sentido, o artigo 174 da Constituição Federal trata da função do Estado como agente normativo e regulador da atividade econômica, exercendo a fiscalização, o incentivo e o planejamento, ainda que de forma indicativa. Pode-se dizer, portanto, que a atuação estatal, segundo o modelo proposto pela OCDE, é compatível com a ordem constitucional dado que não extrapola as exigências legais - mas reforça a observância das normas brasileiras - e efetiva o comando de atuação fiscalizadora, e até mesmo de incentivo.

Saliente-se, ainda, o fato de a jurisprudência do STF apontar para uma visão que admite a promoção da eficácia do texto constitucional por atos infralegais ${ }^{196}$, sem a necessidade absoluta e indispensável de um ato legal em sentido estrito mediando a norma constitucional e a norma regulamentar. No voto proferido pelo Ministro Carlos Ayres Brito, na ADC $12^{197}$, tratando da legitimidade do Conselho Nacional de Justiça de expedir normas primárias, ou seja, de expedir normas para cumprimento de preceito constitucional, a despeito da inexistência de lei - ordinária ou complementar -, prevalece a ideia de que os valores constitucionais devem ser prestigiados, mais do que uma lógica pautada na pirâmide kelseniana:

22. Acontece que as normas ditadas por essa lógica da mais abrangente irradialidade sistêmica admitem contemporização. Comportam atenuação, exatamente para ceder espaço a valores e interesses outros que, embora de menor compleição material, são relevantes o bastante para merecer um tratamento heterodoxo.

E o voto do Ministro termina por concluir que a exigência de atendimento de um princípio da estrita legalidade, que fosse tomado de modo anacrônico, negaria efetividade a valores constitucionais que não podem ser enjeitados.

A contribuição do Ministro Gilmar Mendes é muito conveniente, anotando-se a tradução que fez da obra de Konrad Hesse, com interesse específico para o seguinte trecho:

Em outros termos, o Direito Constitucional deve explicitar as condições sob as quais as normas constitucionais podem adquirir a maior eficácia possível, propiciando, assim, o desenvolvimento da dogmática e da

\footnotetext{
${ }^{196}$ Remissão pela Portaria às Linhas Diretrizes, cujo texto em português, conforme mencionado, encontra-se disponível no sítio eletrônico do PCN, mantido pelo Ministério da Fazenda (http://www.fazenda.gov.br/sain/pcnmulti/ocde.asp).

${ }^{197}$ BRASIL. Supremo Tribunal Federal. ADC 12. Relatoria Ministro Carlos A. Brito, julgamento em 20.08.2008.
} 
interpretação constitucional. Portanto, compete ao Direito Constitucional realçar, despertar e preservar a vontade de Constituição (WillezurVerfassung), que, indubitavelmente, constitui a maior garantia de sua força normativa. Essa orientação torna imperiosa a assunção de uma visão crítica pelo Direito Constitucional, pois nada seria mais perigoso do que permitir o surgimento de ilusões sobre questões fundamentais para a vida do Estado ${ }^{198}$.

Infere-se, assim, que a sistemática de promoção de valores pertinentes ao sistema jurídico brasileiro, por meio da adesão à Declaração que contém as Diretrizes, e à implantação do PCN, poderia sustentar-se a despeito de prévia aprovação congressual, não havendo, no plano abstrato, motivo para considerar qualquer invalidade jurídica ou preterição de processo formal.

\subsection{Consensualidade: o Conteúdo das Linhas Diretrizes}

As empresas multinacionais são atores internacionais dotados, em geral, de extremo poder econômico, capazes de influenciar decisões políticas e jurídicas. Além disso, são atores que atuam em diferentes realidades nacionais. É benéfico para o investimento, que exista um tratamento simétrico, destinado a lhes dar uma regulamentação geral e a lhes servir de referência sobre a qual regramento jurídico se sujeita uma ou outra de suas unidades. Isso é um elemento de segurança e previsibilidade, mas notadamente de criação de um ambiente concorrencial saudável. Pode ser favorável também aos Estados, como será possível verificar.

Em obra intitulada La refondation des Pouvoir, Mireille Delmas-Marty ${ }^{199}$ faz uma análise do reequilíbrio dos poderes, anotando, inicialmente, a preponderância dos atores econômicos, detentores de um poder econômico apto a fazer frente à autoridade estatal. Esses atores caracterizados como empresas multinacionais atuam a despeito das fronteiras nacionais, destacando o problema da falta de simetria entre os poderes políticos e os poderes econômicos, em face do espaço territorial. Diante desses problemas em escala global, a autora propõe:

\footnotetext{
${ }^{198}$ HESSE, Konrad. A força normativa da Constituição. Porto Alegre: Fabris, 1991. p. 27.

${ }^{199}$ DELMAS-MARTY, Mireille. La refondation des pouvoirs - les forces imaginantes du droit (III). Paris: Le Seuil, 2007.
} 
Seul la création d'un droit des affaires unifié à l"' chelle mondiale pourrait faire coïncider espace économique et territoire normatif, mais elle semble impossible tant qu'il n'existe pas de juridiction mondiale compétente en la matière. $[\ldots]^{200}$

A despeito de reconhecer as dificuldades de institucionalização de um ordenamento jurídico unificado para a atuação das empresas multinacionais, Mireille Delmas-Marty aponta uma tendência à internacionalização das responsabilidades desses atores econômicos. Cita, então, duas vias. A primeira, pela ultratividade territorial de normas estatais, a qual exemplifica lembrando que a Lei Sarbanes-Oxley (SOX) prevê a observância de determinadas obrigações pelas empresas cotadas em bolsa (norteamericana), a despeito de onde estejam atuando as filiais. A segunda, e que mais interessa ao presente estudo no momento, diz respeito efetivamente ao direito internacional:

D'où l'intérêt de la second voie, celle d'une expansion de responsabilité encadrée par le droit international conventionnel. Cette voie pourrait assurer une plus grande légitimité, car elle repose sur l'adoption multilatérale de normes communes, même si elle reste limitée à certains secteurs, comme la lutte contre la corruption internationale ${ }^{201}$.

Nesse contexto, a professora Cláudia Perrone-Moisés refere-se a alguns desses elementos que tornam tão apropriada a construção de um código de conduta, pautado em uma organização internacional, quando o assunto é atuação de empresas multinacionais. E pondera $^{202}$ :

\begin{abstract}
A realidade das empresas multinacionais é um fator complicador porque revela a falência dos pressupostos que serviram de base à elaboração dos modelos jurídicos do Direito Internacional clássico e confere novos dados às relações internacionais.
\end{abstract}

A Professora continua a discorrer sobre o assunto, sustentando:

\footnotetext{
${ }^{200}$ PERRONE-MOISÉS, Cláudia. O código de conduta da ONU para as empresas multinacionais instrumento jurídico de regulamentação das relações econômicas internacionais, p. 156. Tradução livre: "Apenas a criação de um direito dos negócios unificado em escala mundial poderá fazer coincidir os espaços econômico e territorial normativo; mas parece impossível até que haja jurisdição competente em esfera global.".

${ }^{201}$ Ibid., p. 158: "Daí o interesse pela segunda via, o da expansão da responsabilidade regulada pelo direito internacional convencional. Esta rota pode proporcionar uma maior legitimidade, pois se dá com base na adoção multilateral de normas comuns, mesmo que seja limitada a determinados setores, tais como a luta contra a corrupção internacional."

${ }^{202}$ Ibid., p. $56 / 57$.
} 
A criação de um código de conduta como o das empresas multinacionais demonstra a necessidade de uma adaptação do Direito à nova realidade das relações internacionais, onde as empresas multinacionais desempenham um papel importante ${ }^{203}$.

A mera edição de normas, no entanto, não basta. É necessária uma ação efetiva nos Estados envolvidos na afirmação de suas soberanias como instrumentos de afirmação dos direitos. A esse propósito, Zemanek destaca que as organizações internacionais são as únicas estruturas existentes nas quais um sistema de constrição (enforcement) coletivo das obrigações internacionais pode ser instituído - embora reconheça as deficiências de uma organização internacional no campo do enforcement. Daí que - como se viu - os mecanismos da OCDE, cuja eficiência é reconhecida, criam uma expectativa muito positiva no envolvimento dos Estados na instituição de um código de conduta para as empresas multinacionais, notadamente pelo ambiente cooperativo ${ }^{204}$.

Nesse ambiente cooperativo, portanto, há a criação de um regime geral - ou homogêneo - que atende os anseios dos atores ali reunidos ${ }^{205}$ - resultando em um direito

203 PERRONE-MOISÉS, Cláudia. O código de conduta da ONU para as empresas multinacionais instrumento jurídico de regulamentação das relações econômicas internacionais, p. 57.

${ }^{204}$ ZEMANEK, Karl. General course on public international law. R.C.A.D.I., t. 266, 1997-1998, p. 293: "International organizations are the only existing structures to which the orderly collective enforcement of international obligations could be entrusted. However, as has been described in some detail, enforcement is not the best-developed feature of international organizations. Where it is provided for, either in the constitution of an organization or in a convention adopted under its auspices, it functions in an indirect way: by establishing some sort of international control, mostly in the form of a reporting system that is sometimes strengthened by compliance procedure, organizations try to enlist the pressure of public opinion for inducing compliance.” Tradução livre: “As organizações internacionais são as únicas estruturas coletivas existentes às quais a execução ordenada de obrigações internacionais poderia ser confiada. No entanto, como tem sido descrito com algum pormenor, a constrição (enforcement) não é a característica mais desenvolvida das organizações internacionais. Onde é previsto, quer na constituição de uma organização ou de uma convenção adotada sob os seus auspícios, funciona de forma indireta: mediante a criação de algum tipo de controle internacional, principalmente na forma de um sistema de comunicação que por vezes é reforçada pelo procedimento de cumprimento; as organizações tentam mobilizar a pressão da opinião pública para induzir o cumprimento."

205 Ibid., p. 54/55: “[...] Constituem o resultado de uma coordenação interestatal, mediada por uma Organização Internacional, com a qual se pretende criar uma relação de cooperação entre Estados e agentes privados e que, mesmo adotando a forma de resolução, com pequeno grau de positividade, podem vir a constituir fontes importantes do Direito Internacional. [...]”.

"Conforme aponta Salcedo, o que se verifica hoje na sociedade internacional é sua crescente institucionalização. O papel crescente das Organizações Internacionais na elaboração do Direito Internacional, sem deslocar a soberania dos Estados nem eliminar a relevância de seu consentimento na criação das normas jurídicas, corrige os traços de descentralização que caracterizam o Direito Internacional coletivo, menos sensível do que o atual às exigências de interdependência e cooperação, assim como aos interesses coletivos da comunidade internacional em seu conjunto. (J. A. Carrilo Salcedo, El derecho internacional em um mundo em cambio. Madrid, Tecnos, 1985, p.98).”

E, ainda, na p. 20: "Como vimos, a empresa multinacional sofre a incidência de diversos ramos do Direito. Ocorre que essa heterogeneidade de procedências normativas dificulta um eficaz reconhecimento das normas que devem reger a conduta dessas empresas. Somos assim levados a pensar que a única maneira de homogeneizar o tratamento do problema suscitado pela empresa multinacional seria uma coordenação 
muito legítimo e, no dizer de Mireille Delmas-Marty, autorreflexivo ${ }^{206}$ :

En somme, une nouvelle forme de ces codes de conduite qui ont pu être analysés comme la manifestation d'un droit autorégulé et réflexif.

[...] une efficacité variable selon qu'ils sont élaborés sous l'égide de la Chambre de Commerce Internationale (CIC) ou en partenariat avec des institutions internationales, comme l'OCDE, l'OIT ou, plus récentement, l'ONU.

É verdade que, como aponta Muchlinski ${ }^{207}$, a iniciativa das Linhas Diretrizes da OCDE pode ser vista como corporativista. Sob esse aspecto, não se afaste o risco da captura dos interesses nacionais pela influência de outros atores dotados de mais poder no processo de consenso - o que merece intensa observância dos envolvidos. De fato, ela é lançada pelos Estados das sedes das multinacionais e, como efetivamente lembra o referido

interestatal por meio de normas de Direito Internacional Público, criando-se uma relação de cooperação entre os Estados e as empresas multinacionais. (cita Celso Lafer. Introdução à guisa de prefácio in Luiz Olavo Baptista, Empresa Transnacional e Direito, São Paulo, Ed. Revista dos Tribunais, 1987)”.

${ }^{206}$ DELMAS-MARTY, Mireille. La refondation des pouvoirs - les forces imaginantes du droit (III), p. 154. Tradução livre: Em suma, uma nova forma de códigos de conduta que pudesse ser analisada como uma manifestação de um direito autorregulado e reflexivo. [...] uma eficácia verdadeira dado que são elaborados sob os auspícios da Câmara de Comércio Internacional (ICC) ou em parceria com instituições internacionais como a OCDE, a OIT e, mais recentemente, as Nações Unidas.

${ }^{207}$ MUCHLINSKI, Peter T. Multinational enterprises and the law, p. 659: "The threat of increased host country control over the activities of MNEs was further accentuated by the waves of nationalizations in 1960s and early 1970s, and by the oil crisis precipitated by the activities of OPEC in 1973.To counter these developments the OECD ministers, urged on by US Government, decided to adopt their own policy on MNEs, which it was hoped would influence the UN's attempts at 'codification' to move away from a highly regulatory position of MNEs control.

A second reason for the move towards the adoption of OECD Guidelines on MNEs was to meet demands form within the OECD countries for greater control over MNEs. Canada, Holland, and the Scandinavian states supported such controls. Furthermore, demands for controls over MNEs were articulated by the trade unions through the Trade Union Advisory Committee (TUAC) of the OECD. The above mentioned Member Countries and the unions wanted a legally binding code. This was counterbalanced by calls from the representatives of the business community, articulated through the Business and Industry Advisory Committee to the OECD (BIAC), for greater emphasis on the removal of obstacles to foreign direct investment. Thus the guidelines can be seen as a 'corporatist' initiative." Tradução livre: "A ameaça de maior controle dos países anfitriões sobre as atividades das empresas multinacionais foi ainda mais acentuada pelas ondas de nacionalizações em 1960 e início dos anos 1970, e pela crise do petróleo precipitada pelas atividades da OPEP em 1973. Contra esses movimentos, os ministros da OCDE, a pedido do governo dos EUA, decidiram adotar a sua própria política de empresas multinacionais, que se esperava pudesse influenciar as tentativas da ONU de 'codificação' para se afastar de uma posição altamente reguladora de controle das EMNs. Uma segunda razão para o movimento de adoção de orientações da OCDE sobre empresas multinacionais foi para atender demandas formadas dentro dos países da OCDE para maior controle sobre as empresas multinacionais. Canadá, Holanda e os Estados escandinavos defendiam tais controles. Além disso, as demandas por controles sobre as empresas multinacionais foram articuladas pelos sindicatos por meio do Sindicato Advisory Committee (TUAC) da OCDE. Os países-membros acima mencionados e os sindicatos queriam um código juridicamente vinculativo. Este foi contrabalançado por chamadas dos representantes da comunidade empresarial, articuladas por meio do Comitê Consultivo de Negócios e Indústria da OCDE (BIAC), para maior ênfase na eliminação dos obstáculos ao investimento direto estrangeiro. Assim, as diretrizes podem ser vistas como uma iniciativa "corporativista"'. 
autor, coincide com um momento de receio diante da onda de nacionalização (anos 19601970); mas a participação ativa dos sindicatos - inclusive na implementação das Linhas Diretrizes - denota que não se converteram em instrumento de supremacia das multinacionais. Ao contrário, apresentam-se como um meio de diálogo valioso e um instrumento oportuno em face da multinacionalidade desses atores ${ }^{208}$.

Em razão disso, há notória percepção de legitimidade do instrumento, o que lhe confere especial efetividade ${ }^{209}$. E o mecanismo do PCN mostra-se bastante compatível com as necessidades geradas pela natureza das empresas multinacionais. Nesse contexto, as Linhas Diretrizes revelam-se como um verdadeiro consenso voltado, de um lado, à garantia dos investimentos oriundos dos países desenvolvidos e, em contrapartida, ao compromisso de as multinacionais respeitarem a soberania dos países receptores dos investimentos - e mesmo dos Estados das sedes dessas empresas, que mantêm certo controle sobre suas atividades, mesmo extraterritorialmente.

\subsection{PCN e Atuação Administrativa}

Como foi possível observar, as Linhas Diretrizes podem ser encaradas como um consenso internacional em matéria de empresas multinacionais. Os padrões ali definidos procuram consignar valores comumente aceitos, mas mais do que isso, consolidam o consenso dos Estados-membros da OCDE e, ainda, de outros aderentes.

Saliente-se que a atuação das empresas multinacionais é a razão primeira da criação das Linhas Diretrizes. Há, sem dúvida, dupla função na criação de padrões de

\footnotetext{
${ }^{208}$ As Linhas Diretrizes constituem regras criadas no seio de uma organização internacional, que permitem uma adesão voluntária; a formação do direito, nesse caso, contém um elemento a mais de legitimidade. Não se trata de um conjunto de acordos celebrados para situações específicas, mas de um conjunto de regras gerais e amplas para relações envolvendo multinacionais - não se trata, portanto, de uma lex specialis, mencionada por Muchlinski. Segundo esse autor: "Thus BITs and other ILAs represent a particular legal instrument seeking to solve a specific problem of international economic relations and creating an effective lex specialis between the parties" (MUCHLINSKI, Peter T. Multinational enterprises and the law, p. 702).

${ }^{209}$ Robert J. Beck analisa as respostas que estudiosos do direito e das relações internacionais propõem a uma série de perguntas para investigar as relações entre as regras internacionais concernentes aos dois campos de conhecimento. Dentre essas questões, o autor inclui uma que o presente estudo considera ser, aqui, especialmente relevante: por que os atores observam as regras internacionais? O autor estabelece um diálogo entre diferentes visões; o texto tende a centrar-se na questão da legitimidade. Desperta a atenção, em especial, o posicionamento de Thomas Frank - The Power of Legitimacy among Nations -, para quem a eficácia da regra depende da percepção de sua legitimidade (BECK, Robert J. International law and international relations: the prospects for interdisciplinary collaboration. In: BECK, Robert J.; AREND, Anthony Clark; LUGT, Robert D. Vander (Eds.). International rules - approaches from international law and international relations. New York: Oxford University Press, 1996. p. 11 e ss.).
} 
internacionais de conduta. A primeira é a de facilitar a atuação das próprias empresas multinacionais, criando condições mais homogêneas e definindo as regras do jogo em busca de maior segurança e previsibilidade. A segunda é de construir um mecanismo de atuação responsável das empresas - ainda com base em elementos éticos, mas fundada em interesses de consenso ${ }^{210}$. Esse segundo aspecto estabelece uma relação mais salutar entre as empresas e o meio em que atuam, mas também cria um ambiente de competição mais equilibrada e justa, que inclui não só as empresas multinacionais, mas também as empresas locais.

Cuida-se, portanto, de tratamento internacional homogêneo de assuntos que impactam diretamente os ordenamentos internos dos Estados - um tema que demanda cooperação e cujas normas têm fonte no âmbito do direito internacional público. As normas são geradas com natureza internacional, mas o seu ingresso no ordenamento interno pode ser encarado de forma muito particular.

A observação da prática do PCN, no Brasil, denota que o instrumento é dotado de grande efetividade e serve de maneira muito interessante ao diálogo entre a sociedade civil e as empresas multinacionais. O desrespeito a uma disposição ocasionará uma reclamação que provocará a aproximação das partes (empresa e associações civis, por exemplo) para a solução negociada. Do processo, resultará um relatório - que tem efeitos sobre a imagem da empresa: positivos ou negativos, conforme a postura por ela adotada.

${ }^{210}$ DELMAS-MARTY, Mireille. La refondation des pouvoirs - les forces imaginantes du droit (III), p. 153: “À elle seule, l'éthique d'entreprise ne peut garantir le rééquilibrage des pouvoirs. Si l'objectif est uniquement d'améliorer l'image des entreprises auprès du public (et d'abord des consommateurs), les mécanismes non contraignants de l'ethique se réduisent à un effet d'affichage, un simple álibi pour éviter le mise en cause des véritables responsabilités. Ainsi, le coloque organisé en France en septembre 2005 par le ministére des Affaires étrangères et le MEDEF, 'Le droits de l'homme, facteur de performance pour les entreprises à l'international', a pu apparaître comme 'contre-feu à des proposition plus contraignantes'. En somme, une nouvelle forme de ces codes de conduite qui ont pu être analysés comme la manifestation d'un droit autorégulé et réflexif.

Précisément parce qu'ils sont réflexif, ces codes pourraient intégrer, par référence aux droits de l'homme, des élément d'intérêt general, avec, il est vrai, une efficacité variable selon qu'ils sont élaborés sous l'égide de la Chambre de Commerce internationale ou en partenariat avec des instituitions internationales, comes l'OCDE.". Tradução livre: "Sozinha, a ética empresarial não pode garantir o reequilíbrio de poderes. Se o objetivo é apenas melhorar a imagem corporativa para o público (e primordialmente para os consumidores), os mecanismos não vinculativos da ética são reduzidos a um efeito de vídeo, um simples pretexto para evitar colocar em causa as responsabilidades reais. Assim, o Colóquio realizado na França em setembro de 2005 pelo Ministério dos Negócios Estrangeiros e do MEDEF, 'Os direitos humanos, fator de desempenho para empresas no exterior', era visto como um 'contrafogo para propostas mais rigorosas'. Em suma, uma nova forma de códigos de conduta que possa ser analisada como uma manifestação de um direito autorregulado e reflexivo.

Precisamente porque são reflexivos, esses códigos podem incorporar, por referência aos direitos humanos, os elementos de interesse, com, é verdade, uma eficácia verdadeira dado que são elaborados sob os auspícios da Câmara de Comércio Internacional (ICC) ou em parceria com instituições internacionais como a OCDE.” 
Resta, contudo, a pergunta: tem o Estado brasileiro legitimidade para agir como mediador (PCN) nesse tipo de processo? Lembre-se que o documento internacional não foi objeto de assinatura, apreciação pelo Congresso Nacional e ratificação - o que inviabilizaria a assunção de obrigações internacionais; mas o caso sob estudo tem algumas particularidades que, em certa medida, o tornam diferente. Não é evidenciado, nesse sentido, que haja inviabilidade do sistema por vício formal - sobretudo pela desnecessária legalidade estrita e específica sobre as normas e mecanismos, como já se avaliou anteriormente, neste trabalho.

Entretanto, há um elemento de especial legitimidade material; em outras palavras, a questão que cabe é se o PCN poderia ser implantado para promoção de normas de conduta não dotadas de legalidade, no âmbito da Administração Pública brasileira.

A iniciativa seria - como de fato é - compatível com os princípios da ordem constitucional, notadamente da ordem econômica; ademais, se harmonizaria com a ideia de que o planejamento estatal é indicativo para a iniciativa privada ${ }^{211}$. Alerte-se que a atuação é compatível com um bloco de legalidade mais amplo - que releva o conjunto de elementos normativos.

Em última instância, ressalte-se que outros mecanismos de atuação estatal, sem criação de efetiva obrigação legal, estão presentes no ordenamento, como é exemplo das Comissões de Ética, no Serviço Público Federal.

Como já firmado, a função do PCN não se reveste de supremacia típica da Administração Pública, pois, ao contrário, sua autoridade não decorre da soberania estatal ou de sua autoridade - tanto é assim que a formação do PCN não necessariamente deve ter estrutura em ente estatal e pode contar com outros integrantes, chegando a ser admitida a forma colegiada. E o respeito a seus atos não decorre dos atributos do ato administrativo unilateral - notadamente a imperatividade e a autoexecutoriedade -, mas de um elemento de consensualidade, animado por um espírito de cooperação e promoção de valores constitucionais. Não se pode dizer, nesse sentido, que se trata de uma atuação contrária aos interesses estatais ou democráticos, mas promotores deles.

Essa tese é corroborada pela participação de associações e sindicatos nos processos do PCN - inclusive no caso brasileiro -, demonstrando que o mecanismo é um meio de participação ativa da sociedade civil. Do lado das empresas, nota-se a preocupação

211 “Art. 174. Como agente normativo e regulador da atividade econômica, o Estado exercerá, na forma da lei, as funções de fiscalização, incentivo e planejamento, sendo este determinante para o setor público e indicativo para o setor privado." 
destas com o atendimento de padrões elevados de conduta, compatíveis com as Linhas Diretrizes; essa preocupação é compatível com um comportamento de atenção aos chamados do PCN. No caso da Reclamação $\mathrm{n}^{-0}$ 01/2006, já abordado, fica patente o interesse da empresa por demonstrar que, a despeito do tratamento em âmbito judicial do assunto levado ao PCN, a reclamada se esmerou em promover projetos sociais com vistas a reduzir possíveis impactos sociais negativos de suas atividades na localidade do conflito alegado.

Verifica-se, portanto, que os padrões de conduta decorrem de certo consenso, acordado perante a OCDE, úteis para o aprimoramento das relações entre as empresas multinacionais e as realidades estatais. E que as ações do Estado concernentes à promoção das Diretrizes por meio do PCN não têm relação direta com o poder estatal, mas com a legitimidade. Nesse contexto, a atuação administrativa do Estado na promoção dos valores enunciados pelas Diretrizes não implica a inovação na ordem jurídica, mas o aprimoramento dos meios de promoção dos valores já pertinentes ao sistema e carreados de forte consenso.

\subsection{Diretrizes: Efetividade vs. Autoridade}

Os Tratados de Vestfália são reconhecidos como importante marco no desenvolvimento do Direito Internacional, ao consolidar um valor que será relevante para qualquer reflexão nesta disciplina: o princípio da igualdade jurídica dos Estados ${ }^{212}$. Com esse paradigma, o direito internacional se consolida como um sistema caracterizado por soberania - em um conceito mais cerrado -, territorialidade, autonomia e, sobretudo, legalidade.

$\mathrm{Na}$ ordem internacional vestfaliana o voluntarismo determina que os tratados são a fonte verdadeira do direito internacional, mas não há sobreposição de poderes. Não se admite, sob essa ótica, a existência de um ente supraestatal, ou a prevalência de qualquer dos atores sobre os demais Estados. Não há, portanto, autoridade na sociedade internacional de Estados $^{213}$.

\footnotetext{
${ }^{212}$ ACCIOLY, Hildebrando; NASCIMENTO E SILVA; G. E. do; CASELLA, P. B. Manual de direito internacional público, 18. ed., p. 84.

${ }^{213}$ A esse respeito: FLOH, Fábio. Direito internacional contemporâneo: elementos para a configuração de um direito internacional na Ordem Internacional Neo-Vestfaliana. In: CASELLA, P. B. et al. (Orgs.). Direito
} 
De fato, os traços dessa ordem permanecem com grande intensidade, pela história, e ainda são encontrados na enunciação da Carta que cria a Sociedade das Nações. Nela, a afirmação de valores como a segurança e a autodeterminação prevalece. Em uma nova ordem, contudo, de pós-Segunda Guerra, a preocupação com a efetividade dos direitos de dignidade revela-se de forma crescente. No modelo onusiano, a segurança e a paz assumem mais o papel de meio do que de fim.

No cenário cooperativo, em que se inserem as Diretrizes, a efetividade dos direitos é que ganha relevância, legando os parâmetros voluntaristas à função instrumental. Trata não de negá-la por alguma meio, mas de admitir que as formalidades voluntaristas não constituem fim, mas meio para a promoção de valores ligados aos direitos e à dignidade humana.

Com efeito, Michel Villey criticava ${ }^{214}$ a exacerbada idolatria da lei, em desprestígio de outras fontes igualmente importantes de revelação do direito. Os costumes, a jurisprudência, a produção intelectual dos pensadores do direito são materiais tão legítimos quanto a produção legislativa.

As Diretrizes, sem negar as formalidades que acompanham o direito internacional, têm o mérito de reunir de forma voluntariosa - e não voluntarista - atores envolvidos em atividades empresariais, em atuação que supera fronteiras territoriais. Nesse contexto, a função estatal de promover o respeito a direitos será mais bem desempenhada de forma cooperativa, sob o prisma da efetividade, e não exclusivamente da autoridade.

Do ponto de vista da ordem interna dos Estados, as mesmas ideias se aplicam; no entanto, o elemento da autoridade é marcante nos sistemas estatais e pode se ver aqui superado, de uma perspectiva radical, pela aplicação dos mesmos princípios. O princípio da cooperação e a compreensão da soberania como um instrumental de efetivação de direito nos induz a admitir formas de promoção desses direitos, que não necessariamente um modo estrito, atrelado à atuação coercitiva e sancionatória por mecanismos oficiais.

internacional, humanismo e globalidade - amicorum discipulorum liber: homenagem a Guido Fernando Silva Soares, p. 219.

${ }^{214}$ VILLEY, Michel. Archives de Philosophie du Droit. Paris: Sirey, 1959, p. 65: "Et du sommet qu'on a choisi, tout lê paysage. A nous restituer une milleure théorie dês sources, qui nous libere de l'idolâtrie de la loi. A rendre un sens à l'expression de droit naturel, dont autrement nous avons fait une notion impraticable. A mieux apprécier la présence de la doctrine, de la costume, des précédents de jurisprudence, parmi lês source autonomes de la connaissance du droit, sans être contraint de recourir à dês fictions encombrantes.”. 


\section{CONCLUSÃO}

O presente trabalho se propôs a analisar a implementação, no Brasil, das Linhas Diretrizes da OCDE para as Empresas Multinacionais, documento que integra a Declaração sobre o Investimento Internacional e as Empresas Multinacionais.

O estudo mostrou que o direito brasileiro tem um desafio de renovação, diante da necessidade de compreensão de que muitas formas de relações são possíveis e úteis, no contexto internacional. A limitação da percepção do direito internacional como um sistema clássico em que as fontes são unicamente aquelas descritas no artigo 38 do Estatuto da Corte Internacional de Justiça deve ser superada inclusive no âmbito do direito interno. $\mathrm{O}$ tratamento das relações entre o direito internacional e o direito interno não pode resumir-se - ou mesmo centrar-se - na recepção de tratados e discussão sobre as teorias monista, dualista e suas variações.

A implementação das Linhas Diretrizes para Empresas Multinacionais evidencia a situação. Há necessidade de compreensão da ordem jurídica interna como uma ordem vocacionada à cooperação e, fundado nisso, deve-se refletir sobre as possibilidades de integração das ordens interna e internacional, notadamente no contexto dos atos de organizações internacionais.

As organizações internacionais - notadamente a OCDE - podem ser encaradas de vários pontos de vista; mas é certo que cumprem papel de destaque na produção normativa e cooperativa. Sabe-se que as organizações internacionais não constituem o único meio pelo qual o direito internacional moderno possa se desenvolver e se efetivar, mas é certo que promovem encontros e criam condições muito favoráveis para esse processo normativo e cooperativo.

No caso das Linhas Diretrizes para Empresas Multinacionais, o fato de ser gerida na OCDE é, sem dúvida, determinante para a sua sorte. Essa organização foi conformada historicamente como uma instância de consenso entre os membros, sempre construído apoiado em um conjunto de informações técnicas produzidas pela própria OCDE com a colaboração de seus membros. A pesquisa constitui, sem dúvida, um diferencial. É inegável, portanto, que a legitimidade comumente identificada nas decisões e atos da OCDE tem profundas raízes nos seus mecanismos de funcionamento e de decisões - resultado de um processo histórico relevante. 
O conteúdo das Linhas Diretrizes, ademais, é um consenso estatal não só entre os membros da OCDE, pois, sem sombra de dúvida, seu conteúdo expressa valores aceitos pelas empresas, bem como pelas entidades da sociedade civil. A observância das relações estabelecidas no ainda incipiente - mas ativo - Ponto de Contato Nacional (PCN) brasileiro permite esse tipo de conclusão. De fato, as entidades da sociedade civil procuram socorrer-se desse foro de resolução de controvérsias, enquanto as empresas dispensam uma postura de respeito e atenção ao procedimento do PCN.

Reitere-se, ainda, o seguinte ponto levantado neste estudo: as Linhas Diretrizes reúnem muitas características que resultam em um contexto de eficácia quase inesperado. Em primeiro lugar, constituem um código de conduta decorrente de consenso - tanto o consenso estatal como o consenso dos particulares envolvidos (até porque é improvável que os interesses das grandes companhias multinacionais não sejam bem representados na OCDE). A esse propósito, há, para as empresas multinacionais, um conteúdo útil ao desenvolvimento de suas atividades e à segurança de seus investimentos, pautado em uma série de compromissos não obrigatórios do ponto de vista legal. A despeito de não serem obrigatórios, esses compromissos conformam uma espécie de direito autorregulatório e de produção reflexiva que, no extremo, não fazem mais do que induzir as empresas a zelar por um alto grau de respeito às ordens jurídicas internas e a estabelecer diálogo ante os conflitos suscitados. São, portanto, normas de alto grau de legitimidade.

Mesmo assim, não seria eficiente confiar a efetividade de um conjunto normativo tão somente a pressupostos éticos ou meramente espontâneos. A utilidade desses padrões de conduta seria intensamente reduzido, se não houvesse o mecanismo do PCN - instrumento que eleva a utilidade das Linhas Diretrizes, por instituir um foro de aproximação de opostos, e que produz motivação para o diálogo, ao criar um método de pressão social e de pressão dos pares.

A sistemática de atuação da OCDE sempre esteve pautada pela adoção de mecanismos que privilegiassem a cobrança das posturas acordadas pelos próprios pares no seio da organização. Essa sistemática contaminou o mecanismo de promoção das Linhas Diretrizes, em especial pela implantação dos PCNs, os quais, como já se viu, servem de instância de promoção das Linhas Diretrizes, notadamente pelo trabalho de fiscalização do cumprimento dos compromissos, por atores privados. Serve, nesse sentido, como meio de solução de conflitos ou de pressão - pela publicação de relatórios sobre os casos que lhes são submetidos a apreciação. 
Há uma racionalidade evidente no sistema; mas será que esse sistema é compatível com a ordem jurídica brasileira?

Não se nota evidência de incompatibilidade. A adesão do Brasil como não membro, à Declaração que contém as Linhas Diretrizes, e o desenvolvimento das atividades do PCN brasileiro não mostram indícios de incompatibilidade material; ao contrário, o sistema demonstra contribuir intensamente para a realização do interesse público e dos valores constitucionais, por um mecanismo diferenciado.

Em outras palavras, a implementação das Linhas Diretrizes no Brasil só é viável - do ponto de vista jurídico - se os pressupostos de relacionamento entre o direito interno e o direito internacional forem retomados sob uma ótica mais ampla do que a comumente admitida pela literalidade do sistema normativo brasileiro.

É imperativo admitir que as relações - especialmente além fronteiras desenvolveram-se e influenciaram a realidade do direito internacional. Esse direito internacional - moderno - distancia-se do clássico, porque é mais plural em suas formas. Trata-se de um direito que procura atender às necessidades de um mundo em que as relações são intensas e no qual a soberania só tem sentido se compreendida como o poder que os Estados têm para promover os direitos.

A soberania não pode mais ser encarada como a afirmação individual do poder e da autonomia estatal, por si só. Ela deve se inserir no contexto dessa nova realidade, na qual não se pode admitir que os limites soberanos sirvam de álibi para aqueles que pretendam agir em desacordo com o direito dos Estados e aceito pelos Estados. A soberania, portanto, deve harmonizar-se com uma visão de Estado cooperativo, pronto a atuar em conjunto com seus pares a bem da promoção de valores admitidos internacionalmente.

Importa destacar que esse é o contexto do Estado cooperativo - e a cooperação internacional é um valor presente na ordem constitucional brasileira, seja pela recepção da Carta da ONU, fundada sobre esse valor, seja por decorrência direta do texto constitucional brasileiro.

Um Estado que pretende intensificar sua participação na ordem internacional com maturidade deve desenvolver seu direito de modo a permitir que essa participação se dê de forma plena, mas organizada. Daí a necessidade de compreender que, além das mudanças nos paradigmas do Direito Constitucional e Administrativo, as relações entre o direito interno e o direito internacional não podem limitar-se tão somente à obediência de um iter procedimental que passe cega e necessariamente pelo artigo 49, inciso I, da 
Constituição Federal. Se, por um lado, a ordem jurídica brasileira admite interpretações como a proposta por este trabalho - fundada em princípios constitucionais, notadamente o cooperativo -, por outro, em face da cultura jurídica brasileira, o sistema se beneficiaria com maior desenvolvimento de dispositivos sobre a integração do direito internacional, com o cuidado de prevenir a desordem e a captura dos interesses nacionais.

Infere-se, portanto, que o direito brasileiro se mostra constitucionalmente receptivo e plástico diante das crescentes necessidades de sua integração à ordem internacional; mas, em face da incessante intensificação dessas relações, o sistema se beneficiará de maior desenvolvimento normativo. 


\section{REFERÊNCIAS}

ACCIOLY, Hildebrando; NASCIMENTO E SILVA, G. E. do; CASELLA, P. B. (Orgs.). Manual de direito internacional público. 16. ed. São Paulo: Saraiva, 2008.

18. ed. São Paulo: Saraiva, 2010.

ALVAREZ, José E. International organizations as law-makers. New York: Oxford University Press, 2006.

ARAÚJO, N. A importância da cooperação jurídica internacional para a atuação do Estado brasileiro no plano interno e internacional. In: DEPARTAMENTO DE RECUPERAÇÃO DE ATIVOS E COOPERAÇÃO JURÍDICA INTERNACIONAL - DRCI. Manual de cooperação jurídica internacional e recuperação de ativos - matéria civil. Brasília: Secretaria Nacional de Justiça, Ministério da Justiça, 2008.

BARBOSA, Rubens. O Brasil e a OCDE. O Estado de S. Paulo, 27 dez. 2005. Disponível em: <www.eagora.org.br/arquivo/O-Brasil-e-a-OCDE>. Acesso em: 17 mar. 2011.

BECK, Robert J. International law and international relations: the prospects for interdisciplinary collaboration. In: BECK, Robert J.; ARENDT, Anthony Clark; LUGT, Robert D. Vander (Eds.). International rules - approaches from international law and international relations. New York: Oxford University Press, 1996.

BETTATI, Mario. Création et personnalité juridique des organisations internationales. In: DUPUY, René Jean (Ed.). Manuel sur les organizations internationales. The Hague Academy of International Law Hage (Des Cours - Colloques, 87). Dordrecht: Martinus Nijhoff Publishers, 1998.

BITTERMANN, Henry J. Negotiation of the articles of agreement of the International Bank for Reconstruction and Development. International Lawyers, v. 5, n. 1, 1979.

BOBBIO, Norberto. A era dos direitos. Rio de Janeiro: Campus, 1992.

BODANSKY, Daniel. The legitimacy of international governance: a coming challenge for international environmental law? The American Journal of International Law, v. 93, n. 3, p. 596-624, Jul. 1999. 
BRASIL. Supremo Tribunal Federal. AC 2.436, Rel. Min. Gilmar Mendes, julgamento em 03-09-2009.

. ADC 12, relatoria Ministro Carlos A. Brito, julgamento em 20.08.2008.

MC-ADI 1.480-3 DF, Rel. Min. Celso de Mello, julgamento 04.09.1997.

. Pet 4625, relatoria Min. Ellen Gracie, julgamento em 09.07.2009. Voto do Ministro Celso de Mello.

BRUSSE, Wendy Asbeek; GRIFFITHS, Richard T. Exploring the OEEC's past: the potentials and the sources. In: GRIFFITHS, Richard T. (Ed.). Explorations in OEEC history, OECD historical series. Paris: OECD, 1997.

CAHIER, Philippe. L'ordre juridique interne des organisations internationales. In: DUPUY, René Jean (Ed.). Manuel sur les organizations internationales. The Hague Academy of International Law Hage (Des Cours - Colloques, 87). Dordrecht: Martinus Nijhoff Publishers, 1998.

CAMPOS, João Mota de et al. Teoria geral das organizações internacionais. Lisboa: Fundação Calouste Gulbenkian, 1999.

CASELLA, P. B. et al. (Orgs.). Direito internacional, humanismo e globalidade amicorum discipulorum liber: homenagem a Guido Fernando Silva Soares. São Paulo: Atlas, 2008.

CASSESE, Antonio. International law. 2th ed. New York: Oxford University Press, 2005.

CELLI JUNIOR, U. Teoria geral da integração: em busca de um modelo alternativo. In: MERCADANTE, A. A.; CELLI JUNIOR, U.; ARAÚJO, L. R. (Orgs.). Blocos econômicos e integração na América Latina, África e Ásia. Curitiba: Juruá, 2008. v. 1.

CHIU, H. "Succession in International Organizations", international and comparative law. Quarterly, v. 14, p. 83-120, 1965.

COMPARATO, Fábio Konder. A humanidade no século XXI: a grande opção conferência pronunciada na Faculdade de Direito da Universidade de Coimbra, em 16 fev. 2000. Disponível em: <http://www.hottopos.com/convenit2/compara.htm>. Acesso em: 4 out. 2006. 
CONCISE Oxford American Dictionary. New York: Oxford University Press, 2006.

DALLARI, P. B. de Abreu. Atualidade da Declaração Universal dos Direitos Humanos. Política Externa, USP, v. 17, p. 55-65, 2008.

Atualidades dos tribunais administrativos de organizações internacionais.

Trabalho (Livre-Docência) - Universidade de São Paulo - USP, São Paulo, 2009.

Constituição e tratados internacionais. São Paulo: Saraiva, 2003.

Princípios de relações exteriores na Constituição brasileira de 1988. 1992. Dissertação (Mestrado) - Faculdade de Direito da Universidade de São Paulo - FDUSP, São Paulo, 1992.

Constituição e relações exteriores. São Paulo: Saraiva, 1994.

DELMAS-MARTY, Mireille. La refondation des pouvoirs - les forces imaginantes du droit (III). Paris: Le Seuil, 2007.

DI PIETRO, Maria Sylvia Zanella. Direito administrativo. 20. ed. São Paulo: Atlas, 2007.

DUPUY, René-Jean. Manuel sur les organizations internationales. The Hage Academy. Dordrecht: Martinus Nijhoff Publishers, 1998.

FLOH, Fábio. Direito internacional contemporâneo: elementos para a configuração de um direito internacional na Ordem Internacional Neo-Vestfaliana. In: CASELLA, P. B. et al. (Orgs.). Direito internacional, humanismo e globalidade - amicorum discipulorum liber: homenagem a Guido Fernando Silva Soares. São Paulo: Atlas, 2008.

HÄBERLE, Peter. Estado constitucional cooperativo. São Paulo: Renovar, 2007.

HEILBRONER, Robert. L. A formação da sociedade econômica. 5. ed. Rio de Janeiro: Guanabara, 1980.

HESSE, Konrad. A força normativa da Constituição. Porto Alegre: Fabris, 1991.

HOBSBAWN, E. A era dos extremos: o breve século XX (1914-1991). São Paulo: Cia. das Letras, 1995. 
KISSINGER, H. Diplomacy. 3. ed. Rio de Janeiro: Livraria Francisco Alves, 2001.

LAFER, Celso. Comércio e relações internacionais. São Paulo: Perspectiva, 1977, p. 26. In: PERRONE-MOISÉS, Cláudia. O código de conduta da ONU para as empresas multinacionais - instrumento jurídico de regulamentação das relações econômicas internacionais. 1991. Dissertação (Mestrado) - Departamento de Direito Internacional da Faculdade de Direito da Universidade de São Paulo - FDUSP, São Paulo, 1991.

MARTINS, Margarida S. d'Oliveira; MARTINS, Afonso d'Oliveira. Direito das Organizações Internacionais. 2. ed. Lisboa: Associação da Faculdade de Direito de Lisboa, 1996. v. I.

MENEZES, Wagner. Mercado Comum do Sul (Mercosul). In: MERCADANTE, A. A.; CELLI JUNIOR, U.; ARAÚJO, Leandro Rocha (Orgs.). Blocos econômicos e integração na América Latina, África e Ásia. Curitiba: Juruá, 2008. v. 1.

MUCHLINSKI, Peter T. Multinational enterprises and the law. 2th ed. New York: Oxford University Press, 2007.

NASSER, Salem H. Fontes e normas do direito internacional: um estudo sobre a Soft Law. 2. ed. São Paulo: Atlas, 2006.

PERRONE-MOISÉS, Cláudia. O código de conduta da ONU para as empresas multinacionais - instrumento jurídico de regulamentação das relações econômicas internacionais. 1991. Dissertação (Mestrado) - Departamento de Direito Internacional da Faculdade de Direito da Universidade de São Paulo - FDUSP, São Paulo, 1991.

PINTO, Denis Fontes de Souza. OCDE: uma visão brasileira. Brasília: IRBR, 2000.

QUOC DINH, Nguyen; DAILlIER, Patrick; PELLET, Alain. Direito internacional público. 2. ed. Lisboa: Fundação Calouste Gulbenkian, 2003.

RAMOS, André de Carvalho. A execução das sentenças da Corte Interamericana de Direitos Humanos no Brasil. In: CASELLA, P. B. et al. (Orgs.). Direito internacional, humanismo e globalidade - amicorum discipulorum liber: homenagem a Guido Fernando Silva Soares. São Paulo: Atlas, 2008.

ROMERO, Cristiano. Brasil resiste a aderir ao "clube dos ricos". Valor Econômico, 22 jun. 2009, p. A14. 
SAROOSHI, Dan. International organizations and their exercise of sovereign powers. New York: Oxford University Press, 2005.

SCHIRATO, Vitor Rhein; PALMA, Bonacorsi de. Conseno e legalidade: vinculação da atividade administrativa consensual ao direito. Revista Eletrônica sobre Reforma do Estado, n. 24, dez./jan./fev. 2011.

SILVA, José Afonso da. Curso de direito constitucional positivo. 28. ed. São Paulo: Malheiros, 2007.

Curso de direito constitucional positivo. 16. ed. São Paulo: Malheiros, 1998.

SLAUGHTER, Anne Marie. Sovereignty and power in a networked world order. Stanford Journal of International Law, n. 40, p. 283-327, 2004.

TRU, Nguyen Huu. Les codes de conduite, un bilan. Revue General de Droit International Public, p. 45-60, 1992.

VILLEY, Michel. Archives de Philosophie du Droit. Paris: Sirey, 1959.

WHITE, N. D. The law of international organizations. Manchester: Manchester University Press, 1996.

YEARBOOK of the International Law Comission, 1966. v. II.

ZEMANEK, Karl. General course on public international law, R.C.A.D.I., 1997-1998. t. 266.

The legal foundations of the international system: general course on public international law. Recueil des Cours, v. 266, p. 88-90, 1997.

\section{Outros documentos}

BRASIL. Câmara dos Deputados. Diário da Câmara dos Deputados. Sábado, 12 out. 1996, p. 26.564.

PCN. Relatório Final da Reclamação n. 01/2006. 


\section{Principais documentos da OCDE}

OCDE - OECD. Resolution of the Council concerning the participation of non-members in the work of subsidiary bodies of the Organization (C(2004)132/FINAL).

\begin{tabular}{c} 
Council Resolution on enlargement and enhanced engagement \\
\hline C/MIN(2007)4/FINAL.
\end{tabular} . Resolution of the Council on the Terms of Reference of the Investment Committee [C(2008)169 and C/M(2008)20, item 286, ii].

. Annual Report on the OECD Guidelines for Multinational Enterprises 2010 Corporate Responsibility: Reinforcing a Unique Instrument, Structure of National Contact Points.

. Revised Resolution Of The Council On A New Governance Tructure For The Organisation. C(2006)78/REVI/FINAL.

The OECD Guidelines for Multinational Enterprises. Revision 2000.

Decision of the Council on Conflicting Requirements being imposed on Multinational Enterprises. 5 June 1991 - C(91)73.

Decision of the Council on the OECD Guidelines for Multinational

Enterprises. 27 June 2000 - C(2000)96/FINAL Amended on 25 May 2011 C/MIN(2011)11.

. Working Party of the Investment Committee. Extract from document DAF/INV/WD(2008)11.

Síntese - Linhas Diretrizes da OCDE para as Empresas Multinacionais. Tradução para o português. Overview - OECD Guidelines for Multinational Enterprises Portuguese translation. Disponível em: <www.oecd.org/bookshop/>. Acesso em: jun. 2000.

Report by the Chair of the 2010 Annual Meeting of NCPS. Annual Meeting of the National Contact Points for the OECD Guidelines for Multinational Enterprises. DAF/INV/NCP(2010)1/REV1. 


\section{Sítios eletrônicos}

http://www.oecd.org

http://www.fazenda.gov.br

http://www.senado.gov.br

http://www.planalto.gov.br

http://www.stf.jus.br

http://webnet.oecd.org

http://ictsd.org

www.eagora.org.br 
ANEXOS 


\title{
OCDE - Organização de Cooperação e Desenvolvimento Econômico
}

\author{
O Secretário-Geral
}

DJJ/97. 504

14 de novembro de 1997

\author{
Prezado Senhor Embaixador,
}

Em nome dos Governos dos Países-Membros da OCDE, tenho a honra de convidar o Brasil a aderir, com os mesmos direitos e responsabilidades dos demais Países-Membros da OCDE, à Declaração sobre Investimentos Internacionais e Empresas Multinacionais (doravante denominada "a Declaração") de 21 de junho de 1976 [C(76)99(Final), na versão emendada]. A Declaração foi anexada à presente Nota para sua consideração.

Em conformidade com uma decisão do Conselho da OCDE, fui solicitado, também, a convidar o Brasil a, juntamente com sua adesão à Declaração, tomar as seguintes medidas:

i) aderir, com os mesmos direitos e responsabilidades dos demais Países-Membros da OCDE no âmbito das mesmas:
- às Recomendações relacionadas do Conselho, [C(86)55 (Final), C(87)76(Final), C(88)41(Final), C (88) 131 (Final)e [C(89)76(Final)], e
- às Decisões procedimentais relacionadas do Conselho, [C(84)90, na versão emendada, C(84)92, C(91)73 e C(91) 147/FINAL, na versão emendada], sujeitas à notificação de exceções ao Instrumento de Tratamento Nacional, não mais extensivas que as relacionadas no Anexo 1 da Nota C(97) 198;

ii) tornar-se um observador regular junto ao Comitê para Investimentos Internacionais e Empresas Multinacionais (CIME) e de seus Grupos de Trabalho e cooperar com suas atividades, desde que continue parte da Declaração e das Decisões e Recomendações relacionadas do Conselho, na forma em que venham a ser complementadas ou emendadas ocasionalmente. 
- CIME desenvolve suas atividades com base nas disposições aplicáveis da Convenção da Organização de Cooperação e Desenvolvimento Econômico e da Resolução do Conselho [C(84)171(FINAL)]. Os Grupos de Trabalho do CIME desenvolvem suas atividades com base nos termos de referência definidos pelo CIME.

Por último, o Conselho convida o Brasil:

(a) a aderir à Recomendação Revisada do Conselho de 23 de maio de 1997 sobre o Combate ao Suborno em Transações Comerciais Internacionais [C(97)123/ FINAL] e à Recomendação do Conselho de 11 de abril de 1996 sobre a Dedutibilidade Fiscal de Subornos a Funcionários Públicos Estrangeiros [C(96)27/FINAL], na forma em que venham a ser complementadas ou emendadas ocasionalmente, e

(b) a se tornar pleno participante do Grupo de Trabalho da OCDE para Subornos em Transações Comerciais Internacionais, com os mesmos direitos e responsabilidades dos Membros da OCDE, desde que sua adesão aos Atos relacionados do Conselho seja mantida.

As condições para a participação do Brasil no CIME e em seus Grupos de Trabalho, inclusive no Grupo de Trabalho para Subornos em Transações Comerciais Internacionais, serão regidas pelas normas, procedimentos e diretrizes estabelecidos pelo Conselho, particularmente os indicados na [C(96)64REV1/FINAL], na forma em que venham a ser modificados ocasionalmente.

As contribuições do Brasil, como observador junto ao CIME e pleno participante do Grupo de Trabalho para Subornos em Transações Comerciais Internacionais, serão estabelecidas em conformidade com os termos e condições previstos na Resolução do Conselho sobre taxas para países observadores regulares e plenos participantes não-membros dos organismos subsidiários da OCDE [C(96)223/FINAL], na forma em que venham a ser modificados ocasionalmente.

os diversos Atos do Conselho mencionados na presente Nota foram anexados à mesma.

Proponho que a presente Nota e a resposta afirmativa de seu Governo à mesma constituam um acordo entre a Organização e o Governo do Brasil, mediante o qual - Brasil aceita o convite descrito acima e os direitos e obrigações a ele relacionados. O presente acordo entrará em vigor na data da notificação de seu Governo à Organização sobre a conclusão dos procedimentos constitucionais necessários e poderá ser denunciado por qualquer das partes 
mediante notificação por escrito com seis meses de antecedência

Atenciosamente,

Donald J. Johnston 
Paris, 14 de novembro de 1997

Prezado Secretário-Geral,

Tenho a honra de acusar o recebimento de sua Nota de hoje, que diz o seguinte:

"Em nome dos Governos dos Países Membros da OCDE, tenho a honra de convidar o Brasil a aderir, com os mesmos direitos e responsabilidades dos demais Países-Membros da OCDE, à Declaração sobre Investimentos Internacionais e Empresas Multinacionais (doravante denominada "a Declaração") de 21 de junho de 1976 [C(76)99(FINAL), na versão emendada]. A Declaração foi anexada à presente Nota para sua consideração.

Em conformidade com uma decisão do Conselho da OCDE, fui solicitado, também, a convidar o Brasil a, juntamente com sua adesão à declaração, tomar as seguintes medidas:

i) aderir, com os mesmos direitos e responsabilidades dos demais Países-Membros da OCDE no âmbito das mesmas:

- às Recomendações relacionadas do Conselho, [C(86)55 (Final), C(87)76(Final), $\quad \mathrm{C}(88) 41$ (Final), $\quad \mathrm{C}(88) 131$ (Final) e [C(89)76(Final)], e

- às Decisões procedimentais relacionadas do Conselho, [C(84)90, na versão emendada, C(84)92, C(91)73 e C(91)147/FINAL, na versão emendada], sujeitas à notificação de exceções ao lnstrumento de Tratamento Nacional, não mais extensivas que as relacionadas no Anexo 1 da Nota C(97)198;

ii) tornar-se um observador regular junto ao Comitê para Investimentos Internacionais e Empresas Multinacionais (CIME) e de seus Grupos de Trabalho e cooperar com suas atividades, desde que continue parte da Declaração e das Decisões e Recomendações relacionadas do Conselho, na forma em que venham a ser complementadas ou emendadas ocasionalmente.

O CIME desenvolve suas atividades com base nas disposições aplicáveis da Convenção da Organização de Cooperação e Desenvolvimento Econômico e da Resolução do Conselho [C(84)171(FINAL)]. Os Grupos de Trabalho do CIME desenvolvem suas atividades com base nos termos de referência definidos pelo CIME. 
Por último, o Conselho convida o Brasil:

a) a aderir à Recomendação Revisada do Conselho de 23 de maio de 1997 sobre o Combate ao Suborno em Transações Comerciais Internacionais [C(97)123/FINAL] e à Recomendação do Conselho de 11 de abril de 1996 sobre a Dedutibilidade Fiscal de Subornos a Funcionários Públicos Estrangeiros [C(96)27/FINAL], na forma em que venham a ser complementadas ou emendadas ocasionalmente, e

b) a se tornar pleno participante do Grupo de Trabalho da OCDE para Subornos em Transações Comerciais Internacionais, com os mesmos direitos e responsabilidades dos Membros da OCDE, desde que sua adesão aos Atos relacionados do Conselho seja mantida.

As condições para a participação do Brasil no CIME e em seus Grupos de Trabalho, inclusive no Grupo de Trabalho para Subornos em Transações Comerciais Internacionais, serão regidas pelas normas, procedimentos e diretrizes estabelecidos pelo Conselho, particularmente os indicados na [C(96)64REV1/FINAL], na forma em que venham a ser modificados ocasionalmente.

As contribuições do Brasil, como observador junto ao CIME e pleno participante do Grupo de Trabalho para Subornos em Transações Comerciais Internacionais, serão estabelecidas em conformidade com os termos e condições previstos na Resolução do Conselho sobre taxas para países observadores regulares e plenos participantes não-membros dos organismos subsidiários da OCDE [C(96)223/FINAL], na forma em que venham a ser modificados ocasionalmente.

Os diversos Atos do Conselho mencionados na presente Nota foram anexados à mesma.

Proponho que a presente Nota e a resposta afirmativa de seu Governo à mesma constituam um acordo entre a Organização e o Governo do Brasil, mediante o qual o Brasil aceita o convite descrito acima e os direitos e obrigações a ele relacionados. O presente acordo entrará em vigor na data da notificação de seu Governo à Organização sobre a conclusão dos procedimentos constitucionais necessários e poderá ser denunciado por qualquer das partes mediante notificação por escrito com seis meses de antecedência".

Tenho o prazer de informá-lo que a Nota acima tem a aprovação do meu Governo. Como previsto na mesma, sua Nota e a presente resposta constituem um acordo entre o Governo do Brasil e a Organização de Cooperação e Desenvolvimento Econômico que entrará em vigor na data de nossa notificação à OCDE sobre a conclusão de nossos procedimentos constitucionais. 
Queira aceitar, Senhor, os protestos de minha mais elevada consideração.

\section{Marcos Castrioto de Azambuja \\ Embaixador}

Senhor Donald Johnston

Secretário-Geral OCDE 


\title{
Declaration on International Investment and Multinational Enterprises
} OECD

\author{
21 June 1976 - C(76)99/FINAL \\ Amended on \\ 13 June 1979 - C(79)102/FINAL \\ 17 May 1984 - C/MIN(84)6(FINAL) \\ 5 June $1991-C / M I N(91) 7$ \\ 27 June 2000 - C(2000)96/FINAL \\ 25 May 2011 - C/MIN(2011)11/FINAL
}

\section{ADHERING GOVERNMENTS ${ }^{[1]}$ \\ CONSIDERING:}

- That international investment is of major importance to the world economy, and has considerably contributed to the development of their countries

- That multinational enterprises play an important role in this investment process;

- That international co-operation can improve the foreign investment climate, encourage the positive contribution which multinational enterprises can make to economic, social and environmental progress, and minimise and resolve difficulties which may arise from their operations;

- That the benefits of international co-operation are enhanced by addressing issues relating to international investment and multinational enterprises through a balanced framework of inter-related instruments;

\section{DECLARE:}

\section{Guidelines for Multinational Enterprises}

I. That they jointly recommend to multinational enterprises operating in or from their territories the observance of the Guidelines, set forth in Annex 1 hereto, having regard to the considerations and understandings that are set out in the Preface and are an integral part of them;

\section{National Treatment}

II.1. That adhering governments should, consistent with their needs to maintain public order, to protect their essential security interests and to fulfil commitments relating to international peace and security, accord to enterprises operating in their territories and owned or controlled directly or indirectly by nationals of another adhering government (hereinafter referred to as ("ForeignControlled Enterprises") treatment under their laws, regulations and administrative practices, consistent with international law and no less favourable than that accorded in like situations to domestic enterprises (hereinafter referred to as "National Treatment");

2. That adhering governments will consider applying "National Treatment" in respect of countries other than adhering governments;

3. That adhering governments will endeavour to ensure that their territorial subdivisions apply "National Treatment"

4. That this Declaration does not deal with the right of adhering governments to regulate the entry of foreign investment or the conditions of establishment of foreign enterprises;

\section{Conflicting Requirements}

III. That they will co-operate with a view to avoiding or minimising the imposition of conflicting requirements on multinational enterprises and that they will take into account the general considerations and practical approaches as set forth in Annex 2 hereto.

\section{International Investment Incentives and Disincentives}

IV.1 That they recognise the need to strengthen their co-operation in the field of international direct investment;

2. That they thus recognise the need to give due weight to the interests of adhering governments affected by specific laws, regulations and administrative practices in this field (hereinafter called "measures") providing official incentives and disincentives to international direct investment;

3. That adhering governments will endeavour to make such measures as transparent as possible, so that their importance and purpose can be ascertained and that information on them can be readily available;

\section{Consultation Procedures}

V. That they are prepared to consult one another on the above matters in conformity with the relevant Decisions of the Council; Review

VI. That they will review the above matters periodically with a view to improving the effectiveness of international economic cooperation among adhering governments on issues relating to international investment and multinational enterprises. 


\section{ANNEX 1 \\ $-$}

GUIDELINES FOR MULTINATIONAL ENTERPRISES:

\section{RECOMMENDATIONS FOR RESPONSIBLE BUSINESS CONDUCT IN A GLOBAL CONTEXT}

\section{Preface}

1. The OECD Guidelines for Multinational Enterprises (the Guidelines) are recommendations addressed by governments to multinational enterprises. The Guidelines aim to ensure that the operations of these enterprises are in harmony with government policies, to strengthen the basis of mutual confidence between enterprises and the societies in which they operate, to help improve the foreign investment climate and to enhance the contribution to sustainable development made by multinational enterprises. The Guidelines are part of the OECD Declaration on International Investment and Multinational Enterprises the other elements of which relate to national treatment, conflicting requirements on enterprises, and international investment incentives and disincentives. The Guidelines provide voluntary principles and standards for responsible business conduct consistent with applicable laws and internationally recognised standards. However, the countries adhering to the Guidelines make a binding commitment to implement them in accordance with the Decision of the OECD Council on the OECD Guidelines for Multinational Enterprises. Furthermore, matters covered by the Guidelines may also be the subject of national law and international commitments.

2. International business has experienced far-reaching structural change and the Guidelines themselves have evolved to reflect these changes. With the rise of service and knowledge-intensive industries and the expansion of the Internet economy, service and technology enterprises are playing an increasingly important role in the international marketplace. Large enterprises still account for a major share of international investment, and there is a trend toward large-scale international mergers. At the same time, foreign investment by small- and medium-sized enterprises has also increased and these enterprises now play a significant role on the international scene. Multinational enterprises, like their domestic counterparts, have evolved to encompass a broader range of business arrangements and organisational forms. Strategic alliances and closer relations with suppliers and contractors tend to blur the boundaries of the enterprise.

3. The rapid evolution in the structure of multinational enterprises is also reflected in their operations in the developing world, where foreign direct investment has grown rapidly. In developing countries, multinational enterprises have diversified beyond primary production and extractive industries into manufacturing, assembly, domestic market development and services. Another key development is the emergence of multinational enterprises based in developing countries as major international investors.

4. The activities of multinational enterprises, through international trade and investment, have strengthened and deepened the ties that join the countries and regions of the world. These activities bring substantial benefits to home and host countries. These benefits accrue when multinational enterprises supply the products and services that consumers want to buy at competitive prices and when they provide fair returns to suppliers of capital. Their trade and investment activities contribute to the efficient use of capital, technology and human and natural resources. They facilitate the transfer of technology among the regions of the world and the development of technologies that reflect local conditions. Through both formal training and on-the-job learning enterprises also promote the development of human capital and creating employment opportunities in host countries.

5. The nature, scope and speed of economic changes have presented new strategic challenges for enterprises and their stakeholders. Multinational enterprises have the opportunity to implement best practice policies for sustainable development that seek to ensure coherence between economic, environmental and social objectives. The ability of multinational enterprises to promote sustainable development is greatly enhanced when trade and investment are conducted in a context of open, competitive and appropriately regulated markets.

6. Many multinational enterprises have demonstrated that respect for high standards of business conduct can enhance growth. Today's competitive forces are intense and multinational enterprises face a variety of legal, social and regulatory settings. In this context, some enterprises may be tempted to neglect appropriate principles and standards of conduct in an attempt to gain undue competitive advantage. Such practices by the few may call into question the reputation of the many and may give rise to public concerns.

7. Many enterprises have responded to these public concerns by developing internal programmes, guidance and management systems that underpin their commitment to good corporate citizenship, good practices and good business and employee conduct. Some of them have called upon consulting, auditing and certification services, contributing to the accumulation of expertise in these areas. Enterprises have also promoted social dialogue on what constitutes responsible business conduct and have worked with stakeholders, including in the context of multi-stakeholder initiatives, to develop guidance for responsible business conduct. The Guidelines clarify the shared expectations for business conduct of the governments adhering to them and provide a point of reference for enterprises and for other stakeholders. Thus, the Guidelines both complement and reinforce private efforts to define and implement responsible business conduct.

8. Governments are co-operating with each other and with other actors to strengthen the international legal and policy framework in which business is conducted. The start of this process can be dated to the work of the International Labour Orqanisation in the earlv twentieth centurv. The adoption bv the United Nations in 1948 of the Universal Declaration of Human 
Rights was another landmark event. It was followed by the ongoing development of standards relevant for many areas of responsible business conduct - a process that continues to this day. The OECD has contributed in important ways to this process through the development of standards covering such areas as the environment, the fight against corruption, consumer interests, corporate governance and taxation.

9. The common aim of the governments adhering to the Guidelines is to encourage the positive contributions that multinational enterprises can make to economic, environmental and social progress and to minimise the difficulties to which their various operations may give rise. In working towards this goal, governments find themselves in partnership with the many businesses, trade unions and other non-governmental organisations that are working in their own ways toward the same end. Governments can help by providing effective domestic policy frameworks that include stable macroeconomic policy, non-discriminatory treatment of enterprises, appropriate regulation and prudential supervision, an impartial system of courts and law enforcement and efficient and honest public administration. Governments can also help by maintaining and promoting appropriate standards and policies in support of sustainable development and by engaging in ongoing reforms to ensure that public sector activity is efficient and effective. Governments adhering to the Guidelines are committed to continuous improvement of both domestic and international policies with a view to improving the welfare and living standards of all people.

\section{Concepts and Principles}

1. The Guidelines are recommendations jointly addressed by governments to multinational enterprises. They provide principles and standards of good practice consistent with applicable laws and internationally recognised standards. Observance of the Guidelines by enterprises is voluntary and not legally enforceable. Nevertheless, some matters covered by the Guidelines may also be regulated by national law or international commitments.

2. Obeying domestic laws is the first obligation of enterprises. The Guidelines are not a substitute for nor should they be considered to override domestic law and regulation. While the Guidelines extend beyond the law in many cases, they should not and are not intended to place an enterprise in situations where it faces conflicting requirements. However, in countries where domestic laws and regulations conflict with the principles and standards of the Guidelines, enterprises should seek ways to honour such principles and standards to the fullest extent which does not place them in violation of domestic law.

3. Since the operations of multinational enterprises extend throughout the world, international co-operation in this field should extend to all countries. Governments adhering to the Guidelines encourage the enterprises operating on their territories to observe the Guidelines wherever they operate, while taking into account the particular circumstances of each host country.

4. A precise definition of multinational enterprises is not required for the purposes of the Guidelines. These enterprises operate in all sectors of the economy. They usually comprise companies or other entities established in more than one country and so linked that they may co-ordinate their operations in various ways. While one or more of these entities may be able to exercise a significant influence over the activities of others, their degree of autonomy within the enterprise may vary widely from one multinational enterprise to another. Ownership may be private, State or mixed. The Guidelines are addressed to all the entities within the multinational enterprise (parent companies and/or local entities). According to the actual distribution of responsibilities among them, the different entities are expected to co operate and to assist one another to facilitate observance of the Guidelines.

5. The Guidelines are not aimed at introducing differences of treatment between multinational and domestic enterprises; they reflect good practice for all. Accordingly, multinational and domestic enterprises are subject to the same expectations in respect of their conduct wherever the Guidelines are relevant to both.

6. Governments wish to encourage the widest possible observance of the Guidelines. While it is acknowledged that small- and medium-sized enterprises may not have the same capacities as larger enterprises, governments adhering to the Guidelines nevertheless encourage them to observe the Guidelines' recommendations to the fullest extent possible.

7. Governments adhering to the Guidelines should not use them for protectionist purposes nor use them in a way that calls into question the comparative advantage of any country where multinational enterprises invest.

8. Governments have the right to prescribe the conditions under which multinational enterprises operate within their jurisdictions, subject to international law. The entities of a multinational enterprise located in various countries are subject to the laws applicable in these countries. When multinational enterprises are subject to conflicting requirements by adhering countries or third countries, the governments concerned are encouraged to co operate in good faith with a view to resolving problems that may arise.

9. Governments adhering to the Guidelines set them forth with the understanding that they will fulfil their responsibilities to treat enterprises equitably and in accordance with international law and with their contractual obligations.

10. The use of appropriate international dispute settlement mechanisms, including arbitration, is encouraged as a means of facilitating the resolution of legal problems arising between enterprises and host country governments.

11. Governments adhering to the Guidelines will implement them and encourage their use. They will establish National Contact Points that promote the Guidelines and act as a forum for discussion of all matters relating to the Guidelines. The adhering Governments will also participate in appropriate review and consultation procedures to address issues concerning interpretation of the Guidelines in a changing world.

\section{General Policies}


Enterprises should take fully into account established policies in the countries in which they operate, and consider the views of other stakeholders. In this regard:

A. Enterprises should:

1. Contribute to economic, environmental and social progress with a view to achieving sustainable development.

2. Respect the internationally recognised human rights of those affected by their activities.

3. Encourage local capacity building through close co-operation with the local community, including business interests, as well as developing the enterprise's activities in domestic and foreign markets, consistent with the need for sound commercial practice.

4. Encourage human capital formation, in particular by creating employment opportunities and facilitating training opportunities for employees.

5. Refrain from seeking or accepting exemptions not contemplated in the statutory or regulatory framework related to human rights, environmental, health, safety, labour, taxation, financial incentives, or other issues.

6. Support and uphold good corporate governance principles and develop and apply good corporate governance practices, including throughout enterprise groups.

7. Develop and apply effective self-regulatory practices and management systems that foster a relationship of confidence and mutual trust between enterprises and the societies in which they operate.

8. Promote awareness of and compliance by workers employed by multinational enterprises with respect to company policies through appropriate dissemination of these policies, including through training programmes.

9. Refrain from discriminatory or disciplinary action against workers who make bona fide reports to management or, as appropriate, to the competent public authorities, on practices that contravene the law, the Guidelines or the enterprise's policies.

10. Carry out risk-based due diligence, for example by incorporating it into their enterprise risk management systems, to identify, prevent and mitigate actual and potential adverse impacts as described in paragraphs 11 and 12 , and account for how these impacts are addressed. The nature and extent of due diligence depend on the circumstances of a particular situation.

11. Avoid causing or contributing to adverse impacts on matters covered by the Guidelines, through their own activities, and address such impacts when they occur.

12. Seek to prevent or mitigate an adverse impact where they have not contributed to that impact, when the impact is nevertheless directly linked to their operations, products or services by a business relationship. This is not intended to shift responsibility from the entity causing an adverse impact to the enterprise with which it has a business relationship.

13. In addition to addressing adverse impacts in relation to matters covered by the Guidelines, encourage, where practicable, business partners, including suppliers and sub-contractors, to apply principles of responsible business conduct compatible with the Guidelines.

14. Engage with relevant stakeholders in order to provide meaningful opportunities for their views to be taken into account in relation to planning and decision making for projects or other activities that may significantly impact local communities.

15. Abstain from any improper involvement in local political activities.

B. Enterprises are encouraged to:

1. Support, as appropriate to their circumstances, cooperative efforts in the appropriate fora to promote Internet Freedom through respect of freedom of expression, assembly and association online.

2. Engage in or support, where appropriate, private or multi-stakeholder initiatives and social dialogue on responsible supply chain management while ensuring that these initiatives take due account of their social and economic effects on developing countries and of existing internationally recognised standards.

\section{Disclosure}

1. Enterprises should ensure that timely and accurate information is disclosed on all material matters regarding their activities, structure, financial situation, performance, ownership and governance. This information should be disclosed for the enterprise as a whole, and, where appropriate, along business lines or geographic areas. Disclosure policies of enterprises should be tailored to the nature, size and location of the enterprise, with due regard taken of costs, business confidentiality and other competitive 
concerns.

2. Disclosure policies of enterprises should include, but not be limited to, material information on:

a) The financial and operating results of the enterprise;

b) Enterprise objectives;

c) Major share ownership and voting rights, including the structure of a group of enterprises and intra-group relations, as well as control enhancing mechanisms;

d) Remuneration policy for members of the board and key executives, and information about board members, including qualifications, the selection process, other enterprise directorships and whether each board member is regarded as independent by the board;

e) Related party transactions;

f) Foreseeable risk factors;

g) Issues regarding workers and other stakeholders;

h) Governance structures and policies, in particular, the content of any corporate governance code or policy and its implementation process.

3. Enterprises are encouraged to communicate additional information that could include:

a) value statements or statements of business conduct intended for public disclosure including, depending on its relevance for the enterprise's activities, information on the enterprise's policies relating to matters covered by the Guidelines;

b) policies and other codes of conduct to which the enterprise subscribes, their date of adoption and the countries and entities to which such statements apply;

c) its performance in relation to these statements and codes;

d) information on internal audit, risk management and legal compliance systems;

e) information on relationships with workers and other stakeholders.

4. Enterprises should apply high quality standards for accounting, and financial as well as non-financial disclosure, including environmental and social reporting where they exist. The standards or policies under which information is compiled and published should be reported. An annual audit should be conducted by an independent, competent and qualified auditor in order to provide an external and objective assurance to the board and shareholders that the financial statements fairly represent the financial position and performance of the enterprise in all material respects.

\section{Human Rights}

States have the duty to protect human rights. Enterprises should, within the framework of internationally recognised human rights, the international human rights obligations of the countries in which they operate as well as relevant domestic laws and regulations:

1. Respect human rights, which means they should avoid infringing on the human rights of others and should address adverse human rights impacts with which they are involved.

2. Within the context of their own activities, avoid causing or contributing to adverse human rights impacts and address such impacts when they occur.

3. Seek ways to prevent or mitigate adverse human rights impacts that are directly linked to their business operations, products or services by a business relationship, even if they do not contribute to those impacts.

4. Have a policy commitment to respect human rights.

5. Carry out human rights due diligence as appropriate to their size, the nature and context of operations and the severity of the risks of adverse human rights impacts.

6. Provide for or co-operate through legitimate processes in the remediation of adverse human rights impacts where they identify that they have caused or contributed to these impacts.

\section{Employment and Industrial Relations}


Enterprises should, within the framework of applicable law, regulations and prevailing labour relations and employment practices and applicable international labour standards:

1.

a) Respect the right of workers employed by the multinational enterprise to establish or join trade unions and representative organisations of their own choosing;

b) Respect the right of workers employed by the multinational enterprise to have trade unions and representative organisations of their own choosing recognised for the purpose of collective bargaining, and engage in constructive

negotiations, either individually or through employers' associations, with such representatives with a view to reaching agreements on terms and conditions of employment;

c) Contribute to the effective abolition of child labour, and take immediate and effective measures to secure the prohibition and elimination of the worst forms of child labour as a matter of urgency;

d) Contribute to the elimination of all forms of forced or compulsory labour and take adequate steps to ensure that forced or compulsory labour does not exist in their operations;

e) Be guided throughout their operations by the principle of equality of opportunity and treatment in employment and not discriminate against their workers with respect to employment or occupation on such grounds as race, colour, sex, religion, political opinion, national extraction or social origin, or other status, unless selectivity concerning worker characteristics furthers established governmental policies which specifically promote greater equality of employment opportunity or relates to the inherent requirements of a job.

2.

a) Provide such facilities to workers' representatives as may be necessary to assist in the development of effective collective agreements;

b) Provide information to workers' representatives which is needed for meaningful negotiations on conditions of employment;

c) Provide information to workers and their representatives which enables them to obtain a true and fair view of the performance of the entity or, where appropriate, the enterprise as a whole.

3. Promote consultation and co-operation between employers and workers and their representatives on matters of mutual concern.

4.

a) Observe standards of employment and industrial relations not less favourable than those observed by comparable employers in the host country;

b) When multinational enterprises operate in developing countries, where comparable employers may not exist, provide the best possible wages, benefits and conditions of work, within the framework of government policies. These should be related to the economic position of the enterprise, but should be at least adequate to satisfy the basic needs of the workers and their families;

c) Take adequate steps to ensure occupational health and safety in their operations.

5. In their operations, to the greatest extent practicable, employ local workers and provide training with a view to improving skill levels, in co-operation with worker representatives and, where appropriate, relevant governmental authorities.

6. In considering changes in their operations which would have major employment effects, in particular in the case of the closure of an entity involving collective lay-offs or dismissals, provide reasonable notice of such changes to representatives of the workers in their employment and their organisations, and, where appropriate, to the relevant governmental authorities, and cooperate with the worker representatives and appropriate governmental authorities so as to mitigate to the maximum extent practicable adverse effects. In light of the specific circumstances of each case, it would be appropriate if management were able to give such notice prior to the final decision being taken. Other means may also be employed to provide meaningful co-operation to mitigate the effects of such decisions.

7. In the context of bona fide negotiations with workers' representatives on conditions of employment, or while workers are exercising a right to organise, not threaten to transfer the whole or part of an operating unit from the country concerned nor transfer workers from the enterprises' component entities in other countries in order to influence unfairly those negotiations or to hinder the exercise of a right to organise.

8. Enable authorised representatives of the workers in their employment to negotiate on collective bargaining or labourmanagement relations issues and allow the parties to consult on matters of mutual concern with representatives of management 
who are authorised to take decisions on these matters.

\section{Environment}

Enterprises should, within the framework of laws, regulations and administrative practices in the countries in which they operate, and in consideration of relevant international agreements, principles, objectives, and standards, take due account of the need to protect the environment, public health and safety, and generally to conduct their activities in a manner contributing to the wider goal of sustainable development. In particular, enterprises should:

1. Establish and maintain a system of environmental management appropriate to the enterprise, including:

a) Collection and evaluation of adequate and timely information regarding the environmental, health, and safety impacts of their activities:

b) Establishment of measurable objectives and, where appropriate, targets for improved environmental performance and resource utilisation, including periodically reviewing the continuing relevance of these objectives; where appropriate, targets should be consistent with relevant national policies and international environmental commitments; and

c) Regular monitoring and verification of progress toward environmental, health, and safety objectives or targets.

2. Taking into account concerns about cost, business confidentiality, and the protection of intellectual property rights:

a) Provide the public and workers with adequate, measureable and verifiable (where applicable) and timely information on the potential environment, health and safety impacts of the activities of the enterprise, which could include reporting on progress in improving environmental performance; and

b) Engage in adequate and timely communication and consultation with the communities directly affected by the environmental, health and safety policies of the enterprise and by their implementation.

3. Assess, and address in decision-making, the foreseeable environmental, health, and safety-related impacts associated with the processes, goods and services of the enterprise over their full life cycle with a view to avoiding or, when unavoidable, mitigating them. Where these proposed activities may have significant environmental, health, or safety impacts, and where they are subject to a decision of a competent authority, prepare an appropriate environmental impact assessment.

4. Consistent with the scientific and technical understanding of the risks, where there are threats of serious damage to the environment, taking also into account human health and safety, not use the lack of full scientific certainty as a reason for postponing cost-effective measures to prevent or minimise such damage.

5. Maintain contingency plans for preventing, mitigating, and controlling serious environmental and health damage from their operations, including accidents and emergencies; and mechanisms for immediate reporting to the competent authorities.

6. Continually seek to improve corporate environmental performance, at the level of the enterprise and, where appropriate, of its supply chain, by encouraging such activities as:

a) Adoption of technologies and operating procedures in all parts of the enterprise that reflect standards concerning environmental performance in the best performing part of the enterprise

b) Development and provision of products or services that have no undue environmental impacts; are safe in their intended use; reduce greenhouse gas emissions; are efficient in their consumption of energy and natural resources; can be reused, recycled, or disposed of safely;

c) Promoting higher levels of awareness among customers of the environmental implications of using the products and services of the enterprise, including, by providing accurate information on their products (for example, on greenhouse gas emissions, biodiversity, resource efficiency, or other environmental issues); and

d) Exploring and assessing ways of improving the environmental performance of the enterprise over the longer term, for instance by developing strategies for emission reduction, efficient resource utilisation and recycling, substitution or reduction of use of toxic substances, or strategies on biodiversity.

7. Provide adequate education and training to workers in environmental health and safety matters, including the handling of hazardous materials and the prevention of environmental accidents, as well as more general environmental management areas, such as environmental impact assessment procedures, public relations, and environmental technologies.

8. Contribute to the development of environmentally meaningful and economically efficient public policy, for example, by means of partnerships or initiatives that will enhance environmental awareness and protection.

\section{Combating Bribery, Bribe Solicitation and Extortion}

Enterprises should not, directly or indirectly, offer, promise, give, or demand a bribe or other undue advantage to obtain or retain husiness or nther imnroner advantace Fnternrises shnuld alsn resist the solicitation of hrihes and extortinn In narticular 
enterprises should:

1. Not offer, promise or give undue pecuniary or other advantage to public officials or the employees of business partners. Likewise, enterprises should not request, agree to or accept undue pecuniary or other advantage from public officials or the employees of business partners. Enterprises should not use third parties such as agents and other intermediaries, consultants, representatives, distributors, consortia, contractors and suppliers and joint venture partners for channelling undue pecuniary or other advantages to public officials, or to employees of their business partners or to their relatives or business associates

2. Develop and adopt adequate internal controls, ethics and compliance programmes or measures for preventing and detecting bribery, developed on the basis of a risk assessment addressing the individual circumstances of an enterprise, in particular the bribery risks facing the enterprise (such as its geographical and industrial sector of operation). These internal controls, ethics and compliance programmes or measures should include a system of financial and accounting procedures, including a system of internal controls, reasonably designed to ensure the maintenance of fair and accurate books, records, and accounts, to ensure that they cannot be used for the purpose of bribing or hiding bribery. Such individual circumstances and bribery risks should be regularly monitored and re-assessed as necessary to ensure the enterprise's internal controls, ethics and compliance programme or measures are adapted and continue to be effective, and to mitigate the risk of enterprises becoming complicit in bribery, bribe solicitation and extortion.

3. Prohibit or discourage, in internal company controls, ethics and compliance programmes or measures, the use of small facilitation payments, which are generally illegal in the countries where they are made, and, when such payments are made, accurately record these in books and financial records.

4. Ensure, taking into account the particular bribery risks facing the enterprise, properly documented due diligence pertaining to the hiring, as well as the appropriate and regular oversight of agents, and that remuneration of agents is appropriate and for legitimate services only. Where relevant, a list of agents engaged in connection with transactions with public bodies and Stateowned enterprises should be kept and made available to competent authorities, in accordance with applicable public disclosure requirements.

5. Enhance the transparency of their activities in the fight against bribery, bribe solicitation and extortion. Measures could include making public commitments against bribery, bribe solicitation and extortion, and disclosing the management systems and the internal controls, ethics and compliance programmes or measures adopted by enterprises in order to honour these commitments. Enterprises should also foster openness and dialogue with the public so as to promote its awareness of and cooperation with the fight against bribery, bribe solicitation and extortion.

6. Promote employee awareness of and compliance with company policies and internal controls, ethics and compliance programmes or measures against bribery, bribe solicitation and extortion through appropriate dissemination of such policies, programmes or measures and through training programmes and disciplinary procedures.

7. Not make illegal contributions to candidates for public office or to political parties or to other political organisations. Political contributions should fully comply with public disclosure requirements and should be reported to senior management.

\section{Consumer Interests}

When dealing with consumers, enterprises should act in accordance with fair business, marketing and advertising practices and should take all reasonable steps to ensure the quality and reliability of the goods and services that they provide. In particular, they should:

1. Ensure that the goods and services they provide meet all agreed or legally required standards for consumer health and safety, including those pertaining to health warnings and safety information.

2. Provide accurate, verifiable and clear information that is sufficient to enable consumers to make informed decisions, including information on the prices and, where appropriate, content, safe use, environmental attributes, maintenance, storage and disposal of goods and services. Where feasible this information should be provided in a manner that facilitates consumers' ability to compare products.

3. Provide consumers with access to fair, easy to use, timely and effective non-judicial dispute resolution and redress mechanisms, without unnecessary cost or burden.

4. Not make representations or omissions, nor engage in any other practices, that are deceptive, misleading, fraudulent or unfair.

5. Support efforts to promote consumer education in areas that relate to their business activities, with the aim of, inter alia, improving the ability of consumers to: i) make informed decisions involving complex goods, services and markets, ii) better understand the economic, environmental and social impact of their decisions and iii) support sustainable consumption.

6. Respect consumer privacy and take reasonable measures to ensure the security of personal data that they collect, store, process or disseminate.

7. Co-operate fully with public authorities to prevent and combat deceptive marketing practices (including misleading advertising

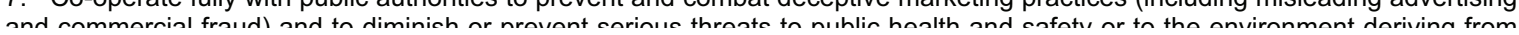


the consumption, use or disposal of their goods and services.

8. Take into consideration, in applying the above principles, i) the needs of vulnerable and disadvantaged consumers and ii) the specific challenges that e-commerce may pose for consumers.

\section{Science and Technology}

Enterprises should:

1. Endeavour to ensure that their activities are compatible with the science and technology (S\&T) policies and plans of the countries in which they operate and as appropriate contribute to the development of local and national innovative capacity.

2. Adopt, where practicable in the course of their business activities, practices that permit the transfer and rapid diffusion of technologies and know how, with due regard to the protection of intellectual property rights.

3. When appropriate, perform science and technology development work in host countries to address local market needs, as well as employ host country personnel in an S\&T capacity and encourage their training, taking into account commercial needs.

4. When granting licenses for the use of intellectual property rights or when otherwise transferring technology, do so on reasonable terms and conditions and in a manner that contributes to the long term sustainable development prospects of the host country.

5. Where relevant to commercial objectives, develop ties with local universities, public research institutions, and participate in co operative research projects with local industry or industry associations.

\section{Competition}

Enterprises should:

1. Carry out their activities in a manner consistent with all applicable competition laws and regulations, taking into account the competition laws of all jurisdictions in which the activities may have anti-competitive effects.

2. Refrain from entering into or carrying out anti-competitive agreements among competitors, including agreements to:
a) fix prices:
b) make rigged bids (collusive tenders);
c) establish output restrictions or quotas; or

d) share or divide markets by allocating customers, suppliers, territories or lines of commerce.

3. Co-operate with investigating competition authorities by, among other things and subject to applicable law and appropriate safeguards, providing responses as promptly and completely as practicable to requests for information, and considering the use of available instruments, such as waivers of confidentiality where appropriate, to promote effective and efficient co-operation among investigating authorities.

4. Regularly promote employee awareness of the importance of compliance with all applicable competition laws and regulations, and, in particular, train senior management of the enterprise in relation to competition issues.

\section{Taxation}

1. It is important that enterprises contribute to the public finances of host countries by making timely payment of their tax liabilities. In particular, enterprises should comply with both the letter and spirit of the tax laws and regulations of the countries in which they operate. Complying with the spirit of the law means discerning and following the intention of the legislature. It does not require an enterprise to make payment in excess of the amount legally required pursuant to such an interpretation. Tax compliance includes such measures as providing to the relevant authorities timely information that is relevant or required by law for purposes of the correct determination of taxes to be assessed in connection with their operations and conforming transfer pricing practices to the arm's length principle.

2. Enterprises should treat tax governance and tax compliance as important elements of their oversight and broader risk management systems. In particular, corporate boards should adopt tax risk management strategies to ensure that the financial, regulatory and reputational risks associated with taxation are fully identified and evaluated.

\section{ANNEX 2}




\section{CONFLICTING REQUIREMENTS}

\section{a) General considerations}

In contemplating new legislation, action under existing legislation or other exercise of jurisdiction which may conflict with the legal requirements or established policies of another Member country and lead to conflicting requirements being imposed on multinational enterprises, the Member countries concerned should:

i) Have regard to relevant principles of international law;

ii) Endeavour to avoid or minimise such conflicts and the problems to which they give rise by following an approach of moderation and restraint, respecting and accommodating the interests of other Member countries; $\frac{\text { [2] }}{\text {. }}$

iii) Take fully into account the sovereignty and legitimate economic, law enforcement and other interests of other Member countries;

iv) Bear in mind the importance of permitting the observance of contractual obligations and the possible adverse impact of measures having a retroactive effect. Member countries should endeavour to promote co-operation as an alternative to unilateral action to avoid or minimise conflicting requirements and problems arising therefrom. Member countries should on request consult one another and endeavour to arrive at mutually acceptable solutions to such problems.

b) Practical approaches

Member countries recognised that in the majority of circumstances, effective co-operation may best be pursued on a bilateral basis. On the other hand, there may be cases where the multilateral approach could be more effective. Member countries should therefore be prepared to:

i) Develop mutually beneficial, practical and appropriately safeguarded bilateral arrangements, formal or informal, for notification to and consultation with other Member countries;

ii) Give prompt and sympathetic consideration to requests for notification and bilateral consultation on an ad hoc basis made by any Member country which considers that its interests may be affected by any measure of the type referred to above, taken by another Member country with which it does not have such bilateral arrangements;

iii) Inform the other concerned Member countries as soon as practicable of new legislation or regulations proposed by their Governments for adoption which have significant potential for conflict with the legal requirements or established policies of other Member countries and for giving rise to conflicting requirements being imposed on multinational enterprises;

iv) Give prompt and sympathetic consideration to requests by other Member countries for consultation in the CIME or through other mutually acceptable arrangements. Such consultations would be facilitated by notification at the earliest stage practicable;

v) Give prompt and full consideration to proposals which may be made by other Member countries in any such consultations that would lessen or eliminate conflicts.

These procedures do not apply to those aspects of restrictive business practices or other matters which are the subject of existing OECD arrangements.

Relevant body:

[1] As at 30 June 2012, adhering governments are those of all OECD members, as well as Argentina, Brazil, Colombia, Egypt, Latvia, Lithuania, Morocco, Peru, Romania and Tunisia. The European Community has been invited to associate itself with the section on National Treatment on matters falling within its competence.

[2]. Applying the principle of comity, as it is understood in some Member countries, includes following an approach of this nature in exercising one's jurisdiction.

Please note that this is a print out version. The only official and up to date version of this legal instrument is available online at: http://acts.oecd.org 
Organisation de Coopération et de Développement Économiques

COUNCIL

English - Or. English

Meeting of the Council at Ministerial Level, 25-26 May 2011

OECD GUIDELINES FOR MULTINATIONAL ENTERPRISES: UPDATE 2011 
$\mathrm{C} / \mathrm{MIN}(2011) 11$

\section{TABLE OF CONTENTS}

AMENDMENT OF ANNEX I OF THE DECLARATION ON INTERNATIONAL INVESTMENT AND

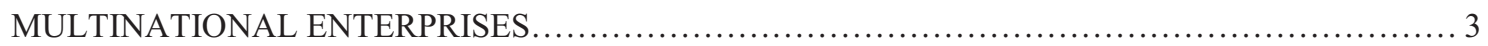

AMENDMENT OF THE DECISION OF THE COUNCIL ON THE OECD GUIDELINES FOR MULTINATIONAL ENTERPRISES. 
C/MIN(2011)11

\title{
AMENDMENT OF ANNEX I OF THE DECLARATION ON INTERNATIONAL INVESTMENT AND MULTINATIONAL ENTERPRISES [C(76)99/FINAL AS AMENDED]
}

\author{
OECD Guidelines for Multinational Enterprises: \\ Recommendations for responsible business conduct in a global context
}

\section{Preface}

1. The OECD Guidelines for Multinational Enterprises (the Guidelines) are recommendations addressed by governments to multinational enterprises. The Guidelines aim to ensure that the operations of these enterprises are in harmony with government policies, to strengthen the basis of mutual confidence between enterprises and the societies in which they operate, to help improve the foreign investment climate and to enhance the contribution to sustainable development made by multinational enterprises. The Guidelines are part of the OECD Declaration on International Investment and Multinational Enterprises the other elements of which relate to national treatment, conflicting requirements on enterprises, and international investment incentives and disincentives. The Guidelines provide voluntary principles and standards for responsible business conduct consistent with applicable laws and internationally recognised standards. However, the countries adhering to the Guidelines make a binding commitment to implement them in accordance with the Decision of the OECD Council on the OECD Guidelines for Multinational Enterprises. Furthermore, matters covered by the Guidelines may also be the subject of national law and international commitments.

2. International business has experienced far-reaching structural change and the Guidelines themselves have evolved to reflect these changes. With the rise of service and knowledgeintensive industries and the expansion of the Internet economy, service and technology enterprises are playing an increasingly important role in the international marketplace. Large enterprises still account for a major share of international investment, and there is a trend toward large-scale international mergers. At the same time, foreign investment by small- and mediumsized enterprises has also increased and these enterprises now play a significant role on the international scene. Multinational enterprises, like their domestic counterparts, have evolved to encompass a broader range of business arrangements and organisational forms. Strategic alliances and closer relations with suppliers and contractors tend to blur the boundaries of the enterprise.

3. The rapid evolution in the structure of multinational enterprises is also reflected in their operations in the developing world, where foreign direct investment has grown rapidly. In developing countries, multinational enterprises have diversified beyond primary production and extractive industries into manufacturing, assembly, domestic market development and services. Another key development is the emergence of multinational enterprises based in developing countries as major international investors.

4. The activities of multinational enterprises, through international trade and investment, have strengthened and deepened the ties that join the countries and regions of the world. These activities bring substantial benefits to home and host countries. These benefits accrue when multinational enterprises supply the products and services that consumers want to buy at competitive prices and when they provide fair returns to suppliers of capital. Their trade and investment activities contribute to the efficient use of capital, technology and human and natural 
C/MIN(2011)11

resources. They facilitate the transfer of technology among the regions of the world and the development of technologies that reflect local conditions. Through both formal training and onthe-job learning enterprises also promote the development of human capital and creating employment opportunities in host countries.

5. The nature, scope and speed of economic changes have presented new strategic challenges for enterprises and their stakeholders. Multinational enterprises have the opportunity to implement best practice policies for sustainable development that seek to ensure coherence between economic, environmental and social objectives. The ability of multinational enterprises to promote sustainable development is greatly enhanced when trade and investment are conducted in a context of open, competitive and appropriately regulated markets.

6. Many multinational enterprises have demonstrated that respect for high standards of business conduct can enhance growth. Today's competitive forces are intense and multinational enterprises face a variety of legal, social and regulatory settings. In this context, some enterprises may be tempted to neglect appropriate principles and standards of conduct in an attempt to gain undue competitive advantage. Such practices by the few may call into question the reputation of the many and may give rise to public concerns.

7. Many enterprises have responded to these public concerns by developing internal programmes, guidance and management systems that underpin their commitment to good corporate citizenship, good practices and good business and employee conduct. Some of them have called upon consulting, auditing and certification services, contributing to the accumulation of expertise in these areas. Enterprises have also promoted social dialogue on what constitutes responsible business conduct and have worked with stakeholders, including in the context of multistakeholder initiatives, to develop guidance for responsible business conduct. The Guidelines clarify the shared expectations for business conduct of the governments adhering to them and provide a point of reference for enterprises and for other stakeholders. Thus, the Guidelines both complement and reinforce private efforts to define and implement responsible business conduct.

8. Governments are co-operating with each other and with other actors to strengthen the international legal and policy framework in which business is conducted. The start of this process can be dated to the work of the International Labour Organisation in the early twentieth century. The adoption by the United Nations in 1948 of the Universal Declaration of Human Rights was another landmark event. It was followed by the ongoing development of standards relevant for many areas of responsible business conduct - a process that continues to this day. The OECD has contributed in important ways to this process through the development of standards covering such areas as the environment, the fight against corruption, consumer interests, corporate governance and taxation.

9. The common aim of the governments adhering to the Guidelines is to encourage the positive contributions that multinational enterprises can make to economic, environmental and social progress and to minimise the difficulties to which their various operations may give rise. In working towards this goal, governments find themselves in partnership with the many businesses, trade unions and other non-governmental organisations that are working in their own ways toward the same end. Governments can help by providing effective domestic policy frameworks that include stable macroeconomic policy, non-discriminatory treatment of enterprises, appropriate regulation and prudential supervision, an impartial system of courts and law enforcement and efficient and honest public administration. Governments can also help by maintaining and promoting appropriate standards and policies in support of sustainable development and by engaging in ongoing reforms to ensure that public sector activity is efficient 
C/MIN(2011)11

and effective. Governments adhering to the Guidelines are committed to continuous improvement of both domestic and international policies with a view to improving the welfare and living standards of all people.

\section{Concepts and Principles}

1. The Guidelines are recommendations jointly addressed by governments to multinational enterprises. They provide principles and standards of good practice consistent with applicable laws and internationally recognised standards. Observance of the Guidelines by enterprises is voluntary and not legally enforceable. Nevertheless, some matters covered by the Guidelines may also be regulated by national law or international commitments.

2. Obeying domestic laws is the first obligation of enterprises. The Guidelines are not a substitute for nor should they be considered to override domestic law and regulation. While the Guidelines extend beyond the law in many cases, they should not and are not intended to place an enterprise in situations where it faces conflicting requirements. However, in countries where domestic laws and regulations conflict with the principles and standards of the Guidelines, enterprises should seek ways to honour such principles and standards to the fullest extent which does not place them in violation of domestic law.

3. Since the operations of multinational enterprises extend throughout the world, international cooperation in this field should extend to all countries. Governments adhering to the Guidelines encourage the enterprises operating on their territories to observe the Guidelines wherever they operate, while taking into account the particular circumstances of each host country.

4. A precise definition of multinational enterprises is not required for the purposes of the Guidelines. These enterprises operate in all sectors of the economy. They usually comprise companies or other entities established in more than one country and so linked that they may coordinate their operations in various ways. While one or more of these entities may be able to exercise a significant influence over the activities of others, their degree of autonomy within the enterprise may vary widely from one multinational enterprise to another. Ownership may be private, State or mixed. The Guidelines are addressed to all the entities within the multinational enterprise (parent companies and/or local entities). According to the actual distribution of responsibilities among them, the different entities are expected to co-operate and to assist one another to facilitate observance of the Guidelines.

5. The Guidelines are not aimed at introducing differences of treatment between multinational and domestic enterprises; they reflect good practice for all. Accordingly, multinational and domestic enterprises are subject to the same expectations in respect of their conduct wherever the Guidelines are relevant to both.

6. Governments wish to encourage the widest possible observance of the Guidelines. While it is acknowledged that small- and medium-sized enterprises may not have the same capacities as larger enterprises, governments adhering to the Guidelines nevertheless encourage them to observe the Guidelines' recommendations to the fullest extent possible.

7. Governments adhering to the Guidelines should not use them for protectionist purposes nor use them in a way that calls into question the comparative advantage of any country where multinational enterprises invest.

8. Governments have the right to prescribe the conditions under which multinational enterprises operate within their jurisdictions, subject to international law. The entities of a multinational 
$\mathrm{C} / \mathrm{MIN}(2011) 11$

enterprise located in various countries are subject to the laws applicable in these countries. When multinational enterprises are subject to conflicting requirements by adhering countries or third countries, the governments concerned are encouraged to co-operate in good faith with a view to resolving problems that may arise.

9. Governments adhering to the Guidelines set them forth with the understanding that they will fulfil their responsibilities to treat enterprises equitably and in accordance with international law and with their contractual obligations.

10. The use of appropriate international dispute settlement mechanisms, including arbitration, is encouraged as a means of facilitating the resolution of legal problems arising between enterprises and host country governments.

11. Governments adhering to the Guidelines will implement them and encourage their use. They will establish National Contact Points that promote the Guidelines and act as a forum for discussion of all matters relating to the Guidelines. The adhering Governments will also participate in appropriate review and consultation procedures to address issues concerning interpretation of the Guidelines in a changing world.

\section{General Policies}

Enterprises should take fully into account established policies in the countries in which they operate, and consider the views of other stakeholders. In this regard:

A. Enterprises should:

1. Contribute to economic, environmental and social progress with a view to achieving sustainable development.

2. Respect the internationally recognised human rights of those affected by their activities.

3. Encourage local capacity building through close co-operation with the local community, including business interests, as well as developing the enterprise's activities in domestic and foreign markets, consistent with the need for sound commercial practice.

4. Encourage human capital formation, in particular by creating employment opportunities and facilitating training opportunities for employees.

5. Refrain from seeking or accepting exemptions not contemplated in the statutory or regulatory framework related to human rights, environmental, health, safety, labour, taxation, financial incentives, or other issues.

6. Support and uphold good corporate governance principles and develop and apply good corporate governance practices, including throughout enterprise groups.

7. Develop and apply effective self-regulatory practices and management systems that foster a relationship of confidence and mutual trust between enterprises and the societies in which they operate.

8. Promote awareness of and compliance by workers employed by multinational enterprises with respect to company policies through appropriate dissemination of these policies, including through training programmes. 
9. Refrain from discriminatory or disciplinary action against workers who make bona fide reports to management or, as appropriate, to the competent public authorities, on practices that contravene the law, the Guidelines or the enterprise's policies.

10. Carry out risk-based due diligence, for example by incorporating it into their enterprise risk management systems, to identify, prevent and mitigate actual and potential adverse impacts as described in paragraphs 11 and 12, and account for how these impacts are addressed. The nature and extent of due diligence depend on the circumstances of a particular situation.

11. Avoid causing or contributing to adverse impacts on matters covered by the Guidelines, through their own activities, and address such impacts when they occur.

12. Seek to prevent or mitigate an adverse impact where they have not contributed to that impact, when the impact is nevertheless directly linked to their operations, products or services by a business relationship. This is not intended to shift responsibility from the entity causing an adverse impact to the enterprise with which it has a business relationship.

13. In addition to addressing adverse impacts in relation to matters covered by the Guidelines, encourage, where practicable, business partners, including suppliers and sub-contractors, to apply principles of responsible business conduct compatible with the Guidelines.

14. Engage with relevant stakeholders in order to provide meaningful opportunities for their views to be taken into account in relation to planning and decision making for projects or other activities that may significantly impact local communities.

15. Abstain from any improper involvement in local political activities.

B. Enterprises are encouraged to:

1. Support, as appropriate to their circumstances, cooperative efforts in the appropriate fora to promote Internet Freedom through respect of freedom of expression, assembly and association online.

2. Engage in or support, where appropriate, private or multi-stakeholder initiatives and social dialogue on responsible supply chain management while ensuring that these initiatives take due account of their social and economic effects on developing countries and of existing internationally recognised standards.

\section{Disclosure}

1. Enterprises should ensure that timely and accurate information is disclosed on all material matters regarding their activities, structure, financial situation, performance, ownership and governance. This information should be disclosed for the enterprise as a whole, and, where appropriate, along business lines or geographic areas. Disclosure policies of enterprises should be tailored to the nature, size and location of the enterprise, with due regard taken of costs, business confidentiality and other competitive concerns.

2. Disclosure policies of enterprises should include, but not be limited to, material information on:

a) The financial and operating results of the enterprise;

b) Enterprise objectives; 
$\mathrm{C} / \mathrm{MIN}(2011) 11$

c) Major share ownership and voting rights, including the structure of a group of enterprises and intra-group relations, as well as control enhancing mechanisms;

d) Remuneration policy for members of the board and key executives, and information about board members, including qualifications, the selection process, other enterprise directorships and whether each board member is regarded as independent by the board;

e) Related party transactions;

f) Foreseeable risk factors;

g) Issues regarding workers and other stakeholders;

h) Governance structures and policies, in particular, the content of any corporate governance code or policy and its implementation process.

3. Enterprises are encouraged to communicate additional information that could include:

a) value statements or statements of business conduct intended for public disclosure including, depending on its relevance for the enterprise's activities, information on the enterprise's policies relating to matters covered by the Guidelines;

b) policies and other codes of conduct to which the enterprise subscribes, their date of adoption and the countries and entities to which such statements apply;

c) its performance in relation to these statements and codes;

d) information on internal audit, risk management and legal compliance systems;

e) information on relationships with workers and other stakeholders.

4. Enterprises should apply high quality standards for accounting, and financial as well as nonfinancial disclosure, including environmental and social reporting where they exist. The standards or policies under which information is compiled and published should be reported. An annual audit should be conducted by an independent, competent and qualified auditor in order to provide an external and objective assurance to the board and shareholders that the financial statements fairly represent the financial position and performance of the enterprise in all material respects.

\section{Human Rights}

States have the duty to protect human rights. Enterprises should, within the framework of internationally recognised human rights, the international human rights obligations of the countries in which they operate as well as relevant domestic laws and regulations:

1. Respect human rights, which means they should avoid infringing on the human rights of others and should address adverse human rights impacts with which they are involved.

2. Within the context of their own activities, avoid causing or contributing to adverse human rights impacts and address such impacts when they occur. 
3. Seek ways to prevent or mitigate adverse human rights impacts that are directly linked to their business operations, products or services by a business relationship, even if they do not contribute to those impacts.

4. Have a policy commitment to respect human rights.

5. Carry out human rights due diligence as appropriate to their size, the nature and context of operations and the severity of the risks of adverse human rights impacts.

6. Provide for or co-operate through legitimate processes in the remediation of adverse human rights impacts where they identify that they have caused or contributed to these impacts.

\section{Employment and Industrial Relations}

Enterprises should, within the framework of applicable law, regulations and prevailing labour relations and employment practices and applicable international labour standards:

1. a) Respect the right of workers employed by the multinational enterprise to establish or join trade unions and representative organisations of their own choosing;

b) Respect the right of workers employed by the multinational enterprise to have trade unions and representative organisations of their own choosing recognised for the purpose of collective bargaining, and engage in constructive negotiations, either individually or through employers' associations, with such representatives with a view to reaching agreements on terms and conditions of employment;

c) Contribute to the effective abolition of child labour, and take immediate and effective measures to secure the prohibition and elimination of the worst forms of child labour as a matter of urgency;

d) Contribute to the elimination of all forms of forced or compulsory labour and take adequate steps to ensure that forced or compulsory labour does not exist in their operations;

e) Be guided throughout their operations by the principle of equality of opportunity and treatment in employment and not discriminate against their workers with respect to employment or occupation on such grounds as race, colour, sex, religion, political opinion, national extraction or social origin, or other status, unless selectivity concerning worker characteristics furthers established governmental policies which specifically promote greater equality of employment opportunity or relates to the inherent requirements of a job.

2. a) Provide such facilities to workers' representatives as may be necessary to assist in the development of effective collective agreements;

b) Provide information to workers' representatives which is needed for meaningful negotiations on conditions of employment;

c) Provide information to workers and their representatives which enables them to obtain a true and fair view of the performance of the entity or, where appropriate, the enterprise as a whole.

3. Promote consultation and co-operation between employers and workers and their representatives on matters of mutual concern. 
$\mathrm{C} / \mathrm{MIN}(2011) 11$

4. a) Observe standards of employment and industrial relations not less favourable than those observed by comparable employers in the host country;

b) When multinational enterprises operate in developing countries, where comparable employers may not exist, provide the best possible wages, benefits and conditions of work, within the framework of government policies. These should be related to the economic position of the enterprise, but should be at least adequate to satisfy the basic needs of the workers and their families;

c) Take adequate steps to ensure occupational health and safety in their operations.

5. In their operations, to the greatest extent practicable, employ local workers and provide training with a view to improving skill levels, in co-operation with worker representatives and, where appropriate, relevant governmental authorities.

6. In considering changes in their operations which would have major employment effects, in particular in the case of the closure of an entity involving collective lay-offs or dismissals, provide reasonable notice of such changes to representatives of the workers in their employment and their organisations, and, where appropriate, to the relevant governmental authorities, and cooperate with the worker representatives and appropriate governmental authorities so as to mitigate to the maximum extent practicable adverse effects. In light of the specific circumstances of each case, it would be appropriate if management were able to give such notice prior to the final decision being taken. Other means may also be employed to provide meaningful cooperation to mitigate the effects of such decisions.

7. In the context of bona fide negotiations with workers' representatives on conditions of employment, or while workers are exercising a right to organise, not threaten to transfer the whole or part of an operating unit from the country concerned nor transfer workers from the enterprises' component entities in other countries in order to influence unfairly those negotiations or to hinder the exercise of a right to organise.

8. Enable authorised representatives of the workers in their employment to negotiate on collective bargaining or labour-management relations issues and allow the parties to consult on matters of mutual concern with representatives of management who are authorised to take decisions on these matters.

\section{Environment}

Enterprises should, within the framework of laws, regulations and administrative practices in the countries in which they operate, and in consideration of relevant international agreements, principles, objectives, and standards, take due account of the need to protect the environment, public health and safety, and generally to conduct their activities in a manner contributing to the wider goal of sustainable development. In particular, enterprises should:

1. Establish and maintain a system of environmental management appropriate to the enterprise, including:

a) Collection and evaluation of adequate and timely information regarding the environmental, health, and safety impacts of their activities;

b) Establishment of measurable objectives and, where appropriate, targets for improved environmental performance and resource utilisation, including periodically reviewing the 
C/MIN(2011)11

continuing relevance of these objectives; where appropriate, targets should be consistent with relevant national policies and international environmental commitments; and

c) Regular monitoring and verification of progress toward environmental, health, and safety objectives or targets.

2. Taking into account concerns about cost, business confidentiality, and the protection of intellectual property rights:

a) Provide the public and workers with adequate, measureable and verifiable (where applicable) and timely information on the potential environment, health and safety impacts of the activities of the enterprise, which could include reporting on progress in improving environmental performance; and

b) Engage in adequate and timely communication and consultation with the communities directly affected by the environmental, health and safety policies of the enterprise and by their implementation.

3. Assess, and address in decision-making, the foreseeable environmental, health, and safety-related impacts associated with the processes, goods and services of the enterprise over their full life cycle with a view to avoiding or, when unavoidable, mitigating them. Where these proposed activities may have significant environmental, health, or safety impacts, and where they are subject to a decision of a competent authority, prepare an appropriate environmental impact assessment.

4. Consistent with the scientific and technical understanding of the risks, where there are threats of serious damage to the environment, taking also into account human health and safety, not use the lack of full scientific certainty as a reason for postponing cost-effective measures to prevent or minimise such damage.

5. Maintain contingency plans for preventing, mitigating, and controlling serious environmental and health damage from their operations, including accidents and emergencies; and mechanisms for immediate reporting to the competent authorities.

6. Continually seek to improve corporate environmental performance, at the level of the enterprise and, where appropriate, of its supply chain, by encouraging such activities as:

a) Adoption of technologies and operating procedures in all parts of the enterprise that reflect standards concerning environmental performance in the best performing part of the enterprise;

b) Development and provision of products or services that have no undue environmental impacts; are safe in their intended use; reduce greenhouse gas emissions; are efficient in their consumption of energy and natural resources; can be reused, recycled, or disposed of safely;

c) Promoting higher levels of awareness among customers of the environmental implications of using the products and services of the enterprise, including, by providing accurate information on their products (for example, on greenhouse gas emissions, biodiversity, resource efficiency, or other environmental issues); and 
C/MIN(2011)11

d) Exploring and assessing ways of improving the environmental performance of the enterprise over the longer term, for instance by developing strategies for emission reduction, efficient resource utilisation and recycling, substitution or reduction of use of toxic substances, or strategies on biodiversity.

7. Provide adequate education and training to workers in environmental health and safety matters, including the handling of hazardous materials and the prevention of environmental accidents, as well as more general environmental management areas, such as environmental impact assessment procedures, public relations, and environmental technologies.

8. Contribute to the development of environmentally meaningful and economically efficient public policy, for example, by means of partnerships or initiatives that will enhance environmental awareness and protection.

\section{Combating Bribery, Bribe Solicitation and Extortion}

Enterprises should not, directly or indirectly, offer, promise, give, or demand a bribe or other undue advantage to obtain or retain business or other improper advantage. Enterprises should also resist the solicitation of bribes and extortion. In particular, enterprises should:

1. Not offer, promise or give undue pecuniary or other advantage to public officials or the employees of business partners. Likewise, enterprises should not request, agree to or accept undue pecuniary or other advantage from public officials or the employees of business partners. Enterprises should not use third parties such as agents and other intermediaries, consultants, representatives, distributors, consortia, contractors and suppliers and joint venture partners for channelling undue pecuniary or other advantages to public officials, or to employees of their business partners or to their relatives or business associates

2. Develop and adopt adequate internal controls, ethics and compliance programmes or measures for preventing and detecting bribery, developed on the basis of a risk assessment addressing the individual circumstances of an enterprise, in particular the bribery risks facing the enterprise (such as its geographical and industrial sector of operation). These internal controls, ethics and compliance programmes or measures should include a system of financial and accounting procedures, including a system of internal controls, reasonably designed to ensure the maintenance of fair and accurate books, records, and accounts, to ensure that they cannot be used for the purpose of bribing or hiding bribery. Such individual circumstances and bribery risks should be regularly monitored and re-assessed as necessary to ensure the enterprise's internal controls, ethics and compliance programme or measures are adapted and continue to be effective, and to mitigate the risk of enterprises becoming complicit in bribery, bribe solicitation and extortion.

3. Prohibit or discourage, in internal company controls, ethics and compliance programmes or measures, the use of small facilitation payments, which are generally illegal in the countries where they are made, and, when such payments are made, accurately record these in books and financial records.

4. Ensure, taking into account the particular bribery risks facing the enterprise, properly documented due diligence pertaining to the hiring, as well as the appropriate and regular oversight of agents, and that remuneration of agents is appropriate and for legitimate services only. Where relevant, a list of agents engaged in connection with transactions with public bodies 
and State-owned enterprises should be kept and made available to competent authorities, in accordance with applicable public disclosure requirements.

5. Enhance the transparency of their activities in the fight against bribery, bribe solicitation and extortion. Measures could include making public commitments against bribery, bribe solicitation and extortion, and disclosing the management systems and the internal controls, ethics and compliance programmes or measures adopted by enterprises in order to honour these commitments. Enterprises should also foster openness and dialogue with the public so as to promote its awareness of and co-operation with the fight against bribery, bribe solicitation and extortion.

6. Promote employee awareness of and compliance with company policies and internal controls, ethics and compliance programmes or measures against bribery, bribe solicitation and extortion through appropriate dissemination of such policies, programmes or measures and through training programmes and disciplinary procedures.

7. Not make illegal contributions to candidates for public office or to political parties or to other political organisations. Political contributions should fully comply with public disclosure requirements and should be reported to senior management.

\section{Consumer Interests}

When dealing with consumers, enterprises should act in accordance with fair business, marketing and advertising practices and should take all reasonable steps to ensure the quality and reliability of the goods and services that they provide. In particular, they should:

1. Ensure that the goods and services they provide meet all agreed or legally required standards for consumer health and safety, including those pertaining to health warnings and safety information.

2. Provide accurate, verifiable and clear information that is sufficient to enable consumers to make informed decisions, including information on the prices and, where appropriate, content, safe use, environmental attributes, maintenance, storage and disposal of goods and services. Where feasible this information should be provided in a manner that facilitates consumers' ability to compare products.

3. Provide consumers with access to fair, easy to use, timely and effective non-judicial dispute resolution and redress mechanisms, without unnecessary cost or burden.

4. Not make representations or omissions, nor engage in any other practices, that are deceptive, misleading, fraudulent or unfair.

5. Support efforts to promote consumer education in areas that relate to their business activities, with the aim of, inter alia, improving the ability of consumers to: $i$ ) make informed decisions involving complex goods, services and markets, ii) better understand the economic, environmental and social impact of their decisions and iii) support sustainable consumption.

6. Respect consumer privacy and take reasonable measures to ensure the security of personal data that they collect, store, process or disseminate.

7. Co-operate fully with public authorities to prevent and combat deceptive marketing practices (including misleading advertising and commercial fraud) and to diminish or prevent serious 
$\mathrm{C} / \mathrm{MIN}(2011) 11$

threats to public health and safety or to the environment deriving from the consumption, use or disposal of their goods and services.

8. Take into consideration, in applying the above principles, $i$ ) the needs of vulnerable and disadvantaged consumers and ii) the specific challenges that e-commerce may pose for consumers.

\section{Science and Technology}

Enterprises should:

1. Endeavour to ensure that their activities are compatible with the science and technology (S\&T) policies and plans of the countries in which they operate and as appropriate contribute to the development of local and national innovative capacity.

2. Adopt, where practicable in the course of their business activities, practices that permit the transfer and rapid diffusion of technologies and know-how, with due regard to the protection of intellectual property rights.

3. When appropriate, perform science and technology development work in host countries to address local market needs, as well as employ host country personnel in an S\&T capacity and encourage their training, taking into account commercial needs.

4. When granting licenses for the use of intellectual property rights or when otherwise transferring technology, do so on reasonable terms and conditions and in a manner that contributes to the long term sustainable development prospects of the host country.

5. Where relevant to commercial objectives, develop ties with local universities, public research institutions, and participate in co-operative research projects with local industry or industry associations.

\section{Competition}

Enterprises should:

1. Carry out their activities in a manner consistent with all applicable competition laws and regulations, taking into account the competition laws of all jurisdictions in which the activities may have anti-competitive effects.

2. Refrain from entering into or carrying out anti-competitive agreements among competitors, including agreements to:
a) fix prices;
b) make rigged bids (collusive tenders);
c) establish output restrictions or quotas; or
d) share or divide markets by allocating customers, suppliers, territories or lines of commerce.

3. Co-operate with investigating competition authorities by, among other things and subject to applicable law and appropriate safeguards, providing responses as promptly and completely as 
practicable to requests for information, and considering the use of available instruments, such as waivers of confidentiality where appropriate, to promote effective and efficient co-operation among investigating authorities.

4. Regularly promote employee awareness of the importance of compliance with all applicable competition laws and regulations, and, in particular, train senior management of the enterprise in relation to competition issues.

\section{Taxation}

1. It is important that enterprises contribute to the public finances of host countries by making timely payment of their tax liabilities. In particular, enterprises should comply with both the letter and spirit of the tax laws and regulations of the countries in which they operate. Complying with the spirit of the law means discerning and following the intention of the legislature. It does not require an enterprise to make payment in excess of the amount legally required pursuant to such an interpretation. Tax compliance includes such measures as providing to the relevant authorities timely information that is relevant or required by law for purposes of the correct determination of taxes to be assessed in connection with their operations and conforming transfer pricing practices to the arm's length principle.

2. Enterprises should treat tax governance and tax compliance as important elements of their oversight and broader risk management systems. In particular, corporate boards should adopt tax risk management strategies to ensure that the financial, regulatory and reputational risks associated with taxation are fully identified and evaluated. 
$\mathrm{C} / \mathrm{MIN}(2011) 11$

\title{
AMENDMENT OF THE DECISION OF THE COUNCIL ON THE OECD GUIDELINES FOR MULTINATIONAL ENTERPRISES [C(2000)96/FINAL]
}

\author{
THE COUNCIL,
}

Having regard to the Convention on the Organisation for Economic Co-operation and Development of 14th December 1960;

Having regard to the OECD Declaration on International Investment and Multinational Enterprises (the "Declaration"), in which the Governments of adhering countries ("adhering countries") jointly recommend to multinational enterprises operating in or from their territories the observance of Guidelines for Multinational Enterprises (the "Guidelines");

Recognising that, since operations of multinational enterprises extend throughout the world, international co-operation on issues relating to the Declaration should extend to all countries;

Having regard to the Terms of Reference of the Investment Committee, in particular with respect to its responsibilities for the Declaration [C(84)171(Final), renewed in $\mathrm{C} / \mathrm{M}(95) 21]$;

Considering the Report on the First Review of the 1976 Declaration [C(79)102(Final)], the Report on the Second Review of the Declaration [C/MIN(84)5(Final)], the Report on the 1991 Review of the Declaration [DAFFE/IME(91)23], and the Report on the 2000 Review of the Guidelines;

Having regard to the Second Revised Decision of the Council of June 1984 [C(84)90], amended June 1991 [C/MIN(91)7/ANN1] and repealed on 27 June 2000 [C(2000)96/FINAL];

Considering it desirable to enhance procedures by which consultations may take place on matters covered by these Guidelines and to promote the effectiveness of the Guidelines;

On the proposal of the Investment Committee:

DECIDES:

\section{National Contact Points}

1. Adhering countries shall set up National Contact Points to further the effectiveness of the Guidelines by undertaking promotional activities, handling enquiries and contributing to the resolution of issues that arise relating to the implementation of the Guidelines in specific instances, taking account of the attached procedural guidance. The business community, worker organisations, other nongovernmental organisations and other interested parties shall be informed of the availability of such facilities.

2. National Contact Points in different countries shall co-operate if such need arises, on any matter related to the Guidelines relevant to their activities. As a general procedure, discussions at the national level should be initiated before contacts with other National Contact Points are undertaken.

3. National Contact Points shall meet regularly to share experiences and report to the Investment Committee. 
4. Adhering countries shall make available human and financial resources to their National Contact Points so that they can effectively fulfil their responsibilities, taking into account internal budget priorities and practices.

\section{The Investment Committee}

1. The Investment Committee ("the Committee") shall periodically or at the request of an adhering country hold exchanges of views on matters covered by the Guidelines and the experience gained in their application.

2. The Committee shall periodically invite the Business and Industry Advisory Committee to the OECD (BIAC), and the Trade Union Advisory Committee to the OECD (TUAC) (the "advisory bodies"), OECD Watch, as well as other international partners to express their views on matters covered by the Guidelines. In addition, exchanges of views with them on these matters may be held at their request.

3. The Committee shall engage with non-adhering countries on matters covered by the Guidelines in order to promote responsible business conduct worldwide in accordance with the Guidelines and to create a level playing field. It shall also strive to co-operate with non-adhering countries that have a special interest in the Guidelines and in promoting their principles and standards.

4. The Committee shall be responsible for clarification of the Guidelines. Parties involved in a specific instance that gave rise to a request for clarification will be given the opportunity to express their views either orally or in writing. The Committee shall not reach conclusions on the conduct of individual enterprises.

5. The Committee shall hold exchanges of views on the activities of National Contact Points with a view to enhancing the effectiveness of the Guidelines and fostering functional equivalence of National Contact Points.

6. In fulfilling its responsibilities for the effective functioning of the Guidelines, the Committee shall take due account of the attached procedural guidance.

7. The Committee shall periodically report to the Council on matters covered by the Guidelines. In its reports, the Committee shall take account of reports by National Contact Points and the views expressed by the advisory bodies, OECD Watch, other international partners and non-adhering countries as appropriate.

8. The Committee shall, in co-operation with National Contact Points, pursue a proactive agenda that promotes the effective observance by enterprises of the principles and standards contained in the Guidelines. It shall, in particular, seek opportunities to collaborate with the advisory bodies, OECD Watch, other international partners and other stakeholders in order to encourage the positive contributions that multinational enterprises can make, in the context of the Guidelines, to economic, environmental and social progress with a view to achieving sustainable development, and to help them identify and respond to risks of adverse impacts associated with particular products, regions, sectors or industries.

\section{Review of the Decision}

This Decision shall be periodically reviewed. The Committee shall make proposals for this purpose. 
$\mathrm{C} / \mathrm{MIN}(2011) 11$

\section{Procedural Guidance}

\section{National Contact Points}

The role of National Contact Points (NCPs) is to further the effectiveness of the Guidelines. NCPs will operate in accordance with core criteria of visibility, accessibility, transparency and accountability to further the objective of functional equivalence.

\section{A. Institutional Arrangements}

Consistent with the objective of functional equivalence and furthering the effectiveness of the Guidelines, adhering countries have flexibility in organising their NCPs, seeking the active support of social partners, including the business community, worker organisations, other non-governmental organisations, and other interested parties.

Accordingly, the National Contact Points:

1. Will be composed and organised such that they provide an effective basis for dealing with the broad range of issues covered by the Guidelines and enable the NCP to operate in an impartial manner while maintaining an adequate level of accountability to the adhering government.

2. Can use different forms of organisation to meet this objective. An NCP can consist of senior representatives from one or more Ministries, may be a senior government official or a government office headed by a senior official, be an interagency group, or one that contains independent experts. Representatives of the business community, worker organisations and other non-governmental organisations may also be included.

3. Will develop and maintain relations with representatives of the business community, worker organisations and other interested parties that are able to contribute to the effective functioning of the Guidelines.

\section{B. Information and Promotion}

The National Contact Point will:

1. Make the Guidelines known and available by appropriate means, including through on-line information, and in national languages. Prospective investors (inward and outward) should be informed about the Guidelines, as appropriate.

2. Raise awareness of the Guidelines and their implementation procedures, including through cooperation, as appropriate, with the business community, worker organisations, other nongovernmental organisations, and the interested public.

3. Respond to enquiries about the Guidelines from:

a) Other National Contact Points;

b) The business community, worker organisations, other non-governmental organisations and the public; and

c) Governments of non-adhering countries. 
C/MIN(2011)11

\section{Implementation in Specific Instances}

The National Contact Point will contribute to the resolution of issues that arise relating to implementation of the Guidelines in specific instances in a manner that is impartial, predictable, equitable and compatible with the principles and standards of the Guidelines. The NCP will offer a forum for discussion and assist the business community, worker organisations, other non-governmental organisations, and other interested parties concerned to deal with the issues raised in an efficient and timely manner and in accordance with applicable law. In providing this assistance, the NCP will:

1. Make an initial assessment of whether the issues raised merit further examination and respond to the parties involved.

2. Where the issues raised merit further examination, offer good offices to help the parties involved to resolve the issues. For this purpose, the NCP will consult with these parties and where relevant:

a) Seek advice from relevant authorities, and/or representatives of the business community, worker organisations, other non-governmental organisations, and relevant experts;

b) Consult the NCP in the other country or countries concerned;

c) Seek the guidance of the Committee if it has doubt about the interpretation of the Guidelines in particular circumstances;

d) Offer, and with the agreement of the parties involved, facilitate access to consensual and non-adversarial means, such as conciliation or mediation, to assist the parties in dealing with the issues.

3. At the conclusion of the procedures and after consultation with the parties involved, make the results of the procedures publicly available, taking into account the need to protect sensitive business and other stakeholder information, by issuing:

a) A statement when the NCP decides that the issues raised do not merit further consideration. The statement should at a minimum describe the issues raised and the reasons for the NCP's decision.

b) A report when the parties have reached agreement on the issues raised. The report should at a minimum describe the issues raised, the procedures the NCP initiated in assisting the parties and when agreement was reached. Information on the content of the agreement will only be included insofar as the parties involved agree thereto.

c) A statement when no agreement is reached or when a party is unwilling to participate in the procedures. This statement should at a minimum describe the issues raised, the reasons why the NCP decided that the issues raised merit further examination and the procedures the NCP initiated in assisting the parties. The NCP will make recommendations on the implementation of the Guidelines as appropriate, which should be included in the statement. Where appropriate, the statement could also include the reasons that agreement could not be reached.

The NCP will notify the results of its specific instance procedures to the Committee in a timely manner. 
$\mathrm{C} / \mathrm{MIN}(2011) 11$

4. In order to facilitate resolution of the issues raised, take appropriate steps to protect sensitive business and other information and the interests of other stakeholders involved in the specific instance. While the procedures under paragraph 2 are underway, confidentiality of the proceedings will be maintained. At the conclusion of the procedures, if the parties involved have not agreed on a resolution of the issues raised, they are free to communicate about and discuss these issues. However, information and views provided during the proceedings by another party involved will remain confidential, unless that other party agrees to their disclosure or this would be contrary to the provisions of national law.

5. If issues arise in non-adhering countries, take steps to develop an understanding of the issues involved, and follow these procedures where relevant and practicable.

\section{Reporting}

1. Each NCP will report annually to the Committee.

2. Reports should contain information on the nature and results of the activities of the NCP, including implementation activities in specific instances.

\section{Investment Committee}

1. The Committee will consider requests from NCPs for assistance in carrying out their activities, including in the event of doubt about the interpretation of the Guidelines in particular circumstances.

2. The Committee will, with a view to enhancing the effectiveness of the Guidelines and to fostering the functional equivalence of NCPs:

a) Consider the reports of NCPs.

b) Consider a substantiated submission by an adhering country, an advisory body or OECD Watch on whether an NCP is fulfilling its responsibilities with regard to its handling of specific instances.

c) Consider issuing a clarification where an adhering country, an advisory body or OECD Watch makes a substantiated submission on whether an NCP has correctly interpreted the Guidelines in specific instances.

d) Make recommendations, as necessary, to improve the functioning of NCPs and the effective implementation of the Guidelines.

e) Co-operate with international partners.

f) Engage with interested non-adhering countries on matters covered by the Guidelines and their implementation.

3. The Committee may seek and consider advice from experts on any matters covered by the Guidelines. For this purpose, the Committee will decide on suitable procedures.

4. The Committee will discharge its responsibilities in an efficient and timely manner. 
5. In discharging its responsibilities, the Committee will be assisted by the OECD Secretariat, which, under the overall guidance of the Investment Committee, and subject to the Organisation's Programme of Work and Budget, will:

a) serve as a central point of information for $\mathrm{NCPs}$ that have questions on the promotion and implementation of the Guidelines;

b) collect and make publicly available relevant information on recent trends and emerging practices with regard to the promotional activities of NCPs and the implementation of the Guidelines in specific instances. The Secretariat will develop unified reporting formats to support the establishment and maintenance of an up-to-date database on specific instances and conduct regular analysis of these specific instances;

c) facilitate peer learning activities, including voluntary peer evaluations, as well as capacity building and training, in particular for NCPs of new adhering countries, on the implementation procedures of the Guidelines such as promotion and the facilitation of conciliation and mediation;

d) facilitate co-operation between NCPs where appropriate; and

e) promote the Guidelines in relevant international forums and meetings and provide support to NCPs and the Committee in their efforts to raise awareness of the Guidelines among nonadhering countries. 
COUNCIL

English - Or. English

\section{Council}

REVISED RESOLUTION OF THE COUNCIL

ON A NEW GOVERNANCE STRUCTURE FOR THE ORGANISATION

This revision of Chapters 3 and 4 of the Annex to the Resolution C(2006)78/FINAL was adopted by unanimity by the Council at its 1234th session on 16 December 2010 [C(2010)140 and C/M(2010)24, Item 282].

JT03296301

Document complet disponible sur OLIS dans son format d'origine

Complete document available on OLIS in its original format 


\section{THE COUNCIL,}

Having regard to the Convention on the Organisation for Economic Co-operation and Development of 14 December 1960;

Having regard to the reforms undertaken and the proposals submitted since 2001, and in particular the "Julin Report" on Future Direction of the OECD: Report on OECD's Role in Global Architecture [HOD(2003)2], the "Noboru Report" on A Strategy for Enlargement and Outreach [C(2004)60], and the latest Report by the Secretary-General on Reform [C/MIN(2005)9];

Having regard to the Council conclusions of 22 April and 6 May 2004 on the OECD Reform [C/M(2004)10, Item 143 and C/M(2004)11, Item 153];

Having regard to the Council Resolution of 21 July 2005 establishing a Council Working Party on implications of future enlargement on OECD governance [C(2005)100 and C/M(2005)17, Item 214];

Having regard to the Report by the Technical Task Force on Cost Implications of Enlargement [C(2005)87] presented to Council on 21 July 2005 [C/M(2005)17, Item 218] and on 23 November 2005 [C/M(2005)22, Item 295];

Having regard to the Report by the Working Party on the Implications of Future Enlargement on OECD Governance [C/WPEG(2006)10] agreed on 21 April 2006;

\section{DECIDES:}

1. The Report by the Working Party on the Implications of Future Enlargement on OECD Governance, set out in the Annex hereto and forming an integral part of this Resolution, is adopted by unanimity.

2. The Secretary-General is invited to take the appropriate action for a full implementation of this Resolution.

3. This Resolution enters into force on 1 June $2006{ }^{*}$

A number of amendments to Chapters 3 and 4 of the Annex to the Resolution C(2006)78/FINAL were unanimously adopted by Council on 16 December 2010 [C(2010)140 and C/M(2010)24, Item 282]. This revised Resolution [C(2006)78/REV1/FINAL] entered into force on 1 January 2011. 
C(2006)78/REV1/FINAL

\begin{abstract}
ANNEX
[as amended by the Decision of the Council of 16 December 2010 $\mathrm{C}(2010) 140 ; \mathrm{C} / \mathrm{M}(2010) 24$, Item 282]
\end{abstract}

\title{
CHAPTER 1: POLITICAL BACKGROUND
}

1. The Council Working Party on the Implications of Future Enlargement on OECD Governance (WPEG) stemmed from the need perceived by Members to prepare the Organisation for enlargement. Enlargement itself is considered important by all of the Member countries in order to affirm the Organisation's global nature and its relevance in the architecture of international organisations.

2. A number of reports have already been prepared by eminent authors, such as the Nicholson [SG(2003)1], Julin [HOD(2003)2] and Noboru [C(2004)60] reports, and they remain fully relevant. The WPEG's objective is therefore to build on the results of past efforts and on discussions that have taken place between September and December 2005, in order to arrive at specific decisions for improving governance so that the OECD may embark upon a real policy of enlargement.

\section{Future role and direction}

3. Important discussions have taken place on the future role and direction of our Organisation. These discussions, conducted by Ambassador Gun-Britt Andersson, have made clear that there is broad agreement among our respective national perceptions of the OECD's future role.

4. Her report [C/WPEG(2005)3/REV1] is based on the intentions of the founders of the Organisation, on the Convention, on changes in the world since 1960 and on the OECD's strengths and weaknesses in the architecture of international organisations, so as to reaffirm what is essential - the future role and direction of our Organisation through such means as:

i) advising Member countries concerning their economic and structural policies;

ii) sharing with non-Members the good policies arising from internal deliberations;

iii) participating in the formulation of standards and good practices at the international level;

iv) promoting economic growth and development and helping to solve problems having a global dimension.

5. The Organisation for Economic Cooperation and Development and its Member countries have succeeded in striking a good balance between two different objectives: on the one hand, the service to Member countries, by helping them to identify the most important issues of their economic development and to define sustainable national policies and by developing advice and peer reviews on structural policies and, on the other hand, the engagement with non-Members, in particular large emerging economies, to share best practices and to promote economic development.

6. During the important discussions on the future role and direction of the OECD, all Members confirmed their commitment to the current working method of substantive committees and peer reviews, to advising governments and to reaching out to non-Members. All Members confirmed their attachment to an Organisation with a diverse membership, in a spirit of mutual respect. 
7. The OECD is highly relevant to Member countries and ready to engage resolutely and positively with other participants in the world economy, both large and small.

\section{CHAPTER 2: THE GOVERNANCE STRUCTURE OF THE OECD}

\section{The Convention}

8. The Convention establishing the OECD remains relevant and pertinent and provides all the latitude required to adjust the Organisation's institutional mechanisms to its needs now and after enlargement.

\section{The Council}

9. Council is the highest body of the OECD. It has been entrusted by the Convention to be the body from which all acts of the Organisation derive. Council, at the level of Ministers as well as Permanent Representatives representing a whole-of-government view, is the appropriate forum for shaping the future direction of the Organisation, for discussing and deciding key policy issues, and for taking decisions involving obligations of Members. Council is the relevant forum for policy exchanges with the SecretaryGeneral in his capacity as Chair.

10. As specified in the Convention, each Member country "has one vote" and the European Commission "shall take part in the work of the OECD". In Council, decisions by mutual agreement are the rule, except for special cases. Council meetings shall normally be held once a month at the level of Permanent Representatives. The Council concentrates on policy and strategic issues.

\section{Meetings of Heads of Delegation}

11. Informal meetings of Heads of Delegation are highly useful, especially for exchanging views without instructions, bringing views closer together, testing new projects, informally preparing sensitive decisions such as appointing the institution's senior managers (according to Article 10 of the Convention) or preparing annual Ambassadors' seminars. These meetings will remain informal and be few in number.

\section{The Secretary-General}

12. In accordance with Article 10 of the Convention, the Secretary-General is responsible to the Council. He/she chairs the sessions of the Council at the level of Permanent Representatives.

13. Without prejudice of future decisions by Council, the proposed new structure of governance does not alter the current division of responsibilities between the Council and the Secretary-General. ${ }^{1}$

14. The Secretary-General carries policy, executive and management responsibilities. He/she also represents the Organisation vis-à-vis the rest of the world and acts as its legal representative. He/she may submit proposals, including the Programme of Work and Budget, to the Council and to any other body of the Organisation. He/she is in charge of executing the Council decisions and implementing the PWB. $\mathrm{He} / \mathrm{she}$ ensures that the Organisation's activities are managed within the Budget in a cost effective manner.

1. See Note C/WPEG(2006)6 by the Secretariat on "The Responsibilities of the Secretary-General" dated 14 March 2006. 
15. At present, the Secretary-General meets informally with the Chairs of committees and working groups directly subsidiary to the Council. These informal meetings have no decision-making power, no summary records and no specific timetable. It belongs to the sphere of authority of the Secretary-General, as the Chair of the Council, to decide how he/she intends to exercise his mandate and how he/she wants to organise consultations.

\section{Substantive committees}

16. Through its committee structure the OECD's substantive policy agenda and outputs respond directly to the needs of, and are closely monitored by, senior policy officials from capitals in a way that may be unique among international organisations. It is these committees that produce the outputs of the OECD, the policy advice, guidelines, principles ("soft law") and best practices. The working methods of the committees are one of the institution's hallmarks, the source of its added value and the support it enjoys in capitals. It is therefore essential for the future of the OECD that these working methods be able to continue producing quality output after enlargement. The Noburu report covered this topic capably and at length.

17. We too must recognise, as did the Report, that each substantive committee would like to tailor its working methods to its own needs. Here, then, it is important not to want to shackle committees too tightly by imposing on them a single working method.

18. Decisions of substantive committees will continue to follow current practices, unless otherwise agreed by Council.

\section{Relations between the Council and substantive committees}

19. Ambassador Véronique Ingram's report to WPEG [C/WPEG/SG(2006)1/FINAL] makes several proposals to streamline the relations between Council and substantive committees. These proposals were discussed in WPEG and should serve as a base for improved relations between the two levels of governance. For example, the following lines should be implemented:

Dialogues between the Council and each Committee Chair should be held at least once every biennium. On this occasion, Committee Chairs and the relevant Director should outline their priorities and modus operandi for the next 12 months, report on their performance against the PWB in respect of their achievement of expected outputs, and advise on their governance arrangements (composition and election of bureaus and their role vis--à-vis the committees). Prior to the dialogue session with Council, standardised documentation will be made available to Members of the Council by the Directorate involved, along the lines proposed by Ambassador Véronique Ingram in her report. The annual reports, transmitted by substantive Committees to the Budget Committee on their implementation of the PWB, are also a part of the dialogue between the Committees and the Council.

$>$ The recent experience of dialogues between the Council and Chairs of substantive committees shows interesting improvements, with Heads of Delegation volunteering to prepare the detail of each dialogue with Chairs of committees. These improvements should be encouraged and further deepened.

$>$ Chairs and members of the substantive committee bureaus should be selected by mutual agreement through a transparent and fair process, on the basis of merit and for a specified duration; their role and duties should be set out by the committees. 
The Secretary-General will submit to Council for approval, as soon as possible, a revised version of the handbook for Committee Chairs taking into account the elements referred to above.

\section{Written procedures and oral reports}

20. Written procedure should be used more frequently. Such a procedure would provide for written questioning of the Delegations, seven-day deadlines for reaction, and final decision if no Member interrupts the procedure within the specified amount of time. In the case of an interruption of the procedure by a Member, the decision making procedure resumes at the stage and in the body it had reached before. Such a written procedure could be justified by urgency (since the Council would meet less often) or by the mere fact that the proposed decision has gathered broad consensus at a subordinate level.

\section{Time and meeting management}

21. Ambassador Hubert Wurth's report [C/WPEG/SG(2006)1/FINAL] underlines the needs for a strict discipline on speaking time for delegation leaders, in Council as well as in other meetings. The experience gained with the rule restricting individual interventions to three minutes is considered by Delegations to be a success

22. Meeting management rules, including those adopted in June 2004 [C(2005)83], should be continuously developed and implemented by the Council and across the Organisation.

23. The documents on which the Council and the standing committees are expected to discuss and decide will be made available at least seven days before the meeting, in both official languages of the Organisation; the Chair will wrap up the debates within the time allocated for a specific issue; the preparatory meetings of the Council will be used to announce preliminary national positions; written procedure will be used more frequently; the electronic discussion groups will be used to share positions between sessions, etc.

24. The Secretary-General is entrusted with the responsibility of implementing these rules and of disseminating them at all levels of governance.

\section{CHAPTER 3: STRUCTURE AND DECISION-MAKING MECHANISMS}

25. The governance structure for the OECD must serve the needs of the Organisation and all its Members, both at present and after enlargement. In this regard, the structure has the following objectives:

- Ensuring that Council has the time to focus on strategic direction by removing non-essential issues from its agenda;

- Improving responsiveness, flexibility, effectiveness and efficiency by delegating and by significantly expanding the use of Qualified Majority Voting (QMV).

\section{Standing Committees}

26. Council operates as the strategic governing body. It is assisted by its standing committees in the preparation of discussions and decisions on substantive issues. Operational issues are handled by its standing committees. The work in these bodies proceeds under the direction of Council, in accordance with the mandates and delegated authorities for each of the standing committees. 
27. There are three plenary standing committees: Executive Committee (ExCo), Budget Committee (BC) and an External Relations Committee (ERC). Each of the three bodies is responsible for a cohesive group of functions and issues.

28. Each standing committee has a Chair and one or two Vice-Chairs to assist her/him. They are elected yearly by mutual agreement through a transparent and fair process. Chairs are elected by the Council, Vice-chairs by their committee. Chairs and Vice-Chairs are eligible for re-election once.

29. Each standing committee decides by mutual agreement how to further organise its work, including the possibility of establishing a bureau.

30. Working groups can be created by mutual agreement by the three standing committees in order to explore specific topics. The mandates of these working groups will be decided by mutual agreement, including their composition, working methods, the scope of their activities and a specific end date. These groups will report to the standing committee that created them. Their membership can be restricted or open-ended. They will only make recommendations to their standing committee.

31. The following outlines the general mandates and overall responsibilities of the three standing committees:

- $\quad$ The Executive Committee (ExCo)

- assists the Council by preparing for its decisions on reports and proposals - including draft Acts of the Organisation and agreements elaborated by the substantive committees or other such specialist bodies;

- advises the Council on preparations and follow-up to Ministerial meetings of OECD bodies; and on committee structures, mandates and evaluation;

- advises the Council on strategic issues and priorities, including those regarding the management and operations of the Organisation, where these fall within the competence of Council and which are not otherwise covered by other standing committees;

- advises the Council on policy issues not covered by the mandates of the other bodies directly subordinate to the Council;

- carries out any functions delegated to it by Council, and reports to it as appropriate.

- $\quad$ The Budget Committee (BC)

- assists and advises the Council in preparing for its discussions and decisions on the budget priorities and envelope and on the biennial Programme of Work and Budget including amendments to the PWB,

- monitors the implementation of the agreed budget, the allocation/reallocation of financial resources and reports to and advises Council on these, as appropriate;

- assists the Council in preparing for discussions and decisions on elements of the integrated management cycle, such as the MTO and the PIR;

- advises the Council on the management of funds and voluntary contributions, the closing of accounts of each financial year and on the Financial Regulations;

- carries out any functions delegated to it by the Council, and reports to it as appropriate. 
- $\quad$ The External Relations Committee (ERC)

- assists the Council in preparing for its discussions and decisions on strategies, policies and guidelines on external relations and relations with non-Members and international organisations, including conditions of their participation in the work of the Organisation;

- monitors the implementation of these decisions and advises the Council;

- advises the Council on the co-ordination of activities and programmes with non-Members:

- assists the Council in ensuring that the global relations of the Organisation are taken into account in the preparation of the PWB;

- carries out any functions delegated to it by Council, and reports to it as appropriate.

\section{Special Bodies}

32. In the past, special bodies, restricted or plenary, were created by Council for a particular substantive, advisory or functional mission. Some of them have been discontinued (e.g. the Informal Group on the Site and the Committee on Public Affairs and Communications). As these special bodies' activities are more focused on specific areas, their interaction with Council, if any, is less intense than is the case between Council and standing committees. These bodies have proven their usefulness and added value.

33. Currently, these are: the Audit Committee, the Pension Budget and Reserve Funds Management Board and the Evaluation Committee.

\section{Mutual agreement and qualified majority}

34. Mutual agreement is the absence of objection by any Member to a draft proposal. Unanimity is the agreement of all Members to a draft proposal.

35. QMV is a mechanism that is used successfully in many international institutions to facilitate reaching agreement. The QMV formula agreed by Council in 2004 allows for decisions to be taken if supported by $60 \%$ of Member countries, unless opposed by three or more members who represent at least $25 \%$ of the Part I scale of contributions.

36. The application of QMV involves a process of several steps. The Chair will first make every effort to reach mutual agreement. If unable to reach mutual agreement, the Chair will call for a short pause for reflection and will set a final date for reaching a decision. If mutual agreement is still not achieved by that time, the Chair will call for a vote by QMV.

\section{Categories of cases}

\section{The normal cases}

37. All issues will follow the normal cases procedure, except fundamental cases, special cases and delegated cases, as explained below.

38. The decisions on "normal cases" will be made by mutual agreement at the Council level, after preparation in the standing committees. 
39. "A" points are those items prepared by bodies directly subsidiary to the Council and likely to be adopted without debate, mentioned in each Council session agenda. They follow the procedure as set out below.

40. The Chairs of the standing committees will prepare draft decisions and, in most cases, will send the proposed decisions to the Council as "a" points. They should send the draft decision to the Council as an "a" point only if confident that it enjoys broad and substantial support of the Members. Once on the Council agenda as an "a" point, the draft decisions may only be reopened at the request of at least $15 \%$ of the Membership or if any Member country invokes the safeguard mechanism.

41. An "a" point sent to Council will be adopted by mutual agreement unless at least $15 \%$ of the Member countries (rounded up to the nearest unit) request the issue to be re-opened. In this case, the issue will be discussed by Council, which will either adopt a decision by mutual agreement or refer the issue back to the standing committee for further work. The requests to reopen the issue will be made by the Heads of the Delegation before the meeting of Council.

42. The safeguard mechanism: if a very important interest of a Member country is endangered by a draft decision prepared by a standing committee and sent as an "a" point to Council, the Secretary-General, upon written request of that Member, shall call for a special meeting of the Council to address the issue. At this meeting, the Member invoking its national interest will explain the problem and will be expected to suggest a solution. The Council will either adopt a decision by mutual agreement or refer the issue back to the standing committee for further work.

\section{Fundamental cases (see list below)}

43. This category contains those strategic issues that should be addressed by Council and for which decisions should be taken by mutual agreement because some of these issues are highly political in nature, because they create political or legal obligations for Members, because they require a whole-ofmembership perspective or because they involve the overall stewardship of the Organisation. These cases will normally form " $b$ " points on the Council agenda (for discussion and decision by Council) although it is possible for such cases to be presented to Council as "a" points. Decisions on these cases may be prepared by a standing committee, the Secretary-General or some other body, or may first arise in Council itself.

\section{Special cases (see list below)}

44. The Convention (Article 6.1) provides that decisions are taken by mutual agreement of all Members unless the Council unanimously agrees otherwise for special cases.

45. In 2004, the Council decided that the decision-making mechanism for special cases would be QMV, both at the level of Council and in the standing committees. Special cases can either be decided by Council or, if delegated, by standing committees.

46. All decisions taken by a standing committee in application of a delegation by Council to that standing committee will be formally recorded by the Secretary-General.

\section{The Lists of Fundamental, Special, and Delegated Cases}

47. Existing Council decisions which attribute decision-making authority by mutual agreement to standing and substantive committees remain unchanged unless otherwise indicated below or decided in the future by Council. 
C(2006)78/REV1/FINAL

48. The following fundamental cases are decided by Council by mutual agreement or unanimity, and can be prepared by standing committees also by mutual agreement.

i. Approval of the Organisation's governance structures;

ii. Revision of the mandates of standing committees;

iii. Creation of special cases including the cases to be delegated (unanimity is required under Article 6 of the Convention);

iv. Adoption and revision of the Rules of Procedure of the Organisation, including its language regime;

v. Approval of priorities, strategic and budget orientations and policy frameworks;

vi. Adoption and revision of Acts (Decisions, Recommendations) and Agreements under Article 5 of the Convention;

vii. Decision on new membership (unanimity is required under Article 16 of the Convention);

viii. Approval of policy frameworks with respect to relations with non-Members, international organisations, Parliaments and other public authorities and civil society, including academia;

ix. Approval of new invitations and new participation of non-Members in the work of the Organisation;

x. Adoption of the budget envelope, defined as the sum of appropriations financed from assessed contributions and other income, and special budgets;

xi. Approval of supplementary budgets which induce an increase in the assessed contributions of current members/participants;

xii. Approval of the principles and rules on the scales of contributions;

xiii. Closing of annual accounts and discharge to the Secretary-General;

xiv. Decisions on appointments, elections and designations attributed to the Council;

xv. Decisions on the Headquarters (Article 18 of the Convention).

49. The following cases are delegated to the standing committees identified below and are to be decided there by mutual agreement:

(a) Executive Committee:

i. Decisions regarding the implementation of policy frameworks towards civil society.

\section{(b) External Relations Committee:}

i. Decisions regarding the implementation of policy frameworks on relations with non-Members;

ii. Decisions regarding the implementation of policy frameworks on relations with International Organisations.

50. The following special cases are decided by QMV by Council:

i. Creation, continuation and abolition of substantive committees and programmes, including revision of their mandates; 
ii. Adoption and revision of Staff Regulations and Rules;

iii. Adoption and revision of Financial Regulations and related rules;

iv. Decisions implementing the Financial Regulations and related rules (attributed to Council therein), including those concerning modifications to the Programme of Work or to the allocation of resources and the carry forwards of resources;

v. The Organisation's Programme of Work and Budget, within a consensus-agreed budget envelope, and any related decisions which allocate resources down to the Output Area level, with decisions prepared in the Budget committee and taken at Council, both bodies acting on the qualified majority voting basis, if required; ${ }^{2}$

vi. MTO and PIR methodology;

vii. Decisions regarding the Evaluation Committee's recommendations to substantive committees;

viii. Decisions regarding the monitoring of the implementation by substantive committees of the Evaluation Committee's recommendations;

ix. Decisions regarding the follow-up to reports on the implementation of Acts;

x. Decisions to hold sectoral ministerial meetings and decisions regarding their themes and dates. ${ }^{3}$

51. The following special cases are delegated to standing committees identified below, and are decided there by $Q M V$ :

(a) Executive Committee:

i. Decisions implementing CCR recommendations (except methodology and use of the affordability clause);

ii. Decisions regarding the implementation of policy frameworks related to communications and publishing;

iii. Decisions regarding the implementation of policy frameworks related to patronage and sponsorship and OECD centres;

iv. Decisions concerning continuation of subsidiary bodies of substantive committees under Article 21 of the Rules of Procedure.

\section{(b) Budget Committee:}

i. Annual approval of the scales of contributions;

ii. Decisions on the implementation of the Programme of Work and Budget;

2. Cf. the Council decision of 22 April 2004 [C/M(2004)10, Item 143].

3. As well as locations of ministerial meetings other than those of the bodies of the Organisation. 
iii. Decisions implementing the Financial Regulations and related rules (attributed to the Budget Committee therein), including those concerning modifications to the Programme of Work, the reallocation of resources, commitments in a future financial period, commitments in the current financial period for expenditure to be made after the end of that period and the approval of grants and voluntary contributions;

iv. Approval of supplementary budgets which do not induce increases in the assessed contributions of current members/participants;

v. Decisions on the management of the Pension Budget and Reserve Fund.

\section{(c) External Relations Committee:}

i. Decisions on non-Members' fees, after consultation with the Budget Committee; ${ }^{4}$

ii. Decisions on evaluation and renewal of regular observers.

\section{Interpretation regarding classification}

52. Any problem of interpretation on the classification of a specific issue into one of the categories will be prepared by the Executive Committee and decided by Council as a normal case.

\section{Cloture of debates}

53. Chairs will decide on the cloture of debates and will implement the decision-making mechanism, whether mutual agreement or qualified majority, as soon as she/he feels that all arguments have been examined and discussed. It is the prerogative of the Chair to take such a decision. Members may invite the Chair to proceed with the cloture of debates.

\section{CHAPTER 4: REVISION AND IMPLEMENTATION}

\section{Revision Clause}

54. An assessment of the governance system will be conducted no later than four years after entry into force of the revised Resolution or before, if Council so decides. In the meantime, and if necessary, moving a specific issue from the delegated to the non-delegated list, from the special cases to the delegated special cases lists or removing an issue from the special cases list will be done by QMV by Council. Moving a fundamental case (paragraph 48) or a delegated case to be decided by mutual agreement (paragraph 49) to another category will require mutual agreement. The creation of new special cases will require unanimity according to Article 6.1 of the Convention.

\section{Implementation}

55. This revised Resolution will enter into force on 1 January 2011.

4. Consultation would concern the level of fees. If, after the consultation with the Budget Committee, views differ, the ERC should advise the BC accordingly and provide it with another opportunity to offer its views before taking the final decision. 


\section{Unclassified}

C/MIN(2007)4/FINAL

Organisation de Coopération et de Développement Economiques

Organisation for Economic Co-operation and Development

16-May-2007

COUNCIL

English/French

COUNCIL RESOLUTION ON ENLARGEMENT AND ENHANCED ENGAGEMENT

(adopted by Council at Ministerial Level on 16 May 2007) 
C/MIN(2007)4/FINAL

Having Regard to the Convention on the Organisation for Economic Co-operation and Development of 14 December 1960, and in particular its articles 1, 2, 5, 12 and 16; Report);

Having Regard to the Report "A strategy for outreach and enlargement" [C(2004)60] (Noboru

Having regard to the "Resolution to establish a mechanism to identify countries for potential accession and countries for enhanced engagement with the OECD" [C(2006)73/FINAL; C/M(2006)9];

Having regard to the mechanism to identify countries for potential accession and countries for enhanced engagement [C(2006)105/REV1];

Having regard to "Enhanced Engagement: Report by the External Relations Committee"[C(2007)42 \& CORR1 \& 2];

Having regard to A General Procedure for future accessions C(2007)31/REV3;

Recognising the need to further expand the OECD's global reach, policy impact and relevance,

\section{ON ENLARGEMENT AND ENHANCED ENGAGEMENT}

\section{THE COUNCIL}

i) Invites the Secretary-General to strengthen OECD co-operation with Brazil, China, India, Indonesia and South Africa through enhanced engagement programs with a view to possible membership. The Council will determine whether to open discussions on membership in light of the willingness, preparedness and ability of these countries to adopt OECD practices, policies and standards.

ii) Decides to open discussions with Chile, Estonia, Israel, the Russian Federation and Slovenia and invites the Secretary-General to set out the terms, conditions and process for the accession of each of these countries to the OECD for subsequent consideration and adoption by Council. Separately, Council may raise issues of a political nature which the Secretary-General will convey to the countries concerned in the context of the discussions on accession.

iii) Invites the Secretary-General to inform other countries that have applied for membership that their applications for accession shall be further considered individually by Council as enlargement proceeds; future applications shall be similarly considered.

iv) Invites the Secretary-General to explore and develop recommendations to Council on how to expand the OECD's relations, including through enhanced engagement, with selected countries and regions of strategic interest to the OECD, identified by Council. In light of its growing importance in the world economy, priority will be given to South East Asia with a view to identifying countries for possible membership. 
v) Invites the Secretary-General to report regularly to the Council on the progress of his discussions and consultations with the countries above and outline options for the OECD's further relationship with these countries. In outlining such options, due consideration will be given to the capacity of the Organisation to process potential candidates without affecting the regular programme of work.

\section{ON FINANCING}

THE COUNCIL AGREES TO THE FOLLOWING:

i) As a result of enlargement, the financing of the OECD needs to be reformed. In the transition, an interim approach will be required.

ii) During this interim period, upon joining the OECD, new Members would pay an annual amount to cover their costs, including transition costs, arising from their participation in the activities covered by the Part I budget of the Organisation. This amount would range from 2.4 to 5.7 Million Euros, which would be paid annually until a reform of financing of the Organisation for all Members has been fully implemented. This range only applies to new Members and is without prejudice to any future decisions on financing. The precise amounts to be paid by each new Member will be agreed before the adoption of the first "roadmap" for accession and will be adjusted in line with the level of adjustment of the Part I budget and in the light of the reform of financing to be agreed.

iii) Members commit to undertake a reform that will ensure that the OECD will have a strong and sustainable financial foundation. The reform will address burden sharing, while recognising the diversity of the membership, and would be implemented progressively over a period of up to 10 years with adequate mitigation measures. The objective of the reform would be that each Member will cover most, if not all, of the costs of its participation in the Part I budget of the Organisation. The amount of these costs remains to be determined, while recognising that country specific costs could be different. Members' total contributions would then reflect both recurrent costs of their membership and capacity to pay.

iv) Council shall reach agreement on this reform before the $2008 \mathrm{MCM}$. 


\section{Unclassified}

C(2004)132/FINAL

Organisation de Coopération et de Développement Economiques

Organisation for Economic Co-operation and Development

05-Aug-2004

COUNCIL

English - Or. English

\section{Council}

RESOLUTION OF THE COUNCIL CONCERNING THE PARTICIPATION OF NON-MEMBERS IN THE WORK OF SUBISIDARY BODIES OF THE ORGANISATION

(adopted by the Council at its 1091st Session on 8 July 2004) 


\section{THE COUNCIL,}

Having regard to the Convention on the Organisation for Economic Co-operation and Development of 14th December 1960, and in particular to its Article 12;

Having regard to the Rules of Procedure of the Organisation, and in particular to Articles 8 to 10 thereof, which provide that a non-Member government may be invited to be represented as an observer at meetings, or parts of meetings of bodies of the Organisation, or to participate more fully in the activities of the Organisation;

Having regard to the conclusions of the Council on the Strategy for Enlargement and Outreach;

Recognising that non-Member economies, hereafter referred to as non-Members, can fulfil an important role in enhancing the quality of the Organisation's work, and its influence on shaping the international economic order and thus its capacity to fulfil its mandate as defined in the OECD Convention;

Recognising further the increased global interdependence rendering the prosperity of Member countries conditional not only on the development of their own economies, but on global economic development;

Resolved to share OECD's policy practices with non-Members with a view to the diffusion and promotion of the values of the Organisation (dissemination), as well as to these policy practices more relevant and globally acceptable through the participation of non-Members both in their development and in their implementation (participation);

Mindful, therefore, of the importance for the Organisation of maintaining and intensifying a dialogue with non-Members through the conscious and strategic application of the available forms of cooperation;

Mindful, as well, of the impact participation of non-Members may have on the functional processes of the Organisation, including their specific application in individual subsidiary bodies, and of the limits for the engagement of non-Members imposed by resource constraints requiring a focused strategy to maximise the effectiveness and benefit of outreach;

Noting that the question of participation of non-Members in the activities of a subsidiary body of the Organisation must be considered in accordance with the overall outreach strategy of the Organisation;

Noting the important role that participation by non-Members in the work of the Organisation can also play in preparing selected non-Members for possible future membership in the OECD within the framework of the Programme for Partners with Accession Perspective;

Noting the need for a sound and systematic basis for the assessment and effective management of non-Member engagement;

Noting, as well, the need throughout the Organisation for oversight and guidance on the policies and practices applicable to the invitation process and to the subsequent participation of non-Members in its work;

\section{DECIDES:}


1. The initiative to launch the procedure leading to an invitation to a non-Member to participate in subsidiary bodies lies with the Organisation.

2. The Council may decide on its own initiative, on the advice of the CCN, to invite selected nonMembers to participate in one or several subsidiary bodies within the framework of the Organisation's overall outreach or enlargement strategies. Council will consult with the relevant Committee(s) before taking a decision.

3. A Committee may take the initiative to recommend to the Council via the $\mathrm{CCN}$ to invite a nonMember after developing, in line with its mandate and the Organisation's overall outreach strategy, a welltargeted, pro-active outreach strategy which provides a framework for the participation of non-Members in the work of the Committee and its subsidiary bodies. In order to identify the non-Members to be invited and the appropriate form of participation, the strategy should consider the elements set out in Annex I.

4. Non-Members may also express their own interest in participating in the work of a subsidiary body. Expressions of interest originating from a non-Member shall be brought to the attention of the CCN who will recommend to Council, in light of the Organisation's overall outreach strategy, after consulting with the relevant Committee, an appropriate course of action.

5. The Council, assisted by the CCN, shall assess recommendations by Committees in light of the Organisation's overall strategy towards the non-Members concerned. The Council shall retain the final decision on the invitation of non-Members to participate as regular observers or full participants in subsidiary bodies.

6. In accordance with the Committee's outreach strategy, a Committee or one of its subsidiary bodies may invite non-Members to be represented by an ad hoc observer at particular meetings or parts thereof at its discretion. The Secretariat shall keep the CCN regularly informed of such proposed invitations. The Council retains the right to intervene on the extension of such invitations.

7. Monitoring of non-Member participation shall take place on an annual basis in the form of Committee Chairs reporting to the CCN.

8. Evaluations should be undertaken and reported to the $\mathrm{CCN}$ Chair prior to any recommendations by the $\mathrm{CCN}$ to the Council on the renewal of an invitation to participate.

9. Renewal shall be formally agreed by the Council based on an assessment of the benefits of the participation of the non-Member. Criteria for renewal shall include:

a) quality of participation;

b) annual compliance with financial obligations;

c) continuing consistency with the outreach strategy;

d) impact on the efficient functioning of the Committee.

10. The process described above shall be as expeditious as possible. Where justified by circumstances, a written procedure may be followed by the Council and the concerned subsidiary bodies.

11. Annex I and II form an integral part of this Resolution. Annex II contains guidelines of general application for subsidiary bodies regarding the invitation process and the subsequent participation of invited non-Members in their work. The Council may provide different guidance in specific cases. 
C(2004)132/FINAL

12. This Resolution replaces Resolution C(96)64/REV2/FINAL. 
C(2004)132/FINAL

\section{ANNEX 1 \\ GUIDELINES FOR SUBSIDIARY BODIES ON THE DEVELOPMENT OF A PRO-ACTIVE STRATEGY FOR THE PARTICIPATION OF NON-MEMBERS}

Committees shall develop, in line with their mandates, and the Organisation's overall outreach strategy, a pro-active outreach strategy for the participation of non-Members in the work of the Committee and its subsidiary bodies. The strategy should consider the following elements in order to identify the nonMembers to be invited and the appropriate form of participation:

a) whether non-Member participation would facilitate appreciably the achievement of the mandate and the programme of work of the subsidiary body concerned;

b) whether and in what ways association of non-Members with its work would be of benefit to the Organisation including in fulfilling its mandate of contributing to the development of nonMembers.

c) whether economic growth and/or the welfare of Members, considered on a national, regional or global basis ${ }^{1}$, within the substantive area covered by the subsidiary body concerned are influenced to a significant degree by the policy orientations of non-Members;

d) in relation to the substantive area covered by the mandate of the subsidiary body concerned, the degree to which non-Members' institutional and policy know-how contributes significantly to OECD peer learning/influencing and rule-making processes;

e) the appropriate number of non-Member participants, focusing both on the non-Members and the time period of the invitations in light of the requirements of the mandate of the subsidiary body concerned, its programme of work and its methods of work;

f) the consequences that non-Members' participation might have on the working methods, programme of work and Secretariat resources devoted to the subsidiary body concerned;

g) in the case of full participants, the non-Member has been found to be willing and able to commit to the relevant OECD acquis, as appropriate;

h) a consideration of the full range of vehicles to engage non-Members in the work of the Organisation and the subsidiary body concerned, as well as the limits and forms of the

The impact of a non-Member's policies on an individual OECD Member state, or indeed on a region, should not be of itself sufficient justification for that non-Member's participation in an OECD body. National or regional impact should be merely one element in the analysis which Committees go through in drawing up a strategy. 
C(2004)132/FINAL

participation of non-Members which appear desirable and most useful, to maximise the benefits and reduce any disadvantages.

Committees should review their strategy regularly in light of changes to their mandate or programme of work orientations. 
C(2004)132/FINAL

\section{ANNEX II \\ GUIDELINES ON PARTICIPATION BY NON-MEMBERS IN THE WORK OF SUBSIDIARY BODIES OF THE ORGANISATION}

\section{FORMS OF POSSIBLE CO-OPERATION}

1. In considering the establishment of relations with non-Members, a subsidiary body should examine the full range of possible means of co-operation with that non-Member, with a view to finding those best suited to the Organisation and the non-Member in question. These include:

a) Participation in specific activities opened by the Organisation to the participation of nonMembers, such as Global Forums and other outreach activities;

b) Participation directly in the official sessions of the subsidiary body as ad hoc observer, regular observer or full participant;

c) Any other form of co-operation that may appear appropriate.

\section{PARTICIPATION IN OFFICIAL SESSIONS OF SUBSIDIARY BODIES}

2. Committees may recommend to the Council to invite non-Members to participate in their work either as observers or full participants on the basis of a well-targeted pro-active outreach strategy as described in Annex I of the Resolution.

\section{$\underline{\text { Recommendations by Committees }}$}

3. Participation in official sessions of subsidiary bodies, whether as a regular observer or full participant, should be recommended sparingly.

4. Should a Committee recommend to Council to invite a non-Member to participate in its work or the work of one of its subsidiary bodies as a regular observer or full participant, the Committee should provide a detailed analysis which describes how the non-Member contributes to the realisation of the Committee's outreach strategy as provided in Annex I to this Resolution.

a) A subsidiary body may invite a non-Member to participate in a country policy review before transmitting its recommendation to the Council. Such a review should familiarise the nonMember with the frank and transparent dialogue of the OECD, assist in assessing its readiness for participation, and encourage desirable policy changes. The associated costs, or an appropriate part thereof, shall be covered by the non-Member concerned. 
C(2004)132/FINAL

b) Committees shall specify and justify in their recommendation whether the invitation should be valid for all or some of their subsidiary bodies. Prior consultation of their subsidiary bodies is left to the Committee's discretion.

\section{$\underline{\text { Terms of Observer Invitations }}$}

5. Observer invitations should continue to be the norm for non-Member participation in official sessions. Observers are generally invited and participate on the following basis:

a) Ad hoc invitations to attend as observer at one or more meetings, or relevant parts of meetings should be the first consideration in deciding the appropriate level of participation in a subsidiary body. Ad hoc observerships should be issued only for individual meetings, and only if so required by specific items on the meeting's agenda. Ad hoc observers are expected to contribute to the discussion. A non-Member may be invited as an ad hoc observer for such purposes as preliminary policy exchange or country review, or an exploration of the nature of the non-Member's expected contribution to the work of the subsidiary body.

b) "Regular observers" receive an invitation to attend the meetings of a subsidiary body, on the understanding that they will actively participate and fully co-operate in the work of the subsidiary body, including information exchanges. This is subject to the conditions set in the Rules of Procedure, in this Resolution and in the invitation. Invitations are generally issued for a period of two years and should relate to the requirements of the Committee's mandate and programme of work. These invitations can be extended by the Council for further periods also generally of a two-year length. However, the Council reserves the right to suspend an invitation at any time for non-payment of fees due by the non-Member or for any other reason that the Council deems justified.

c) A regular observer shall make an appropriate financial contribution to the expenses of the Organisation.

d) Acceptance of relevant disciplines may be made a condition for regular observership.

e) Unless otherwise specified, an invitation to participate as a regular observer in the work of a subsidiary body does not include meetings of that body at Ministerial level or meetings of its subsidiary bodies or joint meetings with other bodies.

\section{Terms of Full Participant Invitations}

6. Full participation is generally accorded only to a non-Member which is willing and able to comply with the relevant disciplines of the Organisation, and if full participation would provide greater mutual benefit than observership. Full participation is generally granted on the following basis:

a) It is subject to binding agreements concluded with invited full participants, pursuant to Rule $8 \mathrm{a})$ of the Rules of Procedure. These provide the non-Member's adherence to all OECD instruments forming a basis of the subsidiary body's work and generally accepted by the Members; obligate the non-Member to co-operate fully in the work of the subsidiary body, including information exchanges; and commit it to contribute appropriately to the expenses of 
the Organisation. These agreements are for an indefinite duration and subject to suspension or termination by the OECD on reasonable notice.

b) Full participants are invited to attend all meetings of the subsidiary body to which the invitation relates, including joint meetings with other Committees and meetings at ministerial level, except as provided in paragraph 8 below.

c) Full participation is not envisaged for the Council and the bodies assisting it in the governance of the Organisation or for the Executive Committee in Special Session.

d) If a subsidiary body has a variety of activities, not all of which are appropriate for full participation by non-Members, the invitation should be limited to specified activities. If necessary, the subsidiary body should consider reorganising its work pattern so that the invitation will not impinge inappropriately on its work.

e) Full participation can also be granted in the framework of the negotiation of an OECD instrument or a specific project. In these cases, the invitation is extended only for the duration of the negotiation or the project.

\section{$\underline{\text { Modalities of Participation of Observers and Full Participants }}$}

7. Observers participate in the work of the subsidiary body as provided in the Rules of procedure, in the Resolution and in the invitation.

a) Observers are notified of the dates of meetings or parts of meetings they may attend and provided with the agenda, summary records and documents thereof.

b) The Chair of the Council is empowered to decide that particular meetings (or parts of meetings), shall be held without observer attendance. In so doing, he may make appropriate distinctions, e.g., between governmental observers and those from international organisations. In such cases, meetings, or specific agenda items, are marked as "closed" or "confidential". When parts of a meeting are closed, the agenda should be arranged to minimise the inconvenience for the observers. Chairs and Secretariats of subsidiary bodies will inform the Chair of the Council promptly of a situation calling for an exercise of this power. They shall also bear in mind any general decisions which the Chair of the Council has issued under this rule.

c) Observers are invited to make statements on a particular subject at the discretion of the subsidiary body chair. This discretion is exercised to maximise the mutual benefits of the nonMember's participation. Observers are given a seat at the table, where Member countries' needs permit. They do not take part in the decision-making process nor can they place a question on the agenda. An observer is not bound by the conclusions, proposals or decisions of the body in question unless it expressly agrees.

8. Full participants take part in the meetings and work of the subsidiary body to which their invitation applies on the same basis as Member countries, except as otherwise provided in their invitation. They are however not invited to meetings, or parts of meetings, held in the context of the accession of a non-Member to the Organisation, and may also be excluded from those concerning the relations of the Organisation with non-Members. In such cases, the provisions in paragraph 7b) above shall be applicable mutatis mutandis. 